UNIVERSIDADE DE SÃO PAULO

INSTITUTO DE GEOCIENCIAS

\title{
FACIOLOGIA, PROVENIÊNCIA E PALEOGEOGRAFIA DAS FORMAÇÕES PIRAMBÓIA E BOTUCATU NO ESTADO DO PARANÁ
}

Leandro Menezes Donatti

Orientador: Prof. Dr. Paulo César Fonseca Giannini

DISSERTAÇÃO DE MESTRADO

Programa de Pós-Graduação em Geologia Sedimentar

SÃO PAULO

2002 


\section{UNIVERSIDADE DE SÃO PAULO \\ INSTITUTO DE GEOCIENNCIAS}

\section{FACIOLOGIA, PROVENIÊNCIA E PALEOGEOGRAFIA DAS FORMAÇÕES PIRAMBÓIA E BOTUCATU NO ESTADO DO PARANÁ}

\section{LEANDRO MENEZES DONATTI}

Orientador: Prof. Dr. Paulo César Fonseca Giannini

DISSERTAÇÃO DE MESTRADO

COMISSÃO JULGADORA

Nome

Presidente: Prof. Dr. Paulo César Fonseca Giannini

Examinadores: Prof. Dr. Claudio Riccomini

Prof. Dr. Mario Luis Assine
Assinatura

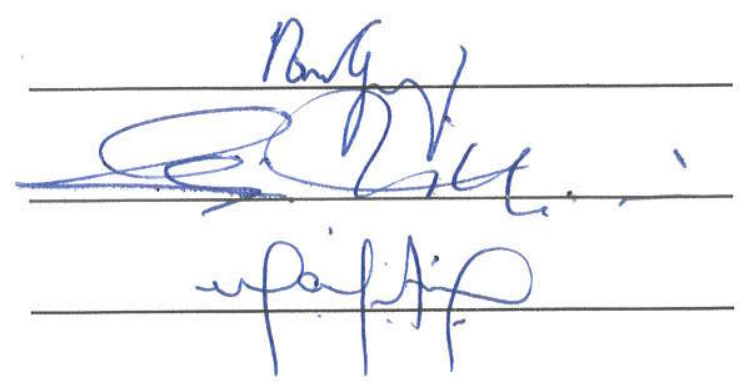

SÃO PAULO

2002 
UNIVERSIDADE DE SÃO PAULO

INSTITUTO DE GEOCIÊNCIAS

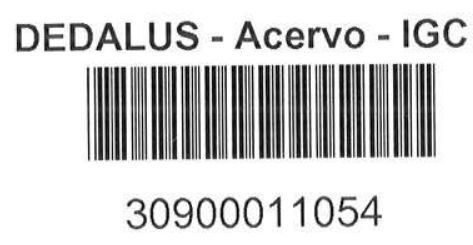

\section{FACIOLOGIA, PROVENIÊNCIA E PALEOGEOGRAFIA DAS FORMAÇÕES PIRAMBÓIA E BOTUCATU NO ESTADO DO PARANÁ}

Leandro Menezes Donatti

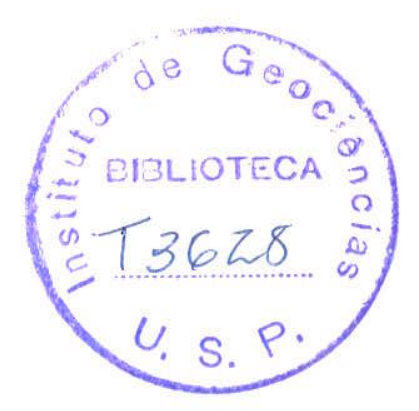

Orientador: Prof. Dr. Paulo César Fonseca Giannini

$$
\text { DISSERTAÇÃO DE MESTRADO }
$$

Programa de Pós-Graduação em Geologia Sedimentar

SÃO PAULO

2002 
A Deus pai todo-poderoso

Aos avós que partiram, Guilherme, Maria Tereza e Hernani (in memoriam) 
"A ciência jamais pôde entender o irracional, e portanto, não tem futuro diante de si neste mundo."

(Wilde, O. "Aforismos")

"Uma ciência que tem certezas absolutas sobre cenários tão imaginativos... não é uma ciência, mas uma crença!".

(Giannini 2001)". 


\section{AGRADECIMENTOS}

Agradeço a Deus, que nunca me abandonou em minha caminhada, colocando tantas pessoas importantes em minha vida. Pessoas que souberam, cada uma a seu modo, mostrar-me o caminho do bem e do conhecimento.

Por isso devo também minha eterna gratidão àqueles que de uma forma ou de outra me auxiliaram nesta pesquisa, companheiros ou companheiras desta jornada: em especial à minha companheira, Anne, a quem dedico esta dissertação. Minha maior motivadora, que com ternura e amor encurtou a distância entre São Paulo e Curitiba.

Agradeço à família, minha mãe Heluiza, meu pai Antonio Lino e meu irmão Diego além de meus "nonos" Guilherme Donatti (In memorian) e llda Zen Donatti, tão próximos...

Aos professores doutores Armando Márcio Coimbra (in memoriam) e Paulo César Fonseca Giannini (orientador). Os incentivadores que apostaram em $\mathrm{mim}$, permitindo que participasse de sua equipe de pesquisa. Agradeço em especial a meu orientador, que aprendi a admirar desde 1993, seja pela força de trabalho e honestidade, seja pela paciência e respeito com que trata a todos.

Agradeço aos amigos, e cúmplices, Afonso Nogueira, Alexei Kerkis, Renata Hidalgo (ao Júlio também) e ao André Ferrari, que me ajudaram a vencer as dificuldades e as saudades de casa.

Ao Hélcio dos Prazeres $\mathrm{F}^{\circ}$, Gilberto Kaulfuss e Werner Weber, que me auxiliaram nos primeiros dias de São Paulo, cedendo um espaço na república da esperança.

Sou grato ao Reynaldo Peña Castellón pela gentileza e amizade com que me acolheu na convivência de sua vizinhança nestes quase três anos.

Agradeço também ao eng ${ }^{\circ}$ Isaac Sayeg e aos professores doutores Luiz Alberto Fernandes e Daniel Atencio, que participaram ativamente do processo de pesquisa científica, engrandecendo-o. E foram além, dosando ciência com amizade.

Agradeço, ainda, aos professores doutores Setembrino Petri, Kenitiro Suguio, Cláudio Riccomini e Della Fávera pelos cursos proferidos durante o processo de créditos do mestrado, e ao Prof. Dr. Jorge Hachiro pelo empréstimo de bibliografia.

A Magali Fernandes Rizzo, Ana Paula Cabanal e Tadeu Caggiano pelo apoio e paciência nos assuntos da pós-graduação. A Flávio Carvalho pelas análises de raios $x$. Ao frutinha, André Oliveira Sawakuchi, companheiro de calorosas discussões em campo

Aos companheiros do dia-a-dia, que trouxeram motivação em inúmeros momentos: Eva Kaiser Mori, Caroline Thaís Martinho, Renata Naves de Oliveira, Karin Camilo, Camila Michelin, Maria Paula Valadares, Andréia Assato, Andreza Kenez, Marília de Castro, Paula Amaral, Elaine Sinfrônio, Alexandre Feitosa, Ivo Trosdtorf Jr., George de Barros, Alexandre Tomio, Rogério Ribeiro, Denise Daleva Costa, Liliane Janikian, Renato Paes de Almeida, Renato Ghilardi, Carlos César Araújo, Ana Paula Pelosi, Gelson Fambrini, Cynthia Helena Pinheiro, Douglas Vivona, Daniela Ferraz de Toledo, Marcelus Glaucus, Sérgio Fabris de Mattos.

Sou grato também a bibliotecária Marlene (Mineropar), à Suderhsa, à Sanepar, à Sema, pelos dados. Ao IPT, pela infra-estrutura e conhecimentos fornecidos para a confecção de impregnação de amostras.

Agradeço à Fapesp pelo auxilio financeiro fornecido através do processo de bolsa de mestrado n̊99/00984-1, que tornou viável o desenvolvimento deste projeto. 
Muito obrigado também aos amigos do centro de computação eletrônica CCE - USP, que não puderam participar diretamente na elaboração desta dissertação, mas que ajudaram em minha formação.

E como não lembrar do relator da Fapesp? Mesmo anônimo, participou deste projeto com inúmeras sugestões e questionamentos, permitindo aperfeiçoá-lo. Obrigado! 


\section{SUMÁRIO}

LISTA DE TABELAS

ix

LISTA DE QUADROS

LISTA DE FIGURAS-

1. INTRODUÇÃO $-1$

1.1. BACIA DO PARANÁ: SÍNTESE DO CONHECIMENTO

1.3. METAS

1.4. OBJETIVOS

2. MATERIAIS E MÉTODOS 4

2.1. PESQUISA BIBLIOGRÁFICA

2.2. ATIVIDADES DE CAMPO

2.2.1. ESCOLHA DE ÁREAS PARA DETALHAMENTO

2.2.2. MEDIDAS DE ATITUDES DE ESTRATIFICAÇÕES CRUZADAS E SUPERFÍCIES DE TRUNCAMENTO $-9$

2.2.3. REALIIZAÇÃO DAS SEÇÕES 9

2.2.4. AMOSTRAGEM 10

2.2.5. ANÁLISE DE FÁCIES $-10$

2.2.6. SUPERFICIES DE TRUNCAMENTO E SUPERSUPERFICIES

2.3.1. LABORATORIOS E INSTITUIÇŐES ENVOLVIDAS

2.3.2. GRANULOMETRIA $-15$

2.3.3 SEPARAÇÃO DE MINERAIS PESADOS

2.3.4. SEPARAÇÃO AO IMÃ MANUAL-_- 15

2.3.5.2. LÂMINAS DE GRÃOS

2.4. PETROGRAFIA E MEV/EED

2.4.1. ANÁLISE PETROGRÁFICA

2.4.2. CONTAGEM DE MINERAIS PESADOS

2.5. TRATAMENTO DOS RESULTADOS OBTIDOS $-18$

2.5.1. TRATAMENTO DOS RESULTADOS DE CAMPO

2.5.2. CONFECÇÃO DE ROSÁCEAS DOS AZIMUTES DE MERGULHO-_. 19

2.5.3. ANÁLISE DOS ÂNGULOS DE MERGULHO COM BASE EM PARÂMETROS ESTATIŚSTICOS - - - 20

2.5.4. ANÁLISE DOS DADOS OBTIDOS EM LABORATÓRIO

3.2.1. CONTATO BASAL DA FORMAÇÃO PIRAMBÓIA 
3.2.2. A PASSAGEM PIRAMBÓIA - BOTUCATU

3.2.3. SOLEIRAS E DERRAMES ASSOCIADOS Ã FORMAÇÃO SERRA GERAL

3.3. SEDIMENTOLOGIA DAS FORMAÇÓES PIRAMBÓIA E BOTUCATU

3.3.1. PALEOCORRENTES-

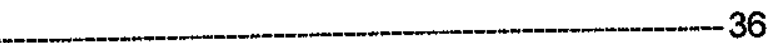

3.4.1. CORRELAÇÃO LITOESTRATIGRÁFICA E DATAÇÃO RELATIVA

3.4.2. GEOCRONOLOGIA -- 38

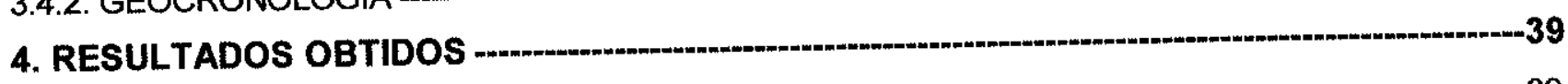

4.1. INTRODUÇÃO

4.2. ANÁLISE DE FÁCIES -

4.3. MODELO GENÉTICO INTEGRADO

4.3.1. ASSOCIAÇŐES DE FÁCIES -

4.3.2. TIPOS DE SISTEMAS DEPOSICIONAIS -

4.4. CRITÉRIOS DE DISTINÇÃO ENTRE OS SISTEMAS PIRAMBOIA E BOTUCATU

4.5. FATORES REGULADORES DA DINÂMICA DOS SISTEMAS PIRAMBÓIA E BOTUCATU -

4.6. SUPERFÍCIES DE TRUNCAMENTO

4.7. AZIMUTES DE MERGULHO DE ESTRATIFICAÇŐES CRUZADAS

4.8. ÂNGULOS DE MERGULHO DE ESTRATIFICAÇÕES CRUZADAS

4.10. SEPARAÇÃO DENSIMÉTRICA E MAGNÉTICA-

4.11. DESCRIÇÃO E QUANTIFICAÇÃO DE MINERAIS PESADOS

4.13. MICROANÁLISE PONTUAL AO MEV/EED

4.14. APRESENTAÇÃO DAS SEÇÕES GEOLOGGICAS

5. CONCLUSÕES

REFERÊNCIAS BIBLIOGRÁFICAS -

\section{ANEXOS}

An 1. Tabela 01 - Localização, em coordenadas UTM, dos pontos de afloramento descritos e a nomenclatura atribuída às amostras

An 2. Seção geológica ao longo da Rodovia PR - 431. Trecho entre Jacarezinho e Ribeirão Claro, PR

An 3. Seção geológica ao longo da Rodovia BR - 153. Trecho sul das folhas topográficas Cambará e Jacarezinho, PR

An 4. Seção geológica ao longo das Rodovias $B R-153$ e $P R-439$. Trecho entre Ribeirão do Pinhal e Santo Antônio da Platina, PR

An 5. Seção geológica ao longo da Rodovia BR - 376. Trecho entre Mauá da Serra e Ortigueira, PR

An 6. Seção geológica ao longo da Rodovia $B R$ - 466. Trecho entre Pitanga e Ivaiporã, $P R$

An 7. Seção geológica ao longo de rodovia entre Manuel Ribas e Cândido de Abreu, PR 
An 8. Seção geológica ao longo das Rodovias $B R-373$ e BR - 277. Trecho entre Guarapuava e Prudentópolis, PR

An 9. Seção geológica ao longo da Rodovia PR - 280. Trecho entre Porto União (SC) / União da Vitória (PR)

An 10 Legenda das seções colunares compostas, elaboradas nas regiões de Piraju - Sarutaiá, SP, Santo Antônio da Platina, PR.

An 11 Seções colunares compostas, elaboradas nas regiões de Piraju - Sarutaiá, SP, e Santo Antônio da Platina, PR 


\section{LISTA DE TABELAS}

Tabela 02 - Parâmetros de distribuição de freqüências de ângulos de mergulho de estratificações cruzadas do sistema Pirambóia no Paraná

Tabela 03 - Parâmetros de distribuição de frequêencias de ângulos de mergulho de estratificações cruzadas do sistema Botucatu, no Paraná

Tabela 04 - Resultados de ensaio de separação densimétrica na fração areia muito fina e de separação magnética na fração pesada (arenito Rio do Rasto) 91

Tabela 05 - Resultados de ensaio de separação densimétrica na fração areia muito fina e de separação magnética na fração pesada (arenito Pirambóia)

Tabela 06 - Resultados de ensaio de separação densimétrica na fração areia muito fina e de separação magnética na fração pesada (arenitos Botucatu e intertrapp)

Tabela 07 - Resultados de quantificaçăo de minerais pesados $(d>2,85)$ ao microscópio petrográfico (arenito Rio do Rasto)

Tabela 08 - Resultados de quantificação de minerais pesados $(d>2,85)$

ao microscópio petrográfico (arenito Pirambóia)

Tabela 09 - Resultados de quantificação de minerais pesados $(d>2,85)$ ao microscópio petrográfico (arenitos Botucatu e intertrapp)

Tabela 10 - Ordem sugerida para os processos diagenéticos que atuaram no sistema Pirambóia104

Tabela 11 - Ordem sugerida para os processos diagenéticos que atuaram no sistema Botucatu, incluindo arenitos intertrapp. 


\section{LISTA DE QUADROS}

Quadro 01 - Códigos utilizados para designação de pontos de estudo e amostragem, segundo sua localização nas folhas topográficas disponiveis. 6

Quadro 02 - Evolução dos conhecimentos da Formação Pirambóia (Modificado de Sgarbi 1997). ----- 34

Quadro 03 - Sumário de fácies sedimentares dos sistemas eólicos Pirambóia e Botucatu no Paraná. 60

Quadro 04 - Critérios de campo para distinção entre os depósitos dos sistemas deposicionais eólicos úmido (Pirambóia) e seco (Botucatu).

Quadro 05 - Rumos de paleoventos interpretados para a metade inferior do sistema Pirambóia. 67

Quadro 06 - Rumos de paleoventos interpretados para a metade superior do sistema Pirambóia. 68

Quadro 07 - Paleocorrentes fluviais interpretadas para a metade superior do sistema Pirambóia. 68

Quadro 08 - Rumos de paleoventos interpretados para a metade inferior do sistema Botucatu. 69

Quadro 09 - Rumos de paleoventos interpretados para a metade superior do sistema Botucatu. 69

Quadro 10 - Rumos de paleoventos interpretados para a metade superior do sistema Botucatu, pertencente à Formação Serra Geral. 


\section{LISTA DE FIGURAS}

Figura 01 - Localização da Bacia do Paraná no continente sul-americano -

Figura 02 - Mapa geológico simplificado da Bacia do Paraná, com a distribuição, no tempo, das diversas unidades de seu registro sedimentar

Figura 03 - Contexto geotectônico fanerozóico da margem Sul do Gondwana e sítio de convergência com o assoalho oceânico do Panthalassa 2

Figura 04 - Mapa geológico do Paraná (fonte mapa - base: Mineropar 1986) 8

Figura 05 - Arcabouço conceitual das superfícies de truncamento

Figura 06 - Diagrama cronolitoestratigráfico da Bacia do Paraná

Figura 07 - Arenito muito fino com estratificação cruzada plano-paralela 40

Figura 08 - Arenito fino sob lamito arenoso esverdeado

Figura 09 - Arenito fino sobre lamito arenoso esverdeado

Figura 10 - Estratificação cruzada acanalada com superfícies de truncamento de $3^{\natural}$ ordem que se sucedem em intervalos submétricos

Figura 11 - Série de espessura métrica, cuneiforme, de estratificações cruzadas tangenciais na base e no topo (seta), sigmóides, de alto ângulo de mergulho

Figura 12 - Convolução suave (seta) em arenito fino da fácies Acbl

Figura 13 - Lamito com laminação muito fina (base da foto) recoberto por arenito fino com estratificação plano-paralela

Figura 14 - Arenito fino com intraclastos tablóides a angulosos

Figura 15 - Arenito fino com clastos de lamito subarredondados a angulosos (setas), tablóides a esferoidais, preenchendo estrutura de corte em arenito-

Figura 16 - Arenito médio a grosso com seixos e grânulos de quartzo e quartzito acompanhando as laminaçőes cruzadas planares

Figura 17 - Arenito grosso conglomerático, com seixos e grânulos de quartzo e quartzito, subangulosos

Figura 18 - Intercalação de niveis aparentemente lenticulares de arenito grosso a arenito muito grosso, conglomerático

Figura 19 - Laminação heterolítica deformada alternando arenitos médios a grossos com siltitos de coloração roxa

Figura 20 - Arenito com estratificação cruzada tangencial na base, de alto ângulo de mergulho, maior que $15^{\circ}$, com alternáncia entre lentes de queda e fluxo de grãos

Figura 21 - Arenito com estratificação cruzada acanalada de alto ângulo de mergulho

Figura 22 - Arenito fino com estratificação cruzada acanalada de baixo ângulo de mergulho e laminação plano-paralela

Figura 23 - Marcas onduladas cavalgantes subcríticas (ponta da lapiseira) ou transladantes (seta) 
Figura 24 - Marcas onduladas assimétricas aplainadas, de crista reta sobre plano de estratificação cruzada acanalada com ângulo baixo

Figura 25 - Lajes de arenito silicificado exibindo, em planta, as marcas onduladas de crista reta da foto anterior. Pedreira em Ribeirão Claro PR

Figura 26 - Arenito médio a fino com estratificação cruzada acanalada de alto ângulo de mergulho, com deformação penecontemporânea a sedimentação -----m- 53

Figura 27 - Dobras enterolíticas, em silexito (seta), em meio a lamito (roxo) do Grupo Passa Dois na região norte do Paraná, município de Santo António da Platina.

Figura 28 - Nódulos silicificados (seta) possivelmente gerados em condições eogenéticas evaporíticas, em lamito (roxo) do Grupo Passa Dois

Figura 29 - Arenito fino a médio com fragmento de rocha ígnea, de coloração escura, interpretada como de origem piroclástica

Figura 30 - Area de afloramento das formações Pirambóia e Botucatu no Estado do Paraná, com diagramas em rosa e direçס̃es de paleoventos e de paleocorrentes subaquosas 74

Figura 31 - Área de afloramento das formaçőes Pirambóia e Botucatu no Estado do Paraná, com diagramas em rosa e direçőes de paleoventos e de paleocorrentes subaquosas -- - 75

Figura 32 - Área de afloramento das formaçőes Pirambóia e Botucatu no Estado do Paraná, com diagramas em rosa e direções de paleoventos-

Figura 33 - Área de afloramento das formações Pirambóia e Botucatu no Estado do Paraná, com diagramas em rosa e direções de paleoventos

Figura 34 - Área de afloramento das formações Pirambóia e Botucatu no Estado do Paraná, com diagramas em rosa e direçő́es de paleoventos

Figura 35 - Parâmetros estatísticos construídos a partir das medidas de ângulos de mergulho de estratificações cruzadas dos sistemas eólicos Pirambóia e Botucatu

Figura 36 - Valores do desvio padrão obtidos a partir das medidas de azimutes de mergulho de estratificaçőes cruzadas das fácies Aca, ACc, ACg e Afca

Figura 37 - Gráfico representativo da relação fino/grosso confeccionado com valores de máximo e mínimo para cada fatia estratigráfica

Figura 38 - Gráfico representativo dos valores médios da relação fino/grosso, de acordo com as diferentes fatias estratigráficas

Figura 39 - Gráfico da proporção percentual de areia muito grossa confeccionado a partir dos valores de máximo e mínimo de cada fatia estratigráfica

Figura 40 - Gráfico de proporção percentual média da fração areia muito grossa confeccionado de acordo com as fatias estratigráficas

Figura 41 - Gráfico da proporção percentual de areia grossa confeccionado a partir dos valores de máximo e mínimo de cada fatia estratigráfica

Figura 42 - Gráfico de proporção percentual média da fração areia grossa confeccionado de acordo com as fatias estratigráficas 
Figura 43 - Gráfico da proporção percentual de areia média confeccionado a partir dos valores máximo e mínimo de cada fatia estratigráfica

Figura 44 - Gráfico de proporção percentual média da fração areia média confeccionado de acordo com as fatias estratigráficas

Figura 45 - Gráfico da proporção percentual de areia fina confeccionado a partir dos valores máximo e mínimo de cada fatia estratigráfica 86

Figura 46 - Gráfico de proporção percentual média da fração areia fina confeccionado de acordo com as fatias estratigráficas

Figura 47 - Gráfico da proporção percentual de areia muito fina, confeccionado a partir de valores de máximo e mínimo de cada fatia estratigráfica 86

Figura 48 - Gráfico de proporção percentual média da fração areia muito fina, confeccionado de acordo com as fatias estratigráficas

Figura 49 - Gráfico da proporção percentual de argila, confeccionado a partir dos valores máximo e mínimo de cada fatia estratigráfica

Figura 50 - Gráfico de proporção percentual média da fração argila confeccionado de acordo com as fatias estratigráficas

Figura 51 - Gráfico de amplitude do parâmetro diâmetro médio nas diferentes fatias estratigráficas

Figura 52 - Gráfico de amplitude do parâmetro desvio padrão da distribuição de freqüências da fração areia nas diferentes fatias estratigráficas $-87$

Figura 53 - Gráfico de amplitude do parâmetro assimetria da distribuição de freqüências da fração areia nas diferentes fatias estratigráficas

Figura 54 - Gráfico de amplitude do parâmetro curtose da distribuição de freqüências da fração areia nas diferentes fatias estratigráficas.

Figura 55 - Gráfico de amplitude do parâmetro diâmetro médio da distribuição de freqüências da fração total nas diferentes fatias estratigráficas

Figura 56 - Gráfico de amplitude do parâmetro desvio padrão da distribuição de freqüências da fração total nas diferentes fatias estratigráficas

Figura 57 - Gráfico de amplitude do parâmetro curtose da distribuição de freqüências da fração total nas diferentes fatias estratigráficas

Figura 58 - Gráfico de amplitude do parâmetro assimetria da distribuição de freqüências da fração total nas diferentes fatias estratigráficas

Figura 59 - Grăo de apatita arredondado, com formas superficiais poligonais (amostra JC.10pi, Pirambóia inferior, região norte do Paraná) 96

Figura 60 - Grão de estaurolita, subédrico, da amostra JC.03v 96

Figura 61 - Grão de estaurolita denteado pertencente à metade inferior do Botucatu, região norte do Paraná (amostra JC.12a)

Figura 62 - Granada euédrica de amostra da metade inferior do Botucatu, região norte do Paraná

Figura 63 - Grãos arredondados de turmalina (dravita), opacos e epídoto da metade inferior do Botucatu (Amostra JC.12a, região norte do Paraná) 96 
Figura. 64 - Grăos de zircão, bipiramidado e com inclusões (direita), turmalina (centro- esquerda), estaurolita (esquerda) e quartzo, da metade superior do Botucatu (amostra IP.01, região norte do Paraná) -

Figura 65 - Cianita com denteamento, observada em amostra da metade superior do Botucatu, da região norte do Paraná (Amostra SA.03cb - grão de areia muito fina)

Figura 66 - Grão de apatita arredondado, de amostra da metade superior da Botucatu, região norte do Paraná (grão de areia muito fina - amostra SA.03cb) ‥__ 97

Figura 67 - Grãos de feldspato com geminação em grade e Carlsbad

Figura 68 - Aspecto fibro-radiado de argilomineral em contato com grão de quartzo. Amostra JC.07c (Jacarezinho), da metade superior do sistema Botucatu

Figura 69 - Característica da cimentação por argilominerais (esmectita/caulinita) de grãos de quartzo (Amostra JC.07c metade superior do sistema Botucatu, região norte do Paraná)

Figura 70 - Fragmento lítico de silexito, formado por calcedônia fibrosa (nicóis descruzados, acima à esquerda, e nicóis cruzados, abaixo à direita) 105

Figura 71 - Grão de mineral opaco, parcialmente destruído, interpretado como fonte potencial de óxido/hidróxido de ferro para cutículas que recobrem grãos de quartzo do arcabouço 106

Figura 72 - Dissolução em grão de feldspato. Amostra da metade inferior (JC.11) do sistema Pirambóia na região norte do Paraná

Figura 73 - Grão composto de quartzo do arcabouço (fragmento lítico de quartzito) de amostra da metade inferior (JC.11) do sistema Pirambóia na regiâo norte do Paraná -- 106

Figura 74 - Relações de cimentação em amostra, da metade inferior (JC.11) do sistema Pirambóia na região norte do Paraná

Figura 75 - Grãos de quartzo do arcabouço, e de mineral pesado (ao centro), com franja de argilomineral (provável esmectita) impregnante à superfície dos grãos

Figura 76 - Visão geral dos grãos de quartzo do arcabouço em nicóis cruzados, e de argilominerais (provável esmectita) que envolvem os grãos de quartzo

Figura 77 - Argilomineral preenchendo porosidade secundária (círculo) e grấos de quartzo angulosos mal selecionados

Figura 78 - Detalhe de porosidade móldica e agigantada, isolando grãos do arcabouço (cluster) ----- 108

Figura 79 - Aspecto textural "sujo" de grăos de arenitos feldspáticos da metade superior do sistema Pirambóia na região centro-sul do Paraná.

Figura 80 - Detalhe de porosidade móldica, com resquícios do material original orientado, possivelmente de grãos de feldspato do arcabouço.

Figura 81 - Grãos de quartzo cimentados por óxido/hidróxido de ferro de amostra da porção superior do sistema Pirambóia na regiấo centro-norte do Paraná (amostra IV.05).

Figura 82 - Grão de quartzo recoberto por argilomineral (amostra MS.12a do topo da Formação Pirambóia, imediatamente abaixo do contato com a Formaçăo Botucatu, região centro-norte do Paraná)

Figura 83 - Cristálitos placoidais, em detalhe, interpretados como caulinita (autigena?) 
Figura 84 - Detalhe da figura anterior. Notar a presença de argilomineral desmantelado, interpretado como produto de alteração de feldspato

Figura 85 - Detalhe dos cristálitos placoidais sobre grão de quartzo com feições triangulares

Figura 86 - Feições poligonizadas, sobre superfícies de truncamento de $3^{a}$ ordem

Figura 87 - Visão em pequeno detalhe de cimento impregnante dos grăos do arcabouço

Figura 88 - Detalhe do cimento de sílica impregnante dos grãos do arcabouço

Figura 89 - Maior detalhe do cimento de sílica impregnante dos grãos do arcabouço

Figura 90 - Maior detalhe do cimento de sílica impregnante

Figura 91 - Aspecto em maior detalhe dos meniscos de sílica da fotomicrografia anterior, atribuídos a processos de remobilização e reprecipitação de $\mathrm{SiO}_{2}$

Figura 92 - Aspecto fibro-radiado de argilomineral (provável paligorskita)

Figura 93 - Outro aspecto das fibras da foto

Figura 94 - Mineral interpretado como caulinita autígena, desmantelada por telodiagênese

Figura 95 - Aspecto pé-de-couve de provável esmectita

Figura 96 - Agregado placoidal, com aspecto típico de acordeon, de caulinita autígena 119

Figura 97 - Microfeições de corrosão química em feldspato 


\section{RESUMO}

Através da análise de fácies dos arenitos das formações Pirambóia, Botucatu e Serra Geral nos estados do Paraná e extremo sul paulista (Piraju), subdividiram-se os depósitos estudados em quatro associações faciológicas com posicionamento estratigráfico distinto. Da base para o topo, estas associações correspondem a: A) lençóis de areia em planície de maré, B) campo de dunas costeiro com planícies interdunares inundadas, C) planície aluvial com rios entrelaçados e dunas eólicas incipientes e D) campo de dunas seco. As três primeiras associações caracterizam o registro de um sistema deposicional eólico úmido (isto é, cujo nível freático esteve próximo à superfície), o sistema deposicional eólico úmido Pirambóia. O nível freático elevado neste sistema pode ser atribuído à proximidade da paleocosta. A quarta associação de fácies, de campo de dunas seco, sobrepõemse abruptamente aos depósitos flúvio-eólicos do sistema Pirambóia e corresponde ao sistema deposicional eólico seco Botucatu. O contraste entre os sistemas eólicos Pirambóia (úmido) e Botucatu (seco) é um critério importante para definir a inconformidade regional que separa os depósitos destes dois sistemas eólicos. O sistema seco teria sido interrompido por uma superfície de extensão regional, bacinal, ligada à manifestação do vulcanismo Serra Geral.

Os resultados granulométricos confirmam a fácies de arenito grosso a conglomerático $(\mathrm{ACg})$ como traço marcante da metade superior do registro do sistema Pirambóia. Os resultados de petrografia, MEV/EED e contagem de minerais pesados caracterizam a tendência para maior maturidade química e grau de cimentação dos arenitos Botucatu. A abundância de cimento de esmectita nos arenitos dos dois sistemas pode ser considerada um indício de ambiente de diagênese precoce com pouca água em circulação. Óxidos de ferro associados, principalmente no sistema Botucatu, apontam para cimentação na zona de aeração, portanto em condições de paleolençol freático baixo. A presença de paligorskita em fácies subaquosas do topo dos arenitos Pirambóia indica que condições evaporíticas já imperavam no final do sistema eólico úmido. As condições tectônicas, entretanto, não teriam permanecido constantes, perdendo, na instalação do sistema Botucatu, o grau de atividade demonstrando no desfecho do sistema Pirambóia.

A distribuição geográfica das fácies e dos vetores modais de azimute de estratificações cruzadas eólicas permite interpretar a existência de dois influxos no sistema Pirambóia, um continental, proveniente de Norte, e outro, costeiro, de Sul. A convergência dos rumos de paleoventos poderia estar associada à existência de um paleoalto na região do lineamento de Guapiara. Já o sistema Botucatu teria sido dominado por influxo voltado para SW e SE, com aumento de dispersão no topo. 


\section{ABSTRACT}

The sandstones of the succession Pirambóia - Botucatu - Serra Geral (PaleozoicMesozoic Paraná Basin, southeastern Brazil), in the Paraná State, was subdivided into four facies associations. From the base for the top, these associations correspond to: A) Sand sheets on tidal plain, B) Coastal dunefields with flooded interdunes, C) Alluvial plain with braided rivers and small eolian dunes, and D) Dry dunefields. The first three associations record a wet eolian depositional system (that is, a system whose freatic level was close to the surface), the Pirambóia system. The high freatic level in this system can be attributed to the proximity of the paleocoast. The fourth fácies association, of dry dunefields, is put abruptly upon to the Pirambóia fluvio-eolian deposits. It corresponds to the Botucatu dry eolian depositional system. The contrast between the Pirambóia (wet) and Botucatu (dry) eolian systems is an important criterion to define the regional unconformity that separates the sandstones of these two systems. The dry system would have been interrupted by a surface of bacinal extension, associated with the manifestation of the Serra Geral vulcanism.

The grain-size results confirm the coarse to conglomeratic sandstone facies $(\mathrm{ACg})$ as the main feature of the superior half of the Pirambóia system. The petrografic, SEM/EDS and heavy minerals results characterize the tendence for greater chemical maturity and cementation degree of the Botucatu sandstones. The abundance of smectite cement in the sandstones of the two systems is an indication of eodiagenesis with scarcy circulating water. Iron oxides, present mainly in the Botucatu sandstones, can be related to cementation in the vadose zone, therefore in conditions of low freatic level. The paligorskite presence in subaqueous facies of the top of the Pirambóia sandstones indicates that evaporitic conditions were already present in the end of the wet eolian system. The tectonic conditions would not have stayed constant, losing, in the installation of the system Botucatu, the activity degree demonstrated in the ending of the Pirambóia system.

The geographical distribution of the facies and of the modal dip directions of eolian cross-beddings allow to interpret the existence of two eolian influxes in the Pirambóia system, a continental influx, from North, and a coastal one, from South. The convergence of these paleowind directions could be associated with the existence of a high area along the Guapiara alignment. The Botucatu system would have been dominated by influx towards SW and SE, with increasing dispersion to the top. 


\section{INTRODUÇÃO}

\subsection{Bacia do Paraná: síntese do conhecimento}

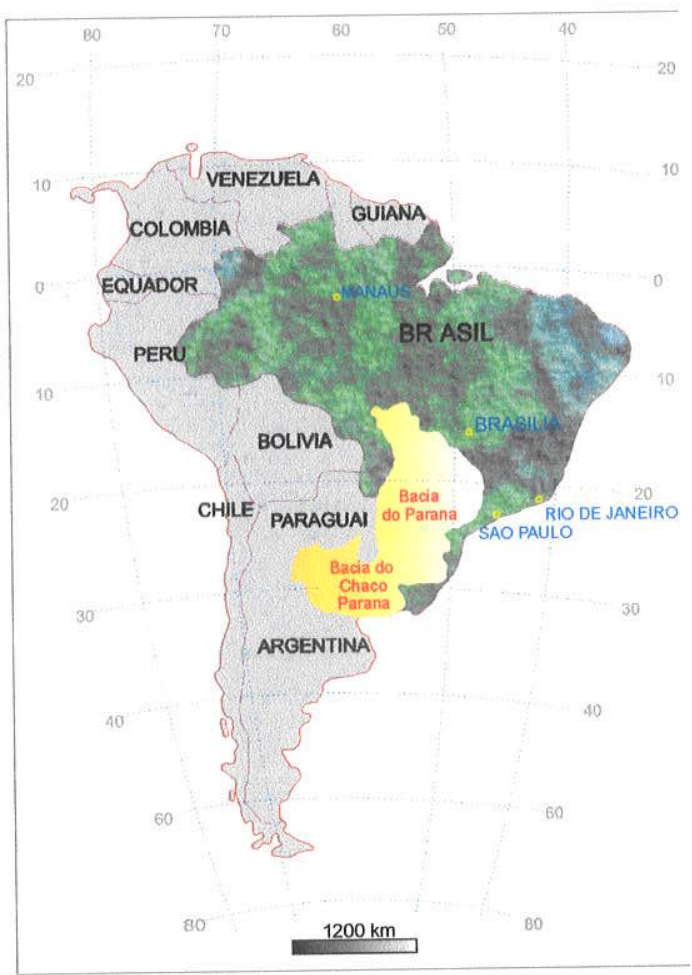

Figura 01 - Localização da Bacia do Paraná no continente sul-americano (figura confeccionada por Alexei Kerkis).
A Bacia do Paraná é uma vasta bacia cratônica, desenvolvida completamente sobre crosta continental, e preenchida por rochas sedimentares e vulcânicas, com idades que variam do Siluriano ao Cretáceo. Abrange uma área de cerca de 1.700 .000 $\mathrm{km}^{2}$, estendendo-se pelo Brasil meridional $\left(1.100 .000 \mathrm{~km}^{2}\right)$, Paraguai $\left(100.000 \mathrm{~km}^{2}\right)$, Uruguai $\left(100.000 \mathrm{~km}^{2}\right)$ e Argentina (400.000 $\mathrm{km}^{2}$ ). Possui formato alongado na direção NNE-SSW ( $1.750 \mathrm{~km}$ de comprimento), com largura média de $900 \mathrm{~km}$. Dois terços da porção brasileira da bacia $\left(734.000 \mathrm{~km}^{2}\right)$ são cobertos por derrames de lava. A espessura máxima da bacia atinge cerca de $7.000 \mathrm{~m}$ no seu depocentro. Seu nome provém do rio Paraná, que corre paralelo ao eixo maior da bacia, em direção NE-SW, por cerca de 1.500

$\mathrm{km}$, até defletir em direção E-W, onde o rio cruza o arco de Assunção, e define a fronteira do Brasil com o Paraguai e a Argentina (Almeida 1953; Soares 1973; Soares 1992; Schneider 1974; Zalán et al. 1991).

A evolução da Bacia do Paraná é amplamente discutida na literatura geológica desde White (1908). Mesmo as tentativas mais recentes de aplicar as técnicas advindas da sismoestratigrafia (Milani 1997), e por extensão, os conceitos que dela derivam, como a estratigrafia de seqüências, não foram capazes de resolver algumas das questões mais polêmicas a respeito da bacia. 


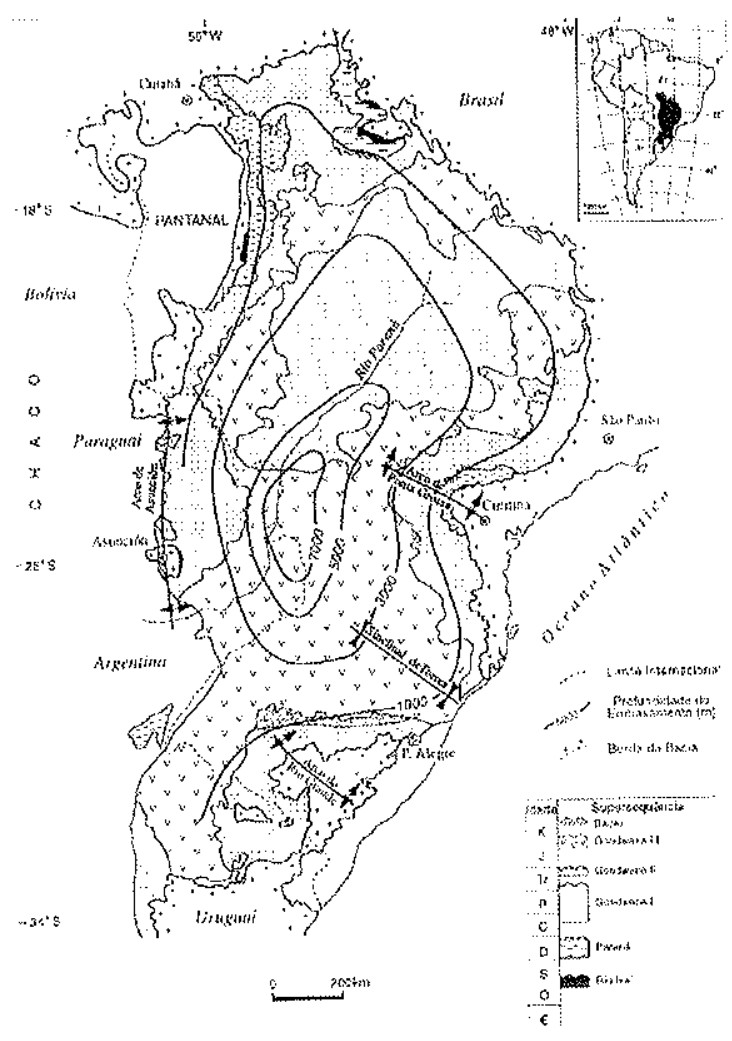

Figura 02 - Mapa geológico simplificado da Bacia do Paraná, com a distribuição, no tempo, das diversas unidades de seu registro sedimentar (Milani 1998).

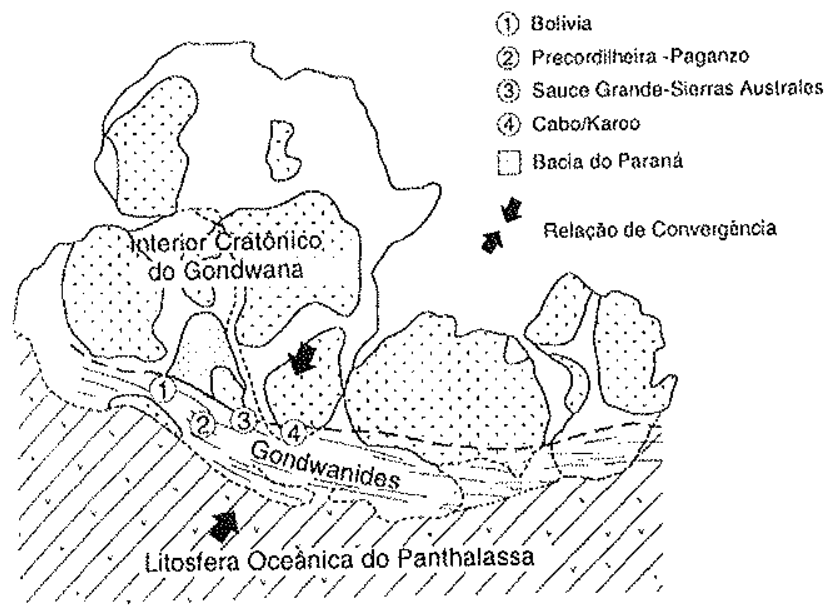

Figura 03 - Contexto geotectônico fanerozóico da margem Sul do Gondwana e sítio de convergência com o assoalho oceânico do Panthalassa (Milani 1998).

Os 400 milhões de anos distribuídos em cerca de $7.000 \mathrm{~m}$ de espessura de registro sedimentar são, ainda, pouco estudados, se comparar-se, por exemplo, a quantidade de afloramentos descritos e dados de poços perfurados com a área aflorante do registro sedimentar.

O arcabouço evolutivo da Bacia do Paraná aponta para um desenvolvimento movido por transgressões e regressões marinhas (Schneider 1974; Lavina 1991; Soares 1992; Rohn 1994; Milani 1997), condicionado por movimentos de crescimento da litosfera continental (substrato), ao longo da margem Sul do Gondwana, em um contexto de fechamento progressivo do interior do continente (Della Fávera 1990; Lavina 1991; Milani 1997). Os ciclos de trangressão-regressão teriam iniciado há cerca de 450M.a., no 
Ordovicio-Siluriano, seguido por sequêencias ou ciclos no Devoniano, no PermoCarbonífero. Em seguida desenvolveram-se os ciclos, de caráter continental, regressivos, no Permo-Triássico, Juro-Cretáceo e Cretáceo. A bacia teria se comportado como um golfo aberto para o Panthalassa pelo menos até o Carbonífero (Figura 03), originando com o tempo uma depressão interna ao cráton, aprisionada no interior do Gondwana, designada como Lago Mar no Eopermiano até o Cretáceo (Della Fávera 1990; Lavina 1991; Rohn 1994).

O objeto de estudo desta Dissertação é detalhar parte das Superseqüências Gondwânicas de Milani (1997, 1998), ou o que o denomina de pacotes sedimentares continentais mesozóicos com rochas ígneas associadas.

\subsection{A relevância do tema}

Abordam-se aqui algumas das questões mais polêmicas sobre as formações Pirambóia e Botucatu, Mesozóico da Bacia do Paraná, principalmente dentro dos limites políticos do Estado do Paraná, com base em revisão aprofundada da bibliografia disponivel.

No sentido de enumerar algumas daquelas questões polêmicas, destacam-se: o intervalo de tempo envolvido, a idade das duas formações, os critérios para diferenciálas, a caracterização dos seus contatos com outras unidades e a indicação de áreas fontes prováveis.

Neste estudo, as respostas a essas questões são voltadas ao esboço da paleogeografia, da faciologia e da proveniência dos arenitos das formações Pirambóia e Botucatu no Paraná. Planejou-se o detalhamento da estratigrafia e da faciologia através da realização de seções geológicas em quatro áreas selecionadas, através da coleta de amostras destinadas a estudos petrográficos, texturais e mineralógicos, incluindo o exame de microtexturas deposicionais e diagenéticas ao Microscópio Eletrônico de Varredura (MEV) e Espectrômetro de Energia Dispersiva (EED).

Para cada um dos questionamentos sobre as formações Pirambóia - Botucatu, existem inúmeras implicações de interesse tanto acadêmico quanto aplicado que podem fornecer novos rumos ao estudo e exploração econômica das duas unidades. No âmbito acadêmico, destacam-se o estabelecimento mais seguro da coluna litoestratigráfica do Grupo São Bento e de seu arcabouço no contexto de estratigrafia de seqüências e a 
melhor compreensão do panorama dos grandes desertos que parecem ter dominado a paisagem das bacias Paraná e Bauru a partir do final do Permiano.

Em relação à geologia exploratória, a década de 90 marca o despertar da comunidade geológica brasileira e internacional para as Formações Botucatu e Pirambóia enquanto aqǘfero gigante do Mercosul, que em conjunto com formações correlatas, aflorante nos países vizinhos, compõem uma das maiores reservas de água subterrânea do planeta (Giusti et al. 1996; Rosa $\mathrm{F}^{\circ}$ et al. 1996).

Cabe destacar também o uso dos arenitos do Grupo São Bento como matéria prima para construção civil e para indústrias de vidro, cerâmica e fundição, e do potencial destes arenitos como rocha reservatório, no momento em que se revigora a exploração e pesquisa de hidrocarbonetos no país.

\subsection{Metas}

As metas desta dissertação respondem à pergunta sobre até onde se pretende chegar. Incluem portanto as propostas mais pretensiosas do estudo. Nesse sentido, a meta mais geral é a de aprofundar o conhecimento da geologia do Grupo São Bento, Bacia do Paraná, em seu domínio aflorante no Estado do Paraná. Como metas mais específicas, destacam-se:

1. Compreender a evolução paleogeográfica da bacia, durante o intervalo de tempo correspondente à sedimentação das formações Pirambóia e Botucatu.

2. Identificar assinaturas texturais, mineralógicas e petrográficas para as principais fácies e horizontes estratigráficos reconhecidos.

3. Analisar e comparar as formações Pirambóia e Botucatu sob a perspectiva de seus sistemas deposicionais, com especial interesse em uma melhor compreensão da passagem entre as duas unidades.

4. Aplicar conceitos de estratigrafia de seqüências em sistemas deposicionais eólicos, no contexto do arcabouço conceitual proposto por Kocurek \& Havholm (1993).

\subsection{Objetivos}

Os objetivos respondem à questão sobre o que se planejou executar. Propôs-se uma lista de quatro tarefas principais: 
1. Revisão da bibliografia disponivel sobre as formações sedimentares do Grupo São Bento.

2. Descrição, classificação e interpretação genética das rochas presentes na passagem entre as formações Pirambóia e Botucatu.

3. Levantamento de seções geológicas detalhadas em regiões previamente selecionadas de afloramento dos arenitos Pirambóia e Botucatu no Estado do Paraná (norte, em Jacarezinho-Santo Antônio da Platina, centro-norte em Ivaiporä-Mauá da Serra, centro-sul em Guarapuava-Prudentópolis e sul, em União da Vitória-Porto União).

4. Caracterização textural, mineralógica e diagenética de fácies e/ou horizontes estratigráficos com representatividade regional.

\section{MATERIAIS E MÉTODOS}

\subsection{Pesquisa bibliográfica}

Foram analisadas publicações disponiveis nas bibliotecas do Instituto de Geociências da Universidade de São Paulo (USP) e do Centro Politécnico da Universidade Federal do Paraná (UFPR), além de relatórios internos de companhias e secretarias: Companhia Paranaense de Energia Elétrica (COPEL), Companhia de Saneamento do Paraná (SANEPAR), Instituto Ambiental do Paraná (IAP), Serviço Geológico do Paraná (MINEROPAR), Companhia de Pesquisa e Recursos Minerais (CPRM), Consórcio CESP/IPT (Paulipetro), Secretaria de Estado de Meio Ambiente e de Recursos Hídricos (SEMA) do Paraná.

A sistemática adotada para o levantamento bibliográfico foi desenvolvida com a consulta de verbetes (formações Botucatu e Pirambóia, Grupo São Bento, Formação Serra Geral) em publicações mais recentes e em arquivos digitais (i.e. sistema de bibliotecas da USP, SiBi, ou da American Geologic Institute, GeoRef). Alguns autores clássicos foram encontrados na análise por autor, no fichário das bibliotecas. Nesse sentido, a análise das referências bibliográficas listadas em Giannini (1993) definiu o ponto inicial, para que se pudesse reconhecer os autores com maior número de 
publicações, e/ou mais intimamente relacionados aos temas e métodos propostos na pesquisa.

\subsection{Atividades de campo}

Foram realizados levantamentos em quatro áreas no Estado do Paraná (norte, centro-norte, centro-sul e sul) e Piraju - Sarutaiá, no extremo sul do Estado de São Paulo, cujo empilhamento, estratigráfico, foi levantado em cortes de rodovias e pedreiras com condições mais satisfatórias de afloramento, geralmente associadas à frente de escarpas. Os pontos de descrição e amostragem foram codificados com siglas relativas às folhas topográficas (letras do nome das folhas em negrito), de acordo com o Quadro 01:

\begin{tabular}{|l|c|c|c|c|}
\hline \multicolumn{1}{|c|}{ Folha topográfica } & Fonte & Escala & Estado & $\begin{array}{c}\text { Código de } \\
\text { amostras }\end{array}$ \\
\hline Sarutaiá & IBGE & $1: 50.000$ & $\mathrm{SP}$ & $\mathrm{SR}$ \\
\hline Piraju & IBGE & $1: 50.000$ & $\mathrm{SP}$ & $\mathrm{PI}$ \\
\hline Cambará & IBGE & $1: 50.000$ & $\mathrm{PR}$ & $\mathrm{CA}$ \\
\hline Cândido de Abreu & EXÉRCITO & $1: 100.000$ & $\mathrm{PR}$ & $\mathrm{CB}$ \\
\hline Guarapuava & IBGE & $1: 100.000$ & $\mathrm{PR}$ & $\mathrm{GR}$ \\
\hline Ipauçu & IBGE & $1: 50.000$ & $\mathrm{PR} / \mathrm{SP}$ & $\mathrm{IP}$ \\
\hline Ireneópolis & IBGE & $1: 100.000$ & $\mathrm{PR}$ & $\mathrm{IR}$ \\
\hline Ivaiporã & EXÉRCITO & $1: 100.000$ & $\mathrm{PR}$ & $\mathrm{IV}$ \\
\hline Jacarezinho & IBGE & $1: 50.000$ & $\mathrm{PR}$ & $\mathrm{JC}$ \\
\hline Joaquim Távora & IBGE & $1: 50.000$ & $\mathrm{PR}$ & $\mathrm{JT}$ \\
\hline Mauá da Serra & IBGE & $1: 50.000$ & $\mathrm{PR}$ & $\mathrm{MS}$ \\
\hline Pitanga & EXÉRCITO & $1: 100.000$ & $\mathrm{PR}$ & $\mathrm{PT}$ \\
\hline Ribeirão do Pinhal & IBGE & $1: 50.000$ & $\mathrm{PR}$ & $\mathrm{RP}$ \\
\hline Santo Antônio da Platina & IBGE & $1: 50.000$ & $\mathrm{PR}$ & $\mathrm{SA}$ \\
\hline União da Vitória & IBGE & $1: 100.000$ & $\mathrm{PR} / \mathrm{SC}$ & $\mathrm{UV}$ \\
\hline
\end{tabular}

Quadro 01 - Códigos utilizados para designação de pontos de estudo e amostragem, segundo sua localização nas folhas topográficas disponíveis.

Para a obtenção das coordenadas, foi empregado aparelho GPS. Com estas coordenadas, os pontos de estudo foram anotados em cartas topográficas 1:50.000 ou 1:100.000 obtidas no IBGE - Instituto Brasileiro de Geografia e Estatística e no Ministério do Exército, Divisão de Cartografia. 


\subsubsection{Escolha de áreas para detalhamento}

A definição das áreas para detalhamento foi determinada pelos fatores:

1. Exposição

2. Qualidade dos afloramentos

3. Facilidade de acesso

4. Sobreposição com áreas-tipo, definidas na bibliografia.

Devido ao prazo relativamente curto para desenvolver a pesquisa de Mestrado, 0 tempo foi considerado como um quinto fator.

A qualidade dos afloramentos foi relacionada principalmente à condição de cobertura por vegetação e/ou depósito de tálus. Dentro do critério exposição, foi considerado prioritariamente o tamanho do corte. A escolha das áreas teve, pela questão tempo, de ser conjugada com o requisito facilidade de acesso. Em termos práticos, isto significou limitar a descrição a cortes de rodovias e ferrovias principais. O último critério, de sobreposição, foi relacionado a escolha de afloramentos "clássicos" descritos em publicações disponiveis no momento da realização das jornadas de campo. A título de exemplo, pode-se citar os trabalhos de Soares (1973), que realizou levantamentos na serra da Esperança (próximo a Guarapuava, PR), e de Riccomini et al. (1984), que mapearam a serra do Cadeado (próximo a Cândido de Abreu, PR). 


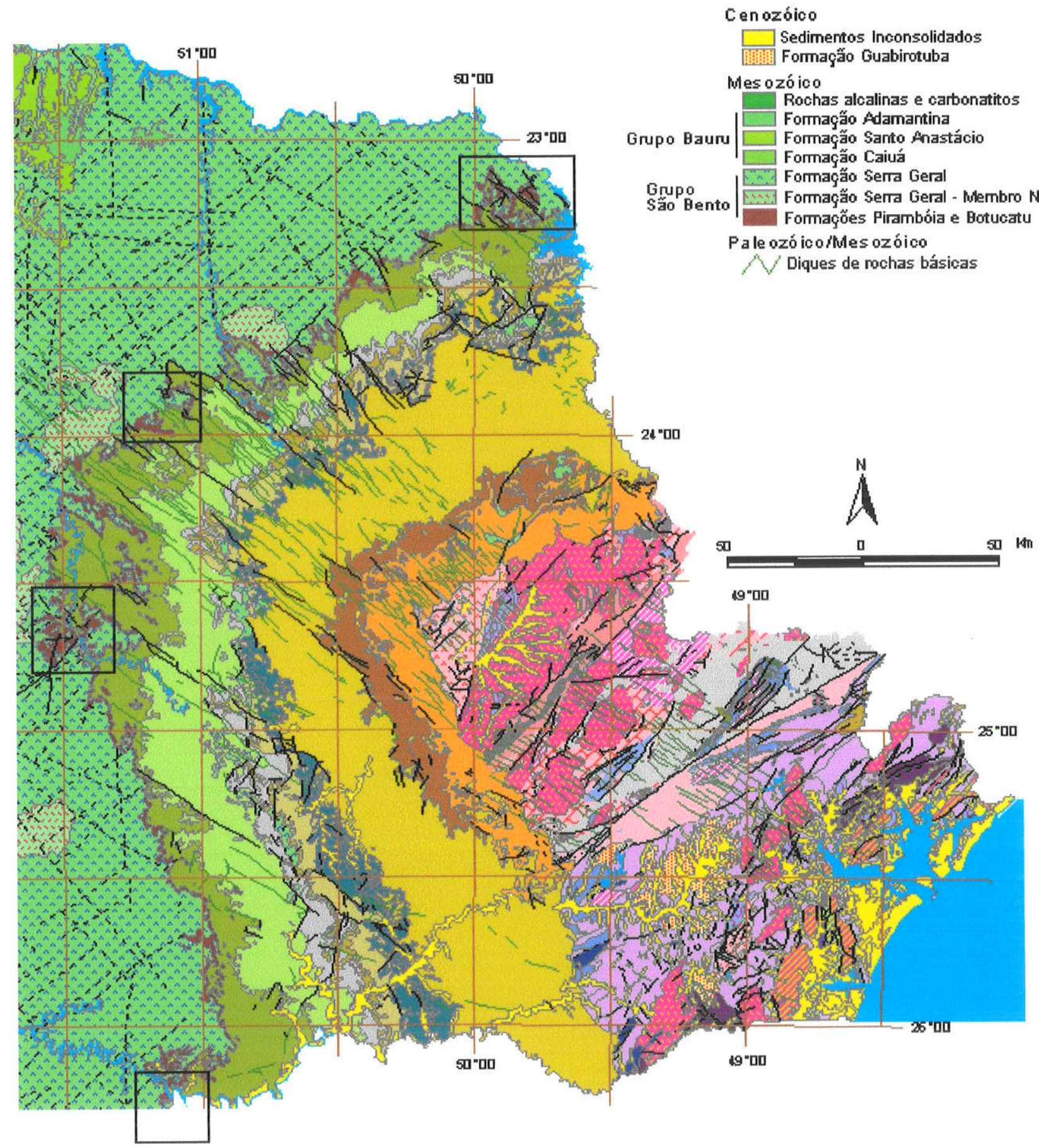

Figura 04 - Mapa geológico do Paraná, com localização (quadros em destaque) das áreas onde foram realizadas as seções geológicas detalhadas: no norte, Jacarezinho, no centro-norte, Mauá da Serra, no centro-sul, Guarapuava e no sul, União da Vitória. Na legenda, canto superior direito, destacam-se somente as rochas Mesozóicas e Cenozóicas (fonte mapa - base: Mineropar 1986, cedido em forma digital pelo Prof. Dr. L. A. Fernandes). 
2.2.2. Medidas de atitudes de estratificações cruzadas e superficies de truncamento

A obtenção de medidas de rumo de mergulho de estratificações cruzadas foi realizada com bússolas do tipo Clar e Brunton. Teve como base os conceitos descritos por Fernandes (1992, 1998), que associa um significado geológico, de acordo com a ordem de cada série de cruzadas, tanto maior em termos de ordem quanto maior o tamanho das séries. Desse modo, utilizando a classificação estratonômica de McKee (1953), séries com altura maior que $3 \mathrm{~m}$ seriam consideradas de primeira ordem, séries entre $3 \mathrm{~m}$ e $0,3 \mathrm{~m}$, de segunda ordem e séries menores que $0,3 \mathrm{~m}$, de terceira ordem (ver item 2.5.2).

Buscou-se aprimorar tal método, com a identificação da posição vertical em que se realizou a medida, em relação à base e ao topo da série. No sistema de notação adotado, os valores negativos representam a distância da medida em relação ao topo da série de cruzadas e o valor positivo, a distância em relação à base. Uma medida que apresente, por exemplo, valores +1 e $-2 \mathrm{~m}$ indica a espessura de $3 \mathrm{~m}$ entre os planos de truncamento (limites da série). Contudo, como o uso de trena nem sempre foi possível, muitas medidas constituem valores estimados. Com a disponibilidade destes dados, agrega-se uma nova informação a cada medida de azimute de mergulho obtida. Neste estudo, modificou-se o método de Fernandes (1992; 1998), substituindo-se a classificação de McKee (1953) pela hierarquia genética das estratificações, baseada na classificação estratonômica de Campbell (1967) (lâmina, pequeno porte, série de lâminas, médio porte, e série de camadas, grande porte). Para os limites de série, considerou-se, sempre que possível, a hierarquia de truncamento conforme a conceituação de Kocurek (1981, 1988, 1996).

\subsubsection{Realização das seções}

Durante o levantamento das seçōes, as principais atividades realizadas foram: locação de pontos com aparelho GPS; análise de fácies, pelo método de Walker (1976) modificado por Anderton (1985), e de horizontes estratigráficos, com confecção de seções colunares; análise geométrica de estratificações cruzadas de médio e grande porte e superfícies delimitantes de séries e co-séries, com ênfase para a relação espacial com niveis rudáceos e lutáceos e a identificação de superfícies de truncamento segundo conceitos de Kocurek $(1981,1988,1993)$ e Fryberger (1993); documentação fotográfica 
detalhada de afloramentos e de feições de relevo mais importantes dos afloramentos; coleta sistemática de amostras por fácies e/ou horizonte e medição das atitudes de estratificações cruzadas.

Ao final das etapas de campo, contabilizaram-se 56 amostras friáveis e 10 amostras silicificadas distribuídas em 98 afloramentos descritos, mais de 300 fotografias e diapositivos, e 803 medidas de estratificações cruzadas.

\subsubsection{Amostragem}

Procedeu-se uma coleta sistemática de amostras, que foram nominadas de acordo com o código do ponto de coleta. A sigla adotada foi aquela correspondente à folha topográfica. Ao lado do número de cada amostra, indicou-se com as letras minúsculas c e $h$, se a fácies amostrada continha estratificações cruzadas de ângulo acentuado $\left(<15^{\circ}\right)$ ou baixo, respectivamente, na tentativa de organizar as amostras por critérios genéticos.

A lista de pontos de amostragem e de medida de rumo de mergulho de estratificações cruzadas encontra-se anexa (Tabela 01), com a localização dos pontos em notação UTM.

\subsubsection{Análise de fácies}

Procurou-se fazer a análise de fácies segundo uma abordagem que atendesse a princípios sistêmicos. Isto equivale à satisfação de dois requisitos enunciados por Giannini (1993). O primeiro deles é ter em vista a produção de modelos falsificáveis, através de raciocínios processo-resposta, conforme idealizado por Fichter (1988). A característica principal destes modelos de fácies é a sua capacidade permanente de fazer predições, cuja verificação no campo ou via testes laboratoriais e estatísticos estimula novas observações e possiveis novos modelos. O segundo pré-requisito citado por Giannini (1993) é a ênfase às inter-relações entre fácies, de acordo com o princípio essencial da teoria de sistemas: as propriedades e modos de ação dos niveis superiores não se podem explicar pela soma das propriedades e modos de ação que correspondem a seus componentes isoladamente; apesar disto, é possivel chegar aos niveis mais elevados partindo dos componentes menores, quando se conhece o conjunto de componentes e suas inter-relações (Bertalanffy 1952 apud Bertalanffy 1972).

O método de análise de fácies adotado neste trabalho é basicamente uma versão da proposta de Anderton (1985) modificada de Walker (1976). Ele inicia-se por uma fase 
preliminar de levantamento cartográfico e bibliográfico da área, com estabelecimento tentativo de associações de fácies e sistemas deposicionais hipotéticos. As fases posteriores começam pelo trabalho de campo e podem ser assim enumeradas: (1) descrição detalhada do afloramento ou feição geomorfológica; (2) subdivisão em fácies descritivas; (3) compilação das características de cada fácies (modelos descritivos); (4) dedução dos processos deposicionais de cada fácies (modelos genéticos); (5) exame das relações espaciais entre fácies e reconhecimento de associações faciológicas (modelo descritivo integrado); (6) interpretação do ambiente da associação (modelo genético integrado); (7) modelagem final das fácies individuais; (8) teste de consistência via predição: retorno à fase (1) ou à fase (5), e assim sucessivamente. O conceito de modelo de fácies de Anderton (1985) é versátil, e este método, especialmente a partir da fase 3 , pode ser aplicado tanto na escala de um afloramento, como a um conjunto deles ou a toda área/bacia estudada. Desse modo, o exercício de zoom, dado pela alternância de pequenas e grandes escalas de modelagem em sucessivos testes de consistência (Coimbra \& Giannini 1989; Della Fávera 1991), é compativel com o método.

Anderton (1985) enfatiza que uma inversão na ordem das etapas conduz a risco de erros. Assim, conforme destaca Giannini (1993), a interpretação genética de uma fácies isolada, antes da descrição de fácies vizinhas de mesmo contexto sedimentar, tende a ser muito mais ambígua que a interpretação das várias fácies já descritas como um conjunto coerente. Este aspecto, de outro modo já destacado por Walker (1976), ressalta a importância do reconhecimento de associações de fácies (Giannini 1993). Cabe destacar a ressalva de Walker, com base nas leis de correlações de fácies de Walther. Ele discute que se o contato entre duas fácies for gradacional, então eles representam processos que ocorrem pelo menos uma vez lado a lado, mas, caso haja contatos abruptos ou do tipo erosivo, não há como identificar se os processos foram ou não adjacentes.

\subsubsection{Superfícies de truncamento e supersuperfícies}

As superfícies de truncamento no sistema eólico são formadas pela migração de formas de leito eólicas ou pela instalação de periodos de deflação durante o desenvolvimento de campos de dunas. $A$ análise destas superfícies constitui importante ferramenta na descrição e interpretação da dinâmica e evolução de sistemas deposicionais eólicos. 
A introdução do conceito de superfície de truncamento e sua divisão em três hierarquias deve-se a Stokes (1968). No entanto, deve-se a Brookfield (1977) e Kocurek (1981a, 1981b, 1988, 1996) a concepção das superfícies de $1^{\mathrm{a}}, 2^{\mathrm{a}}$ e $3^{\mathrm{a}}$ ordem e supersuperfícies, no modo como elas são mais usualmente descritas hoje em dia (Figura05). Segundo Brookfield (1977), as características das três ordens de superfícies de truncamento podem ser resumidas do seguinte modo:

1. Superficies de $1^{\mathrm{a}}$ ordem: de grande extensão, cortam todas as demais estruturas eólicas. Sua origem é atribuída à passagem de megaformas de leito eólicas (draas) sobre uma área.

2. Superficies de $2^{\mathrm{a}}$ ordem: cortam superficies de $3^{\mathrm{a}}$ ordem e formam-se através da passagem de dunas sobre os draas.

3. Superfícies de $3^{a}$ ordem: são superficies menores formadas durante a migração de dunas, via reativação das faces de sotavento.

4. Supersuperficies: são superfícies que delimitam sucessões deposicionais eólicas, cuja ocorrência estende-se por quilômetros; truncam superficies inclinadas relacionadas à migração das formas de leito. Representam-se em afloramento com caráter diferenciado das demais, podendo ser correlatas a eventos bacinais (por exemplo transgressões marinhas). Apresentam-se sub-horizontais e separam estilos diferentes entre séries de cruzadas acima e abaixo (Kocurek 1996). 

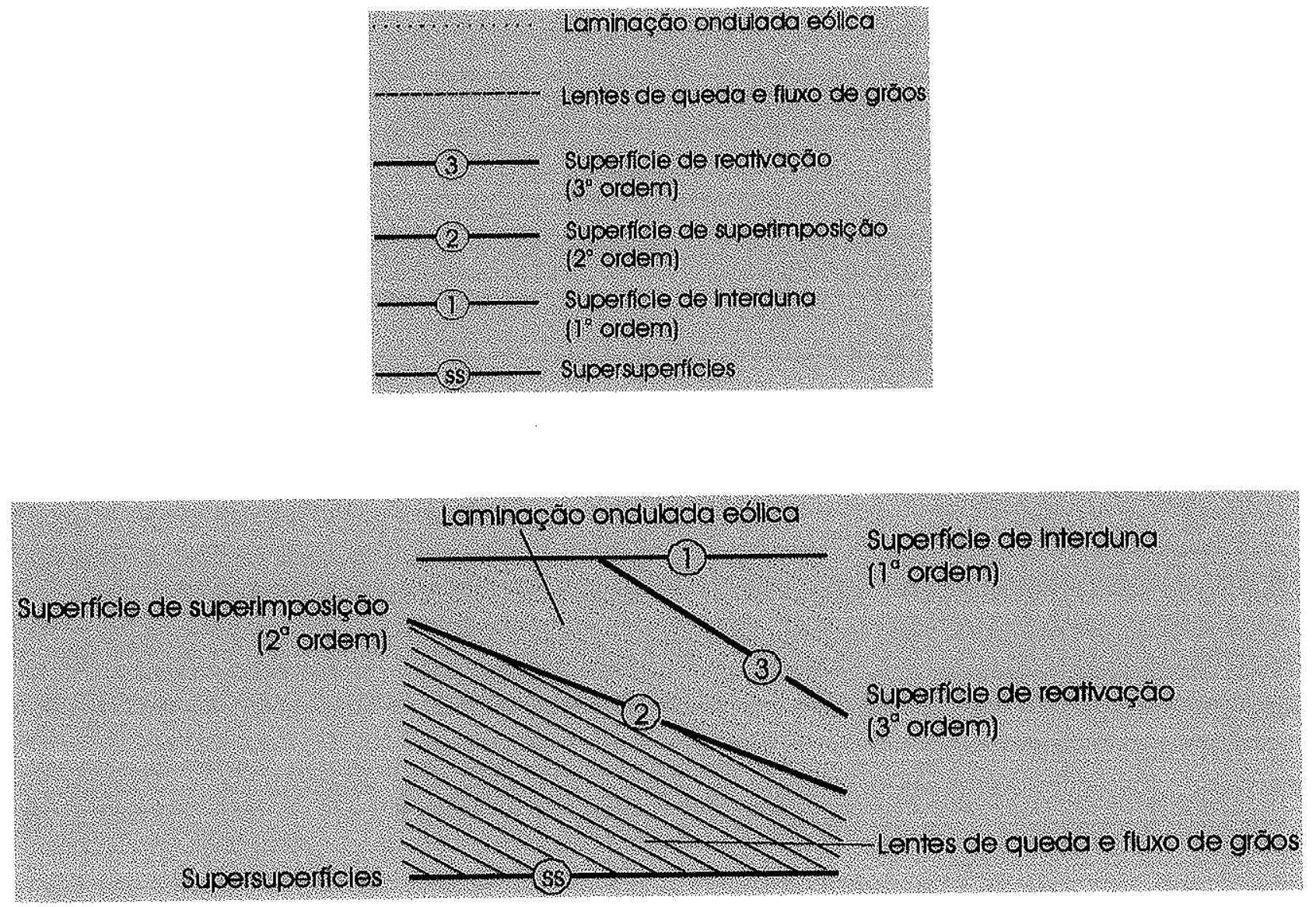

Figura 05 - Arcabouço conceitual das superficies de truncamento (Brookfield 1977; Kocurek 1996).

Kocurek $(1981,1988,1996)$ propôs alterações no modelo de Brookfield (1977). De acordo com sua proposta, as superfícies de $1^{\mathrm{a}}$ ordem podem formar-se também através da migração de interdunas sobre dunas (Figura 05). Neste caso, as superfícies de $1^{a}$ ordem não indicariam necessariamente a existência de draas, mas sim a ocorrência de cavalgamento seja de dunas, seja de draas (Carvalho \& Giannini 1998). Segundo Kocurek (1988), a existência de draas implica apenas a formação de superfícies de $2^{\mathrm{a}}$ ordem.

No campo, as três hierarquias de superfícies de truncamento segundo Kocurek (1988) podem ser identificadas através de sua mútua relação geométrica e espacial, bem como de suas relações com os estratos superiores e inferiores.

As superficies de $1^{a}$ e $2^{a}$ ordem assemelham-se entre si pelo baixo ângulo de mergulho. As superficies de $1^{a}$ ordem estendem-se por dezenas de metros a quilômetros, podendo cortar, mas nunca serem cortadas, por superfícies de $2^{\mathrm{a}}$ ordem. Analogamente, as superfícies de $2^{\mathrm{a}}$ ordem cortam as de $3^{\mathrm{a}}$, sem poderem ser cortadas por elas. Superficies de $2^{\mathrm{a}}$ e $3^{\mathrm{a}}$ ordem possuem dimensões métricas a decamétricas. Enquanto as 
superfícies de $3^{a}$ ordem discordam dos estratos abaixo e são recobertas concordantemente pelos estratos acima, as superfícies de $2^{a}$ ordem são discordantes dos estratos subjacentes, e sobrepostas discordantemente (isto é, em ângulo) pelos estratos sobrejacentes (Carvalho \& Giannini 1998; Sawakuchi 2000; Giannini 2001).

Por serem formadas por cavalgamento de megaformas, as superfícies de $1^{\text {a }}$ ordem são diácronas, mergulham preferencialmente para barlavento e ocorrem sobrepostas por estrato horizontal de fácies interdunares formado no decorrer de um intervalo de tempo. Em seção paralela à direção do vento, estas superfícies estendem-se por centenas de metros, cobertas por estratos horizontais lateralmente persistentes, confundindo-se, portanto, com as supersuperfícies (SS). Em seção perpendicular à direção do vento, as superfícies de $1^{a}$ ordem tendem a desaparecer lateralmente e os corpos de estratos horizontais sobrepostos adquirem geometria lenticular, enquanto as SS persistem lateralmente (Kocurek 1996).

\subsection{Atividades de laboratório}

A coleta sistemática de amostras destinou-se à confecçäo de seções delgadas, à caracterização textural-mineralógica de grãos (ensaios de granulometria, separação densimétrica e microscopia óptica de fração pesada) e a análises ao MEV/EED.

\subsubsection{Laboratórios e instituições envolvidos}

As análises foram executadas em cinco laboratórios do Departamento de Geologia Sedimentar e Ambiental (GSA) do Instituto de Geociências da Universidade de Săo Paulo (IG-USP): o Laboratório de Sedimentologia - Labsed (processo FAPESP 98/7959-0); 0 Laboratório de Petrografia Sedimentar - Labpetro (processo FAPESP 97/10669-0), 0 Laboratório de Microscopia Eletrônica de Varredura - Labmev (Processo FAPESP 95/5635-4), o Laboratório de Raios X e a Seção de Laminação de Rochas. Obteve-se, ainda, o auxílio do IPT (Instituto de Pesquisas Tecnológicas de São Paulo), através do Laboratório de Petrologia do Agrupamento de Engenharia de Rochas (A.E.R.), Divisão de Geologia, no sentido de desenvolver procedimentos de impregnação de amostras friáveis. 


\subsubsection{Granulometria}

As amostras que apresentavam condiçōes para serem mecanicamente desagregadas (total de 56 amostras friáveis) foram submetidas à análise granulométrica convencional (por pipetagem e peneiramento), seguindo os procedimentos indicados em Giannini (1993). A realização destes ensaios enquadrou-se no objetivo de caracterizar sedimentologicamente fácies e horizontes estratigráficos. Constituiu também uma etapa preliminar necessária à análise de minerais leves e pesados.

A fração inicial utilizada para análise foi de $50 \mathrm{~g}$, entretanto, percebeu-se que essa fração comprometia a concentração de minerais pesados pela escassez desses minerais, passando-se a utilizar $80 \mathrm{~g}$. O intervalo de pipetagem foi calculado seguindo a lei de Stokes, em temperatura constante $\left(20^{\circ} \mathrm{C}\right)$. Os intervalos de peneiramento empregados foram de $0,5 \varnothing(p h i)$, compreendidos entre $4 \varnothing(p h i)$ ou $0,062 \mathrm{~mm}$ (limite entre silte e areia na escala de Wentworth) e $-2 \varnothing$ (phi) ou $4 \mathrm{~mm}$ (limite entre grânulo e seixo na mesma escala).

\subsubsection{Separação de minerais pesados}

As amostras processadas no ensaio de granulometria foram submetidas a análise densimétrica por flutuação-afundamento em líquido denso (bromofórmio, $\mathrm{CHBr}_{3}, \mathrm{~d} 2,85$ $\mathrm{g} / \mathrm{cm}^{3}$ ), seguindo em linhas gerais procedimentos descritos por Parfenoff et al. (1970) e Carver (1971).

A separação de minerais pesados seguiu o critério adotado por Giannini (1993), que considera a existência de maior teor modal destes minerais deslocados para granulometrias mais finas, de até $1 \varnothing(p h i)$, em relação ao teor modal de minerais leves na amostra. Isso possibilitaria a quantificação, de modo representativo, dos minerais pesados de um único intervalo granulométrico de $1 \varnothing(p h i)$, desde que situado imediatamente acima (mais fino) do intervalo modal do sedimento.

\subsubsection{Separação ao imã portátil}

A separação de grãos magnéticos consistiu em atritar de maneira suave um imã, devidamente envolvido em saco plástico com espessura maior que $0,5 \mathrm{~mm}$, sobre a fração de minerais pesados previamente espalhada em superfície lisa. Nesse processo, alguns 
grãos não magnéticos aderem ao plástico, seja por deformação deste ou em resposta ao arraste mecânico. Para evitar esta presença indesejável de grãos não magnéticos, procurou-se ao final do ensaio espanar delicadamente os grãos atraídos com um pincel fino de cerda mole. Em seguida, retirou-se o imã do interior do saco plástico, liberando-se os minerais magnéticos para o recipiente destinado à pesagem em balança analítica (Giannini 1993; Giannini s.d.).

\subsubsection{Confecção de lâminas}

\subsubsection{Seções delgadas}

As amostras silicificadas foram diretamente submetidas, sem tratamento prévio, à confecção de lâminas delgadas com espessura de 30 um.

As amostras não silicificadas foram previamente impregnadas com resina colorida, com o intuito de permitir a diferenciação entre os poros originais e os poros induzidos pela posterior confecção das lâminas.

$\mathrm{Em}$ termos gerais, o procedimento de impregnação empregado consiste em elaborar uma mistura de reagentes químicos, composta por resina, endurecedor, corante e álcool, na proporção resina/endurecedor 10:1g, contendo, ainda, $14 \mathrm{~g}$ de álcool e $2 \mathrm{~g}$ de corante. As amostras previamente secas em estufas, são acondicionadas em câmara de vácuo, e a resina gotejada em recipiente próprio, contendo a amostra para impregnação.

\subsubsection{Lâminas de grãos}

As lâminas de grãos de minerais pesados foram confeccionadas através de cozimento em bálsamo do Canadá natural utilizando-se xileno, $\mathrm{C}_{6} \mathrm{H}_{4}\left(\mathrm{CH}_{8}\right)_{2}$, como solvente, para limpeza final das lâminas.

\subsection{Petrografia e MEVIEED}

A finalidade do estudo petrográfico foi confrontar as fácies e unidades litoestratigráficas distintas no campo com possiveis petrofácies estabelecidas por microscopia óptica, e avaliar a possibilidade de existência de contrastes de história diagenética entre amostras de diferentes unidades. Estes contrastes constituem critério 
potencial para a avaliação e delimitação de mudanças de ambiente sedimentar (eodiagenético) elou discordâncias.

Os estudos petrográficos serviram também para a seleção prévia das amostras e microfeições submetidas a detalhamento químico-textural no equipamento de MEV/EED. Estas análises foram realizadas preferencialmente em amostras situadas em posições estratigráficas consideradas chaves (base e/ou topo das unidades estudadas). Uma vez localizadas ao microscópio óptico, as microfeições de interesse foram assinaladas na própria lâmina descoberta, com uso de caneta para retroprojetor, ponta fina, para poderem ser facilmente encontradas.

\subsubsection{Análise petrográfica}

O estudo petrológico de cada amostra foi realizado em onze passos. A finalidade dessa organização em passos foi a de disciplinar as escalas e enfoques de exame da amostra. Desse modo, partiu-se da escala meso para a microscópica, do geral para o particular, das feições deposicionais para as diagenéticas, e dos aspectos descritivos para as interpretativos, seguindo proposta de Giannini (2001). De acordo com esta proposta, os onze passos seguidos foram:

1. Descrição mesoscópica sucinta, com destaque para cor, grau de alteração e estruturas sedimentares.

2. Estimativa modal percentual de componentes petrográficos deposicionais (arcabouço e matriz) e diagenéticos (cimento e porosidade secundária).

3. Descriçäo dos aspectos deposicionais do arcabouço, isto é, mineralogia, textura e petrotrama. No estudo da textura, procurou-se avaliar a granulação modal, o desvio padrão e o grau de seleção granulométricos de acordo com a tabela de estimativa visual de Pettijohn et al. (1972), e os parâmetros de forma (esfericidade e arredondamento) segundo a escala de Powers (1953). No estudo da petrotrama, atentou-se para orientação, imbricação e empacotamento, bem como para segregação granular gerada por diferenças de textura, mineralogia ou pelo arranjo espacial.

4. Descrição da matriz (proto e ortomatriz), incluindo mineralogia e textura, e identificação de matriz falsa (pseudo e epimatriz), seguindo critérios de Dott (1964) e Dickinson (1970). 
5. Descrição da mineralogia e textura do cimento, com indicação de possíveis gerações de cimentos.

6. Descrição de tipos de contato intergranular e de feiçōes de quebra ou deformação de grãos, e avaliação de seu significado enquanto indícios de compactação química e mecânica, respectivamente.

7. Descrição do tipo de porosidade secundária segundo a classificação de Choquette \& Pray (1971) e De Ros (1984).

8. Avaliação da maturidade mineralógica do arenito, segundo classificação de Folk (1974).

9. Avaliação da maturidade textural do arenito, segundo o critério triplo escalonado de Folk (1974).

10. Classificação petrográfica da rocha segundo Dott (1964) e Folk (1974).

11. Tentativa de interpretação do paleoclima e da paleotectônica, baseada nos critérios de Krynine (1948) e Dickinson \& Suczek (1979).

\subsubsection{Contagem de minerais pesados}

Os minerais pesados transparentes não micáceos foram quantificados até um total de pelo menos 100 grãos, utilizando-se o método da faixa (ribbon method de Galehouse 1971). Calculou-se o índice ZTR, somatório de minerais ultraestáveis (zircão, turmalina, rutilo) dentre grãos pesados transparentes não micáceos, de acordo com a definição original de Hubert (1962). De modo análogo, foram calculados índices somatórios de minerais metaestáveis (estaurolita, apatita, epídoto, cianita, sillimanita, granada), e de instáveis (olivina, piroxênios, anfibólios e andaluzita), adotando-se a classificação de estabilidade de minerais pesados de Pettijohn (1957).

\subsection{Tratamento dos resultados obtidos}

\subsubsection{Tratamento dos resultados de campo}

Durante as jornadas de campo, foram obtidas fotografias em câmeras convencionais de qualidade profissional. As fotografias foram utilizadas como ferramenta auxiliar na descrição e delimitação de fácies, na visualização de geometrias e na 
confecção de esquemas de campo. Parte das fotografias obtidas com a câmera convencional serviu para tratamento gráfico, através da técnica de cópia em papel vegetal sobreposto (overlay), para uso de montagens em papel e/ou de diapositivos projetados em tela branca. Esta técnica permitiu a melhor visualização das estruturas presentes e facilitou a análise das relações geométricas de estruturas e fácies.

As medidas de rumo de mergulho de superficies de truncamento e de planos de estratificação cruzada foram agrupadas por fácies ou camada e lançadas em gráficos de rosetas. O fator de consistência do azimute médio não possui significado absoluto em termos de confiabilidade estatística do resultado (um fator de consistência baixo, indicativo de alta dispersão de medidas, pode resultar de polimodalidade relacionada à geometria da megaforma de leito) e não leva em consideração o significado geológico de cada superfície medida (hierarquia na construção do depósito). Portanto, tentou-se utilizar o método de avaliação da confiabilidade de padrões de rosa de freqüências de Fernandes (1992, 1998). Este método atribui critérios de estatística clássica ao significado geológico da medida. Atribui assim um número mínimo ideal de medidas para cada ordem de grandeza espacial da estratificação. A classificação empregada para estas ordens de grandeza foi baseada em Campbell (1967). Os dados de rumo de mergulho obtidos foram agrupados segundo a hierarquia das séries, tamanho e respectiva espessura, e contemplaram ainda uma representatividade mínima do número de medidas por afloramento, sugerido por McKee (1963), em cerca de 30 medidas para séries de pequeno porte (entendidas aqui como na escala de superfícies de $3^{\mathrm{a}}$ ordem ou menores). Nos histogramas circulares foram calculados quatro parâmetros estatísticos, número de medidas, percentagem máxima, média e desvio padrão.

\subsubsection{Confecção de rosáceas dos azimutes de mergulho de estratificações cruzadas}

Utilizou-se o programa Rockware, versão 1995, para confeccionar as rosáceas, com base nas estratificações cruzadas de ângulo maior que $10^{\circ}$. Cabe ressaltar que as estratificações com mergulho que esse valor têm a interpretação de seus azimutes complicada por sua possível associação com pés-de-dunas ou com formas de leito incipientes (lençóis de areia), ambas as feições afetadas ou formadas por ventos secundários. Considerou-se também que o baixo ângulo de mergulho aumenta a margem de erro na tomada do azimute de mergulho e contribui assim para um incremento na dispersão nessas medidas. Face a essas considerações e objetivando diminuir a 
incerteza na dedução do rumo dos ventos principais, as atitudes com ângulo de mergulho menor que $10^{\circ}$ foram consideradas à parte.

\subsubsection{Análise dos ângulos de mergulho com base em parâmetros estatísticos}

Para a análise dos ângulos de mergulho foi construída uma tabela constituída por funções estatísticas, através do programa Microsoft ${ }^{\oplus}$ Excel, com cálculos de parâmetros como média simples, moda, mediana, desvio padräo, máximo, mínimo, dentre outros. Nesta tabela foram estudados à parte os ângulos de mergulho menores que $10^{\circ}$.

Procedeu-se a interpretação qualitativa dos parâmetros, com o intuito de fornecer critérios para a distinção entre as fatias estratigráficas previamente estabelecidas.

\subsubsection{Análise dos dados obtidos em laboratório}

A partir dos resultados brutos de distribuição granulométrica obtidos através das técnicas de pipetagem e peneiramento, calcularam-se os valores de parâmetros estatísticos (diâmetro médio, desvio padräo, assimetria e curtose) pelo método analítico dos momentos de Pearson, através do programa Momento4.123, de Paulo C.F. Giannini.

Testes estatísticos simples, como médias e desvios padrões, foram aplicados aos resultados granulométricos, procurando estabelecer caracteristicas diagnósticas de cada agrupamento de amostras. Os critérios de agrupamento utilizados foram a posição estratigráfica, as fácies e a região geográfica. Quanto à posição estratigráfica, estabeleceram-se quatro grupos de amostras, de classificação informal: Pirambóiainferior, Pirambóia-superior, Botucatu-inferior e Botucatu-superior. Procedimento semelhante foi aplicado aos resultados de teores em massa de minerais pesados por amostra.

\section{REVISÃO BIBLIOGRÁFICA}

Na pesquisa bibliográfica, procurou-se evitar o que Lavina (1991) classificou como perda de sentido, isto é, o retrocesso que se empreende ao se descartar publicações, por considerá-las, por exemplo, ultrapassadas.

Procurou-se precaver também contra o que Della Fávera (1991) descreveu como emergência do primeiro paradigma ou barreira psicológica. Entende-se como paradigma 
ou barreira psicológica a reprodução pura e simples de teorias e modelos descritos por um determinado autor, o que significa ter certeza de algo e deixar em segundo plano o teste, ou falseamento, de hipóteses formuladas. Este procedimento desrespeita o método científico (Popper 1968, 1972, 1975), e implica sérios riscos de invalidar dados preciosos, simplesmente porque não se encaixam no modelo em voga.

Cabe destacar que a maioria das publicações sobre o Grupo São Bento está quase sempre restrita a resumos em congressos e simpósios, ou a relatórios internos (relacionados no Quadro 03 , no final deste capítulo), nem sempre disponíveis para consulta.

\subsection{Geomorfologia}

Na parte norte do Estado do Paraná, próximo à fronteira com São Paulo, Maack (1953) mapeou grande quantidade de morros testemunhos ou mesetas de arenito Botucatu recobertos por trapps (Termo de origem sueca que significa degrau).

Soares (1973) descreveu características de relevo arredondado e escalonado para os arenitos Pirambóia, e destacou a maior ocorrência da Formação Pirambóia no centro-leste paulista, cujos afloramentos apresentam-se sob forma de encostas escalonadas e extensos areais existentes sobre as colinas tabuliformes. Porém, na sua porção basal, caracterizou pequenas colinas com encostas côncavo-convexas, com desenvolvimento de solo agrícola. Atribuiu aos arenitos da Formação Botucatu, ocorrência restrita à parte inferior da escarpa da Serra Geral. Entretanto, segundo o mesmo autor, o arenito Botucatu pode ocorrer sob forma de morros testemunhos pouco afastados da frente da serra, ou em faixas amplas coberta por extensos areais eluvionares ou coluviais.

Ferreira (1979) definiu para a região da serra do Limoeiro, proximidades de Bofete, SP, critérios aerofotogeológicos para a identificação da Formação Pirambóia. As camadas com estratificações plano-paralelas, marcadas pela presença de siltitos e pela menor permeabilidade, propiciariam a ocorrência de nascentes e zonas de exsudação, reconhecíveis em foto aéreas.

Em mapeamento efetuado para o consórcio Paulipetro, a Promon (1980) descreveu, como feição típica de relevo das formações Botucatu e Pirambóia, escarpas subverticais de dimensões consideráveis. Encontraram-se grutas em rocha sã, 
praticamente não fraturada, como resultado de erosão da escarpa, relacionada a friabilidade da rocha.

Para Riccomini et al. (1984), a principal feição de relevo que permite, mesmo em foto aérea, a individualização da Formação Pirambóia na serra do Cadeado, próximo de Mauá da Serra, PR, está condicionada à ocorrência de extensos platôs em elevadas altitudes (mesetas), todavia silicificados, cujas rochas sobrejacentes teriam sido erodidas devido ao soerguimento, implementado no contexto do Arco de Ponta Grossa.

As serras seriam sempre sustentadas por arenitos silicificados ou pela ocorrência de derrames da Formação Serra Geral. Para explicar os processos responsáveis pela silicificação dos arenitos, inúmeros autores desde Florence (1907 apud Paraguassu, 1968) elaboraram a mais diversificada gama de hipóteses.

$\mathrm{Na}$ primeira publicação sobre os processos atuantes na migração de sílica, Florence (1907 apud Paraguassu 1968) constatou a presença de grãos de quartzo dispostos em fraturas de rochas igneas, cimentados por sílica, e associou esta cimentação à migração de sílica do basalto. Posteriormente, inúmeros autores tentaram aprimorar a compreensão dos processos de silicificação dos arenitos. Há uma tendência, por parte destes autores, em acreditar que a fonte de sílica é o próprio arenito (Freyberg 1927; Washburne 1930; Moraes Rego 1930; Leinz 1938; Almeida \& Barbosa 1953; Wernick 1966; Paraguassu 1968, 1972; Coimbra 1981 e Matos 1995). Nesse âmbito, a teoria mais viável parece ser a de Paraguassu (1968). Este autor demonstrou em laboratório a migração de sílica em arenito, submetido a fluxo contínuo de água destilada. Mais tarde, o mesmo autor relacionou, em afloramento, uma tendência de silicificação na frente da cuesta, em resposta à maior circulação de água. Esta silicificação poderia estar intimamente ligada à área de descarga do aqüifero, ao afloramento do lençol freático, à atuação de água meteórica e a variações de pH (Paraguassu 1972). Francis (1984 apud Rohn 1994) sugere que o pH elevado, em condiçōes hipersalinas, representaria um fator ideal para o desenvolvimento de processos de silicificação singenética por quartzina.

\subsection{Estratigrafia}

O termo Arenito Botucatu foi introduzido por Gonzaga de Campos (1889 apud Salamuni \& Bigarella 1967) para arenitos com estratificações cruzadas de grande porte, sotopostos ou intercalados a derrames basálticos da serra de Botucatu, no Estado de São Paulo. Englobava toda a sucessão psamítica pré-vulcânica. Conforme ressaltou 
Soares (1973), este primeiro uso do termo deu-se em contexto de descrição litológica, sem contemplar aspectos estratigráficos ou interpretações genéticas.

A introdução da designação Camadas Pirambóia ou Arenitos Pirambóia refere-se a camadas de argilitos, siltitos e arenitos argilosos aflorantes em Pirambóia, SP, abaixo do trapp (aqui usado no sentido de derrame) mais antigo, e deve-se à Comissão Geográfica e Geológica do Estado de São Paulo (Pacheco 1927 apud Paraguassu 1968). No mapa geológico de São Paulo apresentado por esta Comissão e constante no trabalho de Florence e Pacheco (1929 apud Washburne 1930), os Arenitos Botucatu e Pirambóia já se encontravam mencionados na legenda, apesar de ainda englobados dentro de uma mesma unidade de mapeamento. Em função da mapeabilidade então mal definida das duas unidades, alguns autores à época interpretaram os Arenitos Pirambóia como camadas intercaladas dentro da unidade Botucatu. Existiam desse modo dois sentidos para a designação Arenitos Pirambóia e Botucatu, a de unidades estratigráficas distintas, e a de fácies distintas, podendo ou não estar a primeira intercalada dentro da segunda. Para enfatizar que o emprego do termo Botucatu encaixava-se na primeira acepção, Washburne (1930) utilizou a designação Arenito Botucatu sensu strictu para a unidade superior de arenitos considerados eólicos, em distinção à unidade inferior Arenito Pirambóia, tida pelo autor como de deposição subaquosa. Formalizou-se, assim, pela primeira vez, uma subdivisăo de caráter estratigráfico entre as duas unidades, apoiada em critérios genéticos. Também favorável a uma distinção litoestratigráfica entre os arenitos Pirambóia e Botucatu foi o trabalho de Moraes Rego (1932), que defende a idéia, recentemente trazida à tona por Riccomini (1995), de existência de um derrame entre as duas unidades (trapp mais antigo) além de outros sobre a Formaçäo Botucatu, pelo menos no Estado de São Paulo.

As propostas de Washburne (1930) e Moraes Rego (1932) forneceram novos e diferentes argumentos à idéia de distinção entre os dois tipos de arenitos. Com isto, a legenda da nova carta geológica do Estado de São Paulo, publicada em 1947 (apud Soares 1973), manteve o uso dos termos Pirambóia e Botucatu como unidades distintas, ainda que, mais uma vez, não separadas em mapa.

Nesse contexto, Maack $(1947,1952)$ e Bigarella (1948) iniciaram as primeiras proposições sobre os arenitos da Série São Bento no Estado do Paraná. Maack (1947, 1952) descreveu a Série São Bento, composta de arenito inferior ou Botucatu, representante de sedimentação em paisagem desértica, com espessura entre 50 e $260 \mathrm{~m}$, sotopostos às lavas da serra Geral. Logo abaixo dos arenitos espessos, existiriam 
arenitos fluviais, argilosos vermelhos, com estratos de pedregulho, limitados em sua base por discordância de erosão e transgressão, com espessura de 5 a $10 \mathrm{~m}$. O autor tinha dúvida quanto à denominação Pirambóia, atribuindo-Ihe status mais de fácies subaquosa que propriamente de formação.

Bigarella (1948) incluiu nesta série os arenitos Botucatu e Caiuá, além dos espessos derrames basálticos.

Almeida \& Barbosa (1953) adotaram o critério genético de subdivisão PirambóiaBotucatu introduzido por Washburne (1930), que associava fácies subaquosas ao Pirambóia e de dunas e lençóis de areia ao Botucatu, mas questionaram a espessura atribuída pelo autor aos Arenitos Pirambóia, a qual, segundo eles, não passaria de poucos metros no Estado de São Paulo. O Arenito Pirambóia seria assim, na acepção de Almeida \& Barbosa (1953), o membro inferior da Série São Bento, com caráter fluvial, sobreposto por uma intercalação entre fácies eólicas (Arenito Botucatu), fácies lacustres de ocorrência local (Santana) e derrames basálticos. Almeida (1953) enfatizou o caráter subordinado das intercalaçöes lacustres (Arenito Santana) e aluviais de canal e inundação (Arenito Pirambóia), em contraste ao predomínio de deposição eólica. Concluiu pela existência de um contexto desértico seco para a deposição de todo o conjunto, e referiu-o sob a designação Deserto Botucatu.

Sanford \& Lange (1960) consideraram o Pirambóia e o Botucatu como formaçőes distintas. Todavia, a grande maioria das publicações da década de 60 ainda incluía a seção mesozóica pré-vulcânica inteira na Formação Botucatu, utilizando qualificações como fácies ou litótipo para as unidades Pirambóia e Santana. A respeito da interpretação faciológica, os autores dividiam-se entre os que atribuiam maior importância à deposição eólica (Maack 1947, 1952; Bigarella 1948; Salamuni \& Bigarella 1961, 1967; Mendes 1961) e os que enfatizavam a ação intermitente de transporte subaquoso (Paraguassu 1968; Fúlfaro \& Bósio 1968). Mendes (1971) chegou a considerar inviável o uso dos termos Pirambóia e Santana para diferenciar fácies subaquosas do Botucatu, uma vez que toda a seção correspondente aos dois terços inferiores da Formação Botucatu apresentaria, segundo ele, franco predomínio de sedimentos subaquosos. Bósio (1973) utilizou os termos fácies Pirambóia e fácies Botucatu para distinguir respectivamente depósitos fluviais do tipo braided de depósitos eólicos. Dentro da fácies Pirambóia, distinguiu os sedimentos de canal, com estratificações cruzadas, dos materiais siltosos de planícies de inundação, com estratificações plano-paralelas. 
O mesmo argumento empregado por Mendes (1971) para refutar o uso dos termos Pirambóia e Santana enquanto fácies poderia ser utilizado para defender o uso do termo Pirambóia enquanto unidade estratigráfica caracterizada por litologias de deposição subaquosa. Nesta linha de raciocínio, e com base no fato histórico de que a denominação Pirambóia sempre estivera, até então, associada a depósitos sedimentares de origem subaquosa, Soares (1973) propôs a designação destes depósitos como Formação Pirambóia. $\mathrm{O}$ autor dividiu também a formação aflorante em Săo Paulo em dois membros informais, distintos no campo por contrastes sutis de texturas e estruturas sedimentares e por diferenças de relevo, conforme destacado no item Geomorfologia. Segundo o autor, a seção-tipo ao longo de cortes da rodovia Marechal Cândido Rondon entre Conchas e a serra de Botucatu não contemplaria uma visäo de conjunto do Pirambóia.

A divisão proposta por Soares (1973) para o pacote sedimentar mesozóico prévulcânico da Bacia do Paraná foi adotada quase como norma, pelo menos no que se refere às formações Pirambóia e Botucatu. $O$ caráter dominantemente subaquoso da Formação Pirambóia, utilizado originalmente como principal critério de divisão, tem sido, no entanto, objeto recente de questionamento. Lavina (1991) em extensa pesquisa na borda da Bacia do Paraná determinou associações de fácies de processos eólicos representados por campos de dunas, sistema fluvial entrelaçado e lagos de deserto. Caetano-Chang (1997), estudando a Formação Pirambóia na borda leste da bacia, em São Paulo, mais especificamente na serra de São Pedro, reconheceu a presença e 0 predomínio de texturas e estruturas consideradas diagnósticas de deposição em frentes de dunas eólicas e interdunas, com destaque para a textura pin-stripe de Fryberger \& Schenk (1988). As fácies subaquosas, associadas segundo a autora a rios efêmeros (oueds), teriam registro subordinado na unidade.

No que concerne à Formação Botucatu, os trabalhos do IPT (1981) e de Riccomini et al. (1984) descreveram-na como constituída por arenitos avermelhados a esbranquiçados, de granulação fina, bem selecionados e com grãos arredondados. As estratificações cruzadas seriam de grande porte, do tipo tabular, bem laminada com bimodalidade representada por freqüente recorrência entre lâminas com grãos finos e médios. Os grãos seriam quase que exclusivamente de quartzo, com presença secundária de opacos, muscovita, minerais pesados e fragmentos de quartzito. Concluíram assim tratar-se de quartzo arenito. 
Haveria, segundo Caetano-Chang (1997), um certo consenso sobre a gênese da Formação Botucatu. Todavia, ainda são freqüentes questões sobre sua identificação, superfícies de truncamento, tipos e dimensões de dunas, área fonte e paleoclima. Almeida (1950) e Carneiro \& Almeida (1998) levantam a questão da presença obrigatória de evaporitos em ambientes áridos quentes, até o momento não encontrados na Formação Botucatu. A presença de pegadas de répteis atribuídas à Formação Botucatu, descrito por Leonardi $(1986 ; 1994)$ nas regiōes de Araraquara, Botucatu e norte velho paranaense (Jacarezinho) reforça o questionamento da interpretação clássica de paleoclima muito seco na Formação Botucatu. Segundo o autor, répteis bem desenvolvidos como estes dificilmente sobreviveriam em clima tão árido, mesmo que se presumisse a existência de oásis bem desenvolvidos.

Fernandes et al. (1990) descreveram icnogêneros em lages de arenito silicificado atribuídas ao Botucatu. Identificaram as espécies Taenidium satanassi e Taenidium serpentinium, descritas como pistas de vermes por Pacheco (1913 apud Fernandes 1990). Este tipo de icnofóssil, que indica existência de areias úmidas, é comum na Formação Pirambóia, onde seu registro estaria relacionado à influência costeira e fluvial (Giannini 2001). Com base na descrição de Fernandes et al. (1990) para os arenitos com icnofósseis, seria possível supor que não se trate, na realidade, de arenito Botucatu e sim de arenito Pirambóia.

Outras características dos arenitos Pirambóia que cabe ressaltar são os achados de vegetais superiores silicificados, dispostos em fácies subaquosas da Formação Botucatu em Minas Gerais, descritas por Suguio \& Coimbra (1972), que poderiam ser atribuídas ao sistema Pirambóia. Há ainda menção de impressões de Muensteria em amostras de Caetano-Chang (1997) procedentes dos arredores de Piracicaba, SP, e de poços perfurados em Anhembi, SP. Já em afloramento, Caetano-Chang (1997) interpretou, com base em estruturas colapsadas e contatos erosivos, a ocorrência de pegadas de répteis.

\subsubsection{O contato basal da Formação Pirambóia}

A primeira publicação que abordou, dentre outros assuntos, o contato basal da Formação Pirambóia foi executado por White (1908 apud Schneider 1974) em Santa Catarina, seguido, no Paraná, de Maack $(1947,1952)$ e Bigarella $(1948,1967)$. Maack 
$(1947,1953)$ caracterizou o contato inferior desta unidade como erosivo, repousando em discordância angular sobre camadas da série Passa Dois ou diretamente sobre rochas cristalinas. Após cinco anos de pesquisas, o mesmo autor determinou a existência de grande discordância com hiato significativo, nas regiões da serra da Esperança, PR, e serra da Bocaina, SC, exatamente 19m abaixo do arenito Botucatu e $1 \mathrm{~m}$ acima de horizontes vermelhos do Grupo Rio do Rasto. Em termos temporais, a discordância estaria relacionada a passagem entre o Permiano superior e o Triássico médio, servindo de critério para que se determinassem as camadas Rio do Rasto como triássicas.

O trabalho de Fúlfaro (1972) foi pioneiro em atribuir ao contato basal da Formação Pirambóia um caráter transicional, mesmo em seu domínio paulista, onde é claramente marcado pela presença de brecha intraclástica, denominada de rególito fóssil. Descreveu a presença desta brecha no topo e em meio às camadas superiores do Grupo Passa Dois. Portanto, não haveria um hiato erosivo significativo na passagem entre a sedimentação dos siltitos do Passa Dois com os arenitos do Grupo São Bento. Esta afirmação foi, segundo o mesmo autor, obtida não apenas pela descrição da morfologia do contato de topo da Formação Corumbataí, como da presença de fósseis permianos, Lycopodiopsis derbyi, na base da Formação Pirambóia.

Com o mapeamento realizado para a Petrobrás, Soares (1973) descreveu a parte centro-leste da Bacia do Paraná em São Paulo e exposições da serra da Esperança, entre Guarapuava e Prudentópolis, PR, concluindo por contato discordante entre a Formação Corumbataí e o Grupo Estrada Nova, representado pelo litótipo Terezina. Interpretou-a com base da ocorrência de regolito fóssil no contato entre as formações Corumbataí e Pirambóia dentro dos limites do Estado de São Paulo. Haveria, dessa forma, um hiato significativo na base da Formação Pirambóia. Salientou, porém, que do ponto de vista textural, em localidades como Anhembi, Conchas e proximidades da fazenda Moquém, o contato seria uma passagem gradual entre siltitos arenosos do topo do Estrada Nova e arenitos siltosos da base do Pirambóia.

Vieira \& Maingué (1972) descrevem uma passagem em parte abrupta e em parte gradativa, no contato basal da Formação Pirambóia, considerando a continuidade lateral deste contato.

Schneider et al. (1974) descreveram passagem discordante na base da Formação Pirambóia e em seu topo.

Riccomini et al. (1984) demonstraram em mapeamento na região da serra do Cadeado, proximidades de Mauá da Serra, PR, que a transição Rio do Rasto - Pirambóia 
é caracterizada por intercalações arenosas que tornam-se cada vez mais freqüentes para o topo, acompanhado de um sutil incremento granulométrico (...) o que é facilmente observado no Morro do Mulato. Na mesma serra, a passagem seria representada por arenitos finos, avermelhados, mal selecionados, com laminação cruzada acanalada de grande porte e intercalações de siltitos da Formação Rio do Rasto, para arenitos róseos mal selecionados com granulação média a fina e estratificação cruzada acanalada de grande porte, pertencentes ao Pirambóia.

Lavina (1991) estudou praticamente toda a faixa aflorante no Brasil e, ainda, Paraguai, Uruguai e Argentina do intervalo Kazaniano-Citiano da Bacia do Paraná (desde a Formação Irati inferior até a Formação Serra Geral), o que permite uma interpretação mais rigorosa quanto a paleogeografia. O contato basal da Formação Pirambóia foi caracterizado por este autor como concordante e gradual em relação ao Grupo Passa Dois, sendo interpretado como associações faciológicas que transicionam lateral e verticalmente para a Formação Pirambóia, seguindo as variações do onlap costeiro. Sua descrição relaciona contatos discordantes de cunho local. Desse modo, admitiu no Estado de São Paulo, por exemplo, o desenvolvimento de diastema, excluindo a possibilidade de discordância generalizada para toda a bacia. Posicionou fácies eólicas no topo da Formação Rio do Rasto sugerindo um contexto de aridização gradual, já a partir do final da sedimentação desta unidade.

Rohn (1994), em região que denominou de paleoborda da bacia, situada, segundo a autora, nos arredores de Santo Antônio da Platina, PR, determinou a ausência de parte do registro sedimentar do topo da Formação Rio do Rasto no Paraná. Entretanto admite que na rodovia PR-090, haveria algumas exposições que atestam o caráter transicional do contato Rio do Rasto/Pirambóia. Em Cândido de Abreu, PR, quedas acentuadas do nivel de base teriam erodido parte da coluna sedimentar, interpretando uma discordância intraformacional, neste mesmo intervalo.

Matos (1995), baseado em informações de poços e afloramentos na borda leste da Bacia do Paraná, descreve contato abrupto, não erosivo, entre camada de brechas, a qual denominou informalmente de Camada Porangaba, e os arenitos Pirambóia. Esta camada representaria intercalações entre níveis silicificados brechados e siltitos que se repetem na coluna sedimentar desde a Formação Corumbataí, com até $27 \mathrm{~km}$ de extensão e afinamento para oeste.

Em arenitos do Estado de São Paulo, Caetano-Chang (1997) descreve contato erosivo com discordância entre brechas e lamitos avermelhados, texturalmente imaturos, 
muito finos a grossos, mal selecionados, subangulosos, de aspecto maciço, com níveis descontínuos de siltitos calciferos e calcários.

Milani (1997), baseado em dados de perfilagem geofísica de poços perfurados pela Petrobrás e descrição de afloramentos, distribuídos por quase toda a Bacia do Paraná, considera o contato basal da Formação Pirambóia como interdigitado. Caracteriza lenticularidade da Formação Pirambóia tanto a sul do Paraná quanto em todo - Estado de Santa Catarina. Essa tendência de interdigitação é aceita por Montanheiro (1999) na coluna litoestratigráfica elaborada para o Estado de São Paulo (Figura 06).

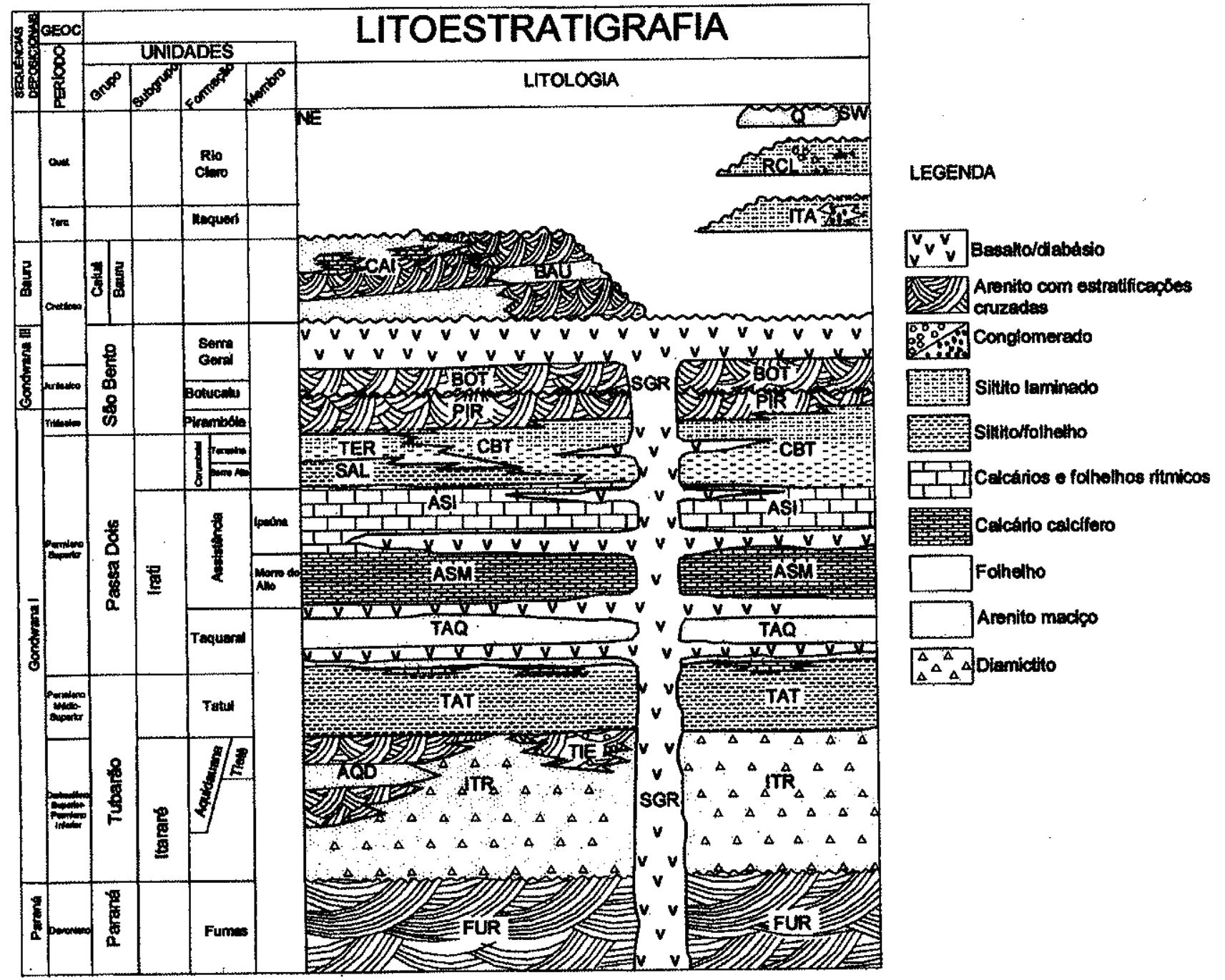

Figura 06 - Diagrama cronolitoestratigráfico da Bacia do Paraná proposto por Montanheiro (1999). 


\subsubsection{A Passagem Pirambóia-Botucatu}

O melhor conhecimento da passagem Pirambóia-Botucatu pressupõe estabelecer critérios objetivos para a definição do contato e, por extensão, para a distinção entre as unidades.

Nos estados de São Paulo e Paraná, o contato entre as duas formações nas frentes de cuestas basálticas encontra-se em sua maior parte encoberto por depósitos de tálus (Soares 1973; Ferreira 1979; Promon 1980). Assim, as informações disponíveis na literatura a respeito desta passagem estão fundamentadas em análises de poucos afloramentos, amostras de calha e dados indiretos de perfilagem de poços. Essa base de dados e o enfoque litoestratigráfico não foram suficientes, até o momento, para a compreensão plena da passagem Pirambóia-Botucatu, no contexto evolutivo da Bacia do Paraná.

A descrição de Moraes Rego (1932) e CPRM (1980) sobre a ocorrência de um derrame separando as formações Pirambóia e Botucatu constitui um fator pouco explorado por pesquisas na Bacia do Paraná. Ressalta-se, entretanto, o fato de não haver critérios seguros ou consagrados para certificar-se de que o corpo magmático citado por Pacheco (1927 apud Paraguassu 1968), Moraes Rego (1932), Almeida (1953) e Riccomini (1995) é mesmo um derrame e não um sill entre os sedimentos de ambas as formaçōes. Ampla discussão a respeito da diferenciação entre magmatismo intrusivo ou extrusivo na Bacia do Paraná é realizada por Soares (1973), que concluiu pela inexistência de feições diagnósticas seguras. Independente desta discussão, a falta de critérios para a diferenciação entre os arenitos mesozóicos poderia ocasionar uma interpretação errônea quanto à posição dos magmatitos, se inseridos entre as duas formações ou dentro da Formação Botucatu.

Alguns autores (Vieira 1973; Bósio 1973; Soares 1973, 1975; Schneider et al. 1974; CPRM 1980; Riccomini et al. 1984; Riccomini 1995; Lavina 1991; Nishimura \& Zuquette 1994; Caetano-Chang 1997) associam à passagem Pirambóia-Botucatu a ocorrência de sedimentos rudáceos, o que representaria um indicador confiável da interface entre as formaçōes, especialmente se corresponder a um único nível. Existem, entretanto, discussões a respeito de sua posição estratigráfica, se no topo da Formação Pirambóia ou na base da Formação Botucatu, além de dúvidas sobre o grau de correlação entre os sedimentos conglomeráticos referidos por diferentes autores. A persistência lateral de niveis conglomeráticos entre as duas formações não se encontra 
bem definida na literatura, mesmo em seu domínio paulista, onde há vasto número de publicações sobre o tema. Um bom exemplo disto está na região sudoeste do Estado de São Paulo, na fronteira com o Paraná, nas proximidades das cidades de Piraju e Fartura. Lá não se conhece outra publicação que associe afloramentos de fácies rudácea com caráter de delimitante estratigráfico, como descritas por CPRM (1980). No modelo aventado nessa publicação, tal fácies não se repete dentro da Formação Pirambóia, dispondo-se somente nas adjacências do contato superior. A continuidade lateral, segundo o mesmo modelo, é representada por um derrame mais antigo, separando as formações, na mesma posição estratigráfica dos conglomerados.

Maack (1947, 1952) verificou que havia recorrência de bancos e lentes de cascalho dentro dos arenitos Pirambóia, inseridos por ele na base dos arenitos do Grupo Botucatu.

Vieira \& Maingué (1972), estudando regiões de São Paulo e Paraná, relatam um arenito conglomerático de cerca de cinco metros de espessura na base da Formação Botucatu, em contato discordante sobre a Formação Pirambóia. Bósio (1973) refere-se a arenitos conglomeráticos formados por processos de deposição fluvial e posiciona-os no topo da Formação Pirambóia, sem indicar discordância. Soares (1973) interpreta arenitos conglomeráticos presentes nessa interface em afloramentos dos estados de São Paulo e Paraná, como fácies torrencial do pavimento desértico sobre o qual viriam a se depositar as grandes dunas eólicas. Posiciona-os portanto na base da Formação Botucatu, sem discordância.

Para Soares \& Landim (1976) a presença de conglomerados na parte superior da Formação Pirambóia e na basal da Formação Botucatu atestaria um rápido desenvolvimento da borda oriental da bacia e reativação do Arco de Ponta Grossa, no Triássico-Jurássico, correspondendo ao soerguimento crustal pré-rift. Interpretam que há conglomerados dispostos tanto no topo da Formação Pirambóia quanto na base da Formaçăo Botucatu.

IPT (1981) e Riccomini et al. (1984) com base na ocorrência generalizada, que se repete na coluna sedimentar, de níveis conglomeráticos dentro da Formação Pirambóia, na serra do Cadeado, município de Mauá da Serra, PR, questionaram o posicionamento estratigráfico dos conglomerados referidos por Vieira \& Maingué (1972) na base do Botucatu. Na mesma área, os autores observaram um aumento da freqüência de níveis conglomeráticos para o topo da Formação Pirambóia. No entanto, os autores assumiram 
a falta de critérios para diferenciar as duas formações, o que torna difícil um posicionamento litoestratigráfico mais confiável destes níveis conglomeráticos.

Assine (1993) associa fácies eólicas a fácies rudáceas para a Formação Pirambóia em seu domínio paulista. A primeira fácies ocorre na base da formação, e exibe, como estruturas sedimentares, estratificações cruzadas tabular tangencial e/ou acanalada, com séries de um a cinco metros de espessura, por ele atribuídas a sedimentação tipicamente eólica. A segunda fácies, posicionada na metade superior da unidade, corresponde a arenitos seixosos e/ou conglomeráticos, com estratificações de no máximo dois metros de espessura, separados por linhas de seixos. $O$ final da sedimentação da Formação Pirambóia, segundo a descrição do autor, seria registrada por séries decimétricas de arenitos finos a grossos, com predomínio de termos finos, associados a depósitos de interdunas úmidas - overbank.

Riccomini (1995) considera os conglomerados da interface como superfície de deflação relacionada à acentuação, durante o Jurássico, da ascensão pré-ruptura. Posiciona-o no topo da Formação Pirambóia.

Caetano-Chang (1997) denomina de Arenito Itirapina uma unidade arenoconglomerática, por ela inserida no topo da Formação Pirambóia. Para esta autora, estes arenitos seriam formados por depósitos de canais entrelaçados e de leques aluviais. Estaria correlacionada vertical e lateralmente a arenitos eólicos da Formação Pirambóia, limitados em seu topo por uma superfície discordante erosiva, subjacente à base da Formação Botucatu. Ainda de acordo com esta autora, a presença de superfície de discordância erosiva entre as formações Pirambóia e Botucatu permite interpretar um período de deflação eólica posterior ao fechamento da sedimentação Pirambóia atuante sobre vastas áreas continentais.

\subsubsection{Soleiras e derrames associados à Formação Serra Geral}

Bigarella (1948) classificou os arenitos eólicos infrabasálticos do Grupo Botucatu em dois tipos fundamentais: dunas movediças e escudos basais de areia (lençóis). Propôs, ainda, um terceiro tipo, que considerou como fácies subaquática. Cabe ressaltar que o reconhecimento desta última fácies apoiava-se nos valores mais baixos dos coeficientes de seleção granulométrica obtidos em análises laboratoriais.

Inúmeros autores desde Almeida (1950; 1953) até Milani (1997) admitiram a existência de bombas piroclásticas dentro da Formação Botucatu, concluindo pela 
ocorrência de magmatismo explosivo, contemporâneo à sedimentação da porção superior da Formação Botucatu, na serra de Botucatu, SP, nas proximidades de cidade homônima. A sedimentação eólica, segundo esses mesmos autores, seria responsável pelo paleorelevo ondulado ainda hoje detectado no contato entre o Botucatu e o derrame de lavas basálticas.

Soares (1973) acredita que as lavas recobriram dunas ainda inconsolidadas, sugerindo contemporaneidade entre a sedimentação Botucatu e o magmatismo da Formação Serra Geral. 


\begin{tabular}{|c|c|c|c|}
\hline Autor/ano & Idade & Sistema Deposicional & Local \\
\hline Washburne (1930) & - & fluvial & $\mathrm{SP}$ \\
\hline Maack (1952) & rético & fluvial & PR \\
\hline Bigarelia (1948) & rético & fluvial & PR \\
\hline Almeida \& Barbosa (1953) & -- & fluvial & Piracicaba e Rio Claro, SP \\
\hline Almeida (1954) & $\begin{array}{l}\text { Triássico (fáunula de } \\
\text { conchostráceos) }\end{array}$ & lacustre (topo) fluvial (base) & SP-PR-SC \\
\hline Franzinelil (1973) & on & predomínio fluvial & $\begin{array}{l}\text { Entre SW dos rios Paranapanema } \\
\text { e Tietê. NE do rio Piracicaba }\end{array}$ \\
\hline Soares (1973) & - & fluvial & SP \\
\hline $\begin{array}{c}\text { Thomaz (1976 apud Leonardi } \\
\text { 1980) }\end{array}$ & Jurássico (Aaleniano) & fluvial & Araraquara SP \\
\hline Riccomini et al. (1984) & Permo-Triássico & fluvial & serra do Cadeado PR \\
\hline Cottas et al. (1986) & - & fluvial & $\begin{array}{l}\text { NE de SP, Guarapuava e Ponta } \\
\text { Grossa do PR }\end{array}$ \\
\hline Caetano-Chang et al. (1991) & - & eólico, fluvial subordinado & São Pedro, SP \\
\hline Lavina \& Faccini (1992) & $\begin{array}{l}\text { Permo-Triássico (Tatariano- } \\
\text { Eocitiano) Tetrápodes Rio do } \\
\text { Rasto e Sanga do Cabral }\end{array}$ & $\begin{array}{c}\text { eólico com flúvio lacustre } \\
\text { subordinado }\end{array}$ & $\begin{array}{c}\text { Depressão situada a W e NW do } \\
\text { escudo do RG }\end{array}$ \\
\hline Caetano-Chang \& Wu (1994) & Triássico & eólico, fluvial subordinado & São Pedro, SP \\
\hline Lavina (1991) & Tatariano-Citiano & flúvio-eólico & $\begin{array}{l}\text { BRASIL-URUGUAI-PARAGUAI- } \\
\text { ARGENTINA }\end{array}$ \\
\hline Caetano-Chang (1997) & Triássico & flúvio-eólico & Centro-Leste de SP \\
\hline Milani (1997) & Tatariano-Citiano & flúvio-eólico & $\begin{array}{l}\text { BRASIL-URUGUAI-PARAGUAI- } \\
\text { ARGENTINA }\end{array}$ \\
\hline Giannini et al. (1999) & Permo-Triássico & $\begin{array}{l}\text { transicional (costeiro, fluvial, } \\
\text { eólico) }\end{array}$ & SP-PR \\
\hline
\end{tabular}

Quadro 02 - Evolução dos conhecimentos da Formação Pirambóia (Modificado de Sgarbi 1997). 


\subsection{Sedimentologia das Formações Pirambóia e Botucatu}

\subsubsection{Paleocorrentes}

A literatura clássica sobre rumos de paleoventos na Bacia do Paraná contabiliza grande número de medidas, obtidas em ampla região, sem considerar sua distribuição em relação ao arcabouço litoestratigráfico da bacia e às associaçōes de fácies.

Publicações mais recentes sobre o intervalo permo-triássico levam em conta estes aspectos, porém restringem-se em termos de área geográfica ou de fatia estratigráfica dentro das unidades.

Almeida (1953) apresentou o resultado de 260 medidas de frentes de cruzadas de dunas eólicas, com ângulo de mergulho superior a $10^{\circ}$, atribuídas à Formação Botucatu (lato sensu), realizadas a leste do Estado de São Paulo. Percebeu uma tendência de dispersão para SSW, com medidas também nos rumos NW e NE. Admitiu a migração de dunas essencialmente barcanas, com direção predominante relacionada à atuação de ventos vindos de Norte.

Bigarella \& Salamuni $(1961,1967)$ realizaram cerca de 3.000 medidas de paleocorrentes das formações Pirambóia, Botucatu e Serra Geral (arenitos intratrapp) distribuídas nos estados do Sul, Sudeste, Centro-Oeste do Brasil e no Uruguai. Puderam observar rumos de paleoventos nas direçöes NE e SW, com convergência das medidas para o centro do Estado do Paraná.

Milani (1997), com base nos resultados de Bigarella \& Salamuni (1961), para os arenitos mesozóicos, atribui área fonte potencial a NNE, e como argumento, aponta suposta correlação entre as bacias cratônicas brasileiras com base nos dados de paleocorrentes. No flanco norte da Bacia do Paraná, Soares (1973) sugere paleoventos com rumo W e SW para a Formação Pirambóia.

Brighetti (1994 apud Caetano-Chang 1997) mediu rumos SSE na Formação Pirambóia aflorante na região de Rio Claro. Assine (1993) encontrou na região de São Pedro, para a mesma formação, rumos de paleoventos SE e SW e paleofluxo das fácies fluviais WNW.

Caetano-Chang (1997), em medição sistemática nos arenitos Pirambóia da região centro-leste do Estado de São Paulo (306 medidas), indica ventos rumo SE na porção 
inferior. Este rumo continuaria na porção mediana, porém com uma contribuição maior de NE e rumo SW no topo. Marca assim duas direçöes preferenciais de paleofluxo: NW basal e NE na porção superior. Indicou ainda uma persistência do rumo WNW nos arenitos conglomeráticos que denominou de arenito Itirapina.

Giannini et al. (1999b) observaram, na metade inferior da Formação Pirambóia, predomínio dos rumos de paleoventos SE e SW, em São Paulo, e NE e SW, no Paraná. Neste último, o rumo SW foi encontrado apenas em estratificações cruzadas de baixo ângulo $\left(<10^{\circ}\right)$, relacionadas a depósitos de pé-de-duna e lençóis de areia. Superfícies de truncamento de segunda ordem (sensu Kocurek 1996) apresentam baixo ângulo de mergulho para SW, o que permite sugerir a migração de draas nesse rumo. A porção superior foi caracterizada pelo domínio do rumo SW no Paraná, exceto na região centrosul do estado (Guarapuava), onde se torna marcante o rumo NE.

Em São Paulo, os rumos medidos por Giannini et al. (1999b) foram N, NW e SW, este último na região de Botucatu e São Pedro. Associaram a dispersão nos rumos de paleoventos a feiçōes do paleorelevo e/ou geometria da bacia. $O$ caráter transicional do contato inferior com os depósitos de maré do Grupo Passa Dois indicariam a proximidade com a paleocosta. Esta interpretação permitiu aos autores admitir a influência de ventos costeiros na distribuição dos azimutes, pelo menos nos estágios iniciais da sedimentação Pirambóia no Paraná.

\subsubsection{Mineralogia}

Por intermédio de análise da assembléia de minerais pesados do interior de São Paulo e estudo de seçōes delgadas, Wu \& Soares (1974), Wu (1981) e Wu \& CaetanoChang (1992) propuseram fonte de rochas metamórficas para os arenitos das formações Pirambóia e Botucatu. Descreveram franco predomínio de ZTR (zircão, turmalina e rutilo) bem arredondados, assim como a alta percentagem de estaurolita na Formação Pirambóia.

Suguio \& Coimbra (1974) atribuíram o alto arredondamento dos grãos das formaçōes Pirambóia e Botucatu a sucessivos retrabalhamentos dos sedimentos. Com base em dados de assembléia de minerais pesados e suas microfeiçōes texturais, indicaram a possibilidade de que fenômenos de soerguimento das porções interiores da bacia poderiam ser contemporâneos à deposição dos arenitos. 
Estudos petrográficos da Formação Pirambóia (Caetano-Chang 1997) indicaram a pequena percentagem de feldspato, possivelmente relacionada à área fonte essencialmente quartzosa. Entretanto, a presença de porosidade secundária registrada pela autora constitui um fator complicador nesta interpretação. A pequena percentagem de feldspato apontada pode estar relacionada a processos diagenéticos tardios (meso e telodiagênese). Cabe ressaltar que esta mesma diagênese poderia atuar na assembléia de minerais pesados, no sentido de dissolver parte da fração de minerais instáveis e metaestáveis.

\subsection{Idade}

\subsubsection{Correlação litoestratigráfica e datação relativa}

Os dados de idade mais precisos de que se dispõe dizem respeito à Formação Botucatu, baseados na premissa de contemporaneidade do contato superior com os derrames da Formação Serra Geral. Em relação à Formação Pirambóia, informações paleontológicas sobre seus afloramentos no Estado de São Paulo e do Paraná permitem interpretar idades desde permianas até triássico-jurássicas (Souza et al. 1972, Rohn 1994). Outro critério empregado para a datação da Formação Pirambóia é sua suposta correlação cronoestratigráfica com a Formação Rosário do Sul, mapeada apenas no Estado do Rio Grande do Sul. Dessa maneira, Soares (1973) atribuiu para o conjunto Pirambóia-Botucatu idade compreendida entre o Triássico inferior e o início da deposição eólica do Botucatu, no Jurássico superior. Admitiu para isso, a inexistência de hiato de tempo significativo na passagem Pirambóia-Botucatu e perfeita correlação da Formação Pirambóia com a Formação Rosário do Sul (Soares et al. 1987). Mais recentemente, diferentes autores têm sugerido um contato discordante entre as Formações Pirambóia e Botucatu (Schneider 1974; Riccomini et al. 1984; Caetano-Chang 1997), o que empurraria para posições estratigraficamente inferiores o topo da Formação Pirambóia. Assim, o limite superior desta unidade foi colocado sucessivamente no Triássico superior, por Zalán (1991), e no final do Carniano ou Triássico médio, por Milani (1994) e CaetanoChang (1997). Apesar das divergências quanto à correlação com a Formação Sanga do Cabral ou Rosário do Sul, Riccomini et al. (1984), Zalán (1991), Lavina (1991), Rohn (1994), Milani (1997) e Caetano-Chang (1997), têm admitido para a Formação Pirambóia uma idade Tatariana-Citiana (Permiano inferior e Triássico superior). 
Riccomini (1995) estima em 5M.a. o intervalo de tempo envolvido para a sedimentação da Formação Botucatu, posicionando-a quase que inteiramente no Cretáceo inferior. Entretanto, ressalta a caráter especulativo quanto à interpretação desse intervalo, o qual parte da premissa, ainda pouco aceita, da presença de um derrame ainda não datado entre as duas formações em questão.

\subsubsection{Geocronologia}

Cordani \& Vandoros (1967) dataram derrames no intervalo entre 147 e $119 \mathrm{Ma}$ (Jurássico superior-Cretáceo inferior) e admitiram a hipótese de íntimo relacionamento e perfeita contemporaneidade entre intercalaçōes de arenitos eólicos e basaltos da Formação Serra Geral. Determinações geocronológicas apresentadas em trabalhos mais recentes (Turner et al. 1994 e Renne et al. 1997) indicam que os derrames teriam ocorrido dentro de um intervalo mais restrito (137 a 127 M.a.). Com base nisso, e admitida a hipótese de contemporaneidade entre os derrames e a sedimentação Botucatu, a idade desta estaria dentro do mesmo intervalo de tempo (Riccomini 1995). A confirmação irrestrita desta hipótese esbarra na dificuldade de distinguir se os magmatitos posicionados na base e em meio aos arenitos são sills ou derrames, e de avaliar o possivel caráter intratrapiano da Formação Botucatu em relação aos derrames da Formação Serra Geral. A tentativa de Soares (1973) de fornecer critérios de distinção entre magmatitos intrusivos e extrusivos apenas faz por confirmar a complexidade e 0 grau de incerteza em torno desta questão. Assim, aceita a interpretação desse mesmo autor de que as relaçöes de contato com a base da Formação Serra Geral indicam ocorrência de derrames de lava sobre dunas eólicas ainda inconsolidadas, a afirmação mais segura que se pode fazer é a de que a Formação Botucatu não seria mais nova que cerca de $127 \mathrm{Ma}$.

As idades obtidas por métodos radiométricos apresentam problemas em relação aos critérios adotados para a coleta de amostras. Não está devidamente esclarecida nas publicações com resultados de datação a posição estratigráfica das amostras datadas. Isso implica dúvida sobre qual o derrame amostrado, e por extensão, identificar o evento datado (C. Riccomini, IG-USP, com. verbal). Nesse sentido, cabe ressaltar que existem mais de vinte derrames relacionados à Formação Serra Geral (Ernesto \& Pacca 1988). 


\section{RESULTADOS OBTIDOS}

\subsection{Introdução}

A apresentação e as interpretações de resultados a seguir têm como finalidade explorar os possíveis significados faciológico e paleogeográfico de diferenças ou semelhanças texturais, petrográficas e vetoriais entre distintos agrupamentos de amostras, previamente estabelecidos com base em parâmetros de campo. $O$ fornecimento de critérios de separação entre as formações Pirambóia e Botucatu foi outro objetivo básico da interpretação. Dentre os aspectos considerados a priori como determinantes potenciais de contrastes texturais e mineralógicos, incluíram-se: mudanças de área-fonte, dissolução intraestratal diferencial (freqüentemente relacionada à idade dos sedimentos), alterações no regime de paleoventos e paleocorrentes e autofagia da bacia.

\subsection{Análise de fácies}

\section{Fácies individuais}

São descritas oito fácies a seguir. As cinco primeiras podem ser relacionadas a sistema deposicional eólico com influência de processos subaquosos e, as três últimas, ao mesmo tipo de sistema deposicional, porém com pouca influência aparente de água.

Fácies Acb (Arenito com estratificação cruzada de baixo ângulo)

Arenito com estratificação plano-paralela ou estratificação cruzada acanalada de ângulo baixo (Figura 07 ), menor que $10^{\circ}$, em séries de espessura centimétrica a métrica (até $3 \mathrm{~m}$ ), eventualmente com porções maciças, possivelmente fluidificadas, no topo (pontos JC.03, JC.04, JC.10, JC.11, GR.10, SA.02, UV.01, GR.08, GR.09 e RP.07). Destaca-se a presença de superfícies de $3^{a}$ ordem, que se sucedem em intervalos decimétricos, e de microondulações (centimétricas) cavalgantes subcríticas transladantes com ângulo de mergulho de cavalgamento entre $10^{\circ}$ e $20^{\circ}$. Outra feição importante é a presença de siltito esverdeado com laminação heterolítica (predominantemente wavy) e 
estruturas de sobrecarga decimétricas a subcentimétricas (Figuras 08 e 09). Em escala centimétrica, observaram-se tubos do icnogênero Taenidium em areia média no ponto SA.02, localizado na região do Norte Velho do Paraná.

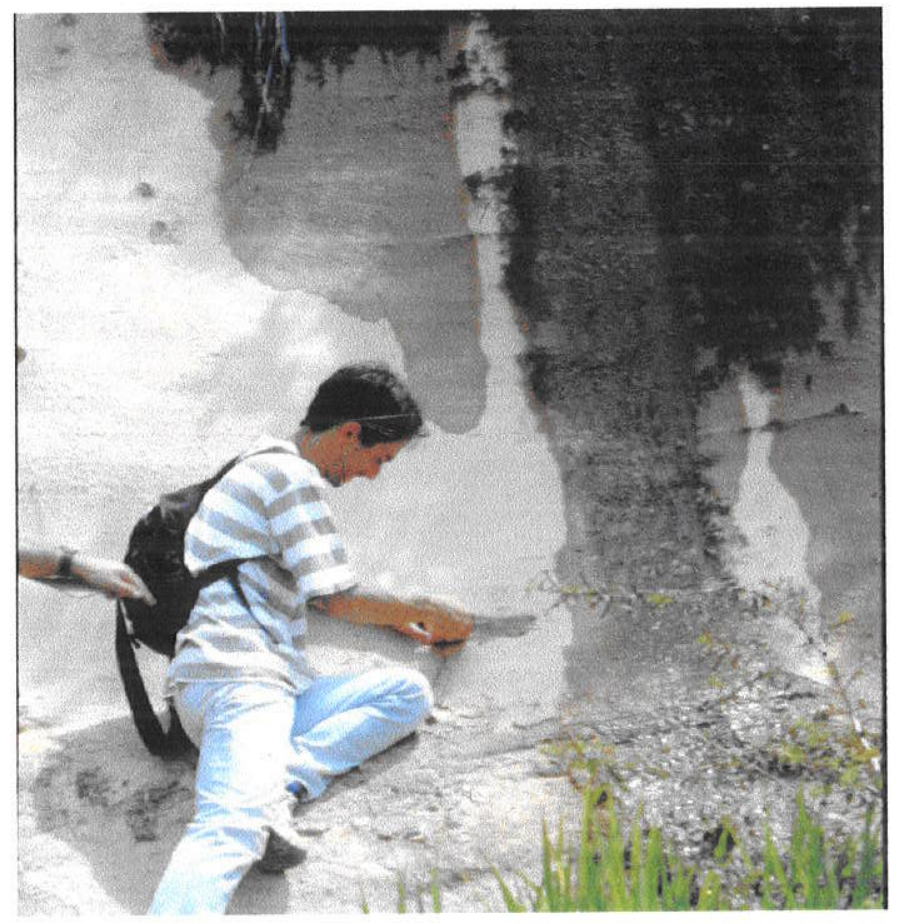

Figura 07 - Arenito muito fino com estratificação cruzada plano-paralela, passando acima a cruzada de ângulo inferior a $10^{\circ}$. Foto do ponto JC.11, da metade inferior da Formação Pirambóia, região norte do Paraná.

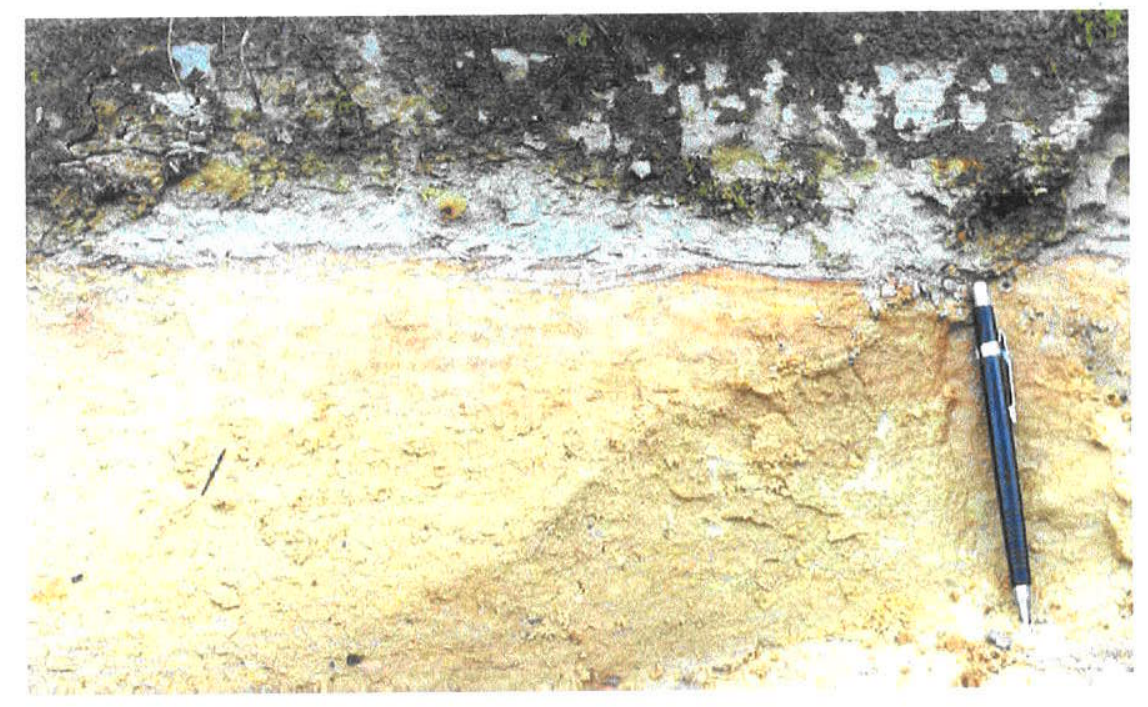

Figura 08 - Arenito fino sob lamito arenoso esverdeado. Notar laminação cruzada acanalada, próximo ao contato. Foto do ponto GR.10, Formação Pirambóia superior na serra da Esperança, região centro-sul do Paraná. 


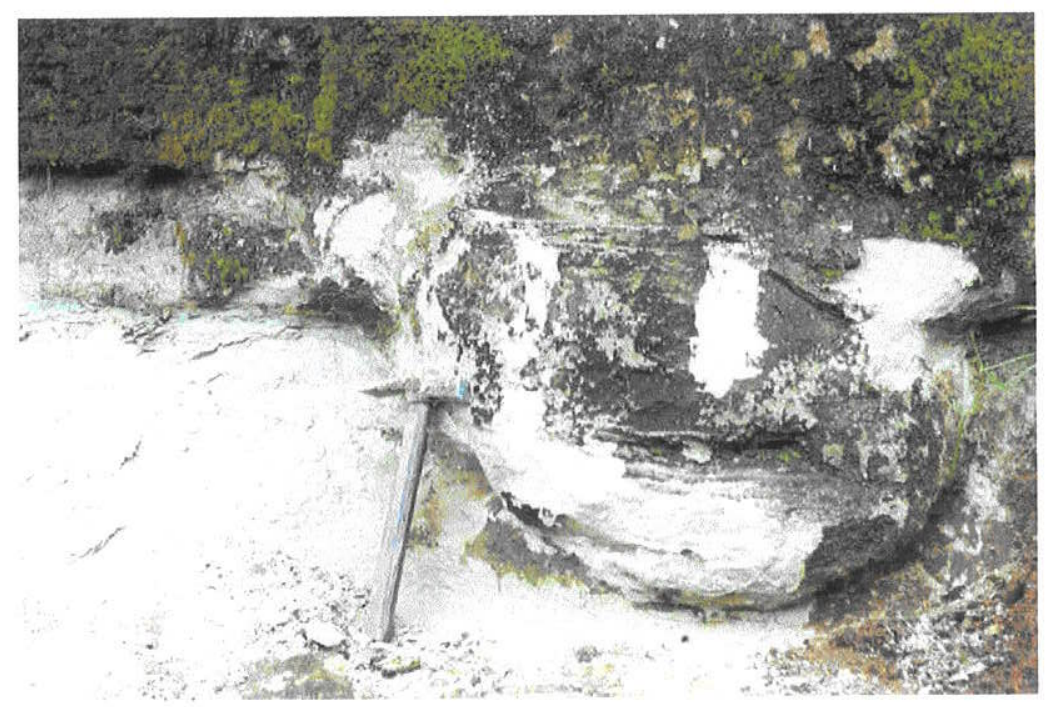

Figura 09 - Arenito fino sobre lamito arenoso esverdeado. Notar estrutura de sobrecarga em almofada no contato entre as litologias. Foto do ponto GR.10, Formação Pirambóia superior na serra da Esperança, região centro-sul do Paraná.

Com base nas características da fácies $\mathrm{Acb}$, pode-se interpretar pelo menos dois processos distintos: o avanço da frente distal de dunas eólicas de crista sinuosa, do tipo barcana, e a alternância entre deflação e cavalgamento subcrítico de marcas onduladas sobre superfícies deposicionais sub-horizontais. Estes processos podem ocorrer tanto em lençóis de areia na parte periférica de campo de dunas, quanto em planícies interdunares inundadas. A existência de água no ambiente de formação desta fácies é evidenciada pela presença de arenito maciço fluidificado, siltito esverdeado, laminações heterolíticas do tipo wavy e estruturas de sobrecarga. Considerando os processos formadores prováveis retromencionados, este último conjunto de feições pode representar a formação de lagos efêmeros em depressões topográficas, ou ainda em planícies interdunares, limitados por formas de leito eólicas (represamento de água por dunas e draas).

Fácies Aca (Arenito com estratificação cruzada de ângulo alto)

Arenito fino a médio com estratificação cruzada acanalada, com ângulo de mergulho médio a alto, entre $10^{\circ}$ e $30^{\circ}$ (Figuras 10 e 11). Superfícies de $3^{a}$ ordem repetem-se em intervalos decimétricos a métricos. Localmente, esta fácies pode exibir séries cuneiformes de estratificação cruzada tangencial na base e no topo, ou seja, sigmóide (Figura 11). Em escala de lâmina, observam-se marcas onduladas transladantes e lentes de fluxo granular, com gradação inversa ou normal entre as lâminas (pontos JT.03, SA.02, UV.03, GR.09, GR.10). 


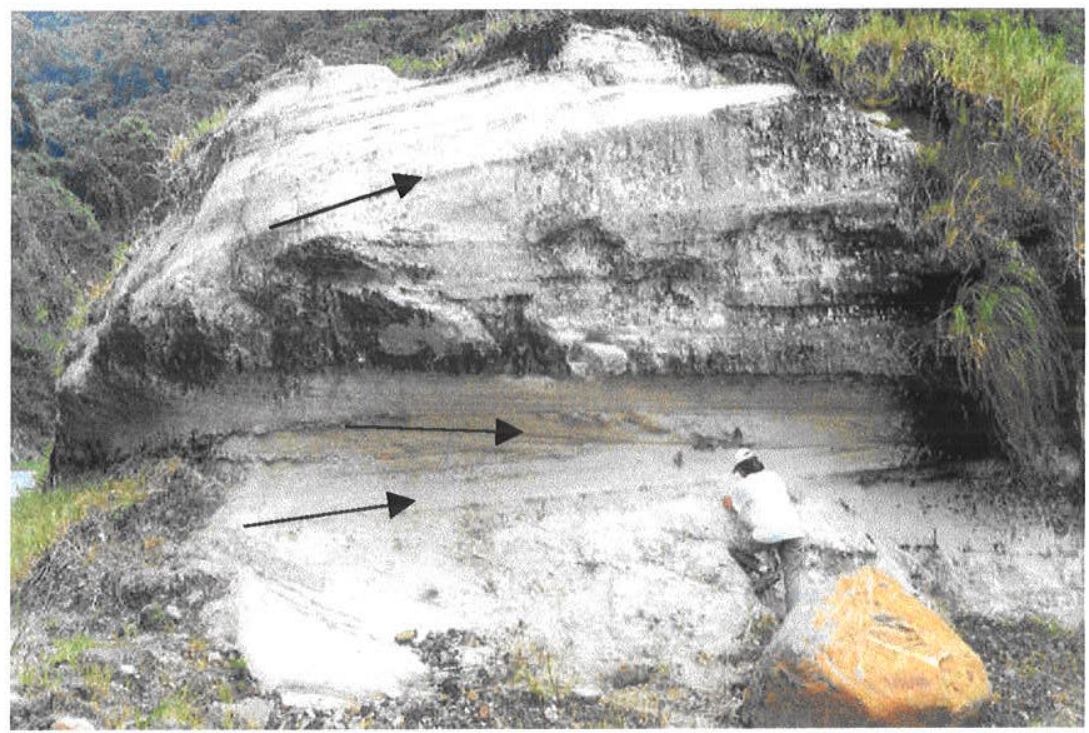

Figura 10 - Estratificação cruzada acanalada com superfícies de truncamento de $3^{\mathrm{a}}$ ordem que se sucedem em intervalos submétricos (setas). Foto do ponto GR.09, Formação Pirambóia inferior, folha de Guarapuava, região centro-sul do Paraná.

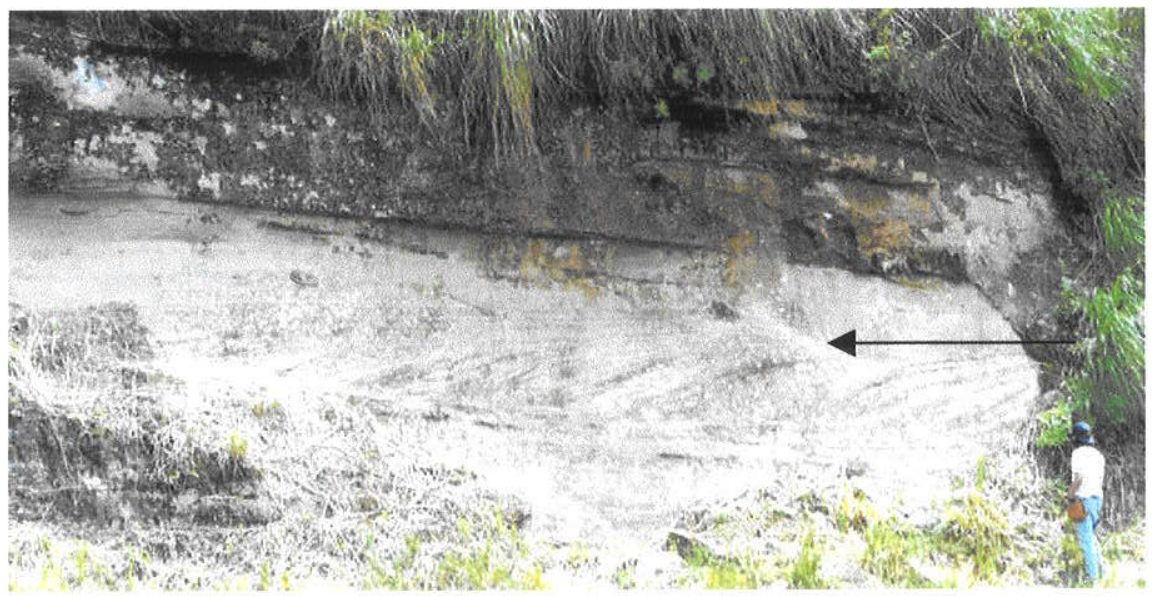

Figura 11 - Série de espessura métrica, cuneiforme, de estratificações cruzadas tangenciais na base e no topo (seta), sigmóides, de alto ângulo de mergulho. Ponto GR.09, Formação Pirambóia inferior, na região de Guarapuava, serra da Esperança, centro-sul do Paraná. 
A gênese da fácies Aca é atribuída à migração de dunas eólicas barcanas e a sucessão de séries desta fácies indica possivelmente o estabelecimento de campos de dunas barcanas ou barcanóides, cavalgantes. Já a presença constante de superfícies de $3^{a}$ ordem poderia ser associada a variações da direção de migração das dunas eólicas.

O aspecto maciço junto ao topo das séries, encontrado localmente dentro da fácies, pode ser explicado pela presença de fluidificação ou bioturbação. Qualquer um destes processos deve ter sido intenso o bastante para eliminar a maior parte das estruturas sindeposicionais. Em afloramentos bioturbados, a intensificação gradual de cor avermelhada em direção ao topo da fácies, até alcançar uma tonalidade anômala para a unidade, lembra os paleossolos descritos em paleodunas do Quaternário (Bigarella \& Becker 1975; Giannini 1993; Giannini 1998; Giannini et al. 1999a).

Fácies Acbl (Arenito com estratificação cruzada acanalada de baixo ângulo com lâminas pelíticas)

Arenito fino com estratificação cruzada acanalada de espessura variável entre centimétrica a submétrica, com ângulo de mergulho médio a baixo (menor que $15^{\circ}$ ). Superfícies de $3^{a}$ ordem são pouco aparentes. Ocorre laminação cruzada cavalgante subcrítica ou transladante, convolução suave (Figura 12) e laminação heterolítica incipiente e/ou descontínua, às vezes incluindo gretas de contração, filmes de lama estilolizados e flocos de lama esverdeados (metade superior da figura 13) ou avermelhados, encurvados (pontos UV.02, UV.03, MS.06, MS.07, IV.05, IV.07(II), IV.08, IV.11, JC.02, GR.08 e SA.02).

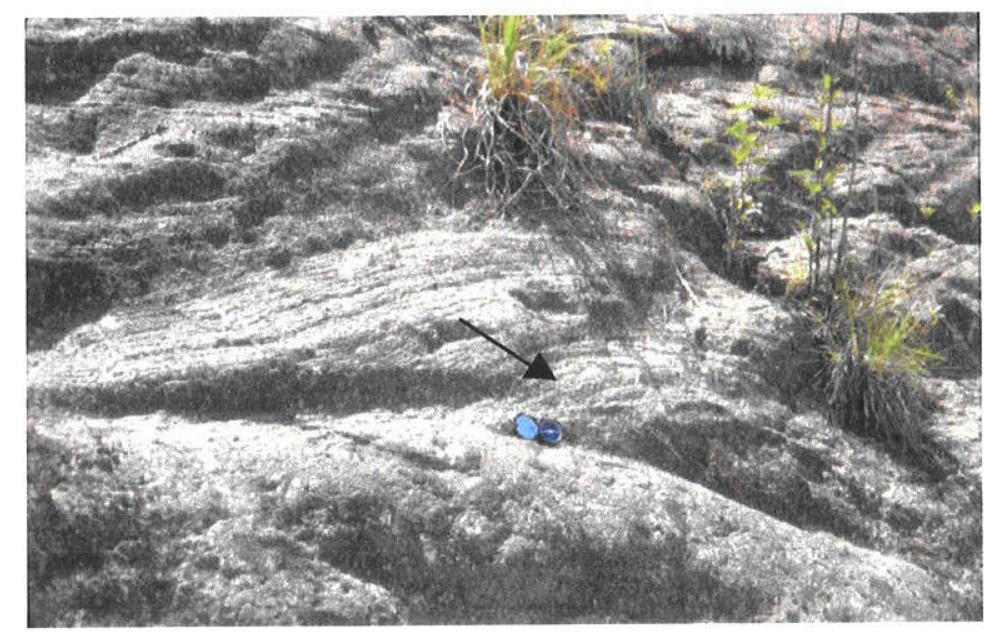

Figura 12 - Convolução suave (seta) em arenito fino da fácies Acbl. Foto do ponto UV.03, Formação Pirambóia inferior na região de União da Vitória, centro-sul do Paraná. 


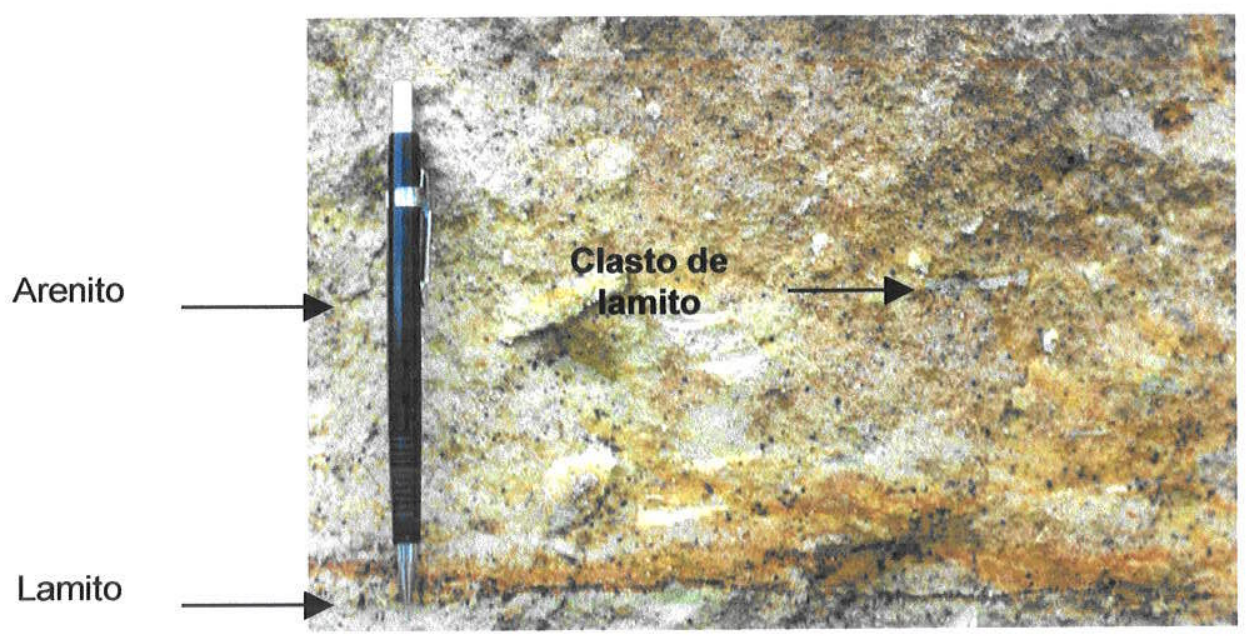

Figura 13 - Lamito com laminação muito fina (base da foto) recoberto por arenito fino com estratificação plano-paralela. Foto do ponto GR.08, metade inferior da Formação Pirambóia na serra do Cadeado, região centro-norte do Paraná. Notar clasto de lamito verde sub-horizontal dentro do arenito.

Esta fácies também representa o avanço de frentes de dunas eólicas barcanas. No entanto, a presença de estruturas indicativas de processos subaquosos efêmeros (laminação heterolítica e flocos de lama encurvados) e de fluidificação de areia (convolução suave) aponta para a ocorrência de inundação na interduna. A associação entre processos eólicos e processos subaquosos efêmeros sugere que esta é uma fácies típica de interduna úmida. A cor avermelhada do lamito indica condições oxidantes, possivelmente eodiagenéticas. Já gretas de contração e clastos achatados de lama representariam exposição subaérea, seguida por transporte trativo subaquoso, em regime de fluxo inferior, e por deformação hidroplástica.

Fácies ACc (Arenito conglomerático com estratificação cruzada acanalada de baixo ângulo e estruturas de corte e preenchimento)

Arenito fino a muito fino, siltoso, interlaminado a arenito médio a grosso com estratificação cruzada acanalada ou planar de baixo ângulo de mergulho. Exibe séries de pequeno porte, inferiores a $0,3 \mathrm{~m}$. As séries podem apresentar intraclastos de lama esverdeada, subarredondados a angulosos, de até $15 \mathrm{~cm}$ de diâmetro, às vezes com encouraçamento por seixos e grânulos arredondados de quartzo e quartzito. Pode-se observar nos intraclastos everdeados laminação proeminente. Os clastos de lama podem ocorrer dispersos de modo caótico ou em aglomerações. Localmente a fácies pode exibir 
laminação cruzada acanalada de baixo ângulo ou estratificação plano-paralela, afetada por convoluções suaves. Encontraram-se também marcas de sola e feições de corte e preenchimento.

A presença de clastos de lama em matriz arenosa fluidificada, sugere retrabalhamento destes (Figuras 14 e 15), possivelmente ainda inconsolidados, sendo as planícies interdunares subaquosas a área fonte provável. As estruturas sedimentares desta fácies apontam para a ocorrência de processos subaquosos trativos. Este caráter subaquoso trativo erosivo e a estreita relação com fácies eólicas permitem interpretar a fácies como formada por enxurradas episódicas, confinadas nas regiões interdunares. As enxurradas poderiam ser ocasionadas por inundação efêmera, típica de rios entrelaçados de deserto (oueds).

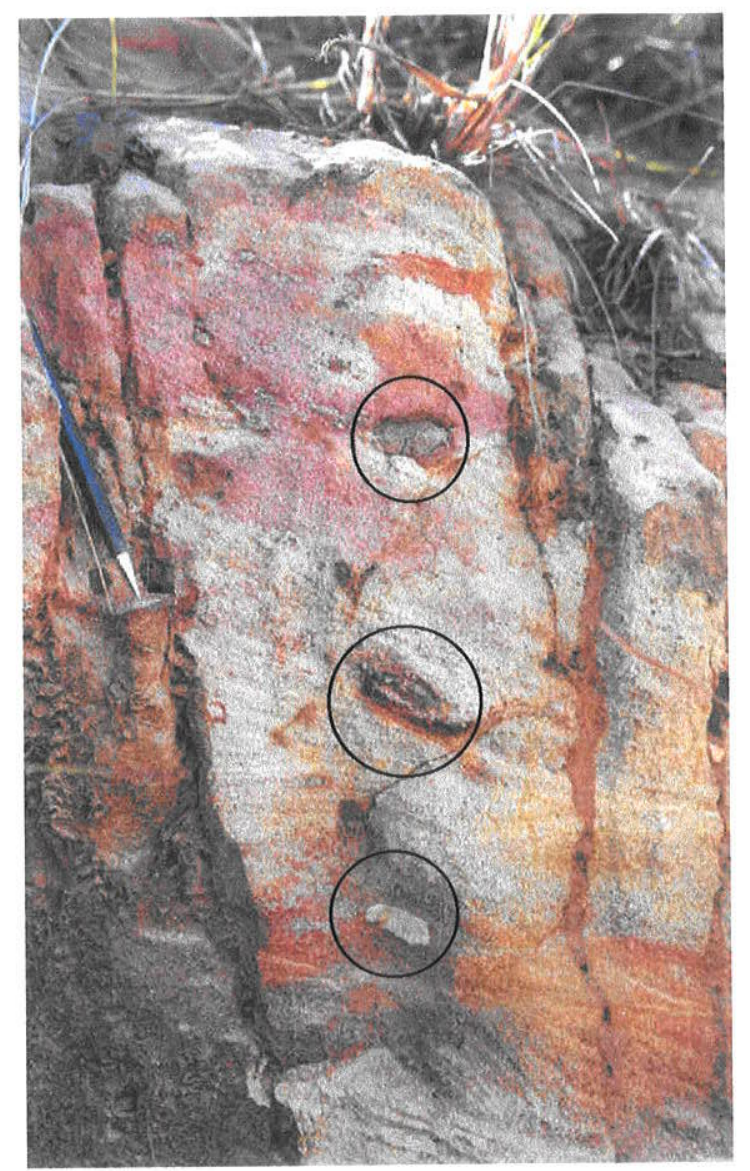

Figura 14 - Arenito fino com intraclastos tablóides a angulosos (círculos), acompanhando plano de estratificação cruzada acanalada de ângulo alto, cerca de $25^{\circ}$. Foto do afloramento SA.02, Formação Pirambóia superior na região de Santo Antônio da Platina, norte do Paraná. 


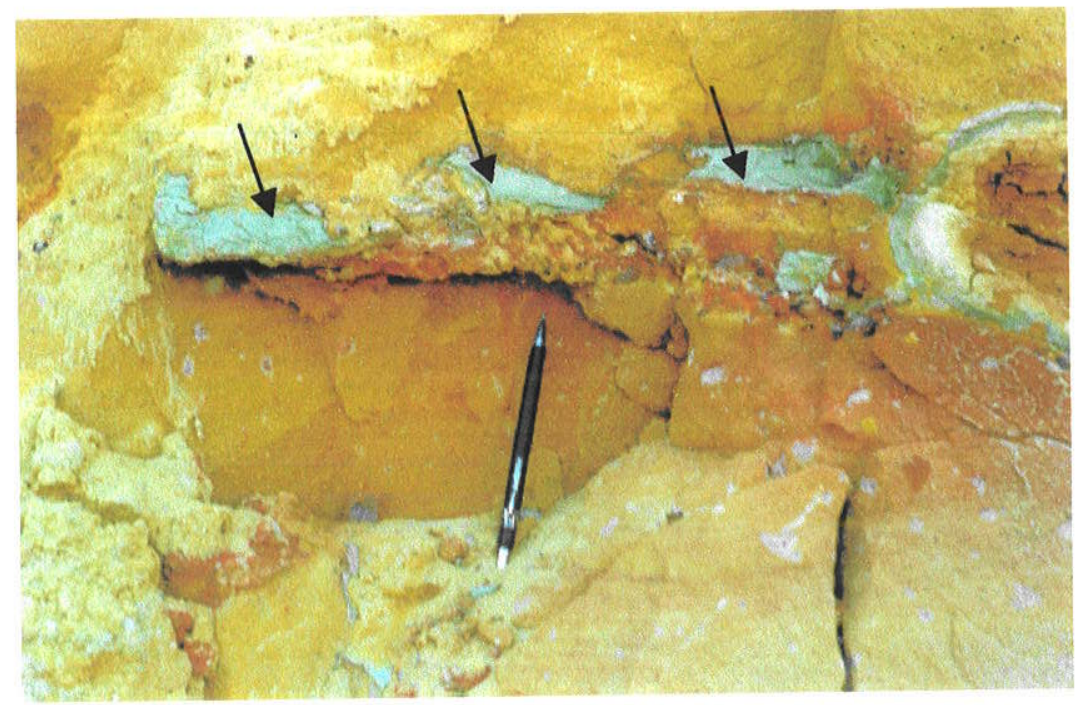

Figura 15 - Arenito fino com clastos de lamito subarredondados a angulosos (setas), tablóides a esferoidais, preenchendo estrutura de corte em arenito com estratificação cruzada de baixo ângulo. Foto do afloramento UV.02, Formação Pirambóia superior, na região de União da Vitória, sul do Paraná.

Fácies $\mathbf{A C g}$ (Arenito conglomerático a conglomerado com estratos gradados)

Arenito muito grosso a fino, na maioria dos casos com grânulos e seixos de quartzo e/ou quartzito, que podem acompanhar ou não séries de estratificação cruzada acanalada (Figura 16 a 18). Estas séries atingem espessura de no máximo $1 \mathrm{~m}$, entretanto, séries de estratificação cruzada planar tendem a ter espessura máxima menor $(10 \mathrm{~cm})$, com segregação de seixos e grânulos nas frentes de deslizamento (foreset) das formas de leito (pontos UV.02, GR.10, GR.11, RP.08, SA.02, SA.16, JT.04, MS.07, MS.12 e IV.05). Localmente pode-se observar areia grossa com estruturas heterolíticas (Figura 19).

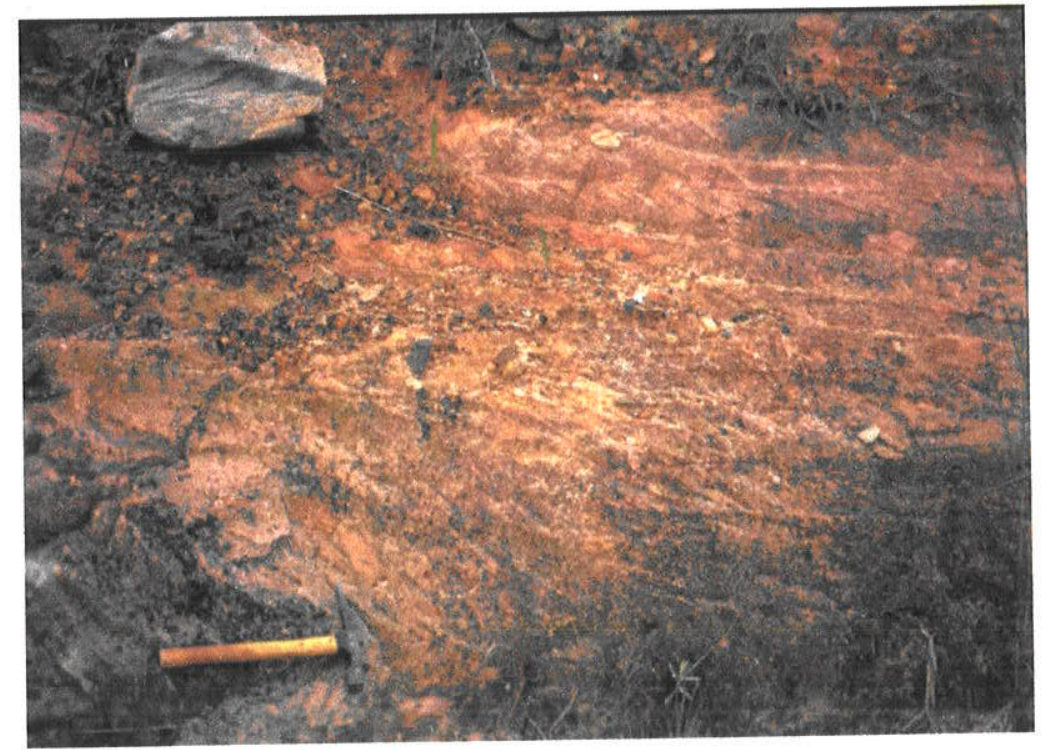

Figura 16 - Arenito médio a grosso com seixos e grânulos de quartzo e quartzito acompanhando as laminações cruzadas planares. Atribui-se a formação destas a barras transversais. Foto do ponto MS.07, Formação Pirambóia superior na serra do Cadeado, região de Mauá da Serra, centro46 norte do Paraná. 


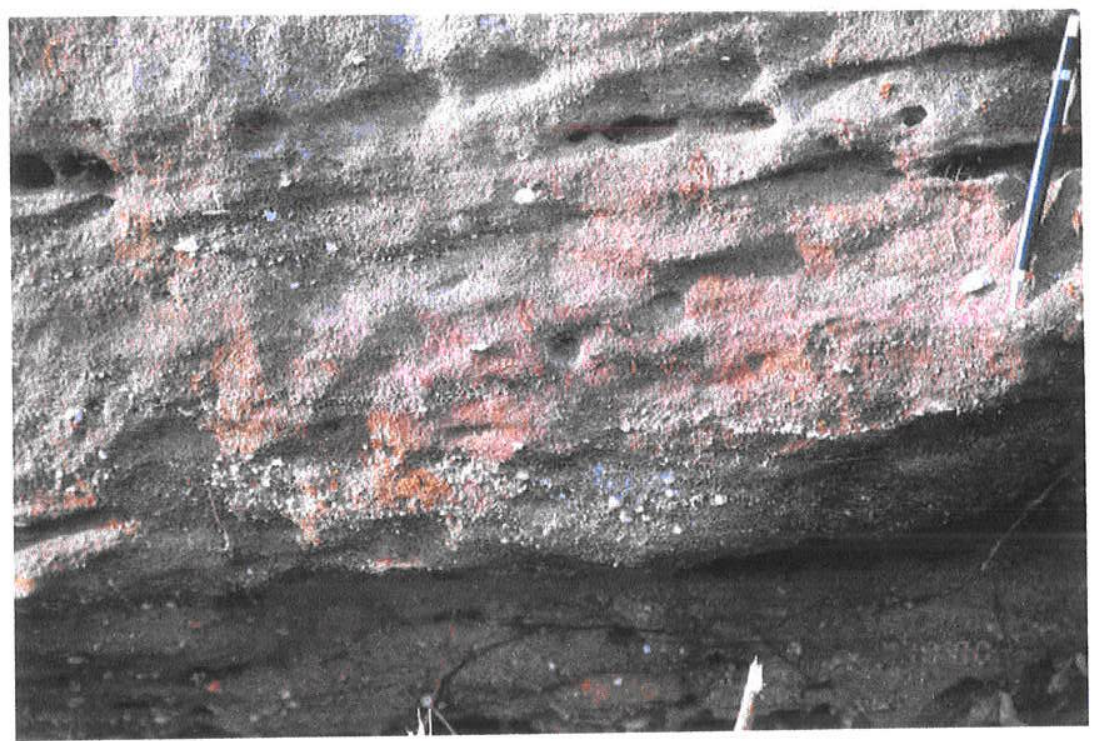

Figura 17 - Arenito grosso conglomerático, com seixos e grânulos de quartzo e quartzito, subangulosos. Os seixos podem acompanhar planos de estratificação cruzada acanalada, ou dispor-se em aglomerações, compondo níveis aparentemente lenticulares de espessura centimétrica. Foto do ponto IV.03, metade superior da Formação Pirambóia, região centro-norte do Paraná.

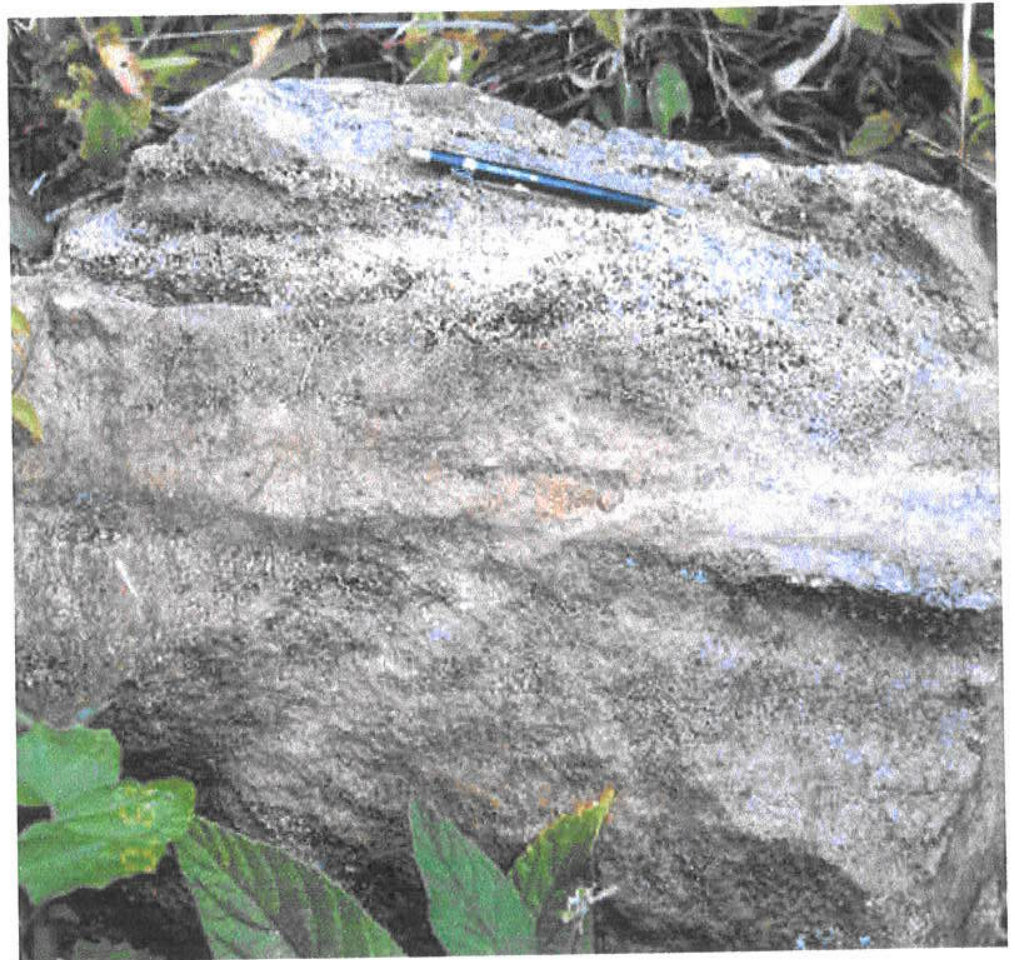

Figura 18 - Intercalação de níveis aparentemente lenticulares de arenito grosso a arenito muito grosso, conglomerático. Os seixos e grânulos são compostos por quartzo e quartzito arredondados a subarredondados, atribuídos a barras transversais de oueds, rios de deserto. Foto do ponto MS.07, Formação Pirambóia superior na serra do Cadeado, região centro-norte do Paraná. 


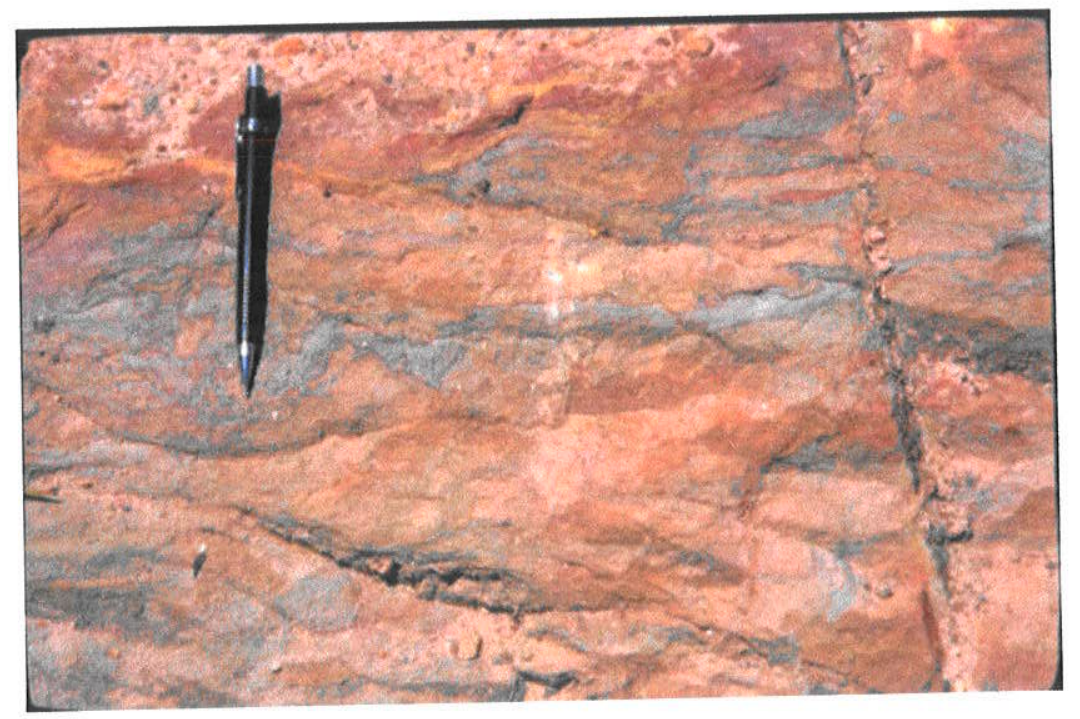

Figura 19 - Laminação heterolítica deformada alternando arenitos médios a grossos com siltitos de coloração roxa. Foto do ponto IV.05, Formação Pirambóia superior, folha de Ivaiporã, região centro-norte do Paraná.

A fácies $\mathrm{ACg}$ representa possivelmente depósitos de rios entrelaçados, típicos de regiões desérticas (oueds), com barras transversais de porte centimétrico. Algumas séries espessas (métricas) de granulometria mais fina (areia média a fina) poderiam representar dunas transversais isoladas em ampla planície interdunar, com presença de água nas interdunas. A presença de água em sedimentos de arcabouço aberto, incoeso, seria responsável pelo registro de deformação hidroplástica encontrada nas séries de estratificação acanalada.

Fácies Afca (Arenito fino a muito fino com estratificação cruzada de alto ângulo)

Arenito fino a muito fino, com séries de estratificações cruzadas acanaladas milimetricamente laminadas de extensão decamétrica e espessura média de $3 \mathrm{~m}$. São observadas superfícies de $2^{a}$ ordem, apesar do tangenciamento das estratificações cruzadas sobrepostas aparentar localmente hierarquia de $3^{\text {a }}$ ordem (Figuras 20 e 21). Séries de espessura submétrica e geometria acanalada alternam-se com séries maiores com acanalamento menos nítido e maior ângulo de mergulho das estratificações cruzadas. Pode-se observar a ocorrência de lentes descontínuas de fluxo granular subcentimétricas a centimétricas (até $3 \mathrm{~cm}$ ), às vezes com gradação inversa visível. Esta fácies repete-se monotonamente em toda a Formação Botucatu e nos arenitos intertrapp da Formação Serra Geral (JC.01, JC.07, JC.09, JC.12, SA.03, SA.04, SA.15, IP.01, 
UV.02, GR.11, GR.12, GR.13). Representaria o avanço de dunas barcanas ou cadeias barcanóides e draas, em contexto de campo de dunas seco.

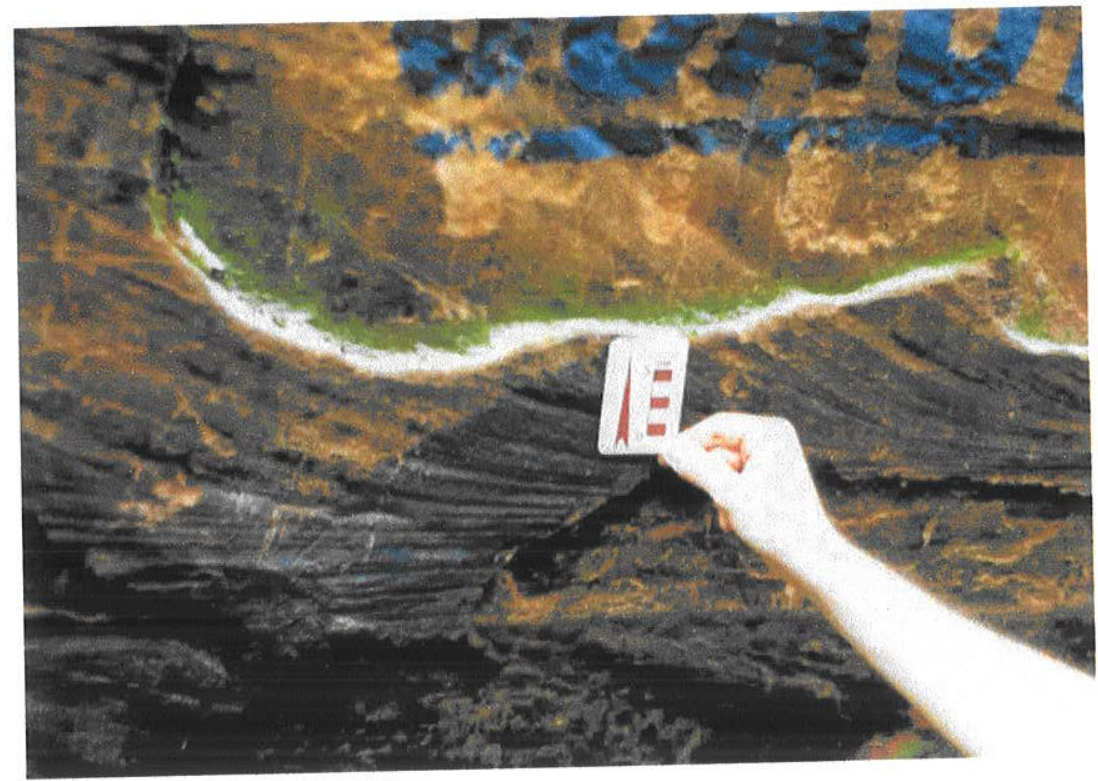

Figura 20 - Arenito com estratificação cruzada tangencial na base, de alto ângulo de mergulho, $15^{\circ}$, com alternância entre lentes de queda e fluxo de grãos. Ponto JC.01, Formação Botucatu superior, proximidades do rio Paranapanema, entre os estados de São Paulo e Paraná.

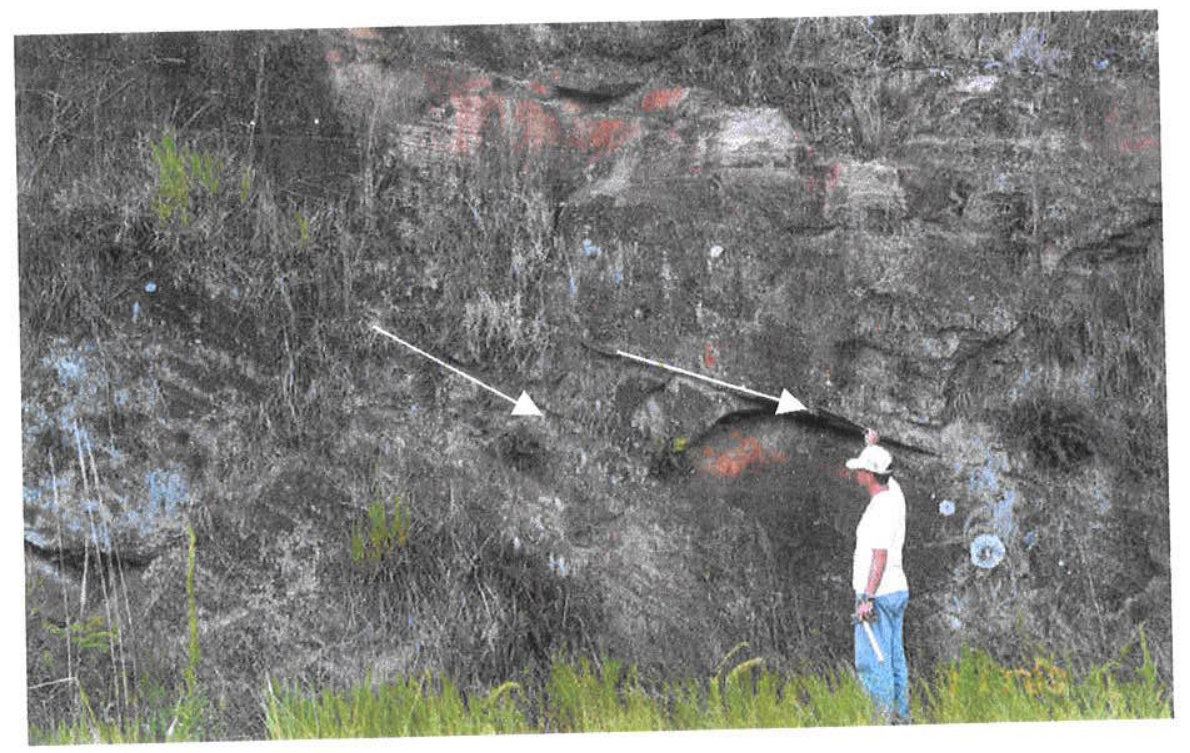

Figura 21 - Arenito com estratificação cruzada acanalada de alto ângulo de mergulho. Notar sucessão de superfícies de $3^{\mathrm{a}}$ ordem em intervalos métricos (setas). Foto do ponto IV.01, Formação Botucatu superior na região de Ivaiporã, centro-norte do Paraná. 
Fácies Afcb (Arenito fino a muito fino com estratificação cruzada de ângulo baixo)

Arenito fino a muito fino com estratificação cruzada acanalada de ângulo inferior a $10^{\circ}$, formando séries métricas lenticulares, descontínuas lateralmente, com laminação fina (milimétrica) determinada por segregação granulométrica (Figuras 22 e 23). Marcas onduladas assimétricas de crista reta ocorrem com freqüência, sobre superfícies de estratificação cruzada acanalada (Figuras 24 e 25). Encontrou-se bioturbação semelhante ao icnogênero Taenidium, porém de menor porte (tubo milimétrico), sem meniscos ou qualquer outra estrutura interna. Embora não seja incomum, esta fácies é de difícil individualização devido à sua passagem transicional para a fácies Afca, mas é bem desenvolvida em alguns afloramentos do contato entre as formações Botucatu e Pirambóia (MS.12, SA.03, SA.04, SA.15, SA.19, UV.02, GR.11 e GR.14).

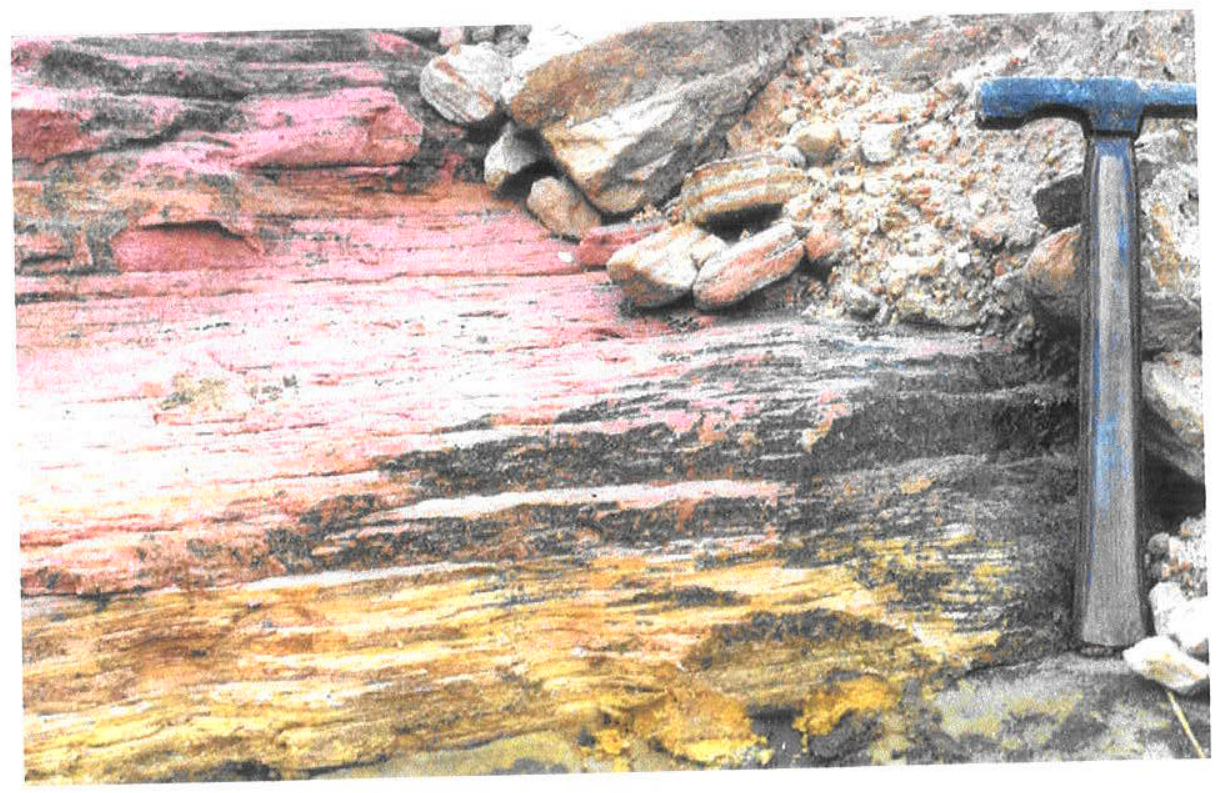

Figura 22 - Arenito fino com estratificação cruzada acanalada de baixo ângulo de mergulho e laminação plano-paralela. Formação Botucatu inferior, ponto UV.02, em pedreira próxima a União da Vitória, região sul do Paraná. 


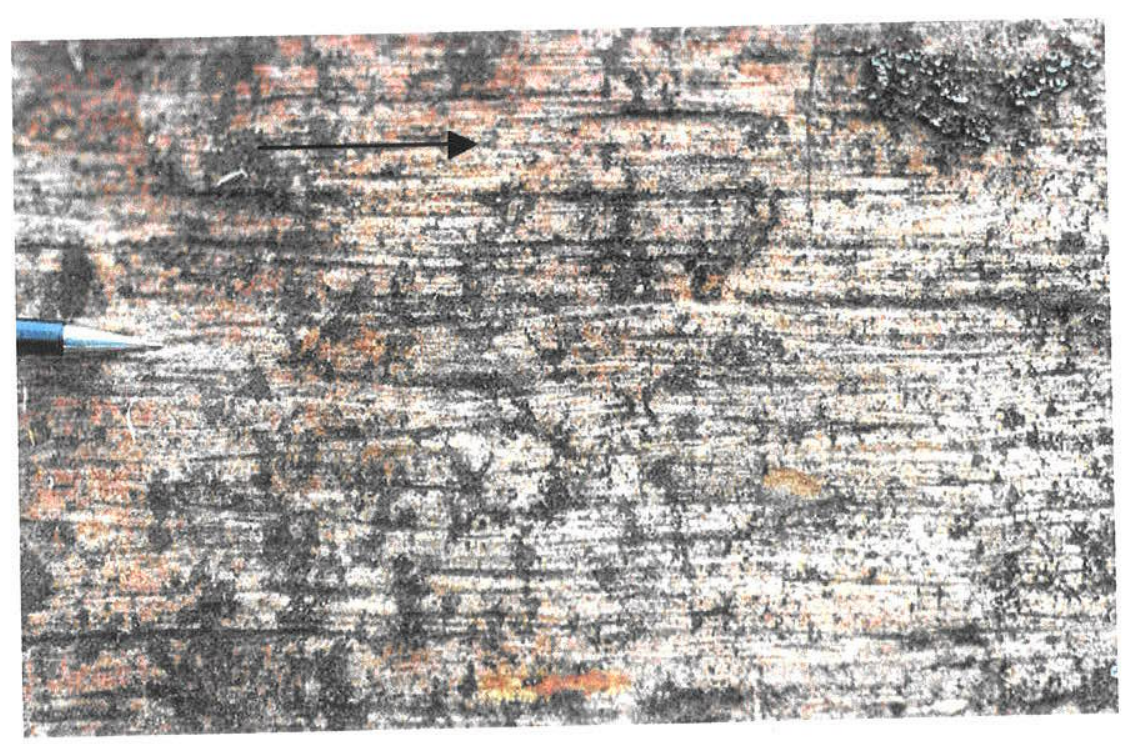

Figura 23 - Marcas onduladas cavalgantes subcríticas (ponta da lapiseira) ou transladantes (seta) . Constituem laminação fina, desenvolvida junto ao contato basal da Formação Botucatu, imediatamente acima do contato com a Formação Pirambóia. Foto do ponto GR.11, região de Guarapuava, centro-sul do Paraná.

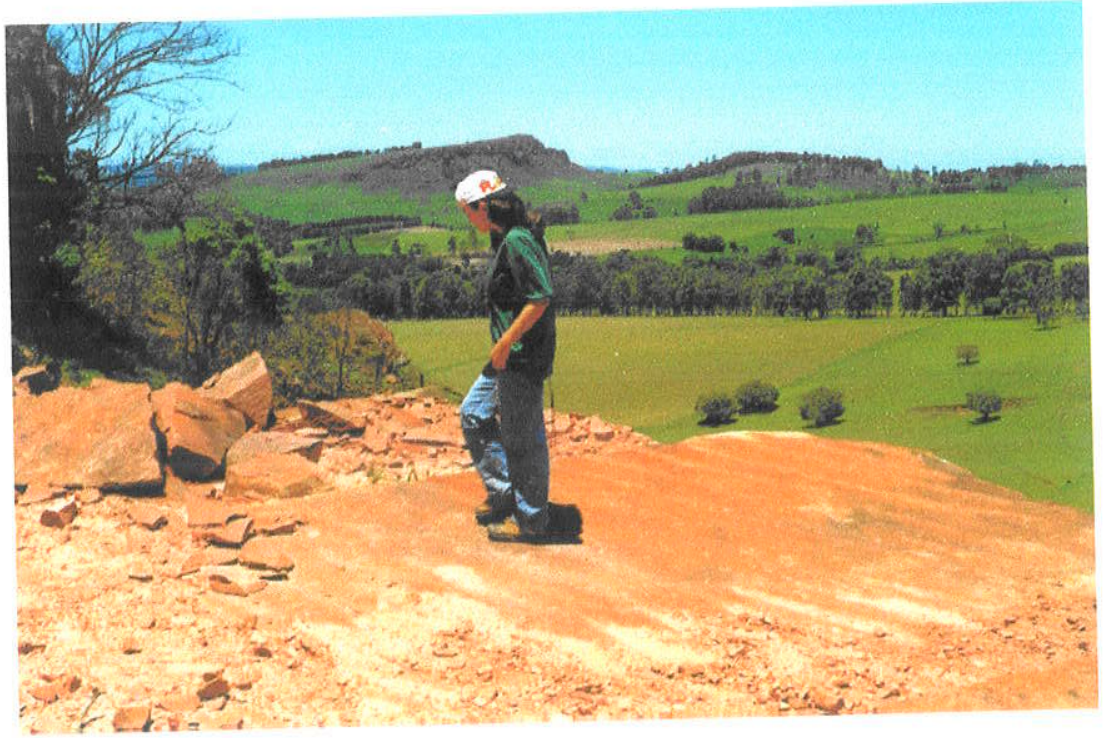

Figura 24 - Marcas onduladas assimétricas aplainadas, de crista reta sobre plano de estratificação cruzada acanalada com ângulo baixo, menor que $10^{\circ}$. Foto do ponto IP.01, Formação Botucatu, próximo a Ribeirão Claro, PR, e Ipauçu, SP, região norte do Paraná. 


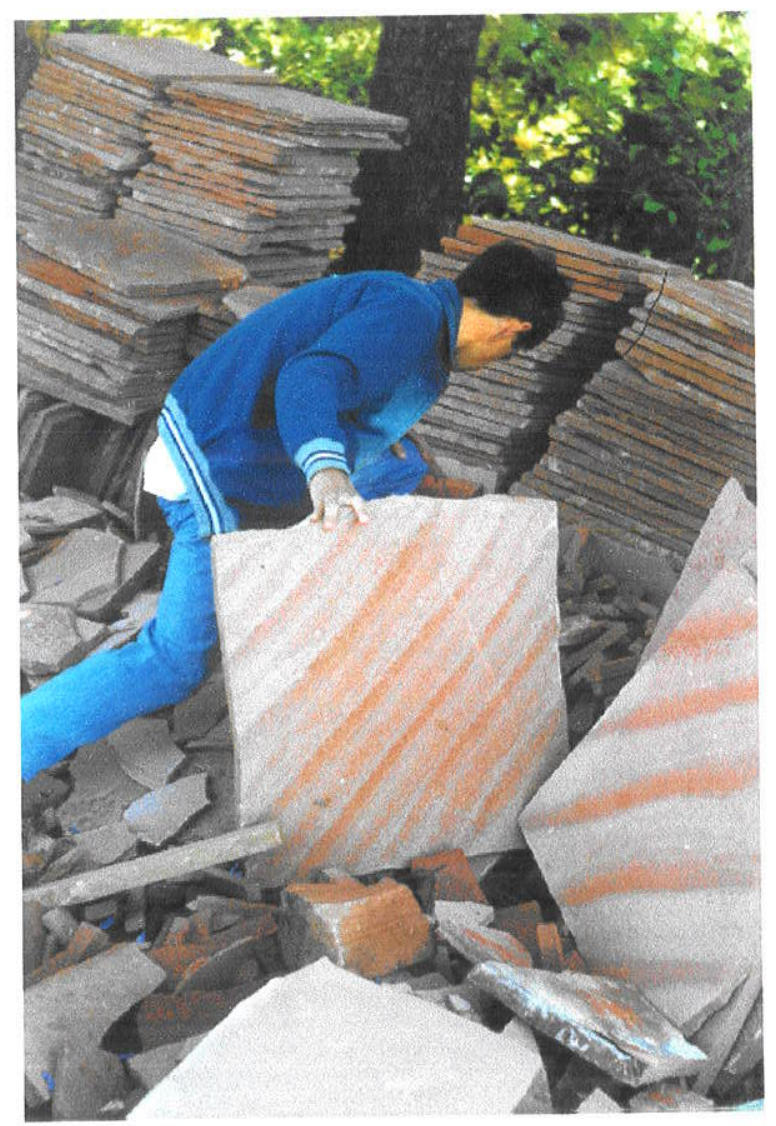

Figura 25 - Lajes de arenito silicificado exibindo, em planta, as marcas onduladas de crista reta da foto anterior. Pedreira em Ribeirão Claro, região norte do Paraná, PR.

Fácies Afcd (Arenito fino com estratificação cruzada acanalada de alto ângulo deformada)

Arenito fino a muito fino, em série de espessura métrica de estratificação cruzada acanalada de ângulo alto (maior que $20^{\circ}$ ), apresentando laminação subcentimétrica a centimétrica, de fluxo granular, intensamente dobrada e/ou falhada (Figura 26). Nas porções inferiores das séries com estratificação cruzada, ocorre laminação cruzada cavalgante com azimute de mergulho reverso e estratificação convexa para cima, apresentando dobras de comprimento métrico e amplitude centimétrica $(\sim 25 \mathrm{~cm})$ truncadas por superfícies de $3^{\mathrm{a}}$ ordem de ângulo de mergulho mais alto (cerca de $25^{\circ}$ ). $\mathrm{Na}$ região de Piraju, SP, a deformação atinge um pacote de arenitos com estratificação cruzada com mais de $5 \mathrm{~m}$ de espessura, chegando a ocorrer dobras decimétricas fechadas. Esta fácies pode passar lateralmente para a fácies Afca, com icnofósseis (tubos de Taenidium).

A fácies Afcd corresponderia a depósitos de escorregamento de areia úmida na frente de dunas barcanas. As estruturas sedimentares que manifestam reologia rúptil 
(brechóides) relacionam-se com torrões de areia úmida na parte superior e mais íngreme das frentes de deslizamento das formas de leito, fragmentados pela ação de ventos reversos combinados com a distensão exercida pela componente tangencial da força peso. As estruturas de deformação plástica (dobras suaves) relacionam-se à compressão exercida pela mesma componente na base das frentes de deslizamento. Modelos atuais para estes processos, com formação de estruturas análogas, têm sido encontrados em dunas costeiras da costa catarinense (Giannini 1993; Giannini et al. 1999). A umidade aí deriva de chuvas associadas a ventos reversos de frentes frias. Na Formação Botucatu, as duas explicações mais plausíveis para a umidade da areia são chuvas episódicas ou ação intermitente de nevoeiros úmidos noturnos (fenômeno descrito por McKee (1963) em desertos modernos).

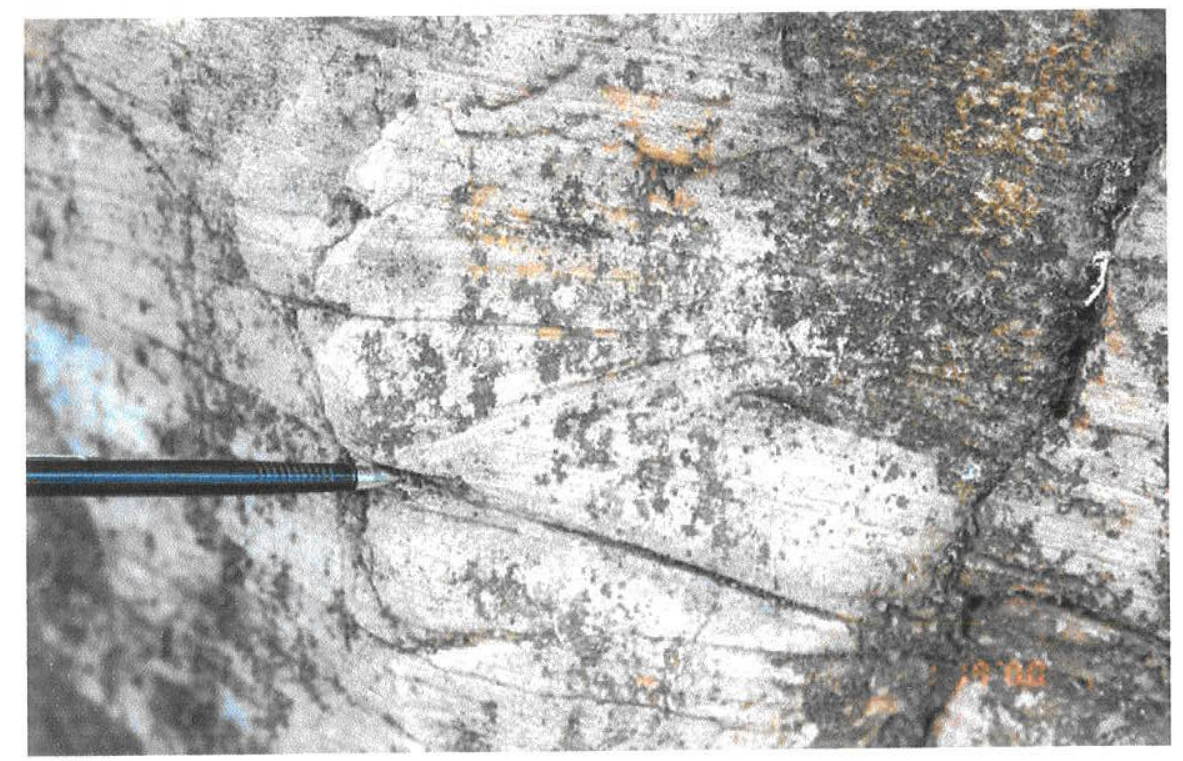

Figura 26 - Arenito médio a fino com estratificação cruzada acanalada de alto ângulo de mergulho, maior que $10^{\circ}$, com deformação penecontemporânea a sedimentação. Foto do ponto MS.03, pertencente ao topo da Formação Botucatu na região de Mauá da Serra, centro-norte do Paraná.

\subsection{Modelo genético integrado}

\subsubsection{Associações de fácies}

Os depósitos da sucessão psamítica Pirambóia-Botucatu foram subdivididos em quatro associações de fácies maiores, com posicionamento estratigráfico distinto (Sawakuchi 2000; Donatti et al. 2001). As três primeiras associações (A, B e C) 
correspondem a depósitos correlacionáveis em grande parte à Formação Pirambóia, da literatura litoestratigráfica, incluindo sua passagem transicional com o Grupo Passa Dois, e a última associação (D) pertencente à Formação Botucatu. Da base para o topo, as associações são as seguintes:

\section{Associação A: Lençol de areia}

A associação A é formada por arenitos e, subordinadamente, por lamitos. Inclui depósitos com laminação heterolítica ou de aspecto maciço da fácies Acbl e com estratificações cruzadas acanaladas de ângulo baixo, menor de $10^{\circ}$, da fácies $\mathrm{Acb}$. $\mathrm{A}$ espessura estimada seria de pelo menos $10 \mathrm{~m}$, com contato transicional das fácies de intercalação rítmica entre arenitos e lamitos do Grupo Passa Dois (Formação Terezina ou Rio de Rasto) e as fácies predominantemente arenáceas da Formação Pirambóia.

A associação inicia-se na base por uma intercalação irregular entre camadas decimétricas de bancos arenosos finos e clastos tabulares milimétricos de lamito, dispersos internamente ao arenito. As camadas seguem-se sobrespostas por crescimento da areia para o topo, em quantidade e em espessura. Em Mauá da Serra, PR, região da serra do Cadeado, elas constituem uma sucessão de fácies em que os depósitos deltaicos Morro Pelado, logo abaixo das fácies Acb e/ou Acbl, são encobertos de modo brusco por depósitos de dunas eólicas (fácies Aca, da associação B). A exemplo da fácies Acb, a fácies Acbl pode ser interpretada como registro da primeira deposição de lençóis de areia eólica sobre a superficie úmida da planície de maré, com fonte potencial de aporte terrígeno, associado aos paleo deltas Morro Pelado. E apesar do contraste textural do contato, a deposição do arenito é considerada penecontemporânea à deposição do lamito, evidenciado pela presença extensiva de estruturas de sobrecarga milimétricas a submétricas e fluidificação associada.

Conclui-se que a associação de fácies $A$ registra os episódios iniciais de instalação da deposição eólica Pirambóia. Seu contato transicional com os depósitos do Mar Passa Dois indica que a deposição de areias eólicas iniciou-se próximo à paleocosta. A própria dificuldade em se delimitar com exatidão onde termina a deposição deltaica e aonde inicia a deposição eólica é um argumento sugestivo de interdigitação entre os dois sistemas deposicionais. 
Esta associação encontra-se logo acima da associação A. Envolve as fácies Aca, Acb, ACc e Acbl. As fácies eólicas são representadas por depósitos de dunas e interdunas (Aca e Acb), fluidificados, enquanto que as fácies subaquosas são depósitos de rios efêmeros (oueds) e interdunas subaquáticas (ACc e Acbl). Esta associação corresponde a um sistema eólico bem desenvolvido, sob influência constante da água. Admitida a premissa de que a deposição eólica da Formação Pirambóia iniciou-se em condições evaporíticas próximo à costa do Mar Passa Dois, como indicado pela presença de evaporitos silicificados na associação A em São Paulo (Mattos 1995; Giannini 2001; Donatti et al. 2001), ou por dobras enterolíticas e nódulos encontradas no norte do Paraná, em Santo Antônio da Platina (Figuras 27 e 28, a seguir) seria razoável atribuir a presença de umidade no sistema ao nível freático relativamente elevado. Logo, esta associação pode ser considerada como representativa de um sistema eólico com eventual influência de deposição subaquosa costeira.

A bioturbação por tubos pôde ser descrita em depósitos de interdunas, entre Jacarezinho, PR, e Ourinhos, SP. Outra estrutura comum é a fluidificação, o que sugere tratar-se de arenitos de arcabouço aberto, embebidos em água e ainda incoesos durante os processos de deformação hidroplástica.

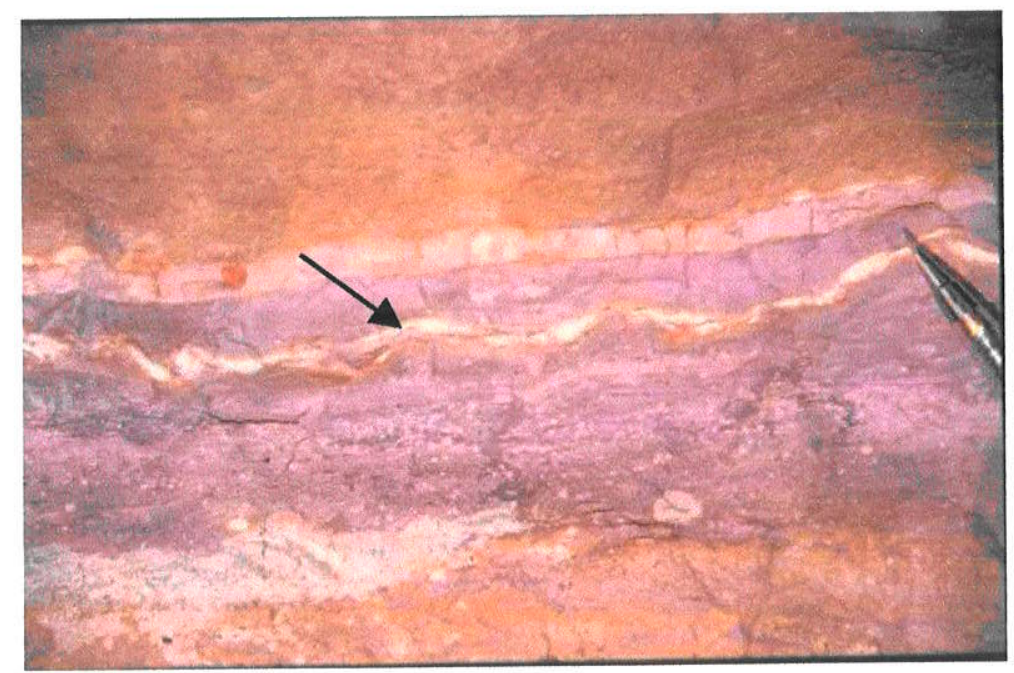

Figura 27 - Dobras enterolíticas, em silexito (seta), em meio a lamito (roxo) do Grupo Passa Dois na região norte do Paraná, município de Santo Antônio da Platina. 


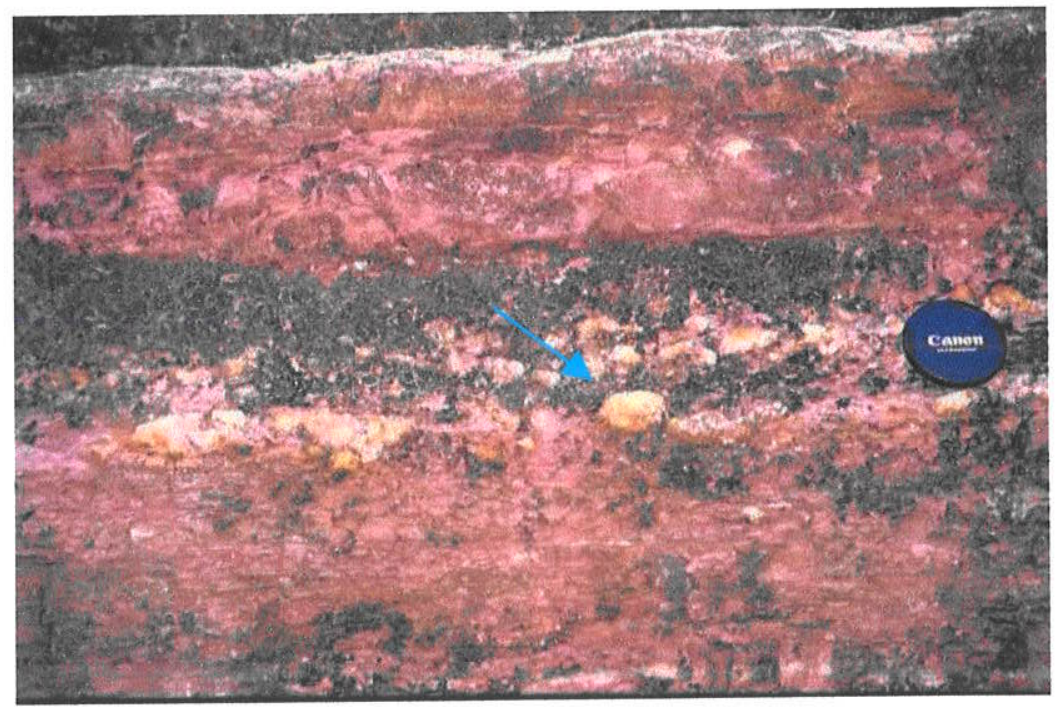

Figura 28 - Nódulos silicificados (seta) possivelmente gerados em condições eogenéticas evaporíticas, em lamito (roxo) do Grupo Passa Dois, na região norte do Paraná, município de Santo Antônio da Platina.

\section{Associação C: Fluvial}

A associação $C$ ocorre na porção superior do sistema eólico úmido, sendo caracterizada por depósitos de enxurradas ocasionadas sob regime de chuvas temporárias, o que permitiria a instalação de rios entrelaçados efêmeros (fácies $\mathrm{ACg}, \mathrm{ACc}$ e Acbl) com raras intercalações de arenitos eólicos (Aca e Acb). Esta associação apresenta significado estratigráfico regional, pois foi encontrada em todas as regiōes estudadas onde pôde ser observado o contato entre as formações Pirambóia e Botucatu.

A associação $C$ recobre os depósitos de dunas e interdunas, encontrando-se as fácies fluviais compostas por arenito grosso a conglomerado, sem, contudo, exibir em escala de afloramento, feiçőes erosivas de grande porte. Estruturas de barras longitudinais e/ou transversais, canais e mesmo feições típícas de planícies de inundação, quando encontradas, apresentam-se em escala centimétrica a submétrica.

A geometria relativamente plana da superfície sobre a qual se desenvolveu o sistema fluvial, em conjunto com a pequena expressão das entidades morfológicas, típicas do sistema fluvial, permite inferir a existência de canais de pequena espessura e grande continuidade lateral. $\mathrm{O}$ que leva a crer na existência de um pequeno potencial de erosão do substrato, e da atuação de processos trativos subaquosos de baixa energia. Portanto, é até possível admitir que a instalação de rios entrelaçados em ampla região 
deva marcar mudanças significativas na paleogeografia regional mas não necessariamente em toda a bacia. Talvez por isso a representatividade do sistema fluvial no Paraná seja mais expressiva que a detectada em São Paulo por Sawakuchi (2000).

\section{Associação D: Campo de dunas seco}

$A$ associação de fácies $D$ engloba a interdigitação monótona entre as fácies Afca, Afad e Afcb, com predomínio da primeira. Separa-se da associação D por uma superfície com caráter aparente de deflação, e ocorrência regional. Representa depósitos gerados pela migração de dunas e draas em campo de dunas secos. No topo, é delimitada por derrames de lava que recobriram dunas eólicas inconsolidadas e diminuíram o suprimento de areia ao sistema eólico, determinando assim o início de seu desfecho.

\subsubsection{Tipos de sistemas deposicionais}

A sucessão de associações de fácies dos sistemas deposicionais Pirambóia e Botucatu pode ser entendida como manifestação da dinâmica dos sistemas. A distinção entre fácies ou associações de fácies eólicas baseia-se na caracterização de tipos morfológicos de dunas e na morfologia e constituição das interdunas (Fisher 1983). Soares (1992) considera as fácies eólicas da Bacia do Paraná como registros de entidades morfológicas. No Quaternário costeiro, uma faciologia fundada em tipos morfológicos tem permitido compreender muitos aspectos da dinâmica do sistema (Giannini 1993; 1997; Carvalho \& Giannini 1998).

São os saldos entre entradas e saidas de sedimentos que determinam os tipos morfológicos e as dimensões de dunas e interdunas (fácies), os quais podem interligar-se, superpor-se ou fundir-se, chegando a gerar novas formas em hierarquias superiores de escala (associações de fácies). Estes saldos sedimentares dependem da disponibilidade de sedimentos nas áreas-fontes e da energia eólica para movê-los (Giannini 1993). Disponibilidade e energia confundem-se ai com os conceitos de influxo e efluxo de sistemas eólicos, na acepção de Kocurek \& Havholm (1993).

Segundo Giannini $(1993 ; 2001)$ a disponibilidade de areia incoesa é controlada pela intensidade de participação da água no sistema. $O$ transporte subaquoso seria também o principal fator de quebra da exclusividade de ação do agente eólico, principalmente nas fácies interdunares e deflacionares. Nestas fácies, segundo aquele autor, a proximidade e frequêencia da presença de água é um fator de diversificação faciológica do sistema. É o 
que se verifica nos sistemas eólicos úmidos. Nos campos dunares de desertos amplos e estabelecidos, com influência extremamente remota da água e da vegetação, a distinção de fácies restringe-se ao reconhecimento de formas e dimensões de dunas, o que demandaria uma análise de superfícies de truncamento que as dimensões dos afloramentos raramente permitem. A presença exclusiva de depressōes interdunares, devido ao entulhamento das planícies interdunares, dificulta sobremaneira a distinção entre fácies de dunas e de interdunas. É o caso típico de sistemas eólicos secos.

A dinâmica de um sistema deposicional eólico está intimamente relacionada à presença de água $e$, portanto, ao comportamento do nível freático (Kocurek \& Havholm 1993). O nível freático atua como nível de base da erosão e controla a disponibilidade de sedimentos aptos a serem retrabalhados pelo vento. Em um sistema eólico úmido costeiro, variações de maior amplitude do nível freático estariam relacionadas possivelmente a variações do nível do mar adjacente.

A abundância de fácies de dunas incipientes de planícies interdunares úmidas ou afogadas na Formação Pirambóia caracteriza um sistema deposicional eólico úmido. $O$ ambiente geoquímico, entretanto, envolveria condições evaporíticas, indicadoras de clima árido a semi-árido, desde o final da sedimentação Passa Dois. Na Formação Terezina, estas condições são indicadas pela presença de oóides fibro-radiados com elevado teor de $\mathrm{Sr}$ (até $650 \mathrm{ppm}$ ), níveis de gipso nodular silicificado a quartzina (Coimbra \& Giannini 1989; Sawakuchi 2000), sílica pseudomorfa de cristais centimétricos de gipso com hábito em espada e laminitos fenestrais (Sawakuchi 2000). Na Formação Pirambóia, a principal evidência de condições evaporíticas é a ocorrência de paligorskita, encontrada como cimento de arenitos próximo ao topo da unidade.

Havendo condições evaporíticas, a umidade e o nivel freático alto que influenciaram o desenvolvimento do sistema Pirambóia só podem ser atribuídos à proximidade da costa (Sawakuchi 2000; Giannini 2000; Donatti et al. 2001). Cabe ressaltar que as associações de fácies da Formação Pirambóia, bem como as relações de contato transicionais com as unidades sotopostas do Grupo Passa Dois, permitem associá-la a um sistema eólico úmido costeiro. Com base nessa premissa, as associações A, B e C representariam respectivamente: A) Instalação de um sistema eólico úmido costeiro no Pirambóia próximo à costa do Mar Passa Dois. B) Estabelecimento de campo de dunas, ainda próximo da costa, com depressões e planícies interdunares alagadas devido a variações do nível do Mar Passa Dois e $\mathrm{C}$ ) Ápice da regressão do Mar Passa Dois, com dissecação fluvial em ampla área da bacia, representada por depósitos de rios entrelaçados intercalados a depósitos eólicos. A última 
associação, D, representaria o estabelecimento de campo de dunas eólicas, com pouca ou nenhuma influência de água, próximo ao desfecho da sedimentação eólica. É o registro do erg Botucatu, composto por depósitos de lençóis de areia, dunas barcanas e cadeias barcanóides e draas estrelados.

Esta sucessão de eventos confere caráter regressivo para os depósitos do sistema Pirambóia. Desta forma, poder-se-ia subdividi-lo em dois subsistemas (Sawakuchi 2000). O primeiro, representado pela associação $A$, corresponderia a um campo de dunas desenvolvido próximo à costa do mar Passa Dois. $O$ segundo, representado pelas associações típica de planície aluvial e fluvial $\mathrm{B}$ e $\mathrm{C}$, representaria o registro de um campo de dunas interior com interação fluvio-eólica nos estágios finais de desenvolvimento.

Em linhas gerais, e restringindo-se ao aspecto descritivo, uma variação vertical de faciologia similar ao empilhamento $A B C D$ já fora relatada por Soares (1973) em seções no estados de São Paulo e Paraná. O modelo adotado aqui para explicar este zoneamento faciológico-estratigráfico difere da hipótese de Soares (1973) por não considerar o sistema Pirambóia como de origem unicamente fluvial e por não admitir a discordância (com hiato deposicional) pré-Pirambóia. Neste último aspecto, difere também da de Caetano-Chang (1997).

A única associação de fácies reconhecida até agora no sistema Botucatu (Sawakuchi 2000; Giannini 2001; Donatti et al. 2001) distingue-se das associações do sistema Pirambóia pela inexistência de cruzadas de ângulo baixo enquanto fácies independente e bem delimitada. As estratificações de mergulho baixo $\left(<10^{\circ}\right)$ gradam, dentro da mesma série, para mergulhos altos. Não há, portanto, bom desenvolvimento de fácies interdunares/deflacionares, as quais devem encontrar-se pouco evidentes ao longo de superfícies de $1^{a}$ ordem (muito espaçadas e portanto raras em escala de afloramento) e de eventuais supersuperfícies (com areia sobre areia, o que as torna não rastreáveis, além de raras). Assim, o sistema Botucatu, com sua faciologia monótona e pouco diversificada, caracterizaria um sistema eólico seco.

O contraste faciológico entre os depósitos dos sistemas deposicionais eólicos Pirambóia (úmido costeiro) e Botucatu (seco) e a contemporaneidade entre a sedimentação no sistema eólico Pirambóia e no Mar Passa Dois (Permiano) e entre o sistema eólico Botucatu e os derrames Serra Geral (Jurássico a Cretácea) implica presença de um hiato deposicional da ordem de dezenas de milhões de anos entre estes dois sistemas eólicos. A superfície que separa os depósitos destes dois sistemas eólicos teria um caráter de discordância. $O$ final da sedimentação no sistema eólico Botucatu bem como a preservação dos seus depósitos estariam intimamente relacionados aos derrames 
Serra Geral. A espessa camada de rocha basáltica protegeu os arenitos eólicos da erosão pois serviu como uma camada protetora das formas de leito e provocou uma nova fase de subsidência durante a qual se depositaram os sedimentos da Bacia Bauru (Fernandes 1998). Com base no modelo genético integrado (associações e ambientes) aqui proposto, o sumário final de fácies pode ser apresentado conforme o Quadro 03.

\section{Quadro 03. Sumário de fácies sedimentares dos sistemas eólicos Pirambóia e Botucatu no Paraná}

\begin{tabular}{|c|c|c|c|}
\hline $\begin{array}{l}\text { CÓDIGO } \\
\text { DA FÁCIES }\end{array}$ & $\begin{array}{l}\text { LITOLOGIA E ESTRUTURA } \\
\text { SEDIMENTAR MAIS DIAGNOSTICA (E } \\
\text { OUTRAS ESTRUTURAS COMUNS) }\end{array}$ & $\begin{array}{l}\text { PROCESSOS } \\
\text { SEDIMENTARES }\end{array}$ & SISTEMA \\
\hline Acb & $\begin{array}{l}\text { Arenito com estratificação cruzada } \\
\text { acanalada de baixo ângulo }\left(<15^{\circ}\right) \text { e } \\
\text { microondulações } \\
\begin{array}{l}\text { subcríticas. } \\
\text { lavalgantes }\end{array}\end{array}$ & $\begin{array}{l}\text { Instalação de lençóis de areia e } \\
\text { dunas incipientes em contexto } \\
\text { costeiro, com influência ocasional } \\
\text { de correntes na zona intermarés. }\end{array}$ & Pirambóia \\
\hline Aca & $\begin{array}{l}\text { Arenito com estratificação cruzada de } \\
\text { alto ângulo }\left(<15^{\circ}\right) \text { (lentes de fluxo } \\
\text { granular; superficies de } 2^{\mathrm{a}} \text { e } 3^{\mathrm{a}} \text { ordem). }\end{array}$ & $\begin{array}{l}\text { Avanço de dunas barcanas em } \\
\text { sistema eólico úmido. }\end{array}$ & Pirambóia \\
\hline Acbl & $\begin{array}{l}\text { Arenito com estratificação cruzada de } \\
\text { baixo ângulo com lâminas pelíticas de } \\
\text { cores avermelhadas ou esverdeadas } \\
\text { (laminações cruzadas cavalgantes } \\
\text { subcríticas; convoluçōes suaves; } \\
\text { laminações heterolíticas incipientes; } \\
\text { flocos de lama encurvados). }\end{array}$ & $\begin{array}{l}\text { Inundação efêmera de planícies } \\
\text { interdunares em condiç̋es } \\
\text { deposicionais ou eodiagenéticas } \\
\text { oxidantes, altemando transporte } \\
\text { trativo em regime de fluxo inferior } \\
\text { e suspensão. }\end{array}$ & Pirambóia \\
\hline ACc & $\begin{array}{l}\text { Arenito conglomerático com depósitos } \\
\text { residuais de fenoplastos de lama } \\
\text { esverdeada subarredondados, } \\
\text { preenchendo paleocanais e estruturas } \\
\text { de corte (convoluçőes suaves; marcas } \\
\text { de sola; intraclastos com laminação } \\
\text { interna milimétrica). }\end{array}$ & 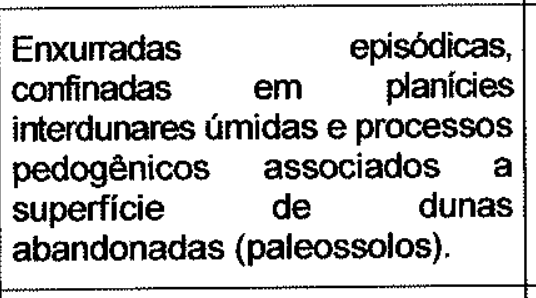 & Pirambóia \\
\hline $\mathrm{ACg}$ & $\begin{array}{l}\text { Arenito conglomerático com estratos } \\
\text { gradados (depósitos residuais de clastos } \\
\text { rudáceos de quartzo e quartzito } \\
\text { subangulosos a arredondados). }\end{array}$ & $\begin{array}{l}\text { Avanço de barras transversais } \\
\text { de rios entrelaçados. }\end{array}$ & Pirambóia \\
\hline Afca & $\begin{array}{l}\text { Arenito fino a muito fino com } \\
\text { estratificação cruzada de ângulo alto } \\
\text { (superfícies de truncamento onduladas; } \\
\text { séries métricas sigmóides; lentes de } \\
\text { fluxo granular). }\end{array}$ & $\begin{array}{l}\text { Avanço e cavalgamento de } \\
\text { dunas e draas em sistema } \\
\text { eólico seco. }\end{array}$ & Botucatu \\
\hline Afcd & $\begin{array}{l}\text { Arenito fino com cruzadas de alto } \\
\text { ángulo, deformadas (fragmentos } \\
\text { centimétricos de arenito microfalhados e } \\
\text { ligeiramente deslocados formando } \\
\text { pseudobrechas intraformacionais; } \\
\text { estratificaçöes convexas para cima, com } \\
\text { dobras suaves de comprimento métrico } \\
\text { (amplitude } \sim 25 \mathrm{~cm} \text { ), truncadas por } \\
\text { superficies de } 3^{\text {a }} \text { ordem). }\end{array}$ & $\begin{array}{l}\text { Escorregarnento de areia úmida } \\
\text { em face frontal de alto ángulo de } \\
\text { duna barcana: fragmentação de } \\
\text { blocos de areia úmida na parte } \\
\text { superior e compressão exercida } \\
\text { pelo escorregamento na parte } \\
\text { inferior. }\end{array}$ & Botucatu \\
\hline Afcb & $\begin{array}{l}\text { Arenito fino com cruzadas de ângulo } \\
\text { baixo (tubos de icnofósseis inclinados; } \\
\text { presença marcante de areia média). }\end{array}$ & $\begin{array}{l}\text { Deposição por suspensão e } \\
\text { chegada de dunas em planicies e } \\
\text { depressões interdunares secas. }\end{array}$ & Botucatu \\
\hline
\end{tabular}


depósitos deste sistemas não equivalem exatamente ao conceito litoestratigráfico de Formação Pirambóia definido por Soares (1975), daí o uso da designação sistema deposicional eólico úmido Pirambóia. Analogamente, as formaçöes Botucatu e Serra Geral podem ser relacionadas geneticamente a um mesmo sistema eólico seco.

Em relação a critérios de diferenciação entre os dois sistemas eólicos descritos no Quadro 05, cabe a seguinte ressalva: em nenhuma hipótese os critérios se aplicam de maneira isolada. Individualmente são insuficientes para a caracterização das unidades, mas, se considerados em conjunto, constituem um arcabouço coerente de cada sistema, tão mais seguro quanto maior for o número de informaçōes de campo.

\section{Quadro 04. Critérios de campo para distinção entre os depósitos dos sistemas deposicionais eólicos úmido (Pirambóia) e seco (Botucatu)}

\begin{tabular}{|c|c|}
\hline SISTEMA PIRAMBÓIA & SISTEMA BOTUCATU \\
\hline $\begin{array}{l}\text { Geomorfologia de pé-de-escarpa, com relevo } \\
\text { suavemente ondulado }\end{array}$ & $\begin{array}{l}\text { Geomorfologia de frente de escarpa, com } \\
\text { relevo ingreme }\end{array}$ \\
\hline $\begin{array}{l}\text { Padrão de alteração em formas arredondadas } \\
\text { (casco-de-tartaruga) }\end{array}$ & Padrão de alteração em juntas subverticais \\
\hline $\begin{array}{c}\text { Cor rósea, esbranquiçada ou esverdeada, às } \\
\text { vezes variegada }\end{array}$ & Cor avermelhada ou alaranjada, homogênea \\
\hline Heterogeneidade faciológica & Homogeneidade faciológica \\
\hline $\begin{array}{c}\text { Estratos espessos (da ordem de centímetros a } \\
\text { metros) mais ressaltados que laminações } \\
\text { milimétricas, em escala de afloramento }\end{array}$ & $\begin{array}{l}\text { Laminações milimétricas bem ressaltadas em } \\
\text { escala de afloramento }\end{array}$ \\
\hline $\begin{array}{l}\text { Lentes de fluxo granular com espessura } \\
\text { centimétrica, descontinuas }\end{array}$ & $\begin{array}{l}\text { Lentes de fluxo granular com espessura } \\
\text { milimétrica, contínuas }\end{array}$ \\
\hline $\begin{array}{l}\text { Séries de estratificações com espessura média } \\
\text { máxima de } 2 \mathrm{~m}\end{array}$ & $\begin{array}{r}\text { Séries de estratificações } \\
\text { máxima de }\end{array}$ \\
\hline $\begin{array}{c}\text { Presença freqüente de estratificações plano- } \\
\text { paralelas }\end{array}$ & Escassez de estratificações plano-paralelas \\
\hline $\begin{array}{c}\text { Geometria acanalada/festonada das } \\
\text { estratificaçóes, nítida }\end{array}$ & $\begin{array}{l}\text { Geometria acanalada/festonada das } \\
\text { estratificações pouco perceptível, exceto em } \\
\text { exposiçóes de espessura decamétrica }\end{array}$ \\
\hline $\begin{array}{l}\text { Presença freqüente de estratos pelíticos, } \\
\text { laminações heteroliticas, estruturas de } \\
\text { sobrecarga, estruturas de corte e preenchimento } \\
\text { e bioturbações, onde predominam os } \\
\text { icnogêneros sob forma de tubos. }\end{array}$ & $\begin{array}{l}\text { Presença freqüente de fenoplastos tabulares } \\
\text { de arenito nas estratificações cruzadas frontais } \\
\text { de alto ângulo. Presença de pegadas. }\end{array}$ \\
\hline $\begin{array}{l}\text { Presença de filmes, fenoplastos e flocos } \\
\text { encurvados de lama }\end{array}$ & Presença de feições irregulares poligonais \\
\hline $\begin{array}{l}\text { Presença de nível perturbado por dobras } \\
\text { métricas no topo }\end{array}$ & $\begin{array}{c}\text { Presença de dobras decimétricas a } \\
\text { centimétricas no topo (possíveis estruturas de } \\
\text { escorregamento) }\end{array}$ \\
\hline Presença de fácies areno-rudácea & $\begin{array}{l}\text { Ocorrência de granulos rara e muito } \\
\text { subordinada (menor que } 1 \% \text { ) }\end{array}$ \\
\hline $\begin{array}{l}\text { Distribuição granulométrica com predomínio de } \\
\text { moda nas frações areia média e fina }\end{array}$ & $\begin{array}{c}\text { Distribuição granulométrica com predomínio de } \\
\text { moda nas frações areia fina e muito fina }\end{array}$ \\
\hline $\begin{array}{c}\text { Cimentação aparente por material argilo- } \\
\text { ferruginoso }\end{array}$ & Freqüente cimentação silicosa \\
\hline $\begin{array}{l}\text { Superfícies de truncamento de } 3^{a} \text { ordem } \\
\text { espacadas em intervalos centimétrico a métrico }\end{array}$ & $\begin{array}{l}\text { Superfícies de truncamento de } 3^{\mathrm{a}} \text { ordem } \\
\text { espaçadas em intervalos métrico a decamétrico }\end{array}$ \\
\hline
\end{tabular}


É importante ressaltar ainda um critério adicional (não necessário, nem suficiente) para identificação do contato entre as duas unidades: a presença de nível centimétrico irregular de argila branca (caulinita) com seixos e grânulos associados. Uma interpretação plausivel para a presença deste nivel de argila caulinítica é a de percolação preferencial de fluidos da zona vadosa através da superfície de descontinuidade física existente no contato entre os depósitos das duas formações. 


\subsection{Fatores reguladores da dinâmica dos sistemas Pirambóia e Botucatu}

Admitida a premissa de que os sedimentos do Grupo Passa Dois foram depositados sob influência de processos de planície de maré, o sistema Pirambóia teria como fonte potencial de areia as zonas de infra e intermaré. A dificuldade encontrada até - momento é determinar como sedimentos arenosos submersos poderiam ser disponibilizados para o sistema eólico.

Segundo o princípio de Bruun (1962), variações de aporte geram desequilíbrio na zona costeira, face ao aumento da espessura da lâmina d'água, em resposta à elevação do nivel relativo do mar (NRM). Dessa forma, subida do NRM implicaria acreção do fundo marinho (depositado sob influência da menor espessura da lâmina d'água) na face litorânea. Admite-se que parte dos sedimentos colocados em desequilibrio na praia pela subida do NRM seria transportada pelo vento para formar o sistema deposicional eólico (Giannini \& Santos 1994).

A queda do NRM, provocando a exposição subaérea das zonas de inter e inframarés, retrabalhadas pelo vento à medida que o mar Passa Dois regredia, seria outra hipótese capaz de explicar o mecanismo supridor de areia para o sistema Pirambóia, com atuação de processos oriundos de tempestade, responsáveis pelo empilhamento de estoques de areia na zona de supramaré. Dessa forma, as tempestades poderiam ser comparadas a subidas locais do nível do mar. Um dado de campo que é favorável a esta hipótese seriam os depósitos atribuídos a atuação de tempestades das formações Terezina, Rio do Rasto e Corumbatai (Sawakuchi 2000; Giannini 2001).

A formação de depósitos eólicos requer, além de influxo de carga sedimentar (areia com granulação adequada ao transporte pelo vento), espaço de acomodação e de preservação, gerados possivelmente com a elevação do nível do mar, e por extensão, do nivel freático. Esta elevação seria responsável pela ampliação do potencial de preservação do sistema eólico costeiro, via aumento de espaço de acomodação. Por outro lado, o rebaixamento do NRM ou do nivel de base de erosão favoreceria a dissecação e a incisão fluvial, diminuindo o potencial de preservação do sistema eólico costeiro. Conclui-se portanto que, em depósitos eólicos, os processos atuantes na constituição dos depósitos dependem de vários fatores além da disponibilidade de areia. No cenário continental, onde não há influência costeira, o potencial de preservação é favorecido principalmente pela elevação do nível freático, ou como parece ter sido o caso do sistema Botucatu, por derrames extensivos de lavas de caráter fluidal. 


\subsection{Superfícies de truncamento}

Foram identificadas superfícies de truncamento de $3^{a}$ ordem espaçadas em intervalos decimétricos a métricos, associadas às fácies Aca e Acb, de sistema deposicional eólico úmido. Já no caso das fácies Afcad e Aecb, de sistema deposicional eólico seco, o intervalo entre as superfícies de $3^{a}$ ordem tem espaçamento maior, $2 \mathrm{~m} \mathrm{em}$ média. A diferença de espaçamento entre as superfícies de $3^{a}$ ordem pode ser o registro de migração de dunas barcanas incipientes ou de sucessivas modificações na direção dos paleoventos. Dunas incipientes são mais sensiveis a variações do regime eólico e uma alteração na dinâmica dos ventos permite a formação daquelas superficies.

Superficies de $2^{\mathrm{a}}$ ordem foram identificadas na região do Norte Velho paranaense, ponto IP.01, folha de Ipauçu, SP, em pedreira localizada no município de Ribeirão do Pinhal, PR, na frente da cuesta de arenito silicificado. Os azimutes de mergulho obtidos revelam rumos WNW. As superfícies são marcadas por microondulações de elevada razão comprimento/altura (20 em média), assimétricas de crista reta e flanco abrupto voltado para ENE (50 a 90 ). Truncam estratificações cruzadas acanaladas de grande porte (espessura superior a $5 \mathrm{~m}$ ). Aceita a premissa de que estas medidas expressem tendência geral do campo de dunas Botucatu, os draas migrariam rumo SSW em São Paulo, declinando, no Paraná rumo WNW. Cabe resaltar que Bigarella et al. (1970/71), com base em cerca de 3.000 medidas de frentes de séries de cruzadas, verificou nesta mesma região, alterações no padrão de dispersão dos paleoventos.

As supersuperfícies foram identificadas em caráter tentativo, com base na descrição de fácies e nas seçōes colunares (Anexo 11). A dificuldade de identificação deve-se ao fato de que o registro sedimentar não apresenta qualidade de exposições necessária para este fim, em contraste ao que ocorre, por exemplo, no Estado de São Paulo.

A primeira supersuperfície, $\mathbf{S} 1$, delimita 0 contato entre as fácies tipicamente subaquosas, supostamente fluviais, sobre fácies supostamente eólicas. Considera-se que esta superficie, localizada pelo menos a $10 \mathrm{~m}$ abaixo do contato entre as formações Pirambóia e Botucatu, tenha ao menos em parte, caráter diácrono e continuidade até o Estado de São Paulo.

Outra supersuperfície, denominada de S 2, estaria no contato entre arenitos da Formação Botucatu e o primeiro derrame de lava da Formação Serra Geral. Representaria o desfecho da deposição da Formação Botucatu. Consiste, por definição, 
em superfície discordante, com característica peculiar: tem forma ondulada, e refletiria ao menos em parte, a paleotopografia da época do primeiro pulso magmático. Em alguns locais, como na serra do Cadeado, PR, e na serra de Botucatu, SP, associa-se a material piroclástico ejetado (bombas e lapillis, Figura 29). A S 2 constitui uma das mais extensas superfícies interpretadas, encontrada em praticamente toda as seções levantadas. Dela poder-se-ia inferir outras supersuperfícies, como por exemplo, no contato entre o topo dos arenitos Serra Geral e a base do segundo pulso magmático, de caráter intertrapiano, face ao confinamento a dois derrames de rocha ígnea.

As supersuperfícies representariam a interrupção temporária de transporte eólico, com desenvolvimento de depósitos de interdunas aquáticas e de inundação. A S 1 representa talvez o pico de elevação do nível de base de erosão (NBE), responsável pelo recobrimento de dunas da Formação Pirambóia. O desenvolvimento de sistema fluvial poderia ser em resposta a variação do nível de base por mudanças climáticas ou a modificação da taxa de subsidência da bacia, possibilitando a instalação de um planície aluvial com sistema fluvial entrelaçado de deserto, oueds, e leques aluviais associados. Uma interpretação alternativa é que a intensificação da participação de água no final do sistema esteja relacionada à elevação do nível relativo do Mar Passa Dois, admitindo-se para isso certa proximidade deste mar, e que fosse ele o responsável pelas oscilações do NBE, garantindo, ao menos em parte, um influxo de sedimentos nas áreas interdunares. Admitindo-se como premissa a teoria de Kocurek \& Havholm (1993) sobre estratigrafia de seqüências continentais, a elevação do nível do relativo do mar aumentaria não apenas o aporte, mas também o potencial de preservação dos sedimentos.

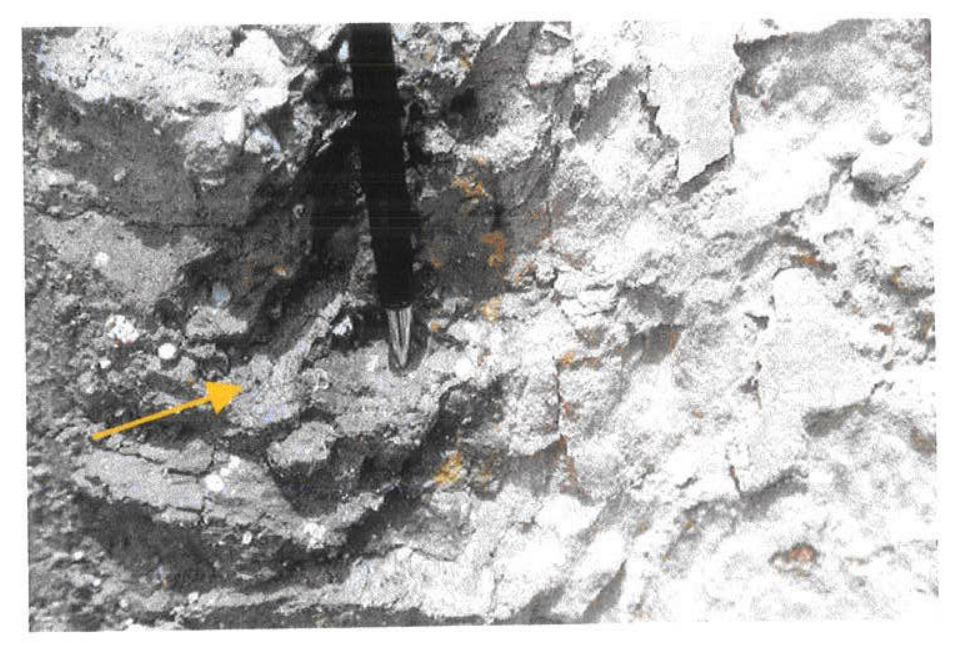

Figura 29 - Arenito fino a médio com fragmento de rocha ígnea, de coloração escura, interpretada como de origem piroclástica que teria recoberto dunas eólicas inconsolidadas do sistema Botucatu. Foto do ponto MS.03, serra do Cadeado, região centro-norte do Paraná. 


\subsection{Azimutes de mergulho de estratificações cruzadas}

Os resultados de azimute de mergulho de estratificaçöes cruzadas encontram-se representados sob a forma de diagramas circulares de distribuição de freqüências (Figuras $30,31,32,33$ e 34), agrupados segundo fatias representativas das metades superior e inferior dos dois sistemas eólicos (Pirambóia e Botucatu-Serra Geral), por região e tipo de fácies (de caráter eólico ou subaquoso). Os dados apresentados resultam da aplicação de filtro faciológico prévio às medidas, de modo a separar as atitudes de estratificações tomadas nas fácies $\mathrm{ACg}, \mathrm{ACc}$ e $\mathrm{Acbl}$ do sistema Pirambóia, reconhecidamente subaquosas, daquelas obtidas em depósitos eólicos, pertencentes às fácies Aca e Acb. Um segundo tipo de filtro foi aplicado com intuito de eliminar as atitudes com ângulo de mergulho menor ou igual a $10^{\circ}$.

Os azimutes de mergulho foram obtidos em medidas efetuadas em estratificações cruzadas acanaladas, geradas por formas de leito eólicas ou subaquosas de crista sinuosa. Admitiu-se como rumo de paleofluxo sedimentar o vetor médio das distribuições de freqüência obtidas.

A metade inferior do sistema Pirambóia (Quadro 05; Figura 30) apresenta, nas diferentes regiões estudadas, amplo intervalo modal, com vetores médios dos rumos de cruzadas exclusivamente eólicas nos quadrantes NE e NW, no Paraná, e SW no sul de São Paulo. A dispersão é particularmente bem marcada na base da unidade, logo acima da passagem com o Grupo Passa Dois, mesmo em escala de afloramento. A zona de convergência dos ventos voltados para o hemisfério Norte e Sul coincide com o alinhamento de Guapiara (entre as regiôes de Piraju, SP, e Jacarezinho, PR. Na região de Piraju, é importante também o rumo $E$, encontrado apenas em medidas de estratificações cruzadas de baixo ângulo $\left(<10^{\circ}\right)$, de caráter subaquoso. Já os depósitos interpretados como de dunas eólicas costeiras, com ângulo de mergulho igualmente inferior a $10^{\circ}$, apresentam-se paralelos ao rumo interpretado de migração das formas de leito fluviais (sW).

Quadro 05. Rumos de paleoventos interpretados para a metade inferior do sistema Pirambóia

\begin{tabular}{|c|c|c|}
\hline Localidade & Estado & $\begin{array}{c}\text { Rumo } \\
\text { (quadrante) } \\
\text { interpretado }\end{array}$ \\
\hline Piraju & $\mathrm{SP}$ & $\mathrm{SW}$ \\
\hline Jacarezinho & $\mathrm{PR}$ & $\mathrm{NW}$ \\
\hline Guarapuava & $\mathrm{PR}$ & $\mathrm{NE}$ \\
\hline
\end{tabular}


Os rumos de paleocorrentes e paleoventos interpretados para a metade superior do sistema Pirambóia, aproximados aos quatro quadrantes diagonais, são apresentados no Quadro 06 e na Figura 31. Dentre os rumos de paleoventos medidos em fácies eólicas, podem ser distintos dois grupamentos: um composto por ventos que sopravam para o hemisfério Norte (NE) e outro composto por ventos que sopravam para o hemisfério Sul (SW). O limite entre as zonas de ocorrência dos ventos com rumo Sul e Norte pode ter permanecido sobre o flanco sul do alinhamento de Guapiara (Jacarezinho, PR), onde se observam paleoventos para $W$.

Quadro 06 - Rumos de paleoventos interpretados para a metade superior do sistema Pirambóia

\begin{tabular}{|c|c|c|}
\hline Localidade & Estado & $\begin{array}{c}\text { Rumo } \\
\text { interpretado }\end{array}$ \\
\hline Piraju & SP & SW \\
\hline Jacarezinho & PR & W \\
\hline $\begin{array}{c}\text { União da } \\
\text { Vitória }\end{array}$ & PR & NE \\
\hline
\end{tabular}

Os quadrantes de paleocorrentes subaquosas interpretados para o sistema Pirambóia superior (Quadro 07; Figura 31) também podem ser subdivididos em dois grupos (para sul e para norte) de acordo com sua distribuição geográfica. Nesta fatia estratigráfica não foram encontradas evidências que comprovassem o desenvolvimento de fácies costeiras. Em contrapartida, há franco predomínio de fácies arenoconglomeráticas, interpretadas como de caráter fluvial, denominadas nesta Dissertação como $\mathrm{ACg}$ e ACc. As paleocorrentes fluviais deste intervalo estratigráfico no Paraná variam entre $W$ e SW. Observa-se variação significativa junto ao alinhamento de Guapiara, onde o rumo SW, em Jacarezinho, PR, contrasta com o NW, em Piraju, SP.

Quadro 07 - Paleocorrentes fluviais interpretadas para a metade superior do sistema Pirambóia

\begin{tabular}{|c|c|c|}
\hline Localidade & Estado & $\begin{array}{c}\text { Rumo } \\
\text { interpretado }\end{array}$ \\
\hline Piraju & SP & NW \\
\hline Jacarezinho & PR & SW \\
\hline Ivaiporã & PR & W \\
\hline Guarapuava & PR & SW \\
\hline $\begin{array}{c}\text { União da } \\
\text { Vitória }\end{array}$ & PR & SW \\
\hline
\end{tabular}


Supõe-se que a persistência do rumo SW nas paleocorrentes represente o paleodeclive da bacia durante o final da deposição Pirambóia, e que o rumo NW, na borda norte do alinhamento Guapiara, tenha alguma ligação com presença de barreira geográfica, a qual seria responsável pela alteração do fluxo fluvial na região.

$\mathrm{Na}$ metade inferior dos arenitos Botucatu, encontrou-se vetor médio rumo SW, exceto em Guarapuava (Quadro 08, Figura 32). Observa-se polimodalidade em Guarapuava e Piraju. Em direção ao topo da unidade, a tendência a polimodalidade se acentua (Figura 33), resultando em discrepância de vetores médios.

Quadro 08 - Rumos de paleoventos interpretados para a metade inferior do sistema Botucatu

\begin{tabular}{|c|c|c|}
\hline Localidade & Estado & $\begin{array}{c}\text { Rumo } \\
\text { (quadrante) } \\
\text { interpretado }\end{array}$ \\
\hline Piraju & SP & SSW \\
\hline Jacarezinho & PR & WSW \\
\hline Ivaiporã & PR & SW \\
\hline $\begin{array}{c}\text { Guarapuava } \\
\begin{array}{c}\text { União da } \\
\text { Vitória }\end{array}\end{array}$ PR & NE \\
\hline
\end{tabular}

Quadro 09 - Rumos de paleoventos interpretados para a metade superior do sistema Botucatu

\begin{tabular}{|c|c|c|}
\hline Localidade & Estado & $\begin{array}{c}\text { Rumo } \\
\text { (quadrante) } \\
\text { interpretado }\end{array}$ \\
\hline Piraju & SP & N \\
\hline Jacarezinho & PR & SW \\
\hline Ivaiporã & PR & NW \\
\hline Guarapuava & PR & ENE \\
\hline
\end{tabular}

Quadro 10 - Rumos de paleoventos interpretados para a metade superior do sistema Botucatu, pertencente à Formação Serra Geral

\begin{tabular}{|c|c|c|}
\hline Localidade & Estado & $\begin{array}{c}\text { Rumo } \\
\text { (quadrante) } \\
\text { interpretado }\end{array}$ \\
\hline Jacarezinho & PR & SW \\
\hline Ivaiporã & PR & NW \\
\hline Guarapuava & PR & S \\
\hline
\end{tabular}


O predomínio de distribuições unimodais e bimodais bipolares nos afloramentos estudados (Quadros 05 a 10, Figuras 30 a 34), associado à morfologia quase sempre acanalada das estratificações cruzadas, permitem interpretar o franco predomínio de dunas barcanas e suas variações morfológicas compostas (cadeias barcanóides e draas estrelados). Particularmente em relação ao sistema Botucatu, a presença constante com que se observa a diversidade de modas entre afloramentos de mesma área é sugestiva da existência de draas compostos, com movimento de dunas em mais de uma direção.

Giannini (2001) propôs que, em escala regional, a dispersão nos rumos de paleoventos pode estar associada à paleodinâmica atmosférica global e ao paleorelevo e/ou geometria da bacia e, sendo assim, não seria possível compreender a distribuição geográfica dos azimutes de paleoventos sem antes situar a deposição das areias eólicas no contexto paleogeográfico neopaleozóico-mesozóico da Bacia do Paraná. O mapa de isópacas dos arenitos Pirambóia e Botucatu (Araújo et al. 1995) indica a existência de uma calha alongada segundo NNE, com um depocentro principal a oeste do Arco do Rio Grande (nordeste da Argentina), e dois depocentros secundários, muito próximos entre si, no leste do Estado do Mato Grosso do Sul e no extremo oeste do Estado de São Paulo. A julgar pela disposição das linhas isópacas, o depocentro principal (sul) seria separado dos dois depocentros menores (norte) por um alto estrutural alongado NW, aproximadamente coincidente com o Arco de Ponta Grossa.

Aquele mesmo autor, admitindo como premissa a existência da geometria em calha de direção NNE já no Permiano, concluiu que um dos modelos aceito para o Mar Passa Dois seria a de um golfo alongado segundo o eixo maior da bacia, conectado a mar aberto pelo sul. O confinamento deste golfo seria dado a oeste pelo Arco de Assunción, a nordeste, pelo Arco da Canastra, e possivelmente a leste, pelo arco, ainda incipiente, que no final do Mesozóico daria lugar ao Oceano Atlântico. Para ele, no final do Permiano, o extenso perímetro costeiro deste golfo estaria ocupado por uma planície de maré mista, que se reflete nas associações de fácies das formações Serrinha e Terezina.

De acordo com o modelo de acúmulo e erosão de depósitos eólicos (Kocurek \& Havholm 1993), o lençol freático e a existência de espaço de acomodação são fatores de suma importância na preservação de sistemas eólicos. A espessura preservada destes depósitos guarda relação estreita e direta com a proximidade entre superficie deposicional e lençol freático. Como resultado disso, depósitos eólicos mais próximos à costa têm mais chances de se preservar, seja pelo maior espaço de acomodação, seja pelo fato de a elevação do nivel freático em resposta à subida do nível relativo do mar (NRM) ser mais rápida na costa de que no interior do continente. Desse modo, a localização do 
depocentro principal dos arenitos eólicos da Bacia do Paraná poderia refletir diretamente a posição do centro da bacia e, por paradoxal que pareça, os sedimentos eólicos, tipicamente continentais, preservariam-se melhor nas áreas em que o lençol freático estava mais elevado (Giannini 2001).

Para Sawakuchi (2000) e Giannini (2001), a geometria transicional do contato inferior dos arenitos eólicos do sistema Pirambóia com os depósitos de maré do Grupo Passa Dois indica a proximidade deste sistema com a paleocosta Passa Dois. Esta interpretação admite a influência de ventos costeiros na distribuição dos azimutes da unidade, pelo menos na sua parte basal, considerando as seguintes premissas: que o mar regredia para sul, que a fonte de areias residia nas fácies de inframaré da Formação Serrinha, ou nas areias de frente deltaica da Formação Rio do Rasto (tipicamente representados apenas nos estados do Sul do país), e que ventos costeiros deveriam soprar para Norte. Nesse modelo, admite-se influência de ventos costeiros apenas nos estágios e regiōes de sedimentação eólica com registro de azimutes de paleoventos vindos de sul. $O$ exame da distribuição geográfica de azimutes nos arenitos Pirambóia em São Paulo (Sawakuchi 2000; Giannini 2001) permite observar que os paleoventos de sul restringem-se coincidentemente ao Estado do Paraná, o que fortalece a hipótese de influência de ventos costeiros no início da sedimentação Pirambóia, pelo menos nessa região. Admitida esta hipótese, o fato de o rumo atribuído aos paleoventos costeiros dispersar-se para SSW na metade superior da unidade, na parte norte do Paraná e sul de São Paulo (regiões de Jacarezinho e Piraju respectivamente), é explicado pelo afastamento da linha de costa, ainda no contexto regressivo do Mar Passa Dois, com conseqüente perda de competência dos ventos onshore.

A existência de paleoventos dirigidos para norte no Paraná e para sul e oeste em São Paulo (Sawakuchi 2000; Giannini 2001) permite interpretar a existência simultânea de dois influxos de areia eólica no sistema Pirambóia, um costeiro e outro continental. O efluxo responsável pela deposição das areias eólicas no Paraná estaria ligado à distância da paleolinha de costa $e$, conseqüentemente, à evolução do comportamento do NRM. O influxo continental deveria provir de duas áreas-fonte potenciais: uma a sudoeste, conforme sugerido pelo caminhamento preferencial das dunas eólicas basais do Pirambóia (para N), e outra de norte com dispersão rumo SSW, representativa de rios entrelaçados (fácies $\mathrm{ACg}$ e $\mathrm{ACc}$ ) formados possivelmente no final da sedimentação Pirambóia. A respeito do influxo continental, entretanto, pelo menos quatro questões não parecem suficientemente esclarecidas apenas com base neste modelo (Giannini 2001): 
1. Que condições geológicas garantiram o efluxo das areias eólicas trazidas de NE?

2. Se o influxo de areias eólicas é de NE, como se explicam os paleoventos para NW e o rumo de deslocamento de draas para $E$, inferidos para a região norte paulista?

3. Se os rios entrelaçados corriam persistentemente para SW, distais de um sistema de leques aluviais a NE, como se explica que as fácies grossas a eles associadas ocorram tão bem ou até melhor representadas no sul do Paraná de que no Estado de São Paulo?

4. Dada a coincidência do alto estrutural entre os depocentros com o Arco de Ponta Grossa e a existência de influxo costeiro de um lado e continental de outro, como se materializou na paleogeografia a separação entre estes dois depocentros e seus influxos?

De acordo com Giannini (2001), estas quatro questões convergem para a reconstituição de um cenário paleogeográfico algo mais complexo de que uma simples calha NNE, inclinada para SW. O autor evoca assim a existência de acidentes topográficos menores dentro desta calha, contribuindo para a compartimentação do influxo-efluxo eólico e garantindo o fornecimento de sedimentos, inclusive sedimentos rudáceos. A hipótese mais simples seria aceitar a existência de altos alongados na direção do Arco de Ponta Grossa, cujo soerguimento teria se acentuado no decorrer da sedimentação, como reflexo da crescente intumescência pré-derrame, em contexto de prenúncio de rift ou admitir que dunas imensas poderiam exercer um controle local de dispersão de paleoventos (Giannini et al. 1999b, 2000; Sawakuchi 2000). O certo é que o primeiro modelo explica o aparecimento de fácies conglomeráticas no final do sistema deposicional Pirambóia. Conta a seu favor também o fato de que a principal zona de convergência e/ou desvio de efluxos coincida, durante toda a sedimentação Pirambóia, com o flanco sul do Arco de Ponta Grossa (Figuras 30 e 31).

Outras hipóteses podem ser evocadas para explicar as mudanças de paleoventos entre diferentes regiões e intervalos da unidade Pirambóia, sem excluir necessariamente o modelo dos arcos (Giannini et al. 1999b, 2000: Sawakuchi 2000; Giannini 2001). Dentre estas hipóteses, destacam-se 1. alterações da dinâmica de massas de ar, impostas por mudanças tectônicas e paleoclimáticas globais; 2. caráter erosivo do topo das fácies eólicas do Pirambóia, criando uma superfície diácrona. Neste caso, as fácies de arenitos grossos $(\mathrm{ACg}$ e $\mathrm{ACC}$ ) estariam demarcando parcialmente a suposta superfície erosiva. 
Entretanto, a hipótese dos arcos parece mais convincente para a maior parte das questões, sem deixar de considerar o provável contexto geológico da bacia na época da sedimentação.

Em relação ao sistema Botucatu, a parte inferior da unidade teria sido depositada sob predomínio de paleoventos entre os quadrantes SW e SE. Estes dois azimutes coincidem com modas importantes no sistema Pirambóia, especialmente a norte do Arco de Ponta Grossa. Tal coincidência permite interpretar a manutenção dos fatores que determinaram os paleoventos para sul, quais sejam o confinamento dos ventos determinado pela morfologia alongada da bacia sedimentar e zona de influxo de areia eólica a nordeste. $O$ fato de o rumo SW prevalecer também nos afloramentos do Estado de São Paulo (Sawakuchi 2000) é um indício de que as barreiras representadas pelos arcos de direção NW já não mais se encontravam efetivas. Em direção ao final da sedimentação, determinado pelos derrames vulcânicos, o regime de paleoventos teria se tornado complexo, com grandes variações em pequenas distâncias. De acordo com Havholm \& Kocurek (1994), manifestaçōes vulcânicas podem alterar drasticamente os padrões de influxo eólico, uma vez que reduzem a área com areia exposta e disponível para o retrabalhamento eólico. Desse modo, a indefinição nos padrões de azimute na registro final (superior) do sistema Botucatu pode ter sido determinada por sua contemporaneidade com os primeiros derrames do magmatismo Serra Geral (Giannini 2001). No norte do Paraná, uma das modas, voltada para leste, caracterizaria inclusive a existência de ventos reversos, hipótese reforçada pelo rumo de caminhamento inferido de microondulações na região de Ribeirão Claro, PR, contra o mergulho das grandes estratificações cruzadas. 


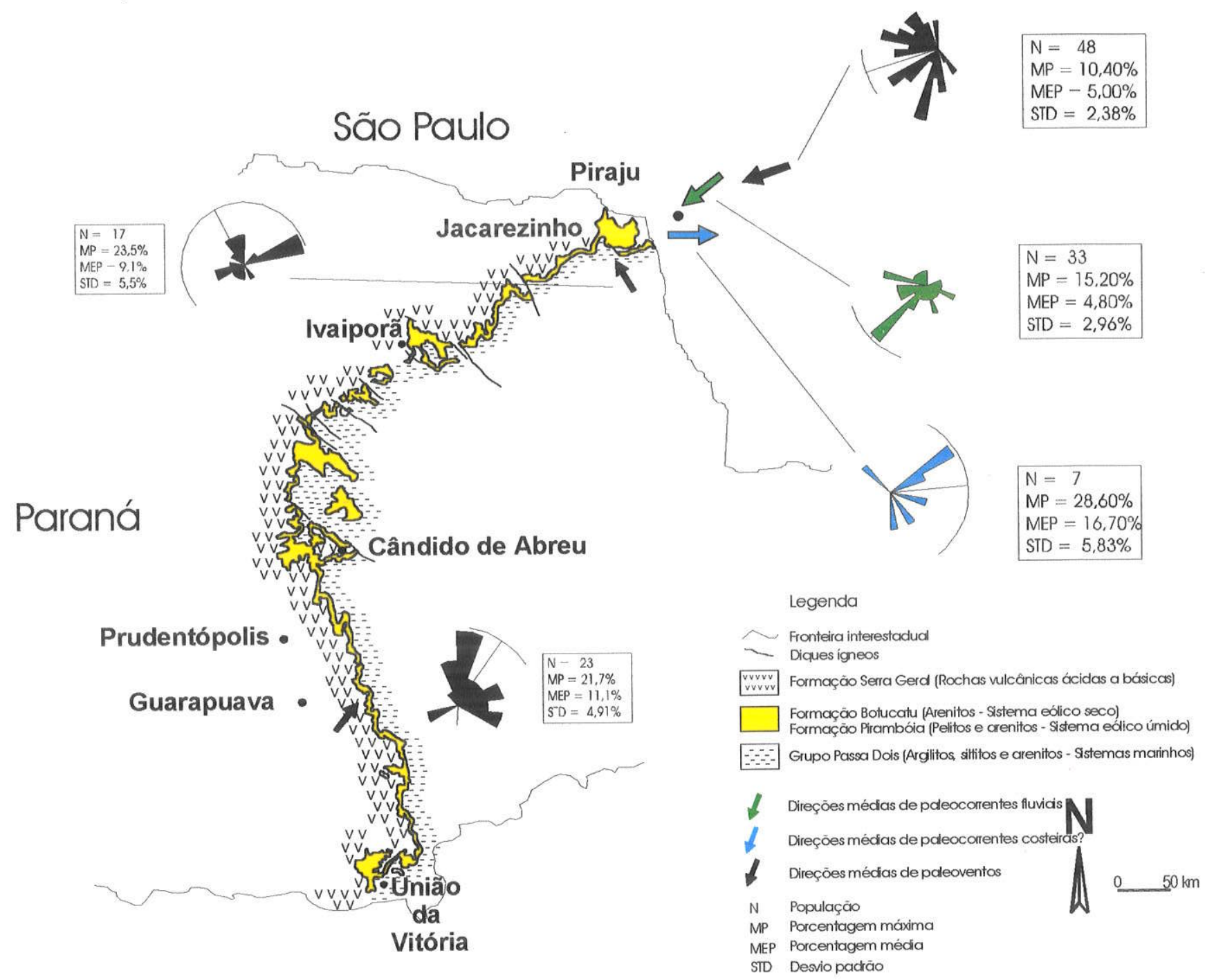

Figura 30 - Área de afloramento das formações Pirambóia e Botucatu no Estado do Paraná, com diagramas em rosa e direções de paleoventos e de paleocorrentes subaquosas interpretadas para a porção inferior do sistema eólico Pirambóia, lançados em mapa geológico modificado de Mineropar (1986). Ângulos de mergulho maior ou igual a $10^{\circ}$. 


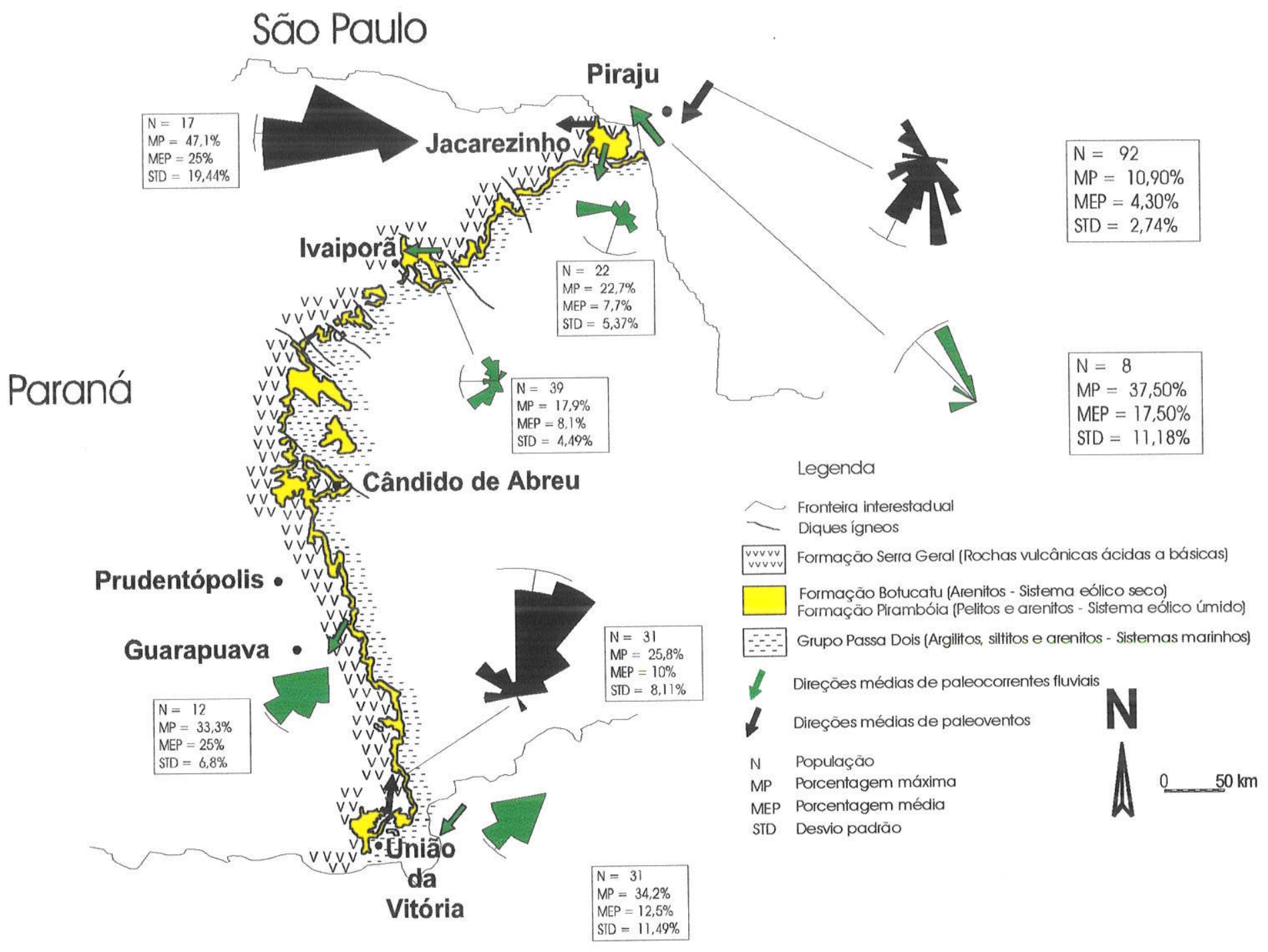

Figura 31 - Área de afloramento das formações Pirambóia e Botucatu no Estado do Paraná, com diagramas em rosa e direções de paleoventos e de paleocorrentes subaquosas interpretadas para a porção superior do sistema eólico Pirambóia, lançados em mapa geológico modificado de Mineropar (1986). Ângulos de mergulho maior ou igual a $10^{\circ}$. 


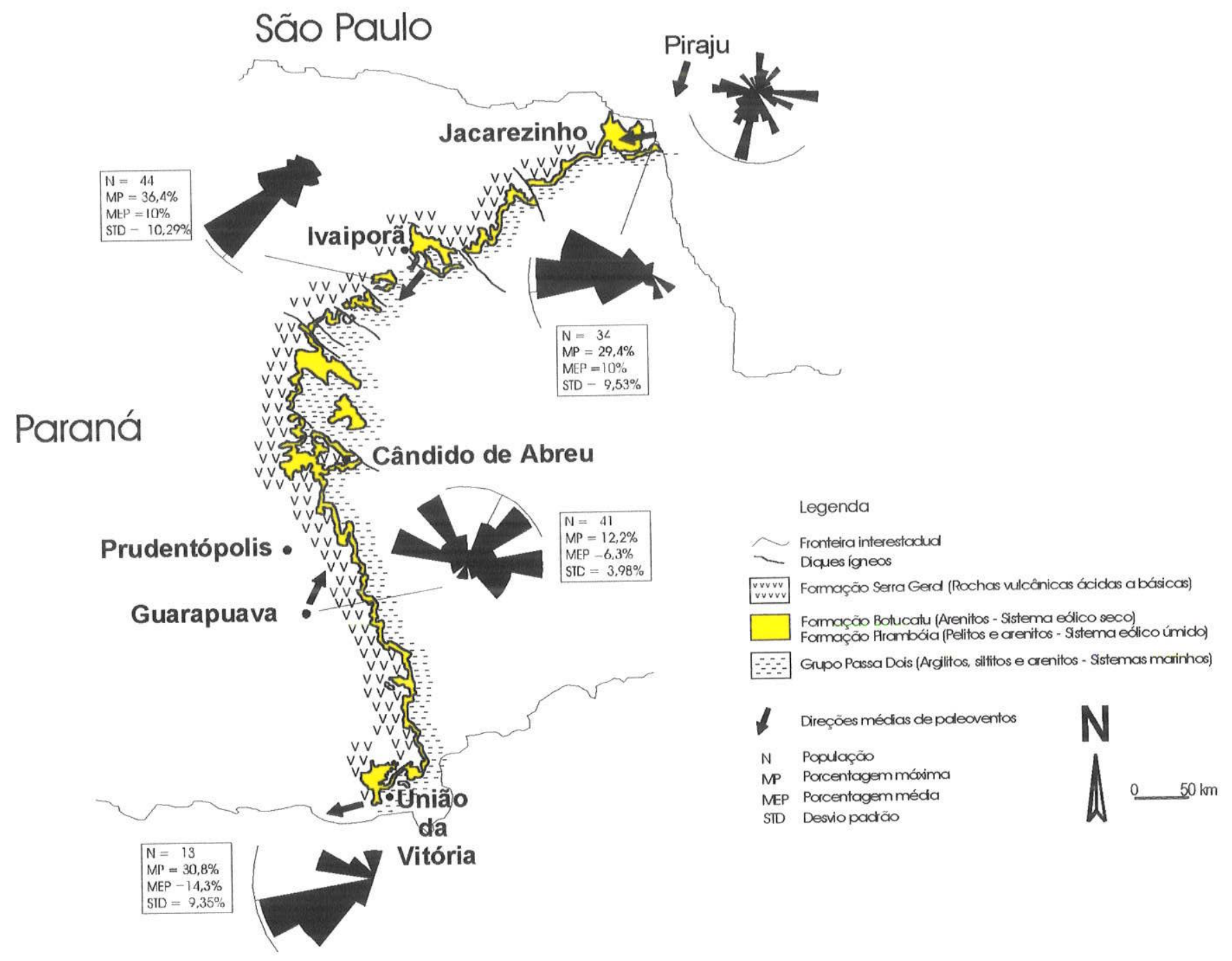

Figura 32 - Área de afloramento das formações Pirambóia e Botucatu no Estado do Paraná, com diagramas em rosa e direções de paleoventos interpretadas para a porção inferior do sistema eólico Botucatu, lançados em mapa geológico modificado de Mineropar (1986). Ângulos de mergulho maior ou igual a $10^{\circ}$. 


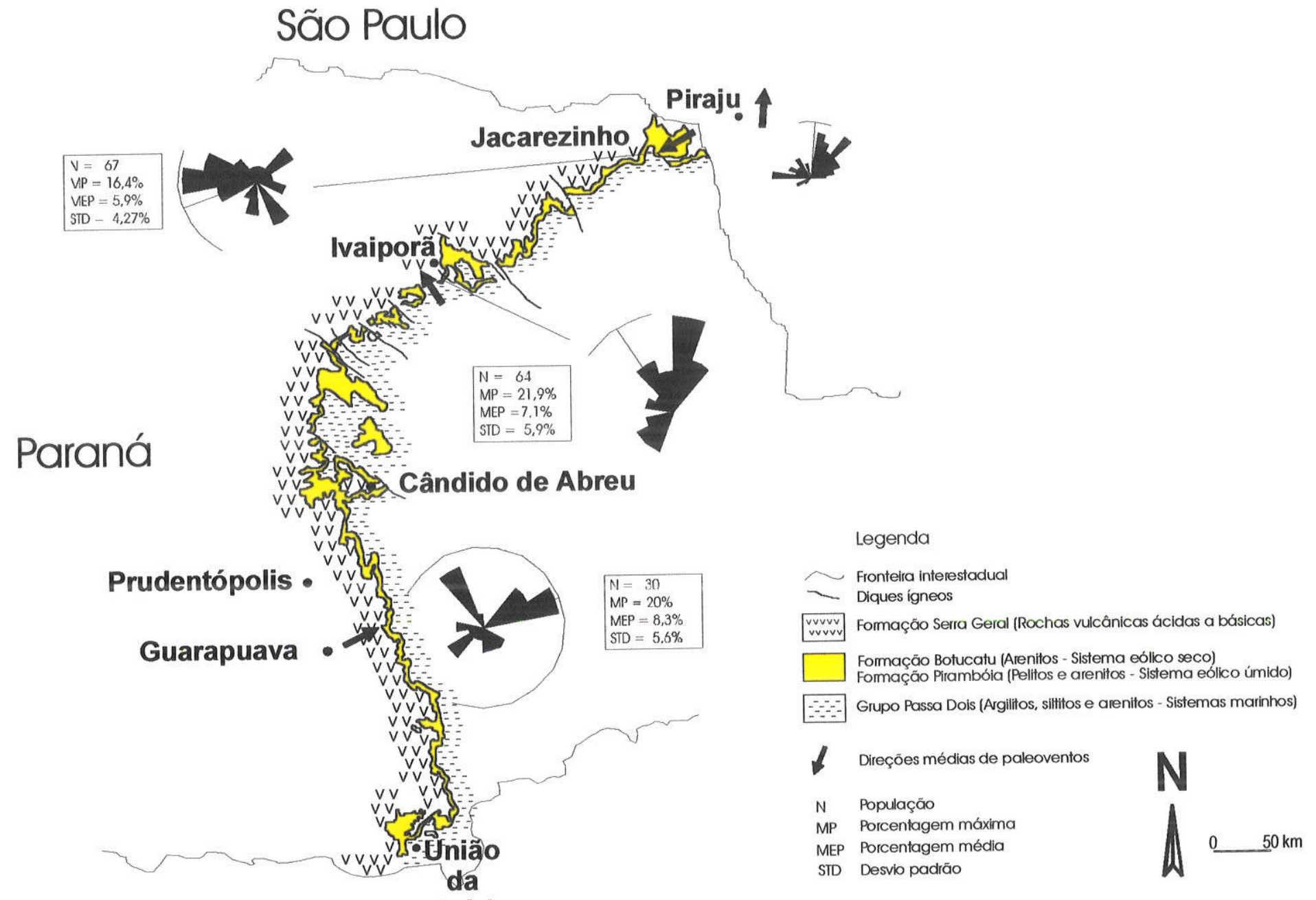

Vitória

Figura 33 - Área de afloramento das formações Pirambóia e Botucatu no Estado do Paraná, com diagramas em rosa e direções de paleoventos interpretadas para a porção superior do sistema eólico Botucatu, lançados em mapa geológico modificado de Mineropar (1986). Ângulos de mergulho maior ou igual a $10^{\circ}$. 


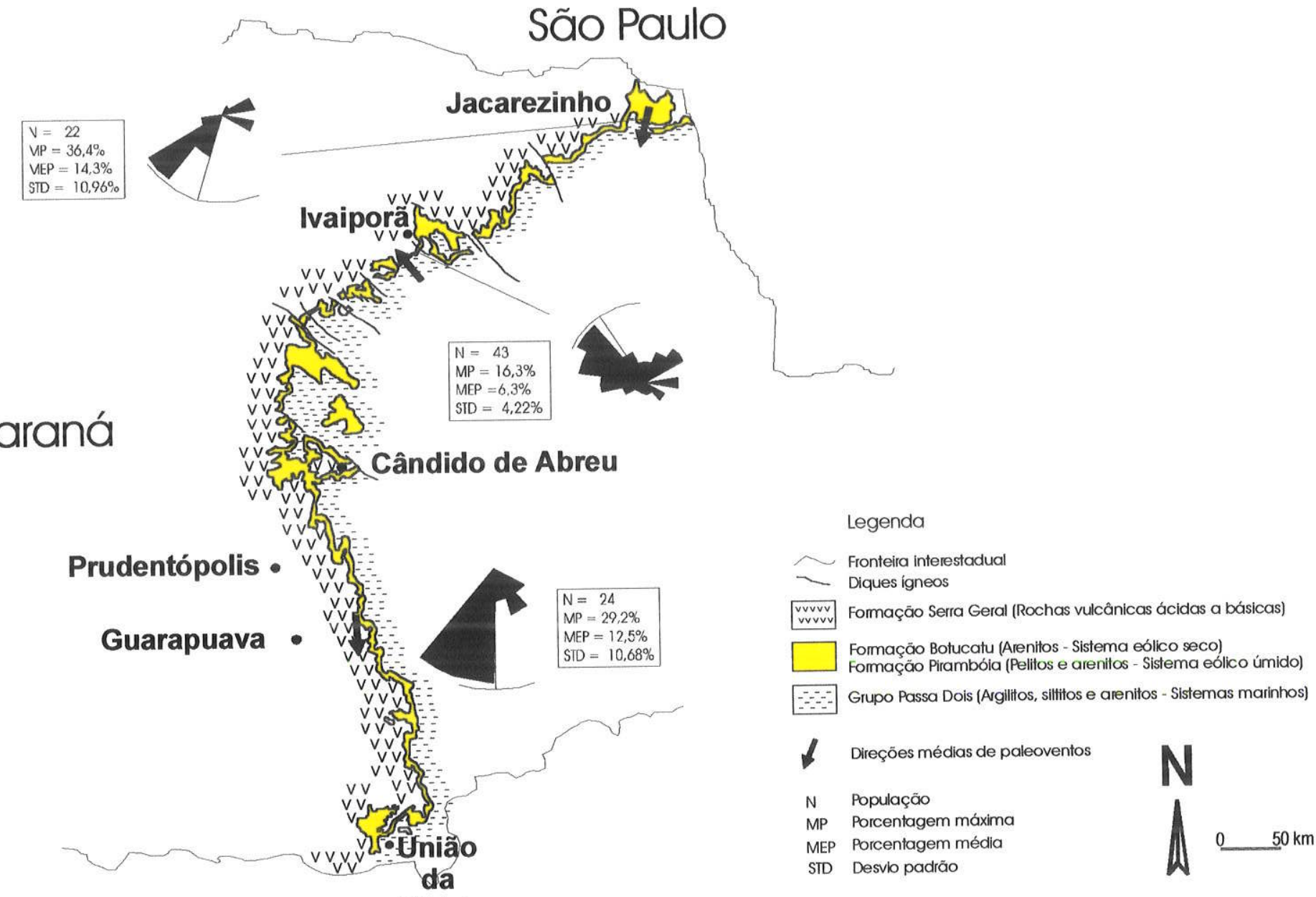

Vitória

Figura 34 - Área de afloramento das formações Pirambóia e Botucatu no Estado do Paraná, com diagramas em rosa e direções de paleoventos interpretadas para o sistema eólico seco Botucatu (arenitos intertrapp), lançados em mapa geológico modificado de Mineropar (1986). Ângulos de mergulho maior ou igual a $10^{\circ}$. 


\section{8. Ângulos de mergulho de estratificações cruzadas}

Para efeito de comparação visual apresentam-se os principais parâmetros estatísticos da distribuição de freqüências de ângulos de mergulho de estratificações cruzadas dos sistemas eólicos Pirambóia e Botucatu no Paraná, através da confecção de gráficos de barras (Figuras 35 e 36).

Os ângulos de mergulho demonstram diferença sutil quanto às médias parciais calculadas por região e na mesma fatia estratigráfica nas duas formações.

$\mathrm{Na}$ Formação Botucatu (Tabela 03), os parâmetros estatísticos indicam homogeneidade de ângulos de mergulho, com diferença sutil no desvio padrão se comparado ao desvio padrão do sistema Pirambóia (Figuras 35 e 36). Este parâmetro exibe tendência descendente em direção ao topo do sistema Botucatu, o que pode ser atribuído à homogeneidade crescente da distribuição de freqüências dos ângulos de mergulho (Figura 35). Esta homogeneidade apresentada pelo cálculo de desvio padrão poderia refletir a menor diversidade de mergulhos dentro do sistema eólico Botucatu, talvez em resposta à maior monotonia faciológica.

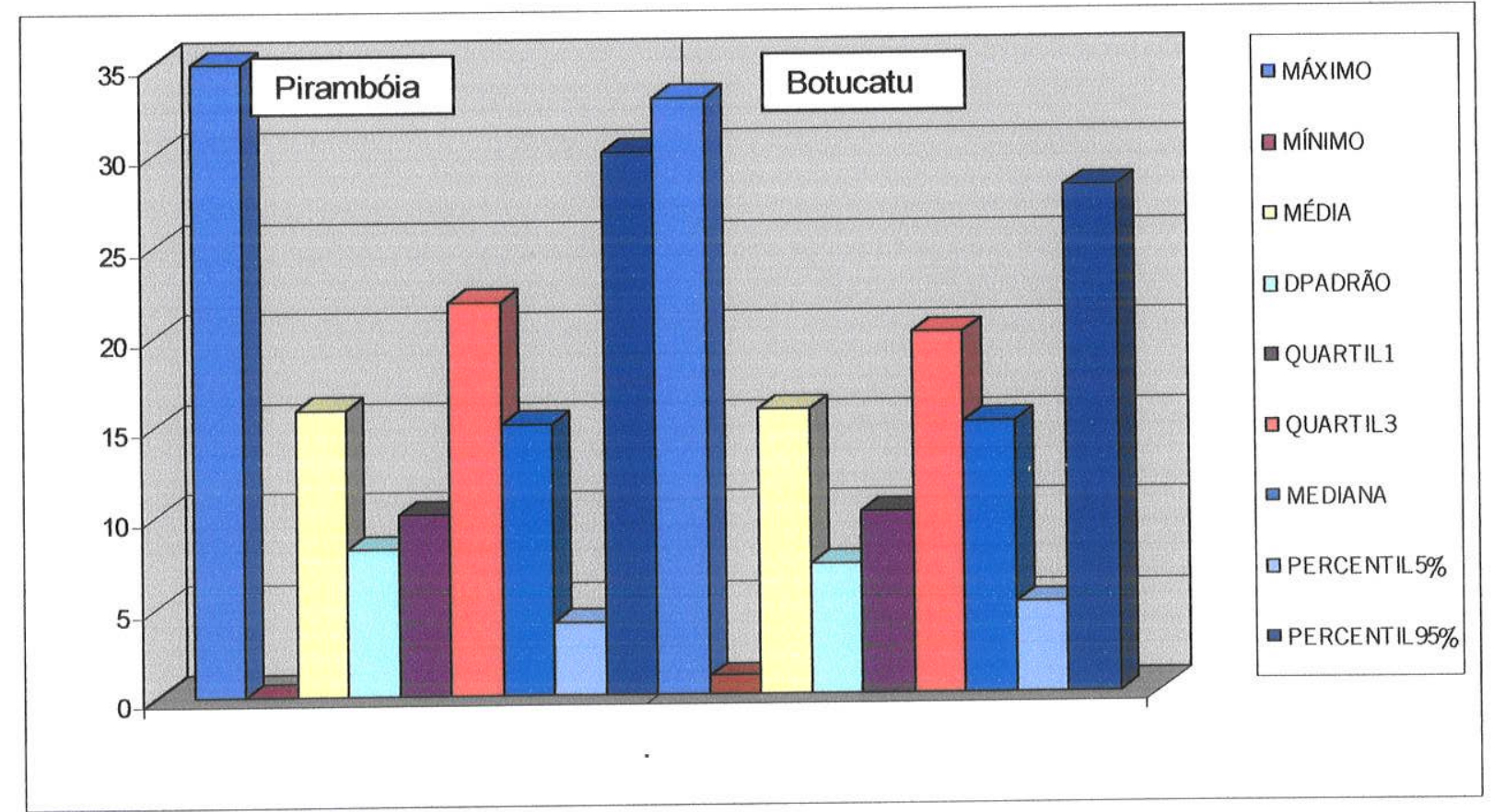

Figura 35 - Parâmetros estatísticos construídos a partir das medidas de ângulos de mergulho de estratificações cruzadas dos sistemas eólicos Pirambóia e Botucatu no Estado do Paraná. As setas ressaltam a diferença de desvio padrão entre as formações. 


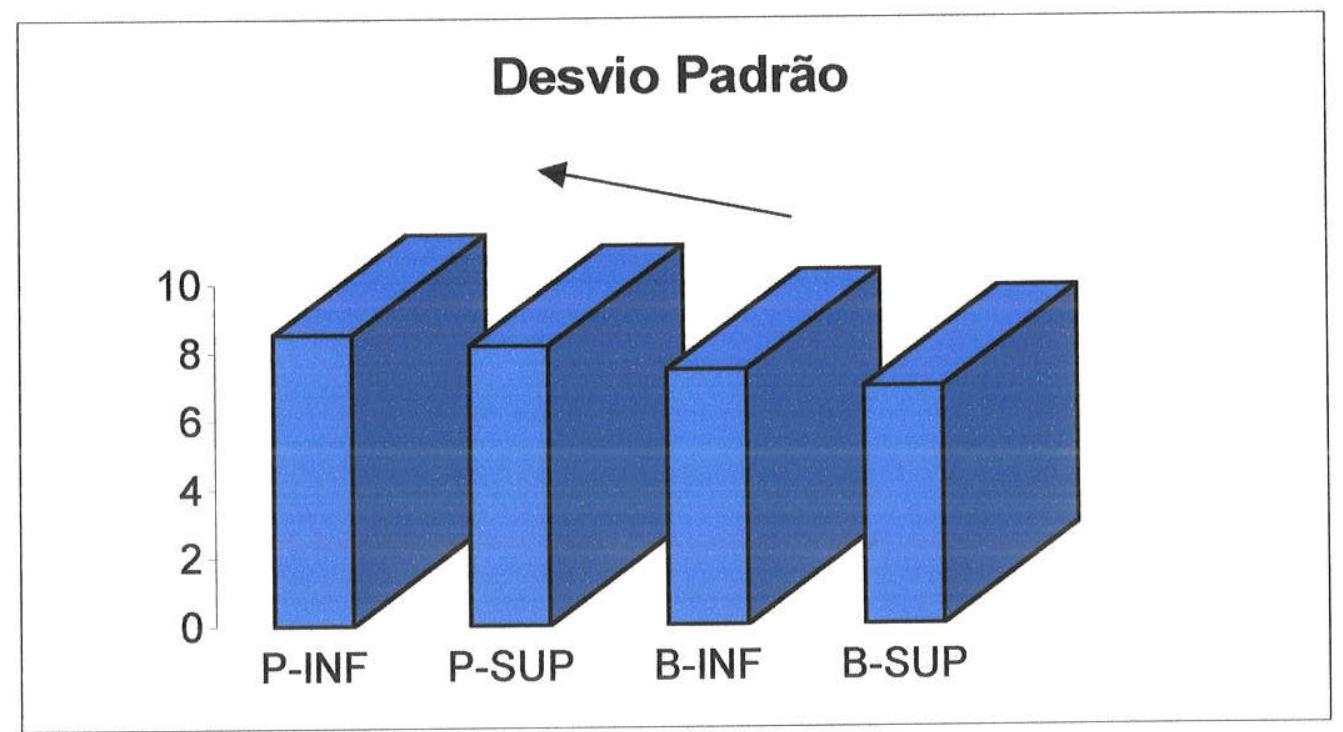

Figura 36 - Valores do desvio padrão obtidos a partir das medidas de azimutes de mergulho de estratificações cruzadas das fácies Aca, ACc, ACg e Afca dos sistemas eólicos, Pirambóia (P) e Botucatu (B), no Paraná, divididas em porções inferior (INF) e superior (SUP). Para a confecção do gráfico adotou-se um filtro, sendo considerados valores com ângulo de mergulho superior a $5^{\circ}$. 
Tabela 02. Parâmetros de distribuição de freqüências de ângulos de mergulho de estratificações cruzadas do sistema Pirambóia no Paraná.

\begin{tabular}{|c|c|c|c|c|c|c|c|c|c|c|c|}
\hline \multirow{2}{*}{$\begin{array}{l}\text { PARÂMETROS } \\
\text { ESTATÍSTICOS }\end{array}$} & \multicolumn{5}{|c|}{ PIRAMBÓIA INFERIOR } & \multicolumn{5}{|c|}{ PIRAMBOIA SUPERIOR } & \multirow{2}{*}{$\begin{array}{l}\text { PIRAMBÓIA } \\
\text { TOTAL }\end{array}$} \\
\hline & SUL & $\begin{array}{c}\text { CENTRO- } \\
\text { SUL }\end{array}$ & \begin{tabular}{|c|} 
CENTRO- \\
NORTE
\end{tabular} & NORTE & TOTAL & SUL & $\begin{array}{c}\text { CENTRO- } \\
\text { SUL } \\
\end{array}$ & $\begin{array}{c}\text { CENTRO- } \\
\text { NORTE } \\
\end{array}$ & NORTE & TOTAL & \\
\hline MÁXIMO & 28 & - & 20 & 25 & 32 & 30 & 30 & 8 & 35 & 35 & 35 \\
\hline MiNIMO & 8 & - & 7 & 2 & 2 & 0 & 4 & 4 & 3 & 0 & 0 \\
\hline MÉDIA & 18,13 & - & 15,00 & 12,41 & 14,78 & 11,98 & 14,45 & 15,81 & 19,72 & 15,98 & 15,87 \\
\hline DPADRĀO & 10,84 & - & 3,54 & 7,13 & 8,53 & 7,23 & 6,66 & 6,49 & 9,39 & 8,18 & 8,13 \\
\hline QUARTIL1 & 6,00 & - & 14,75 & 6,00 & 7,00 & 5,00 & 9,50 & 10,00 & 12,00 & 10,00 & 10,00 \\
\hline QUARTIL3 & 27,50 & - & 16,50 & 19,00 & 20,00 & 16,25 & 19,00 & 20,00 & 28,00 & 21,75 & 21,75 \\
\hline MEDIANA & 22,00 & - & 15,00 & 12,00 & 15,00 & 12,00 & 15,00 & 16,00 & 20,00 & 15,00 & 15,00 \\
\hline PERCENTIL5\% & 3,70 & - & 9,45 & 2,05 & 3,00 & 2,00 & 5,00 & 4,00 & 4,65 & 4,00 & 4,00 \\
\hline PERCENTIL95\% & 30,60 & - & 19,30 & 23,85 & 28,00 & 26,95 & 25,40 & 26,60 & 32,35 & 30,00 & 30,00 \\
\hline POPULAÇÃO & 15 & - & 8 & 22 & 45 & 48 & 47 & 69 & 74 & 238 & 306 \\
\hline
\end{tabular}

Tabela 03. Parâmetros de distribuição de freqüências de ângulos de mergulho de estratificações cruzadas do sistema Botucatu, no Paraná.

\begin{tabular}{|c|c|c|c|c|c|c|c|c|c|c|c|}
\hline \multirow{2}{*}{$\begin{array}{l}\text { PARÂMETROS } \\
\text { ESTATÍSTICOS }\end{array}$} & \multicolumn{5}{|c|}{ BOTUCATUINFERIOR } & \multicolumn{5}{|c|}{ BOTUCATU SUPERIOR } & \multirow{2}{*}{$\begin{array}{l}\text { BOTUCATU } \\
\text { TOTAL }\end{array}$} \\
\hline & SUL & $\begin{array}{c}\text { CENTRO- } \\
\text { SUL }\end{array}$ & $\begin{array}{c}\text { CENTRO- } \\
\text { NORTE }\end{array}$ & NORTE & TOTAL & SUL & $\begin{array}{c}\text { CENTRO- } \\
\text { SUL }\end{array}$ & $\begin{array}{c}\text { CENTRO- } \\
\text { NORTE }\end{array}$ & NORTE & TOTAL & \\
\hline MÁXIMO & 23 & 30 & 25 & - & 30 & - & 31 & 33 & 26 & 33 & 33 \\
\hline MINIMO & 1 & 2 & 5 & - & 1 & - & 3 & 5 & 3 & 3 & 1 \\
\hline MÉDIA & 9,76 & 18,41 & 14,94 & - & 15,09 & - & 17,31 & 16,11 & 13,95 & 16,09 & 15,73 \\
\hline DPADRÃO & 6,44 & 8,11 & 5,18 & - & 7,47 & - & 7,50 & 6,47 & 6,90 & 6,25 & 7,15 \\
\hline QUARTIL1 & 4,00 & 12,00 & 11,00 & - & 10,00 & - & 11,75 & 12,00 & 8,75 & 10,00 & 10,00 \\
\hline QUARTIL3 & 14,00 & 26,00 & 19,00 & - & 20,00 & - & 23,25 & 20,00 & 20,00 & 20,00 & 20,00 \\
\hline MEDIANA & 8,00 & 20,00 & 14,00 & - & 14,50 & - & 17,50 & 15,00 & 13,50 & 15,00 & 15,00 \\
\hline PERCENTLL5\% & 3,00 & 5,40 & 7,00 & - & 4,00 & - & 5,35 & 6,00 & 4,00 & 5,00 & 5,00 \\
\hline PERCENTIL95\% & 21,20 & 30,00 & 24,00 & - & 28,00 & - & 29,65 & 28,00 & 25,05 & 28,00 & 28,00 \\
\hline POPULAÇÃO & 29 & 49 & 50 & - & 128 & - & 68 & 123 & 40 & 231 & 359 \\
\hline
\end{tabular}




\subsection{Granulometria}

Os resultados de ensaios granulométricos referentes às amostras friáveis encontram-se apresentados sob forma de gráficos de barras, construídos a partir de dados específicos da fração areia (Figuras 37 a 58) e da fração total (Figuras 55 a 58) para cada fatia estratigráfica estudada.

O gráfico da razão fino/grosso apresenta maiores valores de máximo e de amplitude no sistema Pirambóia superior (Figura 37). A variação no valor médio da razão fino/grosso (Figura 38) evidencia a tendência para valores maiores no Pirambóia inferior. Este resultado caracteriza a presença predominante de termos finos nas fácies presentes nas porçőes basais deste sistema (Acbl, principalmente, e Acb).

Para as frações areia muito grossa e areia grossa (Figuras 39 a 42), os gráficos de amplitude e de média apresentam entre si uma relativa coincidência sendo que os maiores valores estão no sistema Pirambóia superior e, secundariamente, no Botucatu inferior. No gráfico de amplitude da fração areia média (Figura 43), os valores permanecem maiores no Pirambóia superior; no entanto, há um aumento significativo no valor máximo e na amplitude do Botucatu superior. No gráfico de proporção média da fração areia média (Figura 44), observa-se tendência para decréscimo contínuo estratigrafia acima, da Formação Pirambóia superior para os arenitos intertrapp.

$\mathrm{Na}$ fração areia fina (Figuras 45 e 46 ) inverte-se esta tendência, com padrão crescente do Pirambóia inferior ao Botucatu superior. Verifica-se que a maior amplitude está na porção superior do Pirambóia e que há pouca diferença de amplitude entre as porções do Botucatu (Figura 45).

No gráfico de areia muito fina (Figuras 47 e 48), observa-se que os valores mais altos de máximo, amplitude e média encontram-se na fatia inferior do Pirambóia.

Para a fração argila (Figuras 49 e 50), os gráficos de amplitude e média apresentam coincidência quanto à menor amplitude e ao menor valor de máximo e de média no sistema Pirambóia superior. Nota-se que os maiores valores de máximo e média ocorrem no sistema Pirambóia inferior, e os menores valores na metade superior deste mesmo sistema, com tendência decrescente em direção ao arenito intertrapp.

Os maiores valores máximos e de amplitude, para os parâmetros diâmetro médio e desvio padrão obtidos das distribuições de freqüências da fração areia, encontram-se no Pirambóia superior (Figuras 51 e 52). Já as maiores amplitudes dos parâmetros assimetria e curtose encontram-se no Botucatu superior (Figuras 53 e 54), seguido pelo 
Pirambóia superior. Os gráficos de parâmetros estatísticos da fração total (Figuras 55 a 58) apresentam maiores valores de amplitude no Pirambóia superior.

O ensaio granulométrico permitiu caracterizar a existência da fácies areno-rudácea, atribuída à parte superior do Pirambóia. Permitiu caracterizar a tendência crescente de maturidade textural em direção ao topo do Botucatu (incluindo intertrapp) e a presença marcante de argila na Pirambóia inferior. $O$ aumento de maturidade, acompanhado de tendência para afinamento, acima do topo do sistema Pirambóia, pode ser interpretado como resultado do retrabalhamento sucessivo dentro de um mesmo tipo de sistema deposicional. Dessa forma, a concentração de argila no Pirambóia inferior pode ser atribuída a processos de sedimentação em interdunas aquáticas e úmidas, que estariam presentes principalmente na metade inferior da formação, bem como à maior quantidade de argila de origem diagenética nas fatias estratigráficas mais antigas. Esta última hipótese é reforçada pelo aumento gradual do teor médio de argila com o aumento da idade relativa das várias fatias estratigráficas analisadas (Figura 50) e pela presença marcante de cimentos filossilicáticos nos arenitos estudados, especialmente nos arenitos do sistema Pirambóia. 


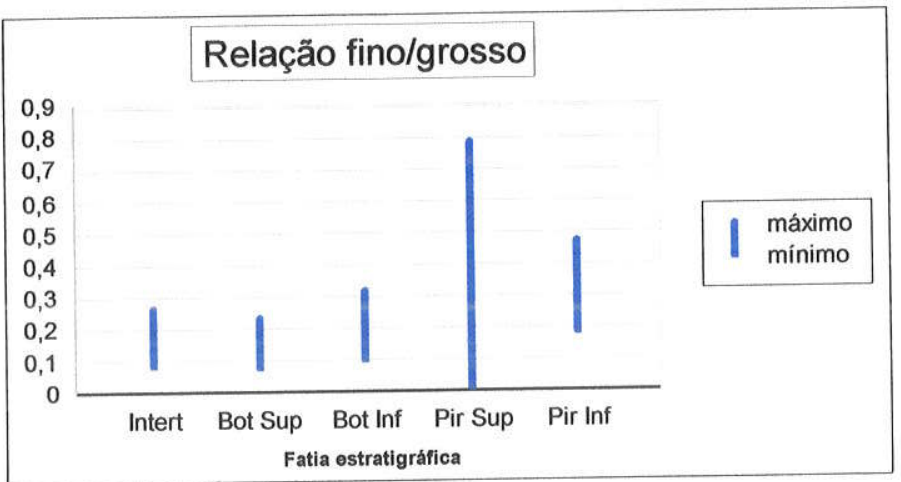

Figura 37 - Gráfico representativo da relação finolgrosso confeccionado com valores de máximo e mínimo para cada fatia estratigráfica. Destacam-se maior amplitude e maior valor máximo no Pirambóia superior.

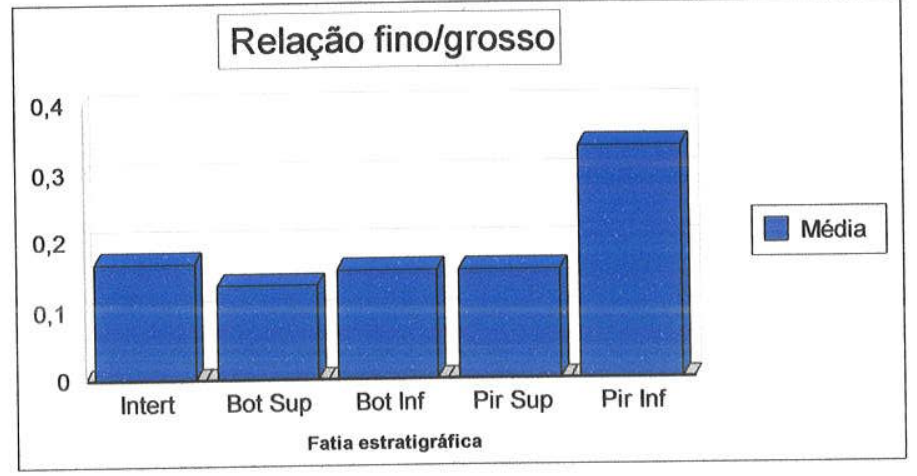

Figura 38 - Gráfico representativo dos valores médios da relação fino/grosso, de acordo com as diferentes fatias estratigráficas. Nota-se maior taxa de finos no Pirambóia inferior.

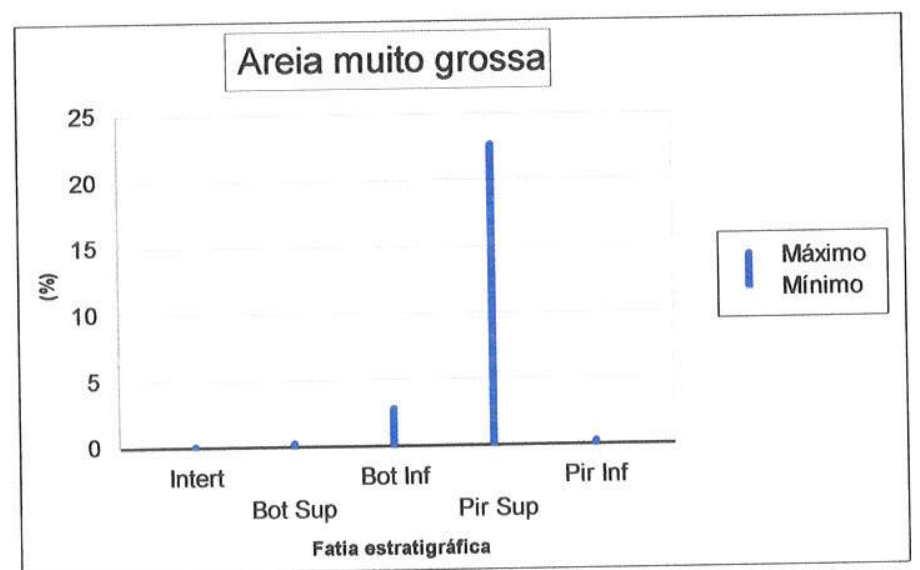

Figura 39 - Gráfico da proporção percentual de areia muito grossa, confeccionado a partir dos valores de máximo e mínimo de cada fatia estratigráfica. Observa-se maior amplitude no Pirambóia superior.

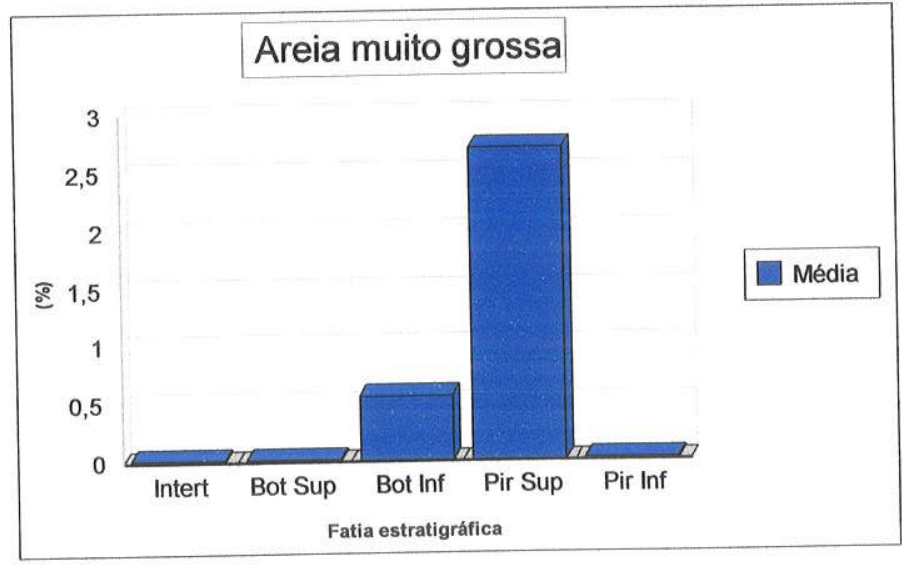

Figura 40 - Gráfico de proporção percentual média da fração areia muito grossa confeccionado de acordo com as fatias estratigráficas. Apresenta forte tendência decrescente do Pirambóia superior ao topo do Botucatu. 


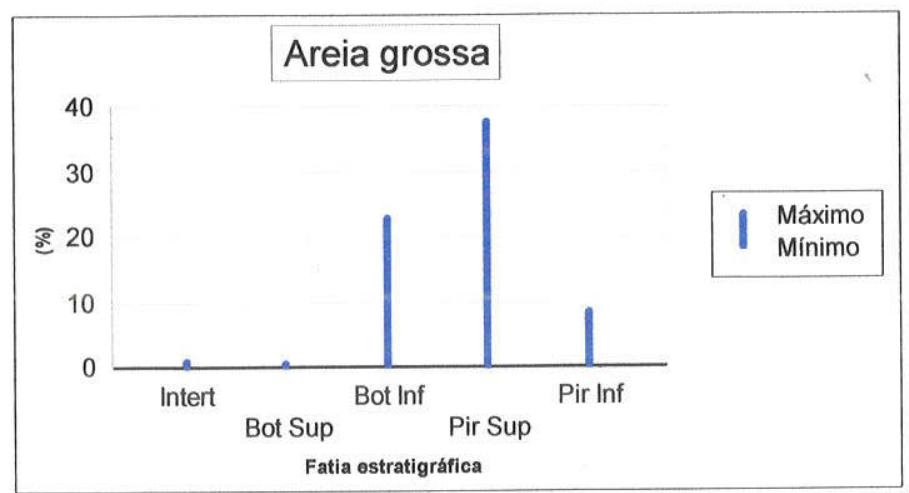

Figura 41 - Gráfico da proporção percentual de areia grossa, confeccionado a partir dos valores de máximo e mínimo de cada fatia estratigráfica. Observa-se maior amplitude no Pirambóia superior.

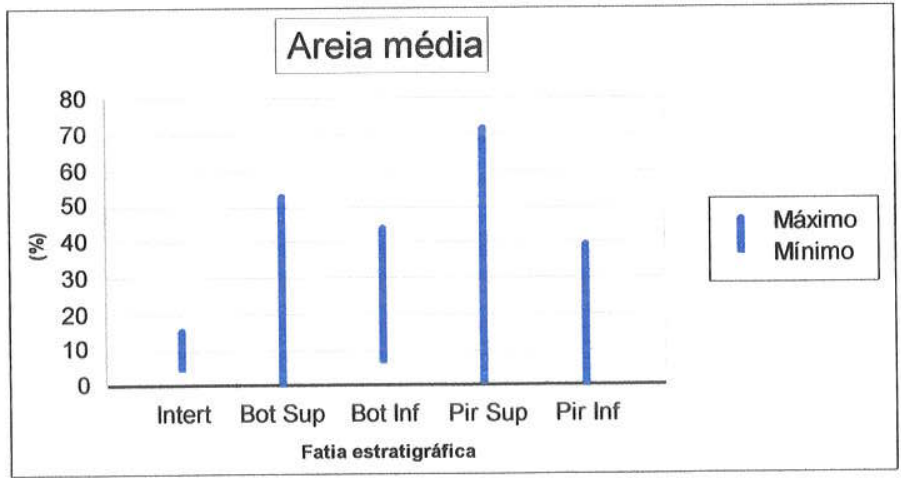

Figura 43 - Gráfico da proporção percentual de areia média, confeccionado a partir dos valores máximo e mínimo de cada fatia estratigráfica. Observa-se maior amplitude no Pirambóia superior, seguido pelo Botucatu superior.

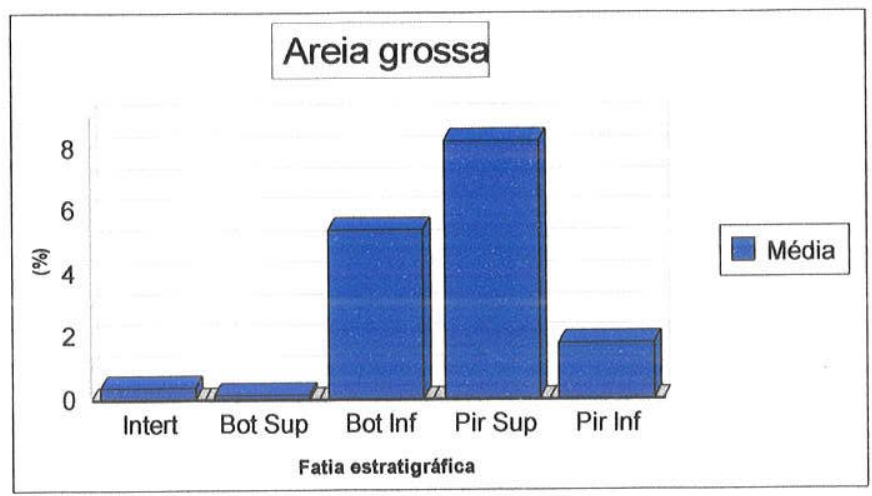

Figura 42 - Gráfico de proporção percentual média da fração areia grossa confeccionado de acordo com as fatias estratigráficas. Apresenta tendência decrescente do Pirambóia superior ao Botucatu superior.

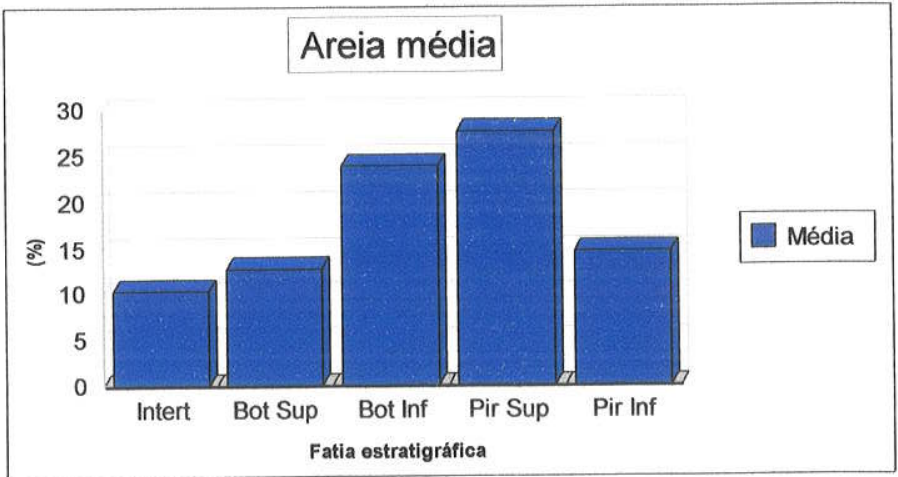

Figura 44 - Gráfico de proporção percentual média da fração areia média confeccionado de acordo com as fatias estratigráficas. Apresenta tendência decrescente do Pirambóia superior ao arenito intertrapp. 


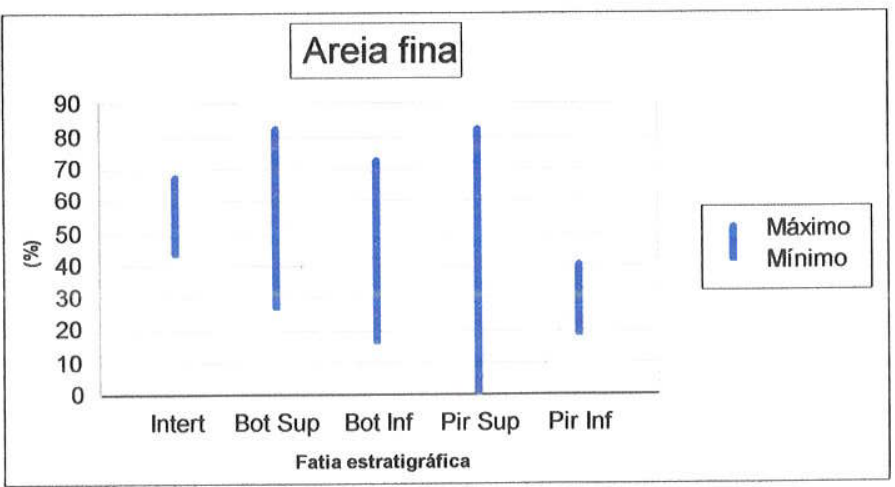

Figura 45 - Gráfico da proporção percentual de areia fina, confeccionado a partir dos valores máximo e mínimo de cada fatia estratigráfica. Observa-se maior amplitude no Pirambóia superior e semelhança entre as fatias do Botucatu, com tendência de aumento dos valores mínimos para o intertrapp.

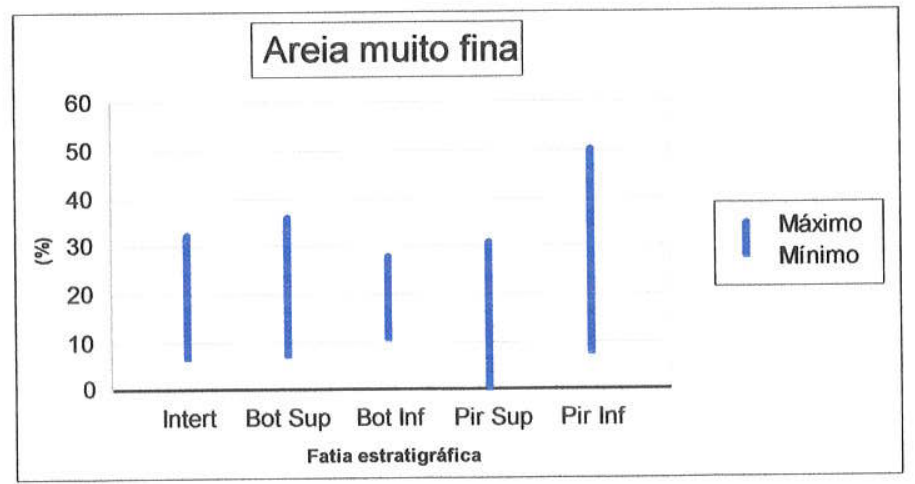

Figura 47 - Gráfico da proporção percentual de areia muito fina, confeccionado a partir de valores de máximo e mínimo de cada fatia estratigráfica. Observa-se maior amplitude no Pirambóia inferior.

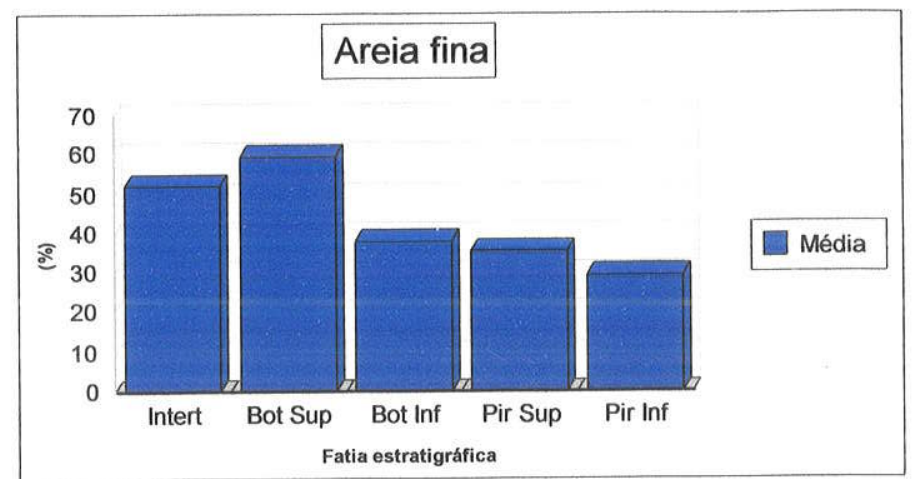

Figura 46 - Gráfico de proporção percentual média da fração areia fina confeccionado de acordo com as fatias estratigráficas. Apresenta tendência crescente do Pirambóia inferior ao Botucatu superior.

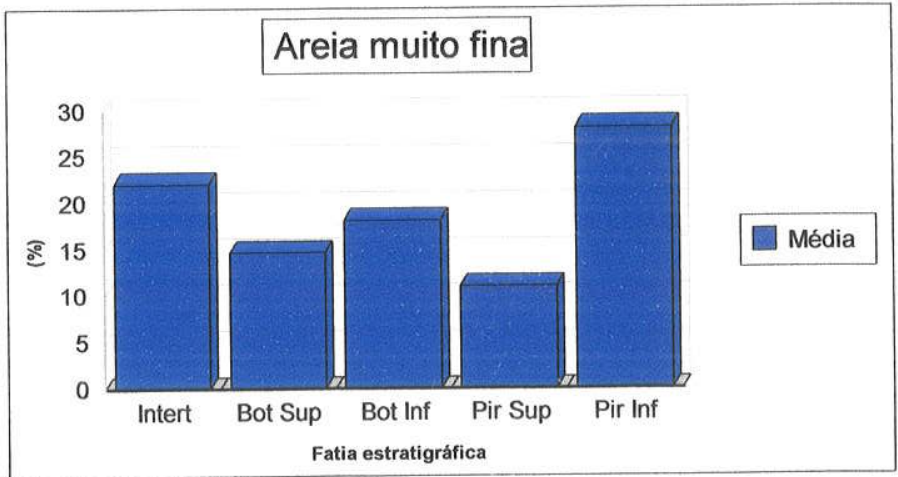

Figura 48 - Gráfico de proporção percentual média da fração areia muito fina, confeccionado de acordo com as fatias estratigráficas. Notar decréscimo abrupto entre o Pirambóia inferior e o superior. 


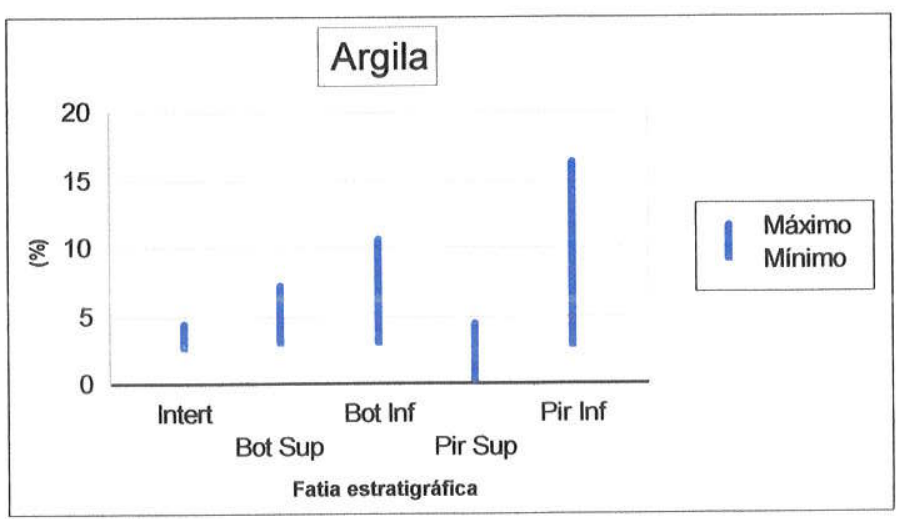

Figura 49 - Gráfico da proporção percentual de argila, confeccionado a partir dos valores máximo e mínimo de cada fatia estratigráfica. Observa-se maior amplitude no Pirambóia inferior. Notar tendência de decréscimo nos valores máximos estratigrafia acima, com exceção do Pirambóia superior.

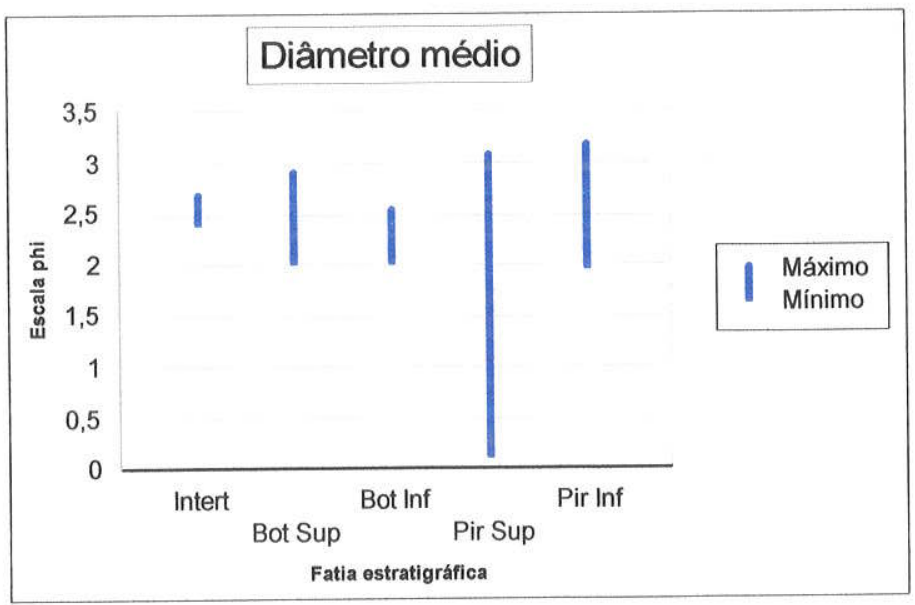

Figura 51 - Gráfico de amplitude do parâmetro diâmetro médio nas diferentes fatias estratigráficas. Destaca-se o valor de amplitude acentuado no Pirambóia superior.

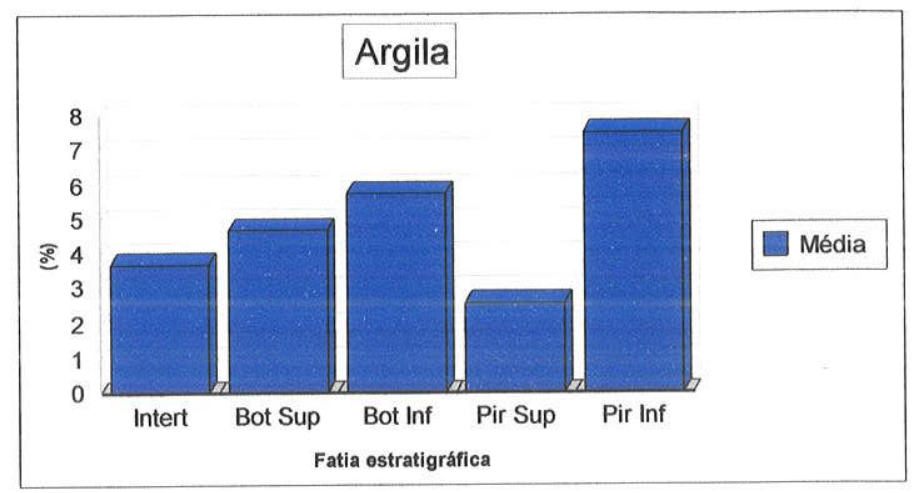

Figura 50 - Gráfico de proporção percentual média da fração argila confeccionado de acordo com as fatias estratigráficas. Apresenta tendência decrescente do Pirambóia inferior ao Botucatu superior, com decréscimo abrupto no Pirambóia superior.

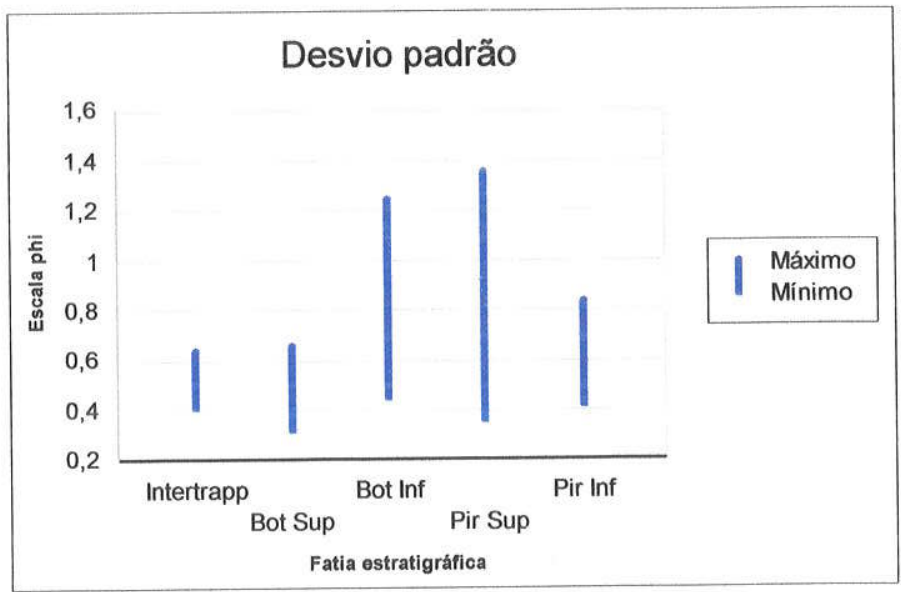

Figura 52 - Gráfico de amplitude do parâmetro desvio padrão da distribuição de freqüências da fração areia nas diferentes fatias estratigráficas. Destaca-se o valor acentuado no Pirambóia superior e Botucatu inferior, decrescendo daí em direção ao topo da sucessão estudada. 


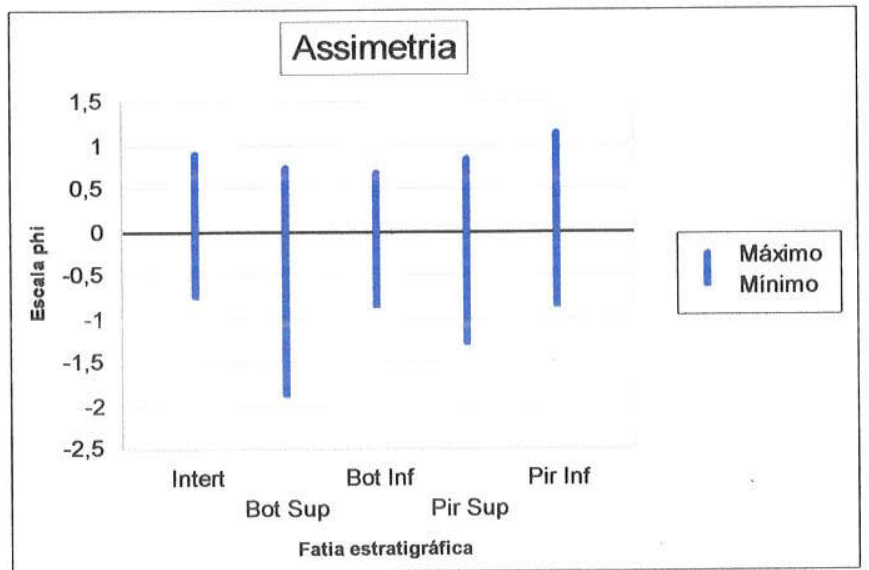

Figura 53 - Gráfico de amplitude do parâmetro assimetria da distribuição de freqüências da fração areia nas diferentes fatias estratigráficas. Destacase a tendência de maior amplitude no Botucatu superior.

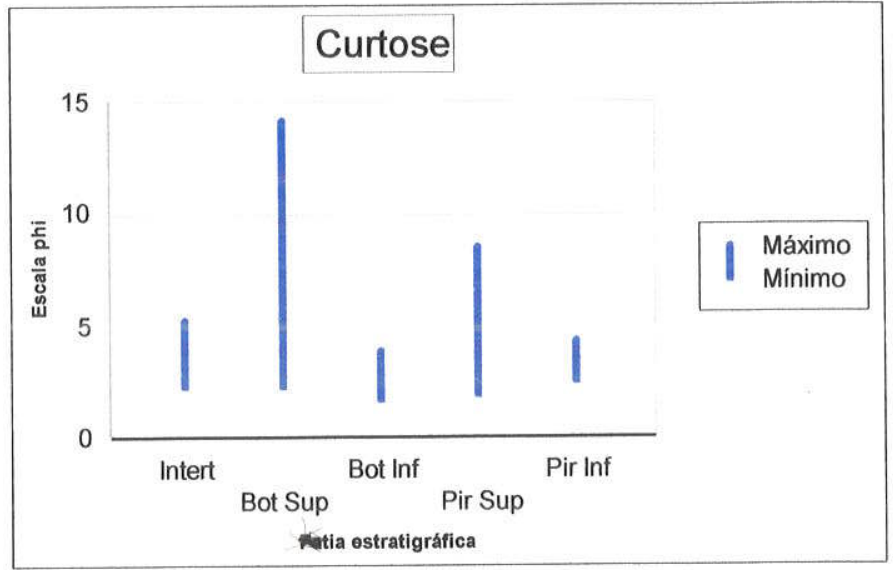

Figura 54 - Gráfico de amplitude do parâmetro curtose da distribuição de freqüências da fração areia nas diferentes fatias estratigráficas. Destaca-se o maior valor de amplitude no Botucatu superior, seguido pelo Pirambóia superior.

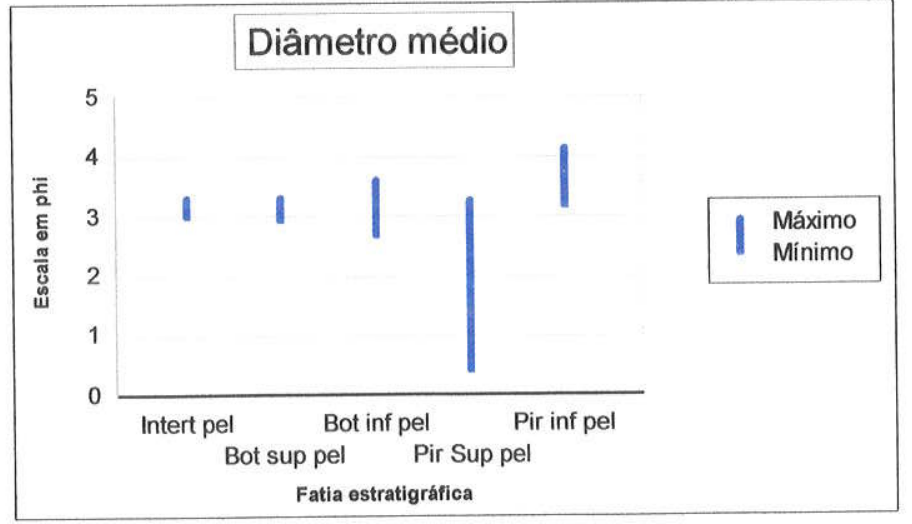

Figura 55 - Gráfico de amplitude do parâmetro diâmetro médio da distribuição de freqüências da fração total nas diferentes fatias estratigráficas. Destacam-se os diâmetros mais grossos no Pirambóia superior, afinando em direção ao Botucatu superior.

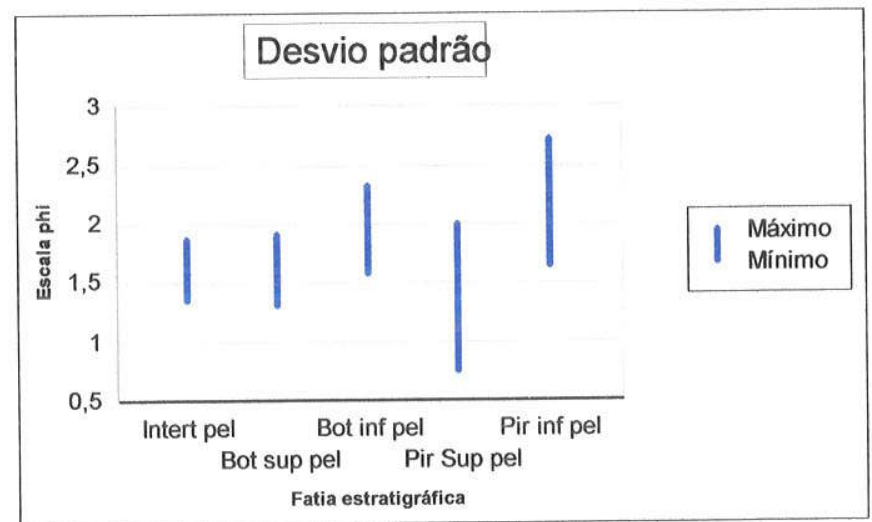

Figura 56 - Gráfico de amplitude do parâmetro desvio padrão da distribuição de freqüências da fração total nas diferentes fatias estratigráficas. Destacam-se os valores acentuados no Pirambóia inferior e superior, decrescendo em direção ao Botucatu superior. 


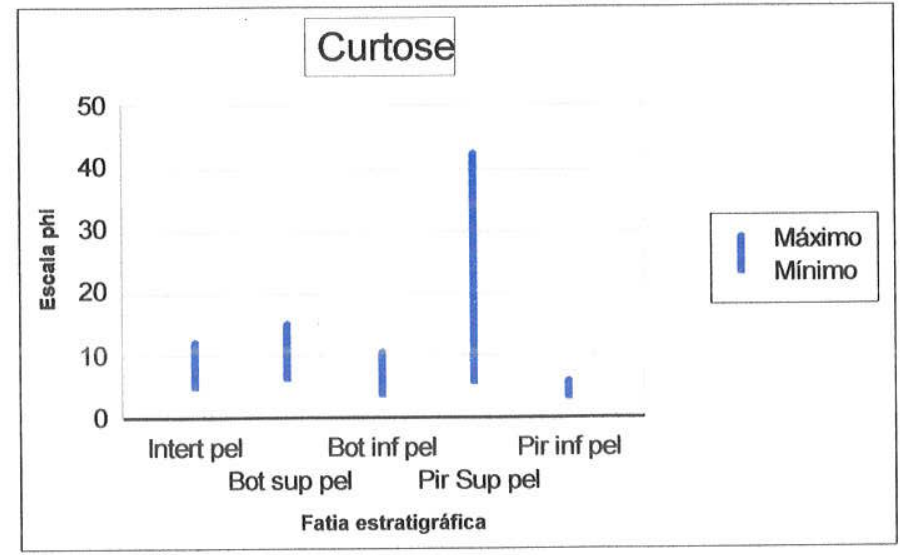

Figura 57 - Gráfico de amplitude do parâmetro curtose da distribuição de freqüências da fração total nas diferentes fatias estratigráficas. Destaca-se a maior amplitude no Pirambóia superior.

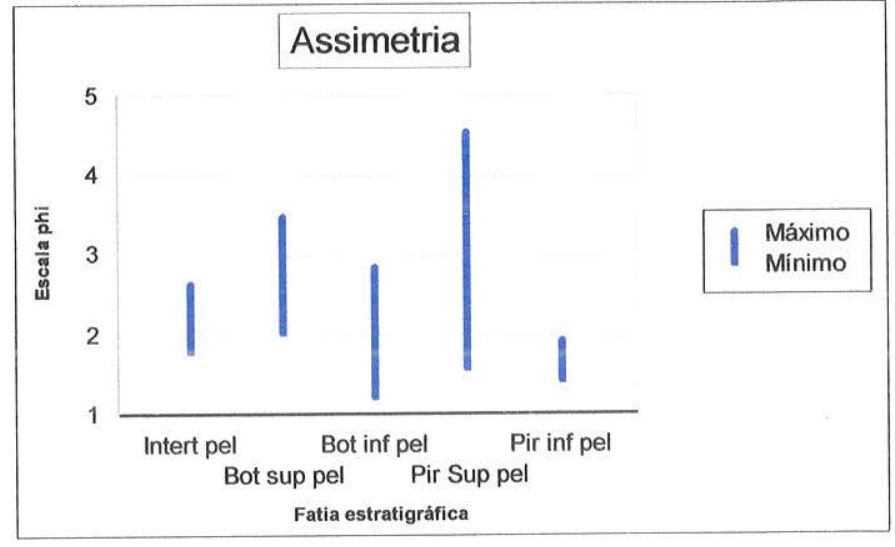

Figura 58 - Gráfico de amplitude do parâmetro assimetria da distribuição de freqüências da fração total nas diferentes fatias estratigráficas. Destacam-se a maior amplitude e o maior valor máximo no Pirambóia superior. 


\subsection{Separação densimétrica e magnética}

Os resultados de análise de minerais pesados e de atração ao imã portátil agrupados por fatia estratigráfica encontram-se representados nas tabelas 04, 05 e 06 .

Para efeito comparativo foram estudadas amostras da unidade imediatamente subjacente ao sistema Pirambóia, coletadas em três diferentes regiões (Tabela 04). 0 resultado indica baixa concentração de minerais pesados na classe granulométrica estudada (areia muito fina), com predomínio da fração não magnética (média $0,23 \%$ ) em relação à magnética (média $0,09 \%$ ). A fração total de pesados, comparada aos sistemas Pirambóia e Botucatu, é escassa.

O sistema Pirambóia inferior (Tabela 05) apresenta no máximo $0,3 \%$ de pesados magnéticos e $1,0 \%$ de pesados não magnéticos, desconsiderando-se a amostra JC.11h (da região norte do Paraná). Uma interpretação para a discrepância representada por esta amostra poderia estar relacionada à faciologia, pois se trata de amostra da base do sistema Pirambóia, com presença marcante da fácies Acb. Outra hipótese seria uma eventual alteração pontual da rocha fonte. E uma terceira hipótese é a da preservação diferencial dos minerais pesados em função da diagênese. Assim, fácies mais argilosas como esta favoreceriam a preservação da assembléia original de minerais pesados.

Os minerais pesados do sistema Pirambóia superior indicam acréscimo, em termos percentuais médio e máximo, de componentes não magnéticos, comparando-se com a metade inferior da unidade. Há um certo equilíbrio entre a fração de magnéticos e não magnéticos, com tendência incipiente de maior concentração de minerais pesados magnéticos.

Os resultados de ensaios de separação densimétrica e magnética na fração areia muito fina e de separação magnética da fração pesada, para o Botucatu (Tabela 06), apresentam, para a fatia inferior, teor máximo de pesados em torno de $0,6 \%$, com valores máximos médios aproximados de $0,2 \%$ de magnéticos e $0,4 \%$ de não magnéticos. As amostras SA.03C, JC.06h e SA.02h foram coletadas no Botucatu superior próximo ao contato com os derrames Serra Geral. O elevado teor de pesados, mais os teores igualmente altos das amostras JC.06h e SA.02h, são indícios de que o Botucatu superior seja pelo menos localmente marcado por uma maior concentração de minerais pesados. 
Tabela 04 - Resultados de ensaio de separação densimétrica na fração areia muito fina e de separação magnética na fração pesada

\begin{tabular}{|c|c|c|c|c|}
\hline \multirow{3}{*}{$\begin{array}{l}\text { CÓDIGO } \\
\text { DA } \\
\text { AMOSTRA }\end{array}$} & \multicolumn{4}{|c|}{ PROPORÇĀO EM MASSA NA FRACAO (\%) } \\
\hline & LEVES & & ES A D O S & \\
\hline & TOTAL & MAGNÉTICOS & Ñ.MAGNÉTICOS & TOTAL \\
\hline JC11en & 99,46 & 0,13 & 0,41 & 0,54 \\
\hline CB01 & 99,89 & 0,02 & 0,09 & 0,11 \\
\hline MS06h & 99,69 & 0,12 & 0,19 & 0,31 \\
\hline Máximo & 99,89 & 0,13 & 0,41 & 0,54 \\
\hline Mínimo & 99,46 & 0,02 & 0,09 & 0,11 \\
\hline Média & 99,68 & 0,09 & 0,23 & 0,32 \\
\hline Dv.padrão & 0,17 & 0,05 & 0,13 & 0,17 \\
\hline
\end{tabular}

'Formações Rio do Rasto e/ou Terezina 
Tabela 05 - Resultados de ensaio de separação densimétrica na fração areia muito fina e de separação magnética na fração pesada

\begin{tabular}{|c|c|c|c|c|}
\hline \multirow{3}{*}{$\begin{array}{l}\text { CÓDIGO } \\
\text { DA } \\
\text { AMOSTRA }\end{array}$} & \multicolumn{4}{|c|}{ PROPORÇĀO EM MASSA NA FRACAO (\%) } \\
\hline & LEVES & & E S A D O S & \\
\hline & TOTAL & MAGNÉTICOS & Ñ.MAGNÉTICOS & TOTAL \\
\hline SA02h & 85,25 & 2,17 & 12,58 & 14,75 \\
\hline PT01c & 99,16 & 0,11 & 0,74 & 0,84 \\
\hline IV05c & 99,63 & 0,27 & 0,11 & 0,37 \\
\hline IV05h & 99,62 & 0,24 & 0,14 & 0,38 \\
\hline IV03c & 99,85 & 0,01 & 0,14 & 0,15 \\
\hline IV03h & 99,50 & 0,16 & 0,34 & 0,50 \\
\hline MS07cf & 99,31 & 0,26 & 0,43 & 0,69 \\
\hline MS07ca & 99,61 & 0,18 & 0,20 & 0,39 \\
\hline MS12h & 99,36 & 0,33 & 0,31 & 0,64 \\
\hline $\mathrm{JCO3b}$ & 99,70 & 0,04 & 0,25 & 0,30 \\
\hline $\mathrm{JCO} 3 \mathrm{v}$ & 99,75 & 0,18 & 0,07 & 0,25 \\
\hline JC10Pi & 99,88 & 0,05 & 0,07 & 0,12 \\
\hline JC11h & 92,56 & 0,47 & 6,97 & 7,44 \\
\hline MS06c & 98,68 & 0,28 & 1,03 & 1,32 \\
\hline GR09h & 99,65 & 0,08 & 0,27 & 0,35 \\
\hline GR10 & 99,87 & 0,04 & 0,08 & 0,13 \\
\hline Máximo & & 0,47 & 6,97 & $\mathbf{7 , 4 4}$ \\
\hline Mínimo & 92,56 & 0,01 & 0,07 & 0,12 \\
\hline Média & 99,08 & 0,18 & 0,74 & 0,92 \\
\hline Dv.padrão & 1,77 & 0,12 & 1,68 & 1,77 \\
\hline & & & & \\
\hline
\end{tabular}

Formação Pirambóia superior

Formação Pirambóia inferior 
Tabela 06 - Resultados de ensaio de separação densimétrica na fração areia muito fina e de separação magnética na fração pesada

\begin{tabular}{|c|c|c|c|c|}
\hline \multirow{3}{*}{$\begin{array}{l}\text { CÓDIGO } \\
\text { DA } \\
\text { AMOSTRA }\end{array}$} & \multicolumn{4}{|c|}{ PROPORÇÃO EM MASSA NA FRACAO (\%) } \\
\hline & LEVES & & E S A D O S & \\
\hline & TOTAL & MAGNÉTICOS & Ñ.MAGNÉTICOS & TOTAL \\
\hline РT02c & 99,51 & 0,45 & 0,04 & 0,49 \\
\hline MS04c & 99,74 & 0,13 & 0,13 & 0,26 \\
\hline $\mathrm{MSO3c}$ & 99,61 & 0,25 & 0,14 & 0,39 \\
\hline MS01c & 99,67 & 0,22 & 0,11 & 0,33 \\
\hline GR14cd & 99,86 & 0,01 & 0,13 & 0,14 \\
\hline IV01c & 99,89 & 0,06 & 0,05 & 0,11 \\
\hline IV01cs & 99,27 & 0,32 & 0,41 & 0,73 \\
\hline JCO6h & 92,11 & 0,03 & 7,86 & 7,89 \\
\hline $\mathrm{JC} 12 \mathrm{~b}$ & 99,47 & 0,17 & 0,36 & 0,53 \\
\hline $\mathrm{SA0} 3 \mathrm{C}$ & 74,88 & 23,70 & 1,42 & 25,12 \\
\hline $\mathrm{SA03cb}$ & 99,71 & 0,02 & 0,28 & 0,29 \\
\hline SA04 & 99,89 & 0,02 & 0,09 & 0,11 \\
\hline IP01 & 99,95 & 0,01 & 0,05 & 0,05 \\
\hline JC01h & 99,77 & 0,10 & 0,13 & 0,23 \\
\hline $\mathrm{JC} 12 \mathrm{a}$ & 99,90 & 0,02 & 0,08 & 0,10 \\
\hline GR11c & 99,43 & 0,14 & 0,43 & 0,57 \\
\hline MSO5c1 & 99,35 & 0,36 & 0,28 & 0,65 \\
\hline MS05c2 & 99,35 & 0,50 & 0,15 & 0,65 \\
\hline MS12c & 99,45 & 0,35 & 0,21 & 0,55 \\
\hline UV02c & 99,95 & 0,00 & 0,04 & 0,05 \\
\hline Máximo & 99,95 & 23,70 & 7,86 & 25,12 \\
\hline Mínimo & 74,88 & 0,00 & 0,04 & 0,05 \\
\hline Média & 98,04 & 1,34 & 0,62 & 1,96 \\
\hline Dv.padrão & 5,56 & 5,13 & 1,69 & 5,56 \\
\hline
\end{tabular}

Arenito intertrapp

Formação Botucatu superior

Formação Botucatu inferior 


\subsection{Descrição e quantificação de minerais pesados}

41 lâminas de grãos de minerais pesados foram submetidas a contagem e descrição. Os valores obtidos encontram-se apresentados nas tabelas 07,08 e 09 . As figuras 60 a 67 ilustram os minerais encontrados e suas feições mais diagnósticas, organizadas de acordo com a posição estratigráfica provável da amostra. As lâminas estudadas referem-se a cinco unidades estratigráficas: Formação Rio do Rasto e/ou Terezina, sistema eólico Pirambóia, sistema eólico Botucatu e arenitos intertrapp. Os resultados referentes à Formação Rio do Rasto (cinco amostras), são apresentados apenas para efeito comparativo. Em relação a esta unidade, as principais características observadas foram as seguintes:

1. Índice de metaestáveis de até $46 \%$, com significativo decréscimo da fração de minerais pesados ultraestáveis (zircão, turmalina e rutilo) em relação aos arenitos Pirambóia e Botucatu.

2. Ocorrência de anatásio euédrico, interpretado como autígeno

3. Ocorrência de $50 \%$ de apatita, na região centro-norte do Paraná

4. Ocorrência de epídoto, cerca de $30 \%$, na região de Jacarezinho

5. Pequena expressividade, em volume, de estaurolita, com máximo de $0,6 \%$.

A contagem de minerais pesados transparentes do sistema Pirambóia inferior caracteriza a presença predominante de minerais ultraestáveis, com tendência para percentuais de metaestáveis mais elevados que no Botucatu. Estes são representados pela associação cianita-sillimanita-epídoto, com ocorrência significativa (cerca de 60\%) de epidoto na amostra JC.11h. As assembléias de minerais pesados do sistema Pirambóia superior apresentam índice de componentes ultraestáveis (ZTR) com amplitude variando 22 pontos percentuais (de $76 \%$ a $98 \%$ ). Entre os demais componentes, alguns minerais metaestáveis destacam-se em abundância, principalmente epídoto e estaurolita. Estaurolita é o mineral metaestável mais freqüente depois dos minerais ultraestáveis (ZTR), sendo porém muito próximo em abundância ao epídoto. Os demais metaestáveis são representados por granada, e excepcionalmente apatita em associação com cianita.

Uma razão plausivel para o índice ZTR elevado nos arenitos Botucatu é o tempo de transporte a que os grãos foram submetidos. O indice ZTR seria diretamente proporcional à distância e/ou tempo de transporte devido à eliminação gradual dos minerais menos resistentes (metaestáveis + instáveis), pelo trabalhamento sucessivo. De 
acordo com esse raciocínio, as areias do sistema Botucatu deve ter sofrido transporte por um tempo relativamente prolongado.

No que se refere às indicações de proveniência, todos os minerais metaestáveis e instáveis encontrados no sistema Pirambóia podem ser considerados típicos, quando não exclusivos, de rochas metamórficas. Em relação ao Botucatu, a escassez de minerais dificulta a interpretação da rocha-fonte primária, mas os poucos minerais metaestáveis presentes apontam para mesma derivação. O super-arredondamento e a elevada proporção de minerais ultraestáveis desta unidade são evidências clássicas de influência de rocha fonte secundária (sedimentar). A similaridade entre as assembléias de pesados dos dois sistemas, associada ao índice ZTR mais elevado da unidade mais nova, são indícios de haver policiclismo do deserto Botucatu, tendo possivelmente como rocha fonte o arenito Pirambóia.

A respeito da dissolução intraestratal, cabe destacar que o principal cimento presente nos arenitos Pirambóia são os argilominerais, associados ou não a óxidos/hidróxidos de ferro, ambas composiçōes mineralógicas suscetíveis à lixiviação pela água, com geração de porosidade. Cabe também lembrar que os afloramentos da Formação Pirambóia amostrados eram formados basicamente por arenitos friáveis, uma demonstração da susceptibilidade da rocha aos agentes intempéricos, e ao mesmo tempo, um indicio de condições favoráveis para a atuação da dissolução pósdeposicional. $O$ fato de alguns minerais pesados metaestáveis ocorrerem preferencialmente em amostras mais finas $(>70 \%$ de silte/argila/areia muito fina), sugere condiçōes de baixa permeabilidade, o que dificultaria a alteração, por diagênese, dos minerais pesados menos resistentes (amostras SA.02h, GR.09h, JC.11h). De qualquer modo, uma avaliação mais segura da hipótese de dissolução pós-deposicional diferencial requer a comparação dos resultados disponiveis com resultados relativos a amostras inalteradas dos mesmos arenitos.

Uma razão para a maior amplitude de oscilação na concentração de minerais ultraestáveis nos arenitos Pirambóia é a dissolução pós-deposicional heterogênea, em contraponto ao Botucatu, onde a freqüente e intensa silicificação eogenética diminui a permeabilidade e conseqüentemente, a susceptibilidade à dissolução. Outra hipótese poderia ser discutida também: a oscilação na concentração de minerais pesados teria relação direta com a maior diversidade faciológica do sistema Pirambóia? Até que ponto as fácies do Pirambóia ricas em argilominerais por exemplo, atuariam no sentido de preservar os minerais pesados da dissolução na telodiagênese? 


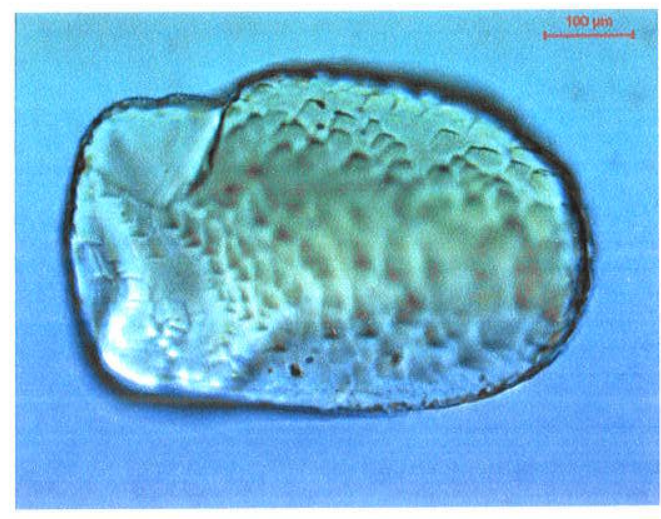

Figura 59 - Grão de apatita arredondado, com formas superficiais poligonais (amostra JC.10pi, Pirambóia inferior, região norte do Paraná).
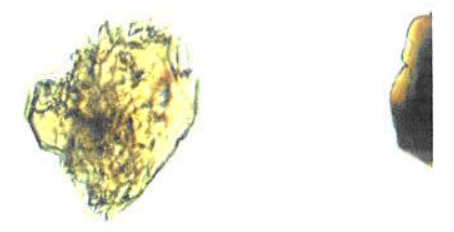

Figura 61 - Grão de estaurolita denteado pertencente à metade inferior do Botucatu, região norte do Paraná (amostra JC.12a).

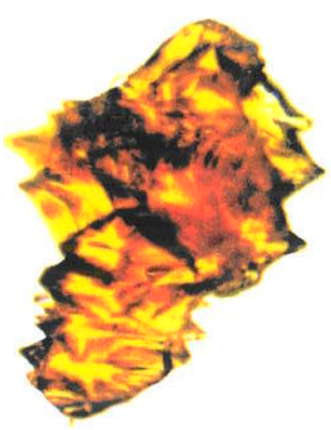

Figura 60 - Grão de estaurolita, subédrico, da amostra JC.03v. Notar denteamento por dissolução pósdeposicional (Pirambóia inferior, região norte do Paraná).

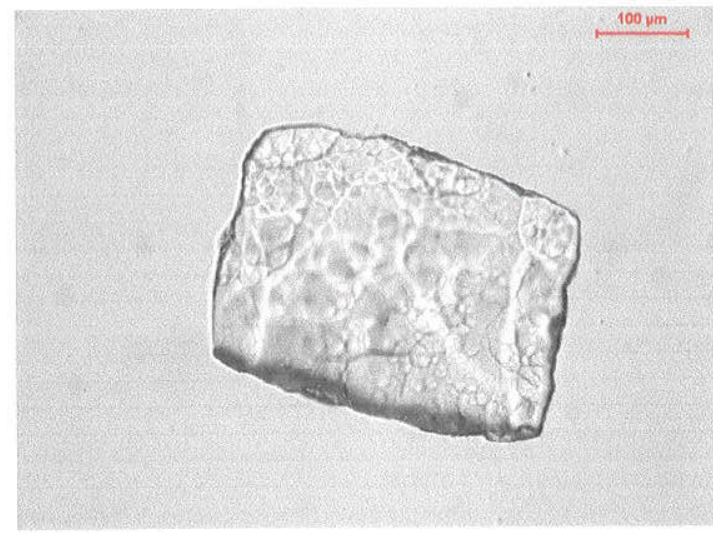

Figura 62 - Granada euédrica de amostra da metade inferior do Botucatu. região norte do Paraná. (Amostra JC.12a). Notar picoteamento superficial, que na granada é mais comumente produzida por dissolução ácida (intemperismo telodiagnético?).

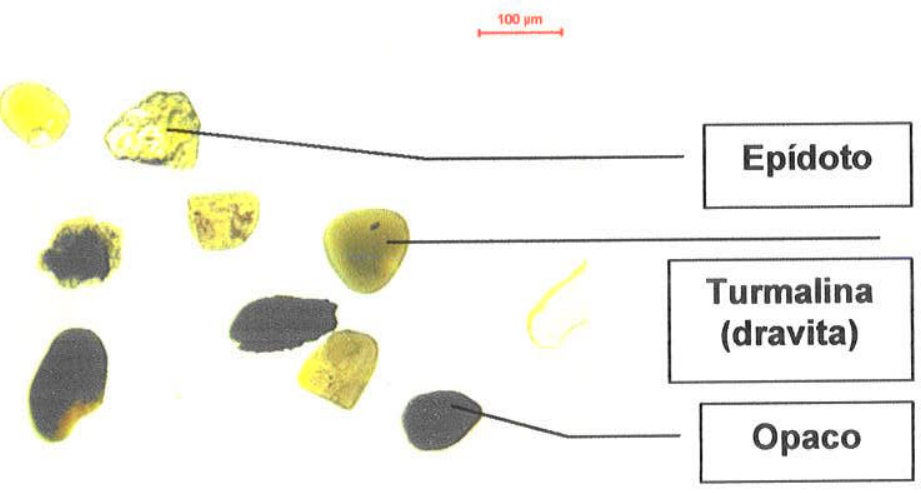

Figura 63 - Grãos arredondados de turmalina (dravita), opacos e epídoto da metade inferior do Botucatu (Amostra JC.12a, região norte do Paraná). 
Figura 64 - Grãos de zircão, bipiramidado e com inclusões (direita), turmalina (centro- esquerda), estaurolita (esquerda) e quartzo, da metade superior do Botucatu (amostra IP.01, região norte do Paraná).

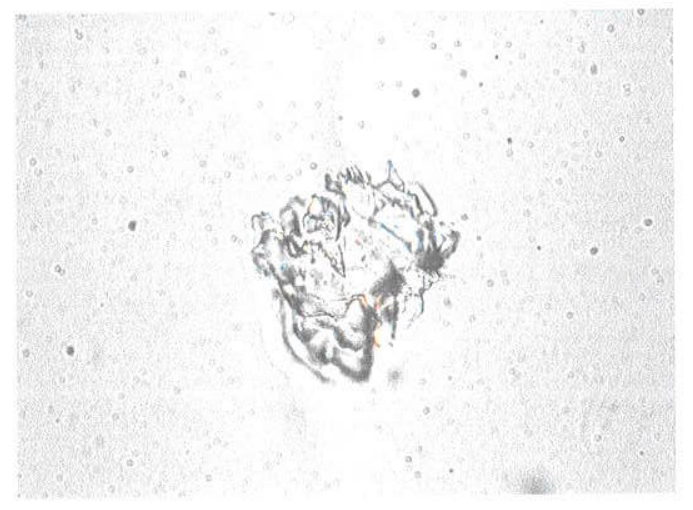

Figura 66 - Grão de apatita arredondado, de amostra da metade superior da Botucatu, região norte do Paraná (grão de areia muito fina - amostra SA.03cb).
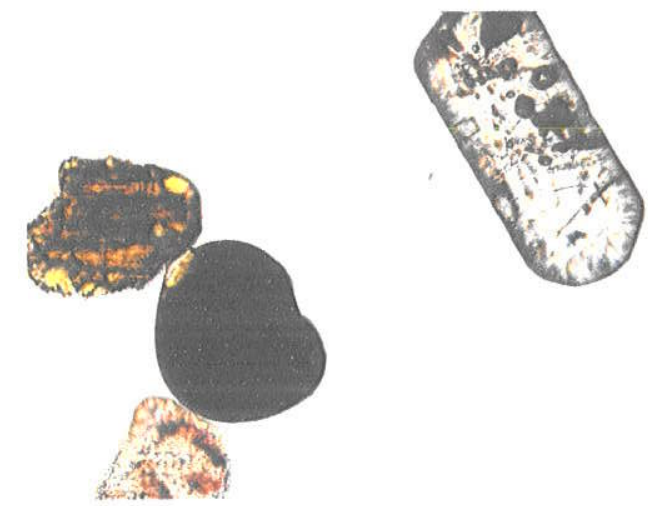

Figura 65 - Cianita com denteamento, observada em amostra da metade superior do Botucatu, da região norte do Paraná (Amostra SA.03cb - grão de areia muito fina). 


\section{Tabela 07 - Resultados de quantificação de minerais pesados $(d>2,85)$ ao microscópio petrográfico}

\begin{tabular}{|c|c|c|c|c|c|c|c|c|c|c|c|c|c|c|c|c|c|c|c|c|c|c|c|c|}
\hline \multirow{2}{*}{$\begin{array}{l}\text { CÓDIGO DA } \\
\text { AMOSTRA } \\
\text { Eq.hidráulico }\end{array}$} & OPAC & LEUC & LIMO & TOTAL & ZIRC & TURM & RUTI & ANAT & ESTA & EPÍD & APAT & ESPIN & SILL & CIAN & CORI & GRAN & IHORN & HIPE & ALTE & TOTAL & \begin{tabular}{|c|} 
TOTAL \\
NO \\
ENSAIO
\end{tabular} & iZTR & iMET & ilNS \\
\hline & 1,00 & 0,01 & 0,05 & & 0,90 & 0,10 & 0,60 & 0,50 & 0,50 & 0,50 & 0,50 & 0,50 & 0,25 & 0,25 & 0,30 & 0,60 & 0,20 & 0,40 & 0,10 & & & & & \\
\hline & & & & & & & & & & & & & & & & & & & & & 655 & 665 & 33.5 & \\
\hline $\begin{array}{c}\text { JC.11en } \\
\text { CB.01 }\end{array}$ & 29,0 & 5,5 & 0,0 & 34,5 & $\begin{array}{l}40,0 \\
61,1\end{array}$ & $\begin{array}{l}20,6 \\
17,7\end{array}$ & 5,8 & 0,0 & 0,6 & 32,9 & 0,0 & 0,0 & 0,0 & 0,0 & 0,0 & 0,0 & 0,0 & 0,0 & $\begin{array}{l}0,0 \\
0,0\end{array}$ & $\begin{array}{l}100,0 \\
100,0\end{array}$ & $\begin{array}{l}65,5 \\
83,6\end{array}$ & $\begin{array}{l}00,0 \\
99,0\end{array}$ & $\frac{3,0}{1,0}$ & $\begin{array}{l}0,0 \\
0,0\end{array}$ \\
\hline $\begin{array}{c}\text { CB.01 } \\
\text { MS.06h }\end{array}$ & $\begin{array}{l}1,0 \\
3,0\end{array}$ & $\begin{array}{l}15,4 \\
17,2\end{array}$ & 0,0 & $\begin{array}{l}16,4 \\
20,2\end{array}$ & $\begin{array}{l}61,1 \\
32,8\end{array}$ & $\begin{array}{l}17,7 \\
6,4\end{array}$ & $\begin{array}{l}20,1 \\
12,8\end{array}$ & $\begin{array}{l}0,0 \\
0,0\end{array}$ & $\begin{array}{l}0,0 \\
0,0\end{array}$ & $\begin{array}{l}0,3 \\
1.6\end{array}$ & $\frac{0,0}{44,8}$ & $\begin{array}{l}0,3 \\
0,0\end{array}$ & $\begin{array}{l}0,0 \\
0,0\end{array}$ & $\begin{array}{l}0,0 \\
0,0\end{array}$ & $\begin{array}{l}0,0 \\
0,0\end{array}$ & $\begin{array}{l}0,3 \\
0,0\end{array}$ & $\begin{array}{l}0,0 \\
0,0\end{array}$ & $\begin{array}{l}0,0 \\
0,0\end{array}$ & $\begin{array}{l}0,0 \\
1,6\end{array}$ & 100,0 & 79,8 & 52,0 & 46,4 & 1,6 \\
\hline MS.06h2 & 3,0 & 24,9 & $\begin{array}{l}0,0 \\
0,0\end{array}$ & $\begin{array}{l}20,2 \\
27,9\end{array}$ & 29,2 & 48,5 & $\begin{array}{l}12,0 \\
18,5\end{array}$ & 1,5 & 0,0 & 1,5 & 0,0 & 0,8 & 0,0 & 0,0 & 0,0 & 0,0 & 0,0 & 0,0 & 0,0 & 100,0 & 72,1 & 97,7 & 2,3 & 0,0 \\
\hline CB.02 & 13,0 & 6,6 & 0,3 & 19,8 & 55,0 & 28,6 & 15,7 & 0,3 & 0,3 & 0,0 & 0,0 & 0,0 & 0,0 & 0,0 & 0,0 & 0,0 & 0,0 & 0,0 & 0,0 & 100,0 & 80,2 & 99,7 & 0,3 & 0,0 \\
\hline MÁXIMO & 29,0 & 24,9 & 0,3 & 34,5 & 61,1 & 48,5 & 20,1 & 1,5 & 0,6 & 32,9 & 44,8 & 0,8 & 0,0 & 0,0 & 0,0 & 0,3 & 0,0 & 0,0 & 1,6 & 100,0 & 83,6 & 99,7 & 46,4 & 1,6 \\
\hline MiNIMO & 1,0 & 5,5 & 0,0 & 16,4 & 29,2 & 6,4 & 5,8 & 0,0 & 0,0 & 0,0 & 0,0 & 0,0 & 0,0 & 0,0 & 0,0 & 0,0 & 0,0 & 0,0 & 0,0 & 100,0 & 65,5 & 52,0 & 0,3 & 0,0 \\
\hline MÉDIA & 9,8 & 13,9 & 0,1 & 23,8 & 43,6 & 24,4 & 14,6 & 0,4 & 0,2 & 7,3 & 9,0 & 0,2 & 0,0 & 0,0 & 0,0 & 0,1 & 0,0 & 0,0 & 0,3 & 100,0 & 76,2 & 83,0 & 16,7 & 0,3 \\
\hline DESV.PADRÃO & 10,5 & 7,2 & 0,1 & 6,6 & 12,4 & 14,0 & 5,0 & 0,6 & 0,3 & 12,8 & 17,9 & 0,3 & 0,0 & 0,0 & 0,0 & 0,1 & 0,0 & 0,0 & 0,6 & 0,0 & 6,6 & 19,9 & 19,4 & 0,6 \\
\hline
\end{tabular}

'Formaçőes Rio do Rasto e/ou Terezina 
Tabela 08 - Resultados de quantificação de minerais pesados $(d>2,85)$ ao microscópio petrográfico

\begin{tabular}{|c|c|c|c|c|c|c|c|c|c|c|c|c|c|c|c|c|c|c|c|c|c|c|c|c|}
\hline \multirow{3}{*}{$\begin{array}{l}\text { CÓDIGO DA } \\
\text { AMOSTRA } \\
\text { Eq.hidráulico }\end{array}$} & \multicolumn{4}{|c|}{$\begin{array}{l}\text { GRUPO DOS MINERAIS } \\
\text { OPACOS, MICÁCEOS } \\
\text { OU BIOCLÁSTICOS: } \\
\text { FREQÜÊNCIAS DE } \\
\text { CONTAGEM NO ENSAIO (\%) }\end{array}$} & \multicolumn{16}{|c|}{$\begin{array}{l}\text { GRUPO DOS MINERAIS TRANSPARENTES NÃO MICÁCEOS: } \\
\text { FREQÜENCIAS DE CONTAGEM NO GRUPO (\%) }\end{array}$} & \multirow{3}{*}{$\begin{array}{c}\text { TOTAL } \\
\text { NO } \\
\text { ENSAIO }\end{array}$} & \multicolumn{3}{|c|}{$\begin{array}{c}\text { ÍNDICES DE } \\
\text { MATURIDADE } \\
\text { QUÍMICA }\end{array}$} \\
\hline & OPAC & LEUC & LIMO & TOTAL & ZIRC & TURM & RUTI & ANAT & ESTA & EPÍD & APAT & ESPIN & SILL & CIAN & CORI & GRAN & HORN & HIPE & ALTE & TOTAL & & iZTR & iMET & ilNS \\
\hline & 1,00 & 0,01 & 0,05 & & 0,90 & 0,10 & 0,60 & 0,50 & 0,50 & 0,50 & 0,50 & 0,50 & 0,25 & 0,25 & 0,30 & 0,60 & 0,20 & 0,40 & 0,10 & & & & & \\
\hline SA.02h & 8,0 & 8,2 & 4,9 & 21,1 & 59,2 & 26,3 & 5,4 & 0,0 & 7,5 & 0,0 & 0,0 & 0,0 & 0,0 & 0,0 & 0,0 & 0,8 & 0,8 & 0,0 & 0,0 & 100,0 & 78,9 & 90,8 & 8,3 & 0,8 \\
\hline IV.11c & 8,0 & 13,3 & 0,0 & 21,3 & 55,9 & 35,6 & 4,2 & 0,0 & 0,0 & 1,7 & 0,0 & 0,8 & 0,0 & 0,0 & 0,0 & 0,0 & 0,0 & 0,0 & 1,7 & 100,0 & 78,7 & 95,8 & 2,5 & 1,7 \\
\hline IV03c & 60,0 & 4,4 & 0,3 & 64,7 & 50,0 & 30,8 & 15,8 & 0,8 & 0,8 & 0,8 & 0,8 & 0,0 & 0,0 & 0,0 & 0,0 & 0,0 & 0,0 & 0,0 & 0,0 & 100,0 & 35,3 & 97,5 & 2,5 & 0,0 \\
\hline IV03h & 60,0 & 9,8 & 0,0 & 69,8 & 30,8 & 36,9 & 30,8 & 0,0 & 0,0 & 0,0 & 0,0 & 0,0 & 0,0 & 0,0 & 0,0 & 1,5 & 0,0 & 0,0 & 0,0 & 100,0 & 30,2 & 98,5 & 1,5 & 0,0 \\
\hline IV.05h & 8,0 & 24,0 & 0,0 & 32,0 & 54,6 & 8,4 & 24,4 & 6,7 & 1,7 & 2,5 & 0,0 & 0,0 & 0,0 & 0,0 & 0,0 & 0,0 & 0,0 & 0,0 & 1,7 & 100,0 & 68,0 & 93,7 & 4,5 & 1,8 \\
\hline IV.05c & 23,0 & 15,1 & 0,0 & 38,1 & 74,8 & 13,3 & 6,7 & 1,5 & 2,2 & 0,0 & 0,0 & 0,0 & 0,0 & 0,0 & 0,0 & 0,0 & 0,0 & 0,0 & 1,5 & 100,0 & 61,9 & 96,2 & 2,3 & 1,5 \\
\hline MS.07cf & 10,0 & 3,6 & 0,0 & 13,6 & 52,9 & 33,5 & 8,9 & 0,0 & 1,6 & 2,1 & 0,0 & 0,0 & 0,0 & 0,0 & 0,0 & 0,0 & 0,0 & 0,0 & 1,0 & 100,0 & 86,4 & 95,3 & 3,7 & 1,0 \\
\hline $\mathrm{MS} 07 \mathrm{ca}$ & 44,0 & 12,1 & 1,6 & 57,7 & 26,9 & 26,9 & 22,2 & 0,0 & 21,3 & 0,9 & 0,0 & 0,0 & 0,0 & 0,0 & 0,0 & 0,0 & 0,0 & 0,0 & 1,9 & 100,0 & 42,3 & 75,9 & 22,2 & 1,9 \\
\hline MS.12h & 10,0 & 21,6 & 0,6 & 32,2 & 19,3 & 56,3 & 14,3 & 0,0 & 7,6 & 0,0 & 0,0 & 0,0 & 0,0 & 0,0 & 0,0 & 0,0 & 0,0 & 0,0 & 2,5 & 100,0 & 67,8 & 89,9 & 7,6 & 2,5 \\
\hline GR.09h & 11,0 & 17,9 & 0,0 & 28,9 & 48,3 & 25,2 & 7,7 & 0,0 & 0,0 & 0,0 & 10,5 & 0,0 & 0,0 & 0,7 & 0,0 & 7,7 & 0,0 & 0,0 & 0,0 & 100,0 & 71,1 & 81,1 & 18,9 & 0,0 \\
\hline JC. $03 b$ & 51,0 & 8,4 & 2,3 & 61,6 & 58,4 & 25,7 & 8,9 & 0,0 & 5,9 & 1,0 & 0,0 & 0,0 & 0,0 & 0,0 & 0,0 & 0,0 & 0,0 & 0,0 & 0,0 & 100,0 & 38,4 & 93,1 & 6,9 & 0,0 \\
\hline JC. $03 \mathrm{v}$ & 8,0 & 2,6 & 0,9 & 11,5 & 10,8 & 71,6 & 0,0 & 0,0 & 17,6 & 0,0 & 0,0 & 0,0 & 0,0 & 0,0 & 0,0 & 0,0 & 0,0 & 0,0 & 0,0 & 100,0 & 88,5 & 82,4 & 17,6 & 0,0 \\
\hline JC.10pi & 4,0 & 17,7 & 0,0 & 21,7 & 50,4 & 33,9 & 13,9 & 0,0 & 0,0 & 0,9 & 0,9 & 0,0 & 0,0 & 0,0 & 0,0 & 0,0 & 0,0 & 0,0 & 0,0 & 100,0 & 78,3 & 98,3 & 1,7 & 0,0 \\
\hline JC. $11 \mathrm{~h}$ & 37,0 & 1,8 & 0,0 & 38,8 & 20,0 & 11,5 & 6,0 & 0,0 & 2,5 & 57,5 & 0,0 & 0,0 & 0,0 & 0,0 & 0,0 & 2,5 & 0,0 & 0,0 & 0,0 & 100,0 & 61,2 & 37,5 & 62,5 & 0,0 \\
\hline GR.10 & 8,0 & 23,4 & 0,8 & 32,3 & 2,5 & 72,8 & 6,2 & 0,0 & 11,1 & 2,5 & 0,0 & 0,0 & 3,7 & 1,2 & 0,0 & 0,0 & 0,0 & 0,0 & 0,0 & 100,0 & 67,7 & 81,5 & 18,5 & 0,0 \\
\hline MÁXIMO & 60,0 & 24,0 & 4,9 & 69,8 & 74,8 & 72,8 & 30,8 & 6,7 & 21,3 & 57,5 & 10,5 & 0,8 & 3,7 & 1,2 & 0,0 & 7,7 & 0,8 & 0,0 & 2,5 & 100,0 & 88,5 & 98,5 & 62,5 & 2,5 \\
\hline MíNIMO & 4,0 & 1,8 & 0,0 & 11,5 & 2,5 & 8,4 & 0,0 & 0,0 & 0,0 & 0,0 & 0,0 & 0,0 & 0,0 & 0,0 & 0,0 & 0,0 & 0,0 & 0,0 & 0,0 & 100,0 & 30,2 & 37,5 & 1,5 & 0,0 \\
\hline MÉDIA & 23,3 & 12,3 & 0,8 & 36,4 & 41,0 & 33,9 & 11,7 & 0,6 & 5,3 & 4,7 & 0,8 & 0,1 & 0,2 & 0,1 & 0,0 & 0,8 & 0,1 & 0,0 & 0,7 & 100,0 & 63,6 & 87,2 & 12,1 & 0,8 \\
\hline DESV.PADRÃO & 20,2 & 7,3 & 1,3 & 18,1 & 20,3 & 18,8 & 8,2 & 1,7 & 6,5 & 14,2 & 2,6 & 0,2 & 0,9 & 0,3 & 0,0 & 2,0 & 0,2 & 0,0 & 0,9 & 0,0 & 18,1 & 15,0 & 15,2 & 0,9 \\
\hline
\end{tabular}

Formação Pirambóia superio

Formação Pirambóia inferior 
Tabela 09 - Resultados de quantificação de minerais pesados $(d>2,85)$ ao microscópio petrográfico

\begin{tabular}{|c|c|c|c|c|c|c|c|c|c|c|c|c|c|c|c|c|c|c|c|c|c|c|c|c|}
\hline \multirow{3}{*}{$\begin{array}{l}\text { CÓDIGO DA } \\
\text { AMOSTRA } \\
\text { Eq.hidráulico }\end{array}$} & \multicolumn{4}{|c|}{$\begin{array}{l}\text { GRUPO DOS MINERAIS } \\
\text { OPACOS, MICÁCEOS } \\
\text { OU BIOCLÁSTICOS: } \\
\text { FREQÜÊNCIAS DE } \\
\text { CONTAGEM NO ENSAIO (\%) }\end{array}$} & \multicolumn{16}{|c|}{$\begin{array}{l}\text { GRUPO DOS MINERAIS TRANSPARENTES NÄO MICÁCEOS: } \\
\text { FREQÜENCIAS DE CONTAGEM NO GRUPO (\%) }\end{array}$} & \multirow{2}{*}{\begin{tabular}{c|} 
TOTAL \\
NO \\
ENSAIO
\end{tabular}} & \multicolumn{3}{|c|}{$\begin{array}{l}\text { ÍNDICES DE } \\
\text { MATURIDADE } \\
\text { QUÍMICA }\end{array}$} \\
\hline & OPAC & LEUC & LIMO & TOTAL & ZIRC & TURM & RUTI & ANAT & ESTA & EPID & APAT & TITA & SILL & CIAN & CORI & GRAN & CPX & HIPE & ALTE & TOTAL & & iZTR & iMET & ilNS \\
\hline & 1,00 & 0,01 & 0,05 & & 0,90 & 0,10 & 0,60 & 0,50 & 0,50 & 0,50 & 0,50 & 0,50 & 0,25 & 0,25 & 0,30 & 0,60 & 0,20 & 0,40 & 0,10 & & & & & \\
\hline PT.02c & 6,0 & 9,6 & 4,8 & 20,4 & 61,7 & 16,1 & 20,1 & 0,0 & 0,7 & 1,3 & 0,0 & 0,0 & 0,0 & 0,0 & 0,0 & 0,0 & 0,0 & 0,0 & 0,0 & 100,0 & 79,6 & 98,0 & 2,0 & 0,0 \\
\hline MS.01c & 6,0 & 3,1 & 0,0 & 9,1 & 51,7 & 8,6 & 0,0 & 0,0 & 39,7 & 0,0 & 0,0 & 0,0 & 0,0 & 0,0 & 0,0 & 0,0 & 0,0 & 0,0 & 0,0 & 100,0 & 90,9 & 60,3 & 39,7 & 0,0 \\
\hline MS. $03 \mathrm{c}$ & 9,0 & 8,3 & 2,8 & 20,0 & 56,0 & 32,8 & 6,0 & 0,0 & 5,2 & 0,0 & 0,0 & 0,0 & 0,0 & 0,0 & 0,0 & 0,0 & 0,0 & 0,0 & 0,0 & 100,0 & 80,0 & 94,8 & 5,2 & 0,0 \\
\hline MS.04c & 1,0 & 3,9 & 1,0 & 5,9 & 96,4 & 0,0 & 0,0 & 0,0 & 3,6 & 0,0 & 0,0 & 0,0 & 0,0 & 0,0 & 0,0 & 0,0 & 0,0 & 0,0 & 0,0 & 100,0 & 94,1 & 96,4 & 3,6 & 0,0 \\
\hline GR.14cb & 23,0 & 2,3 & 4,0 & 29,3 & 4,0 & 34,7 & 0,8 & 0,0 & 60,5 & 0,0 & 0,0 & 0,0 & 0,0 & 0,0 & 0,0 & 0,0 & 0,0 & 0,0 & 0,0 & 100,0 & 70,7 & 39,5 & 60,5 & 0,0 \\
\hline JC.06h & 39,0 & 3,5 & 0,0 & 42,5 & 48,5 & 31,1 & 3,1 & 0,0 & 17,3 & 0,0 & 0,0 & 0,0 & 0,0 & 0,0 & 0,0 & 0,0 & 0,0 & 0,0 & 0,0 & 100,0 & 57,5 & 82,7 & 17,3 & 0,0 \\
\hline JC. $12 b$ & 20,0 & 9,9 & 0,6 & 30,5 & 39,3 & 44,6 & 7,1 & 0,0 & 7,1 & 0,0 & 0,0 & 0,0 & 0,0 & 0,0 & 0,0 & 0,0 & 0,0 & 0,0 & 1,8 & 100,0 & 69,5 & 91,1 & 7,1 & 1,8 \\
\hline SA. $03 \mathrm{cb}$ & 44,0 & 10,3 & 0,0 & 54,3 & 26,6 & 67,2 & 3,9 & 0,0 & 0,0 & 0,0 & 0,8 & 0,0 & 0,0 & 1,6 & 0,0 & 0,0 & 0,0 & 0,0 & 0,0 & 100,0 & 45,7 & 97,7 & 2,3 & 0,0 \\
\hline SA.04 & 62,0 & 3,3 & 2,8 & 68,1 & 4,3 & 62,1 & 0,0 & 0,0 & 0,0 & 25,0 & 0,0 & 0,0 & 0,0 & 0,0 & 0,0 & 8,6 & 0,0 & 0,0 & 0,0 & 100,0 & 31,9 & 66,4 & 33,6 & 0,0 \\
\hline IP.01 & 16,0 & 14,1 & 1,9 & 32,0 & 5,7 & 84,9 & 1,9 & 0,0 & 4,7 & 0,0 & 0,0 & 0,0 & 0,9 & 0,0 & 0,0 & 0,0 & 0,0 & 0,0 & 1,9 & 100,0 & 68,0 & 92,5 & 5,7 & 1,9 \\
\hline MS.11c & 18,0 & 6,8 & 0,2 & 24,9 & 64,6 & 23,4 & 8,3 & 0,0 & 3,6 & 0,0 & 0,0 & 0,0 & 0,0 & 0,0 & 0,0 & 0,0 & 0,0 & 0,0 & 0,0 & 100,0 & 75,1 & 96,4 & 3,6 & 0,0 \\
\hline IV.01c & 16,0 & 10,2 & 4,4 & 30,6 & 57,9 & 35,8 & 5,3 & 0,0 & 0,0 & 0,0 & 1,1 & 0,0 & 0,0 & 0,0 & 0,0 & 0,0 & 0,0 & 0,0 & 0,0 & 100,0 & 69,4 & 98,9 & 1,1 & 0,0 \\
\hline IV.01cs & 8,0 & 11,6 & 4,2 & 23,7 & 43,6 & 32,1 & 12,1 & 0,0 & 9,1 & 0,6 & 0,0 & 0,0 & 0,0 & 0,0 & 0,0 & 0,0 & 0,0 & 0,0 & 2,4 & 100,0 & 76,3 & 87,9 & 9,7 & 2,4 \\
\hline JC.01h & 7,0 & 27,5 & 0,0 & 34,5 & 38,4 & 41,1 & 17,0 & 0,0 & 0,0 & 0,0 & 1,8 & 0,0 & 0,0 & 1,8 & 0,0 & 0,0 & 0,0 & 0,0 & 0,0 & 100,0 & 65,5 & 96,4 & 3,6 & 0,0 \\
\hline JC.12a & 14,0 & 8,7 & 0,0 & 22,7 & 9,7 & 67,7 & 0,8 & 0,0 & 4,0 & 8,9 & 0,0 & 0,0 & 0,0 & 0,0 & 0,0 & 8,1 & 0,0 & 0,0 & 0,8 & 100,0 & 77,3 & 78,2 & 21,0 & 0,8 \\
\hline MS.05c1 & 3,0 & 11,6 & 0,0 & 14,6 & 77,4 & 7,3 & 14,1 & 0,0 & 0,0 & 1,1 & 0,0 & 0,0 & 0,0 & 0,0 & 0,0 & 0,0 & 0,0 & 0,0 & 0,0 & 100,0 & 85,4 & 98,9 & 1,1 & 0,0 \\
\hline MS.05c2 & 6,0 & 7,5 & 0,5 & 14,0 & 79,7 & 9,9 & 6,4 & 0,0 & 0,6 & 3,5 & 0,0 & 0,0 & 0,0 & 0,0 & 0,0 & 0,0 & 0,0 & 0,0 & 0,0 & 100,0 & 86,0 & 95,9 & 4,1 & 0,0 \\
\hline MS.12c & 5,0 & 7,6 & 4,6 & 17,2 & 52,1 & 27,6 & 14,7 & 0,0 & 4,3 & 0,6 & 0,0 & 0,0 & 0,0 & 0,0 & 0,0 & 0,0 & 0,6 & 0,0 & 0,0 & 100,0 & 82,8 & 94,5 & 4,9 & 0,6 \\
\hline GR.11c & 18,0 & 5,1 & 1,7 & 24,7 & 44,0 & 38,1 & 6,7 & 0,0 & 9,7 & 0,0 & 0,7 & 0,0 & 0,0 & 0,7 & 0,0 & 0,0 & 0,0 & 0,0 & 0,0 & 100,0 & 75,3 & 88,8 & 11,2 & 0,0 \\
\hline UV.02c & 17,0 & 14,1 & 2,5 & 33,6 & 2,8 & 62,0 & 0,0 & 0,0 & 35,2 & 0,0 & 0,0 & 0,0 & 0,0 & 0,0 & 0,0 & 0,0 & 0,0 & 0,0 & 0,0 & 100,0 & 66,4 & 64,8 & 35,2 & 0,0 \\
\hline MÁXIMO & 62,0 & 27,5 & 4,8 & 68,1 & 96,4 & 84,9 & 20,1 & 0,0 & 60,5 & 25,0 & 1,8 & 0,0 & 0,9 & 1,8 & 0,0 & 8,6 & 0,6 & 0,0 & 2,4 & 100,0 & 94,1 & 98,9 & 60,5 & 2,4 \\
\hline MiNIMO & 1,0 & 2,3 & 0,0 & 5,9 & 2,8 & 0,0 & 0,0 & 0,0 & 0,0 & 0,0 & 0,0 & 0,0 & 0,0 & 0,0 & 0,0 & 0,0 & 0,0 & 0,0 & 0,0 & 100,0 & 31,9 & 39,5 & 1,1 & 0,0 \\
\hline MÉDIA & 16,9 & 9,0 & 1,8 & 27,6 & 43,2 & 36,4 & 6,4 & 0,0 & 10,3 & 2,1 & 0,2 & 0,0 & 0,0 & 0,2 & 0,0 & 0,8 & 0,0 & 0,0 & 0,3 & 100,0 & 72,4 & 86,0 & 13,6 & 0,4 \\
\hline DESV.PADRÃO & 15,0 & 5,5 & 1,8 & 14,4 & 26,7 & 22,4 & 6,0 & 0,0 & 15,8 & 5,6 & 0,5 & 0,0 & 0,2 & 0,5 & 0,0 & 2,5 & 0,1 & 0,0 & 0,7 & 0,0 & 14,4 & 15,8 & 15,9 & 0,7 \\
\hline
\end{tabular}




\subsection{Seções delgadas}

Os resultados obtidos de análise petrográfica (Tabelas 10 e 11 e Figuras 67 a 81) referem-se à descrição de 42 seções delgadas, representativas da Formação Rio do Rasto, e dos sistemas Pirambóia e Botucatu.

Os arenitos da Formação Rio do Rasto apresentam arcabouço constituído essencialmente por quartzo $(90 \%)$ e feldspato ( $10 \%$ somados microclínio e plagioclásio). O cimento corresponde à cerca de $15 \%$ da amostra e possui caráter ferruginoso. Os grãos de quartzo apresentam extinção ondulante e fraturas incipientes, com muitos vacúolos observados ao maior aumento (150x), arranjados em trilhas. Os cristais de feldspato têm geminação em grade e, alguns, polissintética. Apresentam-se parcialmente argilizados, com filossilicatos seguindo a direção de geminação. A fração granulométrica modal é areia fina $(0,125 \mathrm{~mm}$ a $0,250 \mathrm{~mm})$, com desvio padrão em torno de 0,4 , baixa esfericidade e arredondamento médio. A trama possui orientação sutil, com algum paralelismo entre os grãos. $O$ arcabouço é do tipo aberto, e a compactação mecânica incipiente (contatos intergranulares alongados), com grãos cimentados apenas por óxido de ferro. Este cimento, sacaroidal, encontra-se envolvendo os grãos de quartzo. De acordo com a classificação de Dott (1964), definiu-se a rocha como arenito feldspático.

Nas descrições realizadas para a porção inferior do sistema Pirambóia, encontramse mais de $70 \%$ de grãos de quartzo, e cerca de $10 \%$ de feldspato, com $5 \%$ de cimento e $15 \%$ de poros. $O$ arcabouço é caracterizado por bimodalidade nos termos areia muito fina/areia fina. Caracteriza-se pelo desvio padrão em torno de $0,55 \phi$, seleção granulométrica moderada, baixa esfericidade e grãos subangulosos. $O$ arcabouço é aberto e o cimento, ferruginoso, apresenta-se sacaroidal. Este cimento é caracterizado por fina película envoltória de duas colorações: avermelhada e preta. Este cimento preto encontra-se preferencialmente nos interstícios, preenchendo porosidade secundária. A seguir, seguindo a ordem evolutiva, visivel nas relações de contato, encontra-se envelope ferruginoso avermelhado e sílica microcristalina, que pode ser sacaroidal, mais comumente encontrada junto à crosta ferruginosa, e sem cristalinidade aparente, preenchendo os poros. Cabe ressaltar que dentro dos poros sílica e óxido/hidróxido de ferro preto não coexistem. Outra forma de ocorrência de sílica é crescimento sintaxial de quartzo, que se encontram em contato com linhas de sujeira.

A compactação física e química apresenta-se fraca, dados o fraturamento incipiente e o tipo de contato dos grãos (planares e pontuais). A porosidade mais comum encontrada é a secundária, dos tipos intragranular alveolada (em feldspato), flutuante, 
alongada e móldica. Pode também ser do tipo empacotamento heterogêneo. As maturidades mineralógica e textural foram classificadas como supermatura e submatura respectivamente, enquanto a rocha foi classificada como arenito feldspático, segundo a classificação de Dott (1964).

Na porção superior do sistema Pirambóia, foram descritas cinco lâminas, três das estudadas ao MEV/EED (Item 4.13). Os arenitos desta fatia estratigráfica apresentam de modo geral $65 \%$ de arcabouço, $10 \%$ de cimento e $25 \%$ de poros. $O$ arcabouço contém $85 \%$ de quartzo, seguido por feldspato ( $5 \%$ de microclínio e $5 \%$ de plagioclásio) e até $5 \%$ de fragmentos líticos, na sua maioria de quartzito. A granulometria modal é representada por areia muito fina/areia fina, e valores secundários de areia grossa/areia muito grossa, chegando a seixos, com valores de desvio padrăo altos (entre 1,5 $\phi$ e $2 \phi$ ) e seleção granulométrica ruim. Os grãos do arcabouço apresentam-se com baixa esfericidade e subangulosos, caracterizados pela orientação paralela daqueles grãos alongados, freqüentemente encontrada nas frações finas, com mergulho bem definido, que, em análise preliminar (amostra de măo) representa estrutura risca-de-agulha. $O$ arcabouço é aberto, definido por contatos intergranulares predominantemente planares. $O$ cimento mais abundante é a esmectita ou caulinita microcristalinas (identificadas mais seguramente através do MEV/EED, dada sua semelhança com a sílica sacaroidal na análise por microscopia óptica), seguidas por sílica (sobrecrescimento de quartzo e calcedônia) e óxido/hidróxido de ferro sacaroidal. $O$ anatásio, interpretado como autígeno, encontra-se euédrico e totalmente envolto por óxido/hidróxido de ferro. Caracterizou-se a maturidade textural como submatura a imatura, em função da má seleção, e a rocha, como arenito lítico nos critérios de Dott (1964). A porosidade secundária é dos tipos: alveolar (honeycomb), com grãos flutuantes e alongada. Os cimentos desta porção do sistema Pirambóia representam cerca de $10 \%$ da rocha e podem envolver totalmente os grãos e/ou preencher interstícios. A ordem sugerida de geração dos cimentos é: película ferruginosa, sobrecrescimento de quartzo, argilo mineral microcristalino (esmectita ou paligorskita), silica (calcedônia sacaroidal e quartzo) e caulinita (Tabela 10). Confirmada esta seqüência, o sistema Pirambóia refletiria uma história diagenética mais complexa que o sistema Botucatu. Atribui-se esta diferença à dissolução intraestratal preferencial no sistema Pirambóia, através da prolongada percolação pós-deposicional de águas. Este processo poderia explicar, por exemplo, os grãos de feldspato alveolados e alteração de minerais metaestáveis.

Descrições do sistema Botucatu inferior apontam para um arcabouço essencialmente constituído por grãos de quartzo com extinção ondulante com vacúolos. 
Os grãos caracterizam-se pela boa seleção e pela elevada maturidade textural e mineralógica. A granulometria modal não ultrapassa a fração areia média. 0 arredondamento é marcante. A cimentação inclui películas de óxido/hidróxido de ferro, sobrecrescimento de quartzo e argilominerais, seja esmectita seja caulinita (Tabela 11). Um terceiro tipo seriam óxidos de ferro sacaroidais intersticiais. Há forte segregação granular quanto à forma, ao empacotamento e à cimentação. Classificam-se em sua maioria como quartzo arenitos ou, mais raramente, como arenitos feldspáticos.

Dos arenitos intertrapp, descreveram-se quatro lâminas, todas de amostras silicificadas, com forte tenacidade em amostras de mão, coletadas na região centro-norte do Paraná (pontos MS.09, IV.09, MS.03c e PT.03c). Predominam os tipos de granulometria modal areia fina/muito fina, com ocorrência restrita de areia média. Embora a granulometria modal seja relativamente homogênea, o desvio padrão global do arcabouço atinge valores desde $0,35 \phi$ a $1 \phi$. As demais características são semelhantes ao sistema Botucatu, como cimentação por sílica microcristalina, arcabouço aberto, fraca compactação mecânica, além de desenvolvimento significativo de porosidade secundária e presença quase que exclusivamente de quartzo no arcabouço, quase sempre, com crescimento secundário de sílica. Destaca-se o registro eventual de calcedônia fibrosa com elongação positiva (quartzina), feição sugestiva de cimentação precoce em condições evaporíticas. 
Tabela 10. Ordem sugerida para os processos diagenéticos que atuaram no sistema Pirambóia.

\begin{tabular}{||c|c|c|c|}
\cline { 2 - 4 } \multicolumn{1}{c|}{} & \multicolumn{3}{c|}{ ESTÁGIOS } \\
\hline Processos & Eodiagênese & Mesodiagênese & Telodiagênese \\
\hline $\begin{array}{c}\text { Oxido/hidóxido de } \\
\text { ferro sacaroidal }\end{array}$ & & & \\
\hline $\begin{array}{c}\text { Argilomineral } \\
\text { (esmectita) }\end{array}$ & - & & \\
\hline $\begin{array}{c}\text { Argilomineral } \\
\text { (caulinita) }\end{array}$ & & & \\
\hline $\begin{array}{c}\text { Sílica } \\
\text { (sobrecrescimento) }\end{array}$ & & & \\
\hline $\begin{array}{c}\text { Sílica (microcristalina } \\
\text { sacaroidal) }\end{array}$ & & & \\
\hline $\begin{array}{c}\text { Compactação } \\
\text { mecânica }\end{array}$ & & & \\
\hline $\begin{array}{c}\text { Compactação } \\
\text { química }\end{array}$ & & & \\
\hline
\end{tabular}

Tabela 11. Ordem sugerida para os processos diagenéticos que atuaram no sistema Botucatu, incluindo os arenitos intertrapp.

\begin{tabular}{||c|c|c|c|}
\cline { 2 - 4 } \multicolumn{1}{c|}{} & \multicolumn{3}{c|}{ ESTÁGIOS } \\
\hline Processos & Eodiagênese & Mesodiagênese & Telodiagênese \\
\hline $\begin{array}{c}\text { Oxido/hidróxido de } \\
\text { ferro sacaroidal }\end{array}$ & & & \\
\hline $\begin{array}{c}\text { Sílica } \\
\text { (sobrecrescimento) }\end{array}$ & & & \\
\hline $\begin{array}{c}\text { Argilo mineral } \\
\text { (esmectita) }\end{array}$ & & & \\
\hline $\begin{array}{c}\text { Sílica } \\
\text { (microcristalina } \\
\text { sacaroidal) }\end{array}$ & & & \\
\hline \begin{tabular}{c} 
Sílica (quartzina) \\
\hline Carbonato
\end{tabular} & $(?)$ & & \\
\hline $\begin{array}{c}\text { Compactação } \\
\text { mecânica }\end{array}$ & & & \\
\hline $\begin{array}{c}\text { Compactação } \\
\text { química }\end{array}$ & & & \\
\hline
\end{tabular}




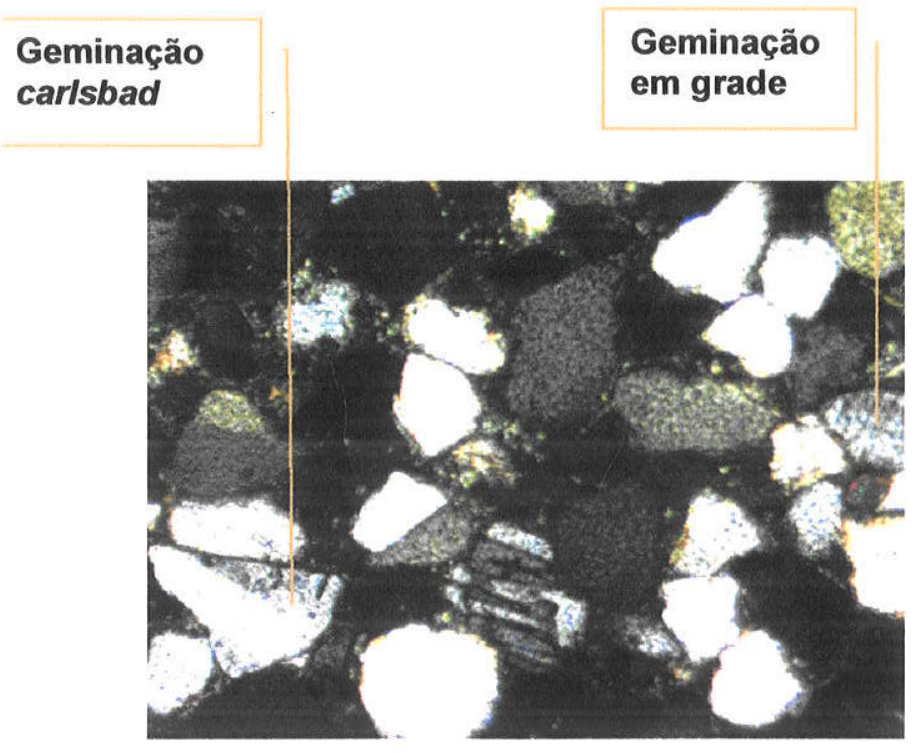

Figura 67 - Grãos de feldspato com geminação em grade e Carlsbad. Amostra JC.07c (metade superior do sistema Botucatu da região norte do Paraná).

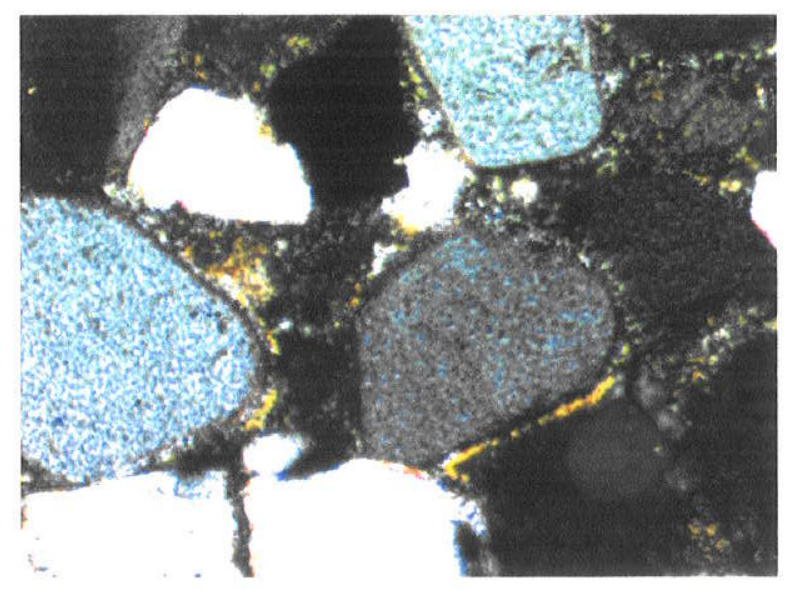

Figura 69 - Característica da cimentação por argilominerais (esmectita/caulinita) de grãos de quartzo (Amostra JC.07c metade superior do sistema Botucatu, região norte do Paraná).

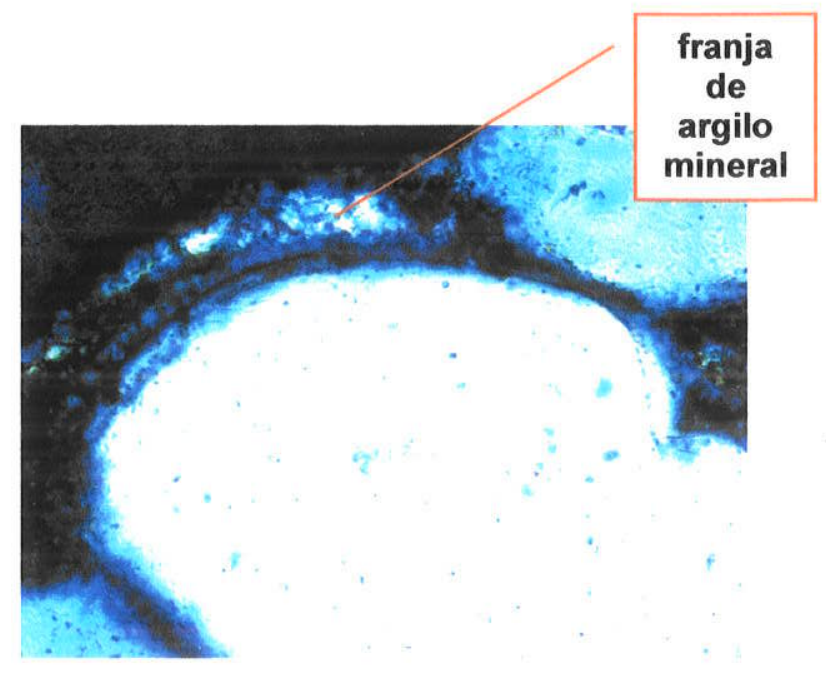

Figura 68 - Aspecto fibro-radiado de argilomineral em contato com grão de quartzo. Amostra JC.07c (Jacarezinho), da metade superior do sistema Botucatu.

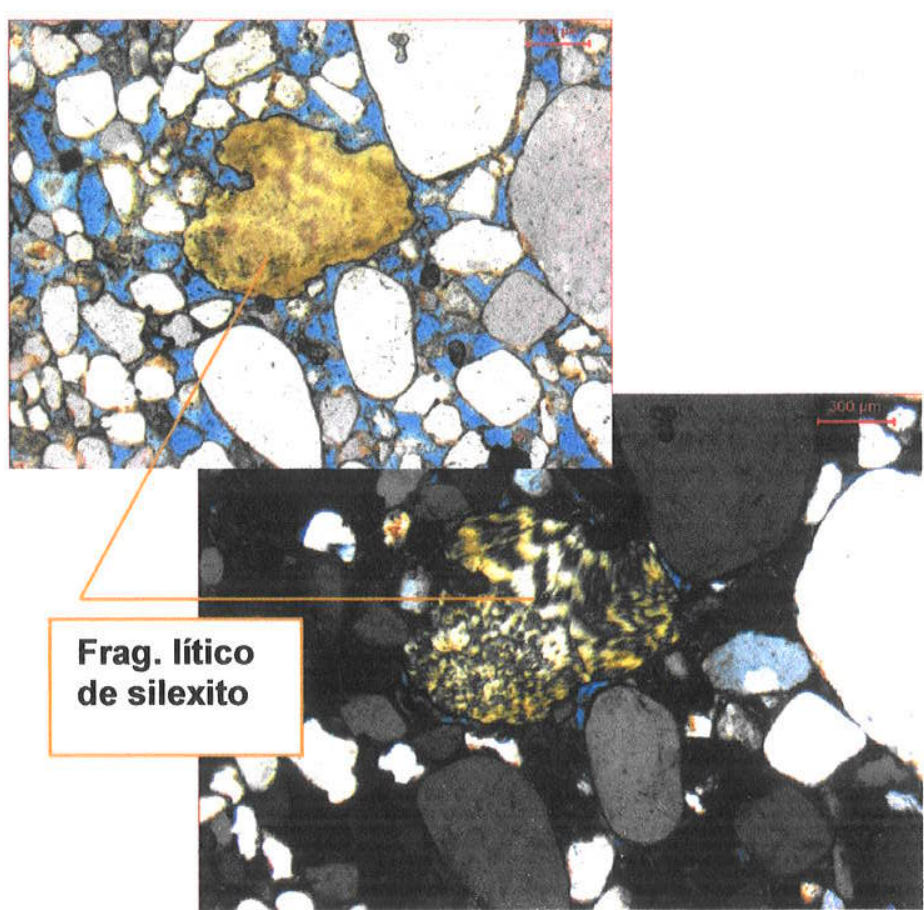

Figura 70 - Fragmento lítico de silexito, formado por calcedônia fibrosa. (nicóis descruzados, acima à esquerda, e nicóis cruzados, abaixo à direita). Amostra MS.05, da metade superior do sistema Pirambóia, serra do Cadeado, região centro-norte do Paraná. 


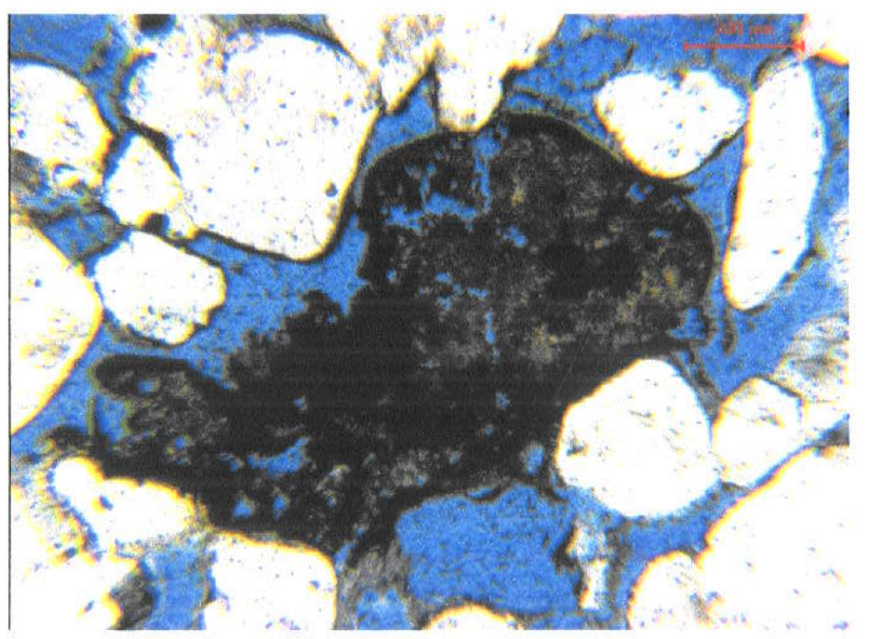

Figura 72 - Dissolução em grão de feldspato. Amostra da metade inferior (JC.11) do sistema Pirambóia na região norte do Paraná.
Figura 71 - Grão de mineral opaco, parcialmente destruído, interpretado como fonte potencial de óxido/hidróxido de ferro para cutículas que recobrem grãos de quartzo do arcabouço. Amostra IV.05, da metade superior do sistema Pirambóia na região centro-norte do Paraná. Notar porosidade móldica na parte inferior, cujos limites estão definidos por óxidos.
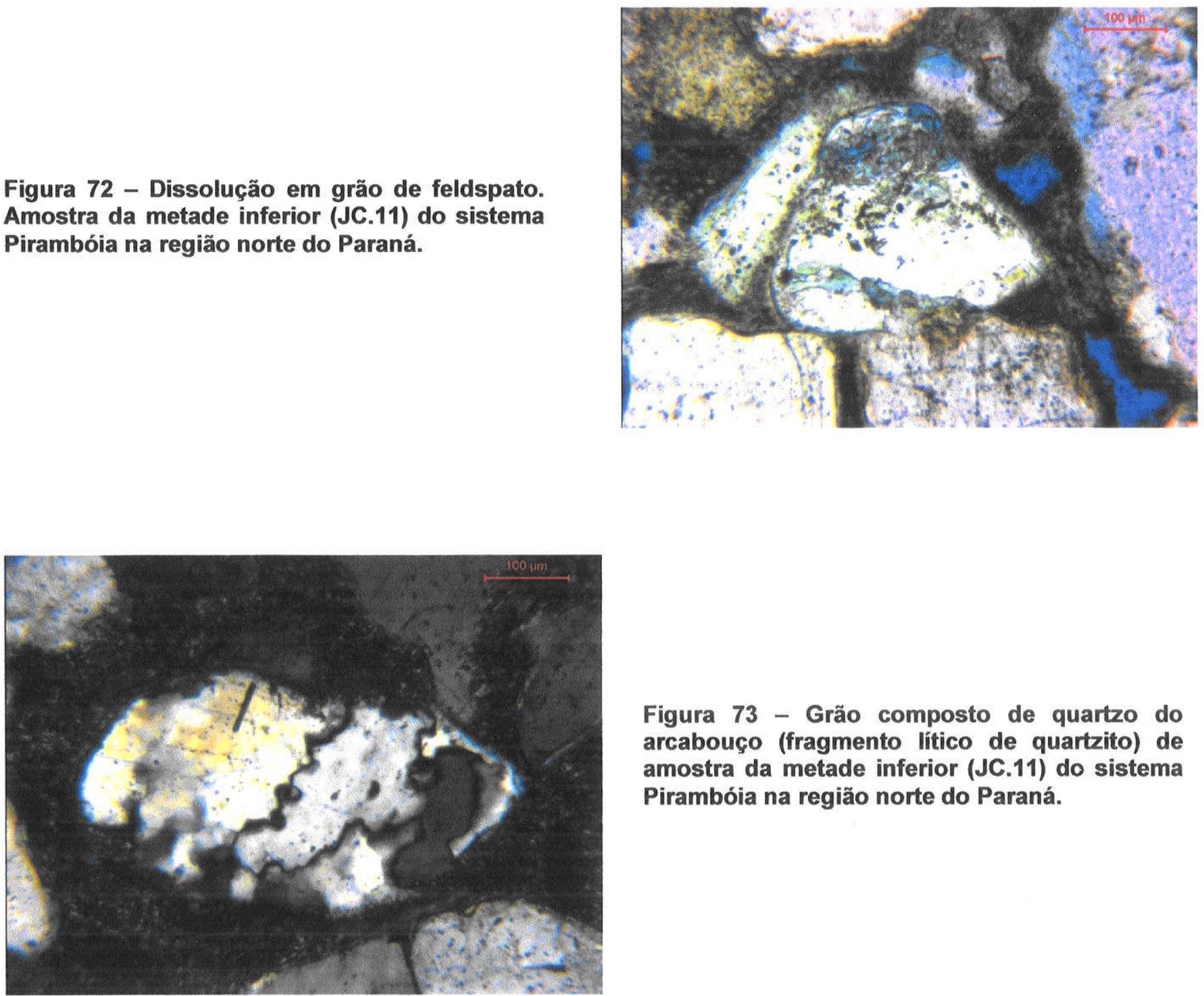

Figura 73 - Grão composto de quartzo do arcabouço (fragmento lítico de quartzito) de amostra da metade inferior (JC.11) do sistema Pirambóia na região norte do Paraná. 
Figura 74 - Relações de cimentação em amostra, da metade inferior (JC.11) do sistema Pirambóia na região norte do Paraná. Argilomineral recobre imediatamente aos grãos de quartzo do arcabouço.

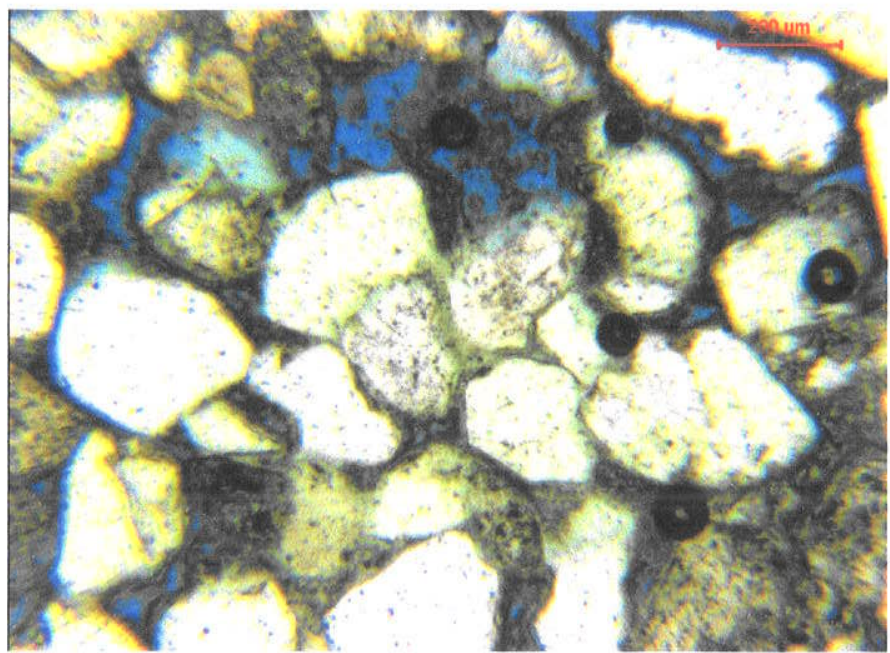

Figura 75 - Grãos de quartzo do arcabouço, e de mineral pesado (ao centro), com franja de argilomineral (provável esmectita) impregnante à superfície dos grãos. Notar porosidade secundária em azul. Amostra GR.09, da metade superior do sistema Pirambóia na região centro-sul do Paraná. Notar angulosidade dos grãos de quartzo.
Figura 76 - Visão geral dos grãos de quartzo do arcabouço em nicóis cruzados, e de argilominerais (provável esmectita) que envolvem os grãos de quartzo. Notar paralelismo dos argilominerais com as superfícies dos grãos, atribuído à compactação mecânica na mesodiagênese. Amostra MS.07, da metade superior do sistema Pirambóia na região centro-norte do Paraná. Notar baixa esfericidade dos grãos de quartzo.

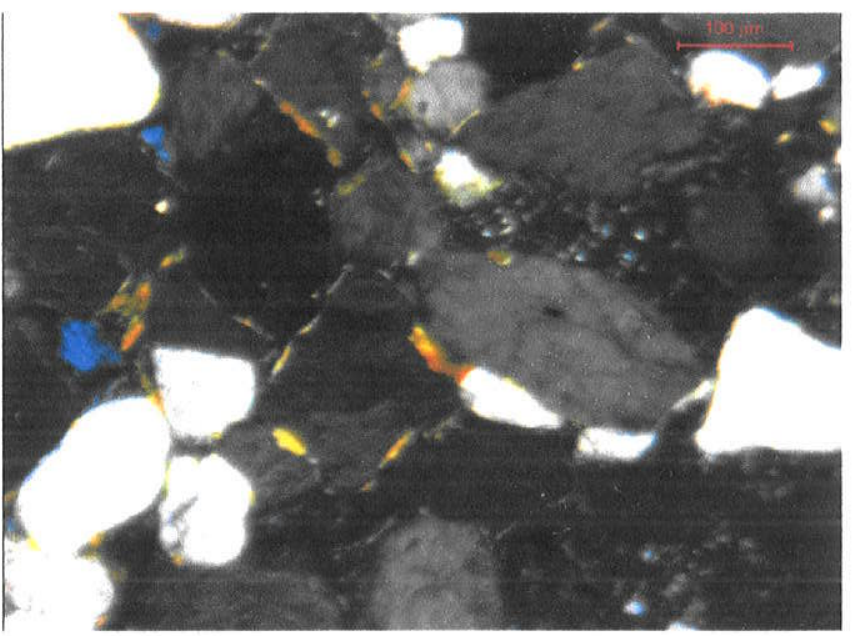




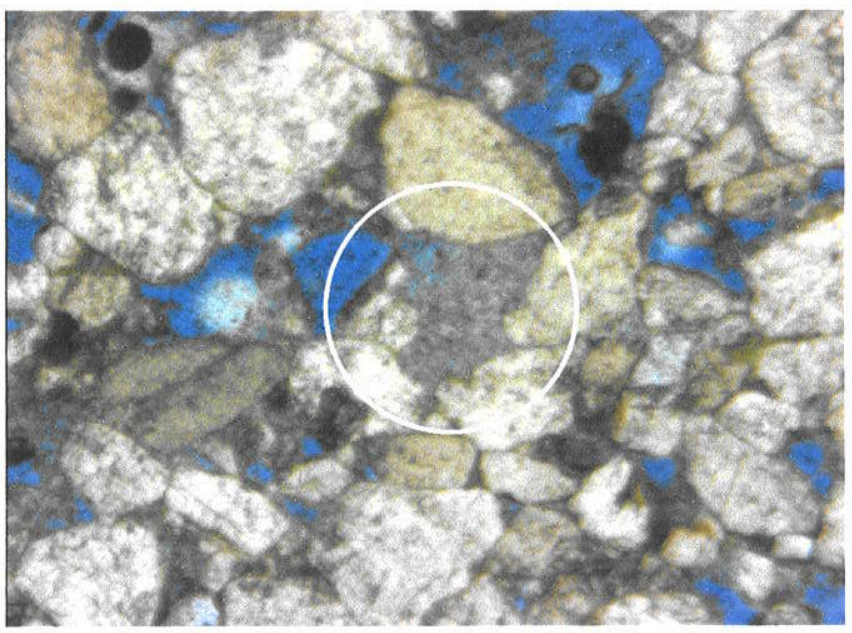

Figura 78 - Detalhe de porosidade móldica e agigantada, isolando grãos do arcabouço (cluster). Observa-se alinhamento de películas de óxido/hidróxido de ferro (setas) seguindo provavelmente geminação polissintética ou clivagem de plagioclásio dissolvido. Amostra GR.09, metade superior do sistema Pirambóia na região centro-sul do Paraná.
Figura 77 - Argilomineral preenchendo porosidade secundária (círculo) e grãos de quartzo angulosos mal selecionados desenvolvendo contatos côncavo-convexos. Amostra GR.09, metade superior do sistema Pirambóia na região centro-sul do Paraná.
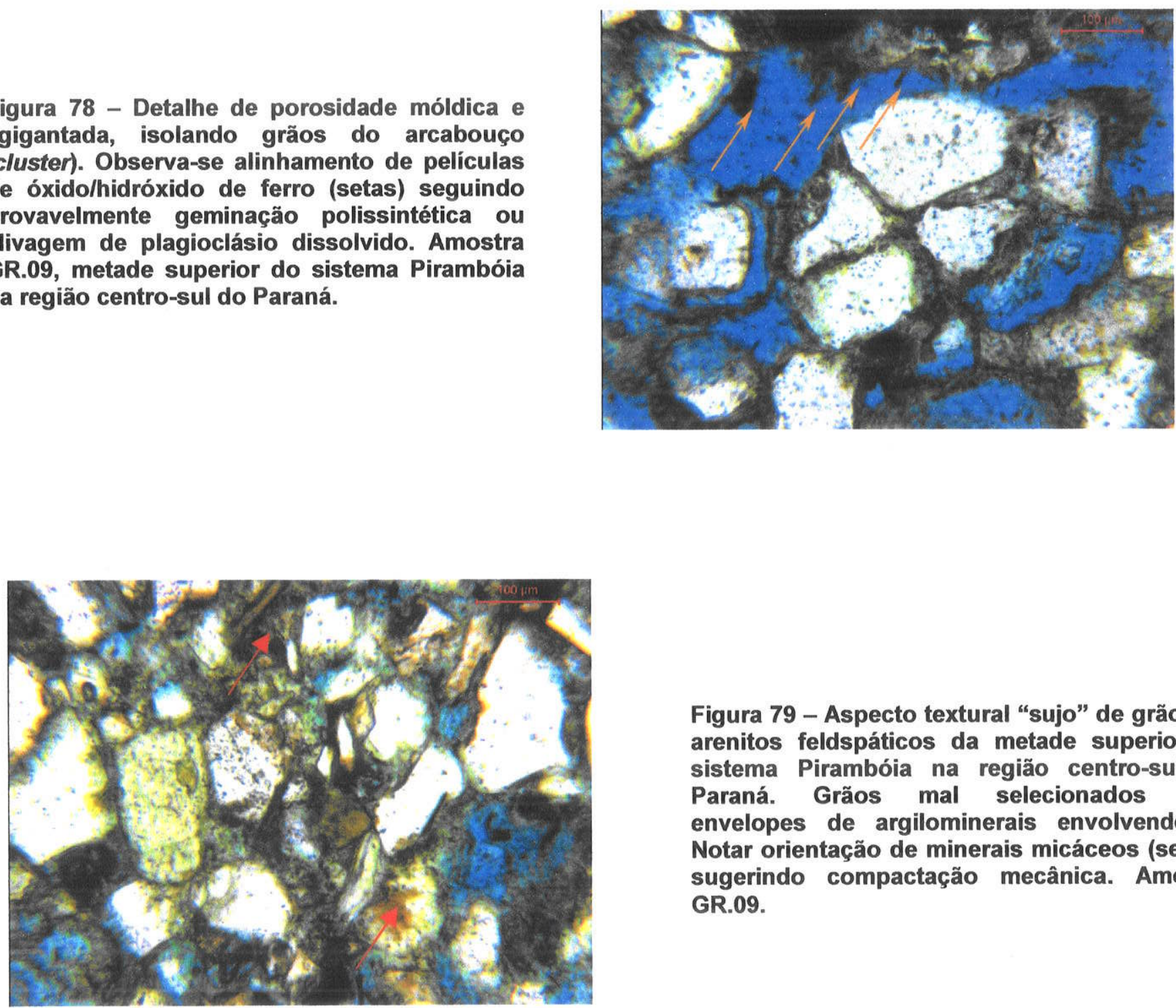

Figura 79 - Aspecto textural "sujo" de grãos de arenitos feldspáticos da metade superior do sistema Pirambóia na região centro-sul do Paraná. Grãos mal selecionados com envelopes de argilominerais envolvendo-os. Notar orientação de minerais micáceos (setas), sugerindo compactação mecânica. Amostra GR.09. 


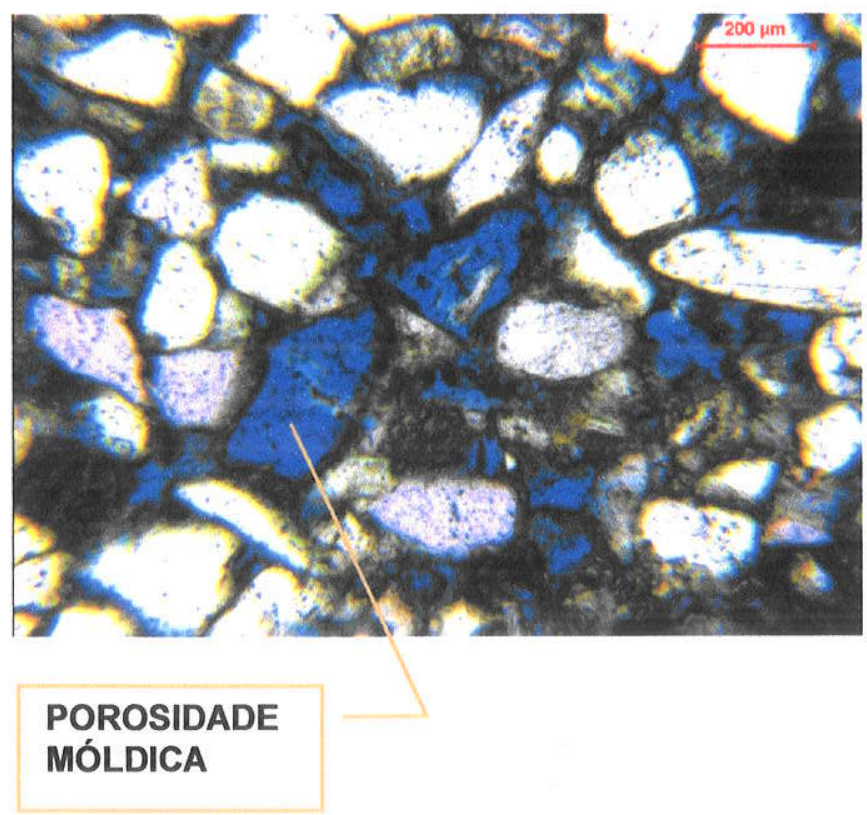

Figura 80 - Detalhe de porosidade móldica, com resquícios do material original orientado, possivelmente de grãos de feldspato do arcabouço. A dissolução desses grãos é atribuída a telodiagênese. Amostra GR.09, da metade superior do sistema Pirambóia na região centro-sul do Paraná.

Figura 81 - Grãos de quartzo cimentados por óxido/hidróxido de ferro de amostra da porção superior do sistema Pirambóia na região centro-norte do Paraná (amostra IV.05). Notar o contorno finamente irregular de alguns grãos, indicativo de dissolução (seta).

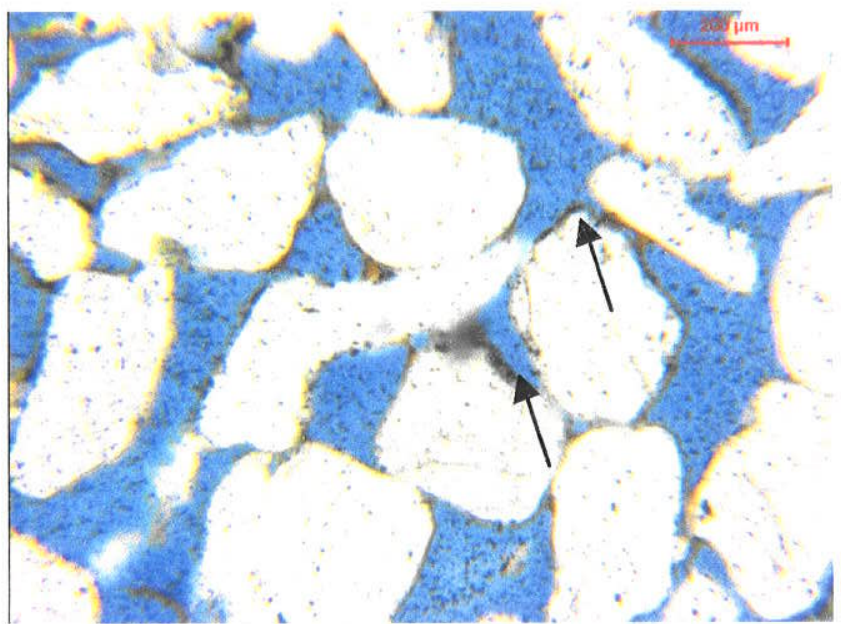




\subsection{Análise ao sistema MEV/EED}

Cinco amostras foram analisadas ao microscópio eletrônico de varredura (MEV) e por espectrometria de energia dispersiva de raios $x$ (EED): três da região norte (Jacarezinho, amostras IP.01hp, JC.07c e JC.11c), uma do centro-norte (Ivaiporã, amostra MS.12a) e uma do centro-sul (Guarapuava, amostra GR.11c). Buscou-se identificar detalhes de microtexturas, quimismo e feições morfológicas mais características do cimento e do arcabouço dos arenitos dos dois sistemas.

Antes de iniciar as sessões de microscopia, procederam-se, em duas amostras da metade superior do Botucatu, testes para identificar qual o tipo de recobrimento ideal (se ouro ou carbono). Os testes permitiram observar que o recobrimento por carbono apresenta vantagens na análise semiquantitativa, mas, em contrapartida, compromete a obtenção de imagens em grandes aumentos. Isto porque nas amostras recobertas com carbono há forte tendência de concentrar elétrons onde haja incidência do feixe, o que gera queima da amostra. Esta concentração é representada por manchas esbranquiçadas na imagem.

A amostra MS.12a corresponde a argila cinza claro coletada na região de Mauá da Serra, centro-norte do Paraná, no contato das formaçōes Pirambóia e Botucatu. Ao microscópio óptico esta argila apresenta-se como franja acinzentada de birrefringência fraca, em contato direto com grãos de quartzo. A caracterização ao difratômetro de raios $x$ e ao MEV/EED permitiu identificar o argilomineral como sendo caulinita (EED indicou presença de $\mathrm{Al}, \mathrm{Si}$ e O). Nas figuras 82 a 85 , é possível observar o arranjo irregular das placas de argila. Estas placas encontram-se dispostas de modo caótico, completamente desmanteladas, sobre grão de quartzo (Figuras 84 e 85). O desmantelamento e a disposição em que foram encontrados os cristálitos de caulinita são sugestivos de processo de lixiviação, atribuídos à ocorrência de telodiagênese. A percolação de água meteórica seria favorecida pelo soerguimento e exposição desses arenitos, e pela presença de descontinuidade gerada pela diferença de porosidade entre os arenitos dispostos acima e abaixo da superficie que continha a lama branca (caulinitização em paraconformidades).

Feições superficiais encontradas em grão de quartzo, sob forma de triângulos irregulares (Figuras 83 a 85), seriam geradas possivelmente por dissolução química durante processos diagenéticos tardios. 


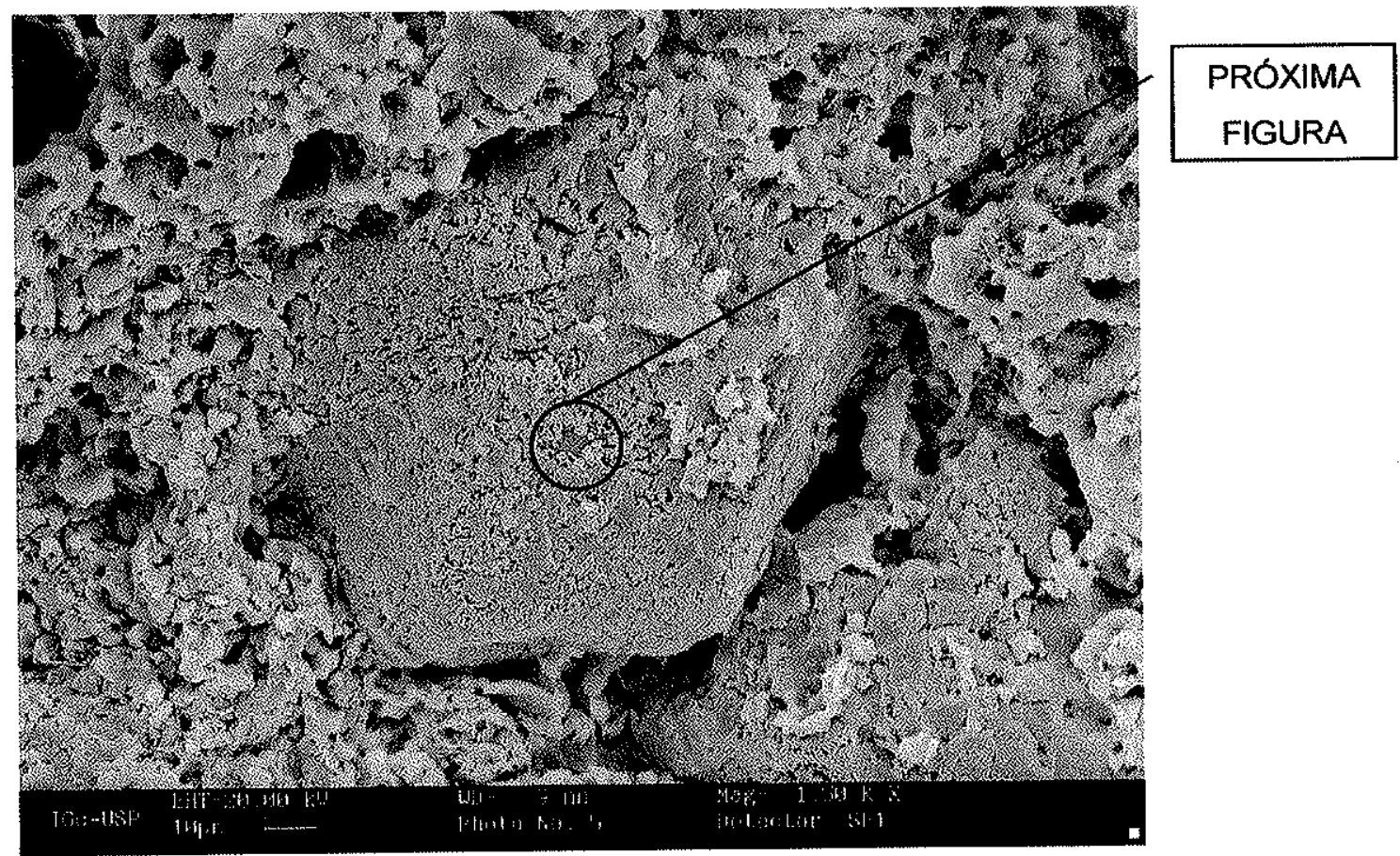

Figura 82 - Grão de quartzo recoberto por argilomineral (amostra MS.12a do topo da Formação Pirambóia, imediatamente abaixo do contato com a Formação Botucatu, região centro-norte do Paraná). Detector de elétrons secundários (SE1), aumento (MAG): 1,5 K X, tensão elétrica (EHT): $20.00 \mathrm{kV}$.

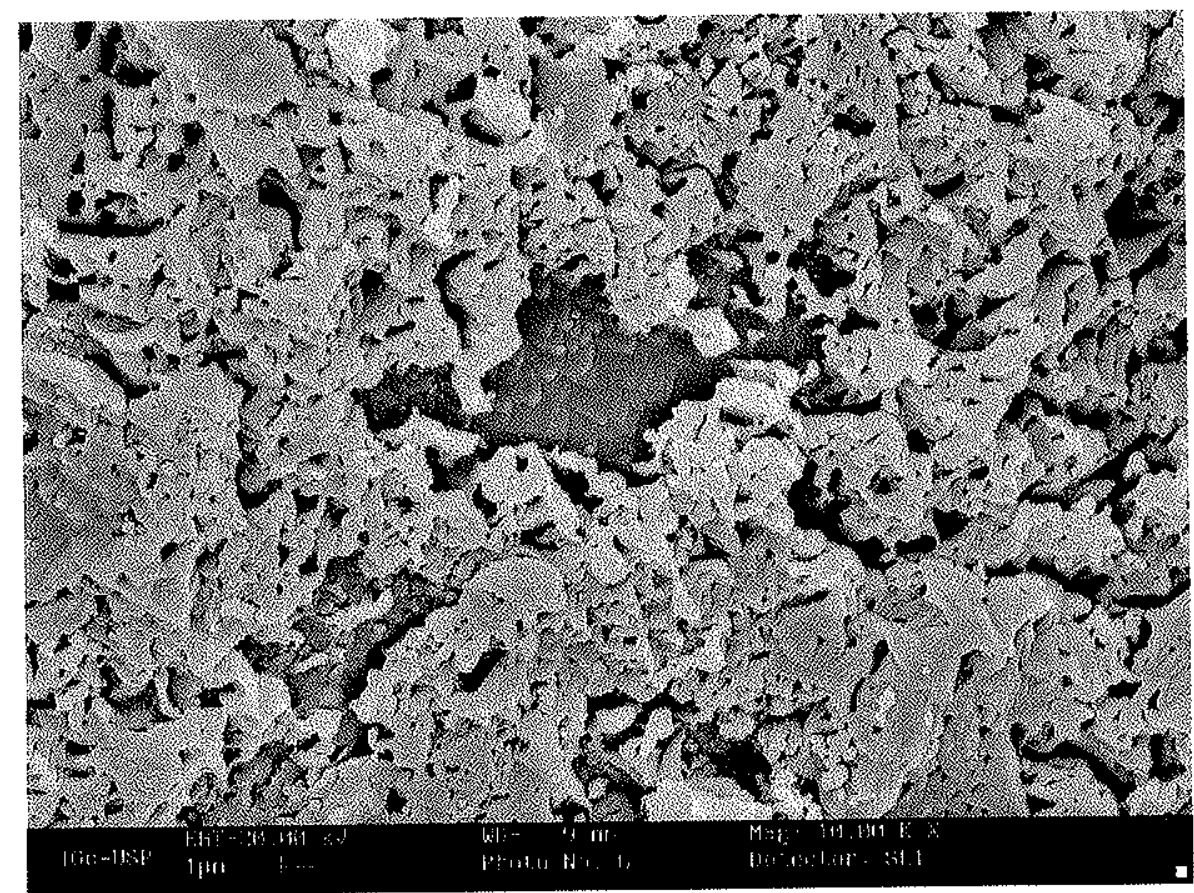

Figura 83 - Cristálitos placoidais, em detalhe, interpretados como caulinita (autigena?) sobre grão de quartzo com feições superficiais de dissolução (amostra MS.12a, topo da Formação Pirambóia, imediatamente abaixo do contato com a Formação Botucatu). Detector: SE1, MAG: $10.00 \mathrm{~K} \mathrm{X}$, (EHT): $20.00 \mathrm{kV}$. 


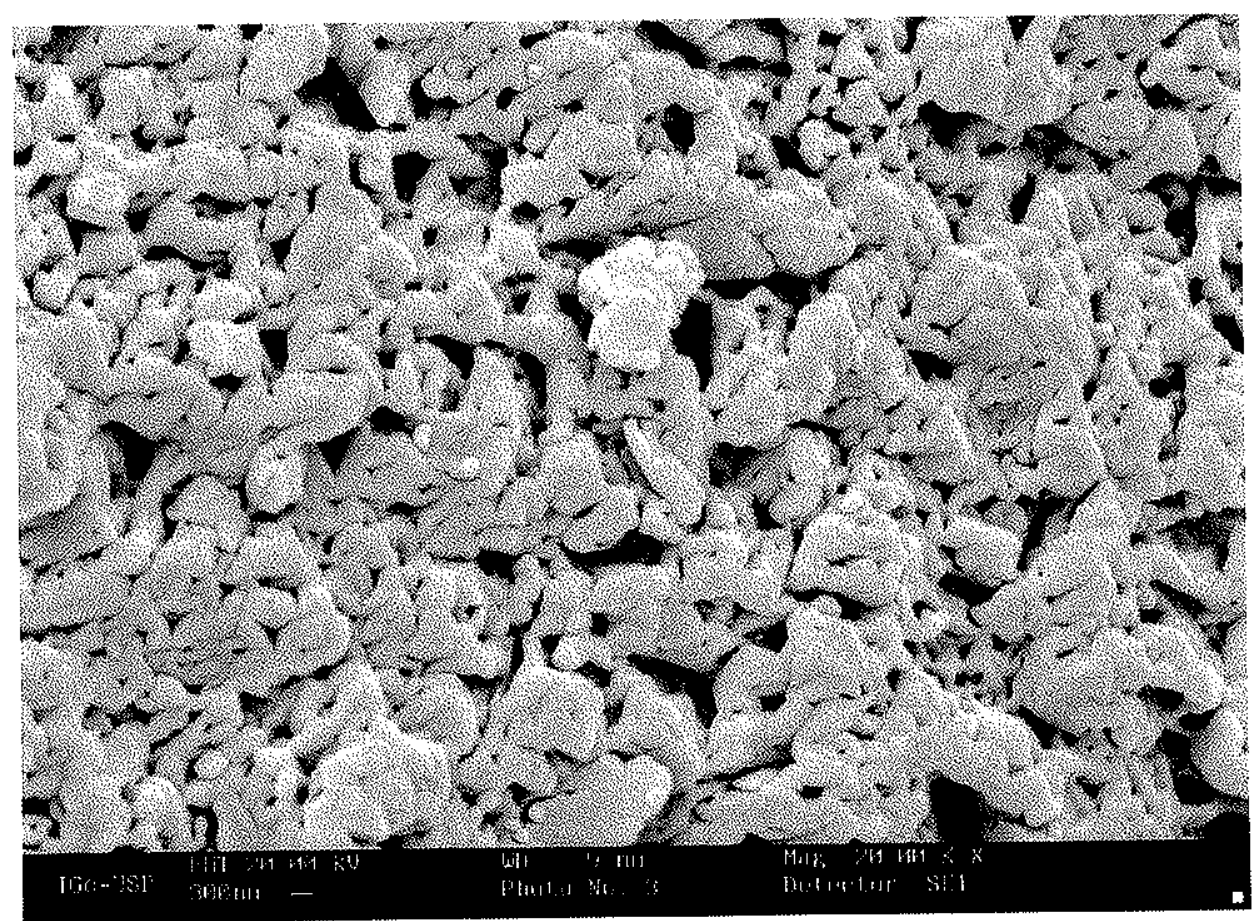

Figura 84 - Detalhe da figura anterior. Notar a presença de argilomineral desmantelado, interpretado como produto de alteração de feldspato. A microanálise ao EED indicou a presença essencial de $\mathrm{Si}, \mathrm{O}$ e Al (amostra MS.12a do topo da Formação Pirambóia). Detector: SE1, MAG: $20.00 \mathrm{~K} \mathrm{X}$, (EHT): $20.00 \mathrm{kV}$.

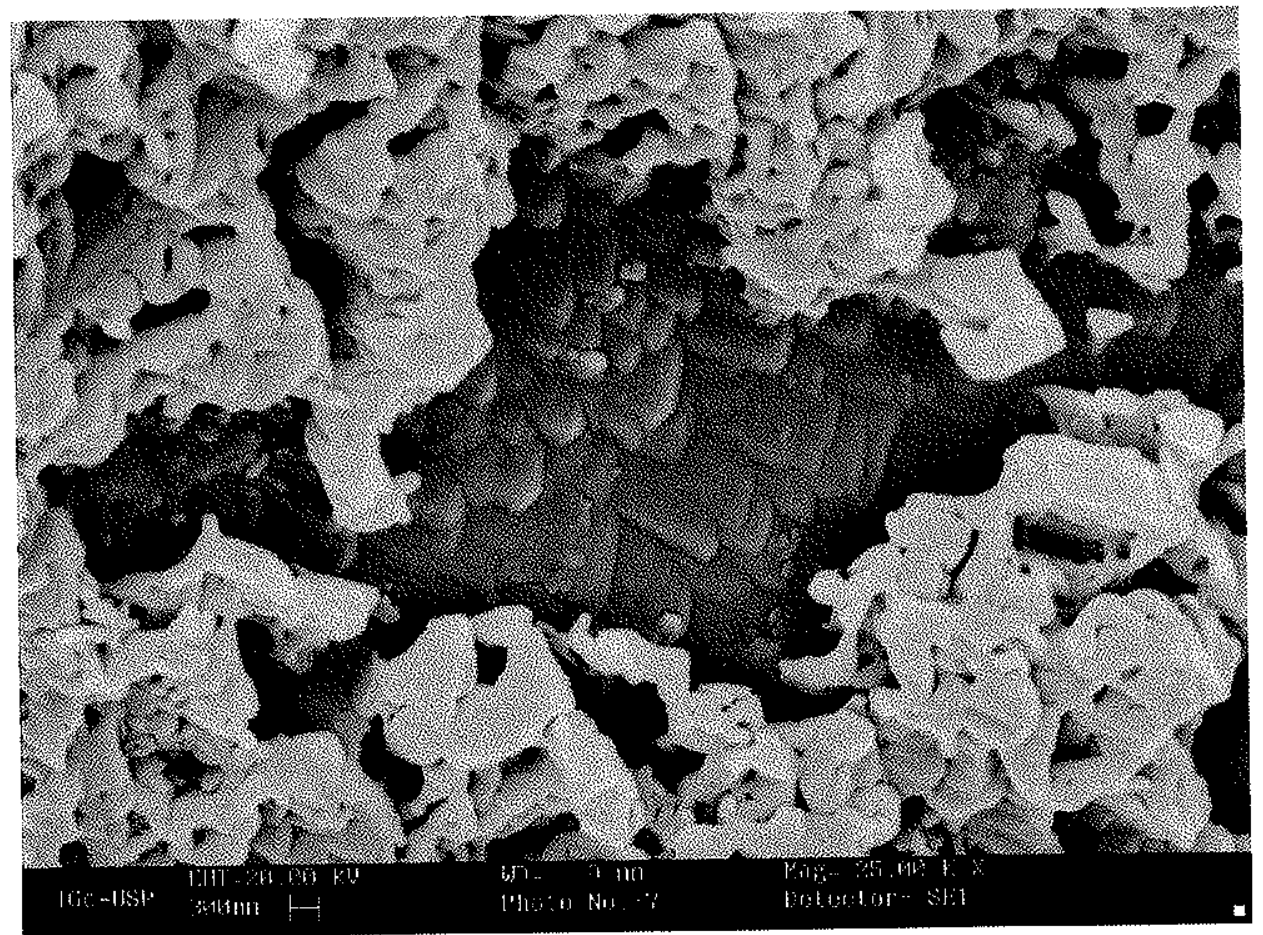

Figura 85 - Detalhe dos cristálitos placoidais sobre grão de quartzo com feições triangulares. A textura superficial do grão é atribuída à dissolução química. Amostra MS.12a, topo do Pirambóia. Detector: SE1, MAG: $25.00 \mathrm{~K} \mathrm{X}$, (EHT): $20.00 \mathrm{kV}$. 
Na amostra IP.01hp, coletada no Formação Botucatu superior, região próxima a Ribeirão Claro, PR, foram encontradas feições poligonizadas acompanhando planos de estratificação cruzada de baixo ângulo de mergulho (Figuras 87 e 88; ver item 3.1.1). A microanálise química e morfológica ao MEV/EED demonstrou a presença extensiva de sílica intersticial meniscóide (Figuras 89 a 91). Face ao modo de ocorrência das feições poligonais interacamadadas à estratificação (Figura 86), esta sílica poderia constituir produto de processo de remobilização química durante a telodiagênese ou ser o registro de evaporitos silicificados.

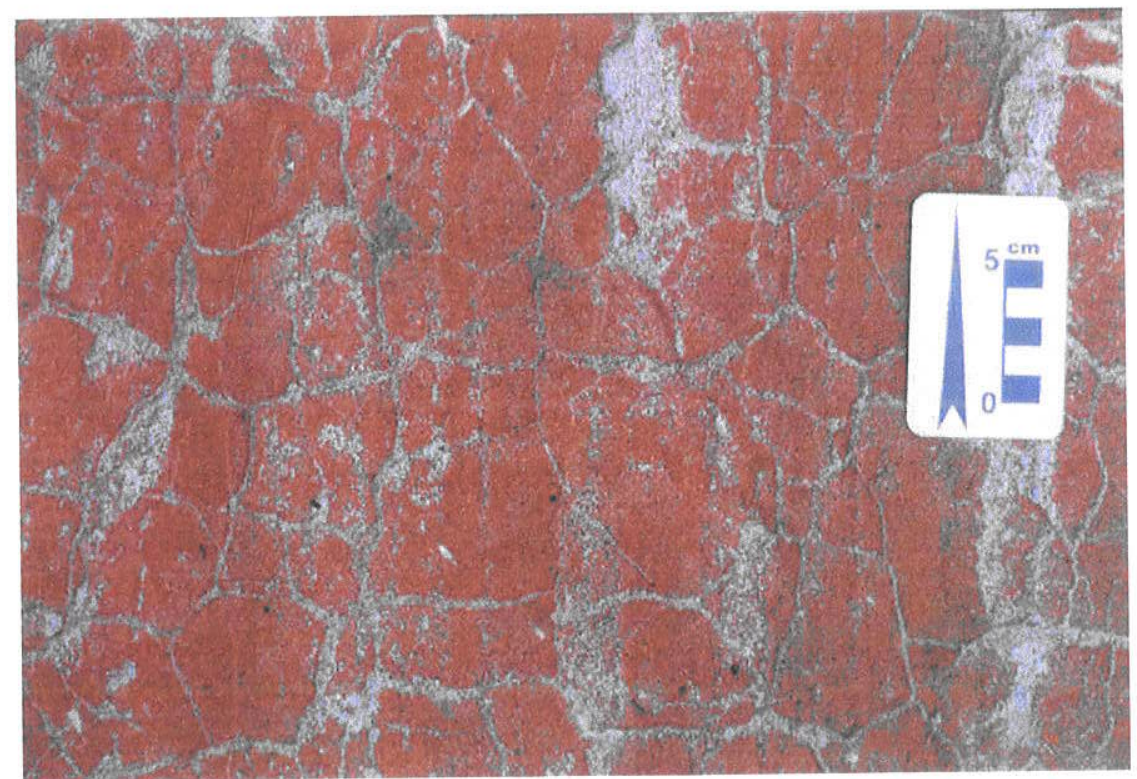

Figura 86 - Feições poligonizadas, sobre superfícies de truncamento de $3^{\mathrm{a}}$ ordem com baixo ângulo de mergulho, da fácies $\mathrm{Acb}$, Formação Botucatu superior. Amostra coletada em lavra de lajes de arenito silicificado em atividade, ponto IP.01, região norte do Paraná, próximo ao município de Ribeirão Claro, PR, quase na divisa com o Estado de São Paulo. 


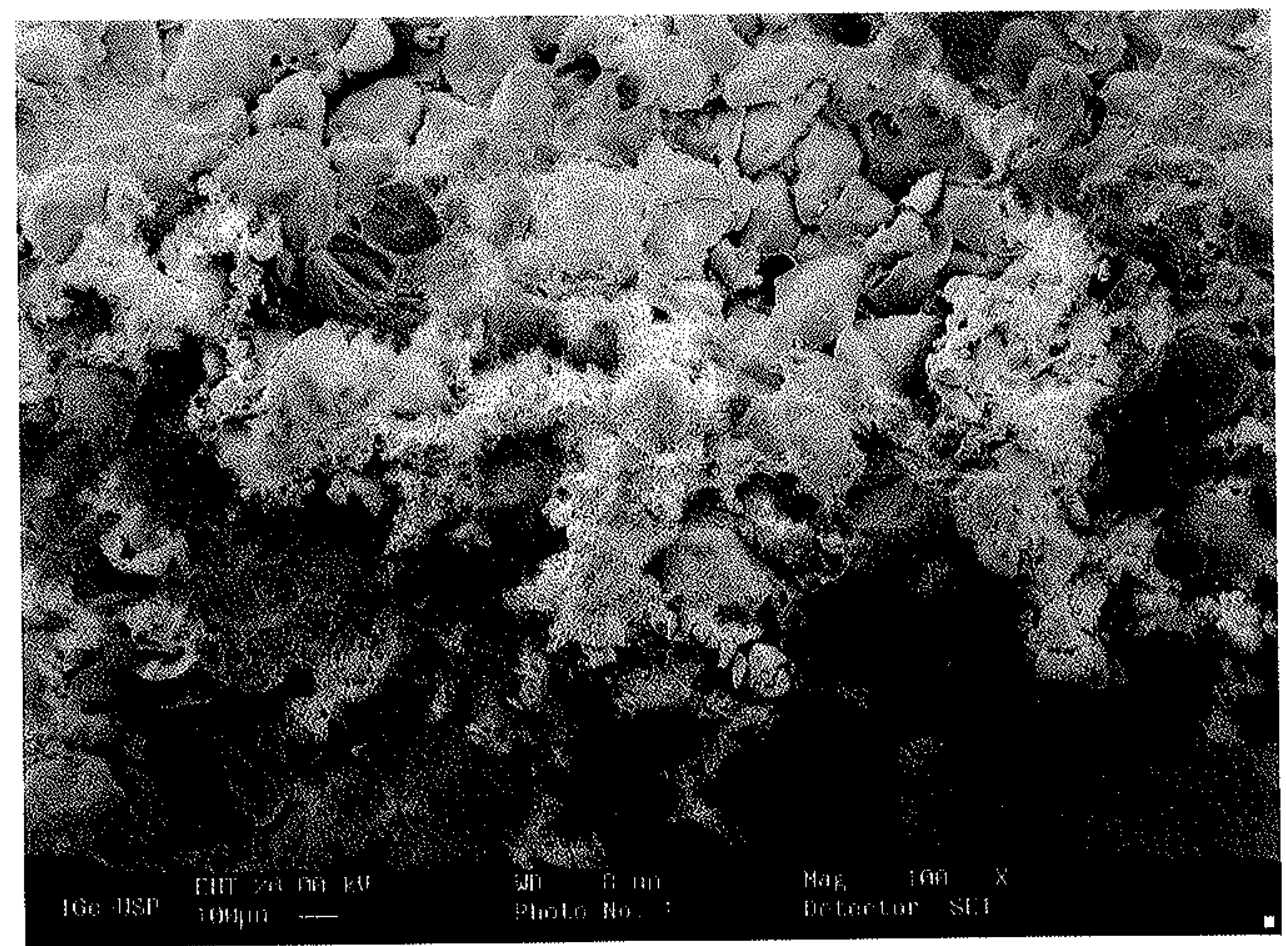

Figura 87 - Visão em pequeno detalhe de cimento impregnante dos grãos do arcabouço. Notar partes esbranquiçadas que definem os traços descritos como feiçōes poligonizadas (amostra IP.01hp, topo do Botucatu na região norte do Paraná). Detector: SE1, MAG: $100 \mathrm{KX}$, (EHT): $20.00 \mathrm{kV}$.

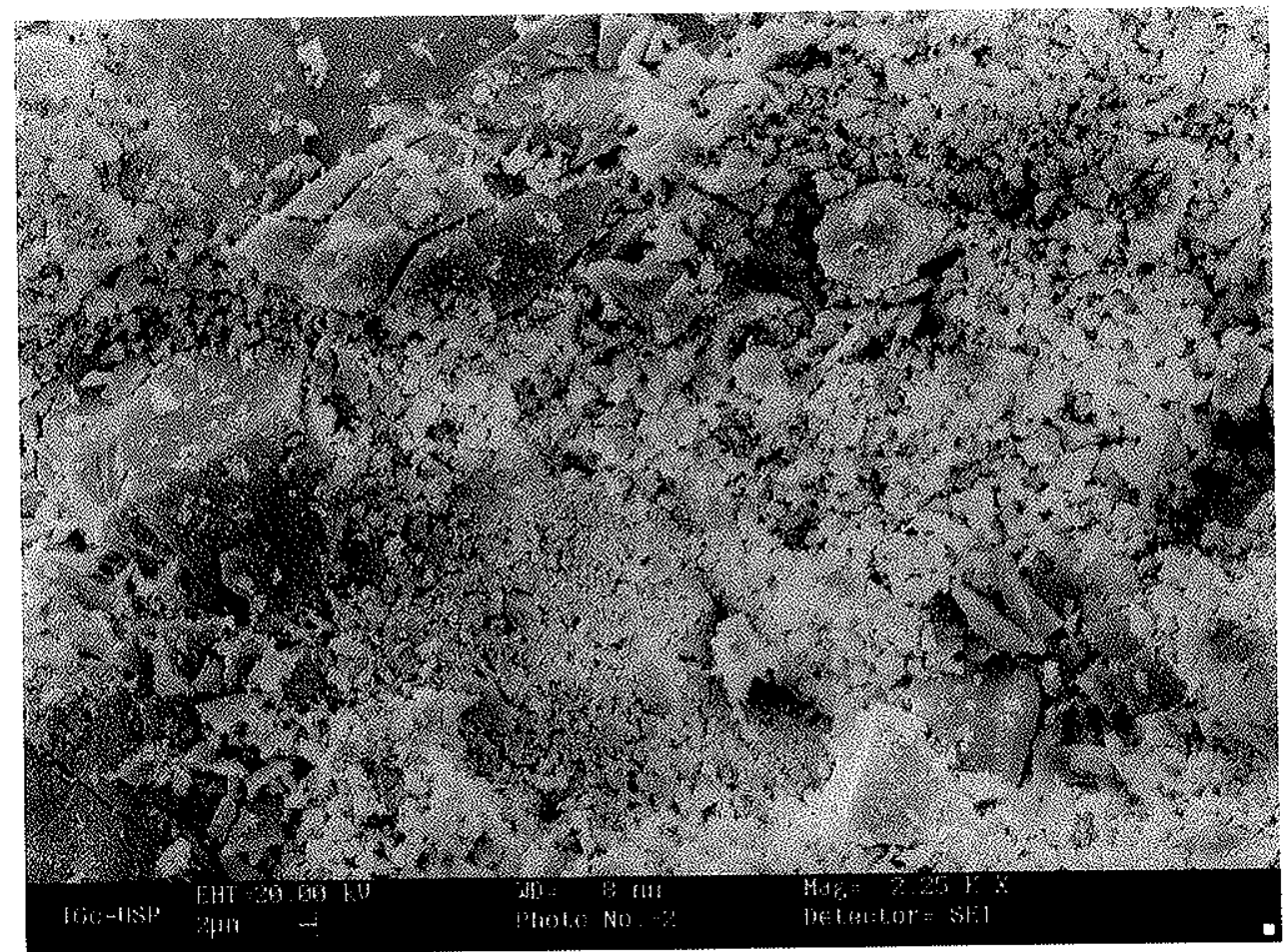

Figura 88 - Detalhe do cimento de silica impregnante dos gräos do arcabouço. As partes brancas correspondem aos traços que definem as feições poligonais em amostra de mão (amostra IP.01hp do topo do Botucatu). Detector: SE1, MAG: 2.25 K X, (EHT): 20.00 kV. 


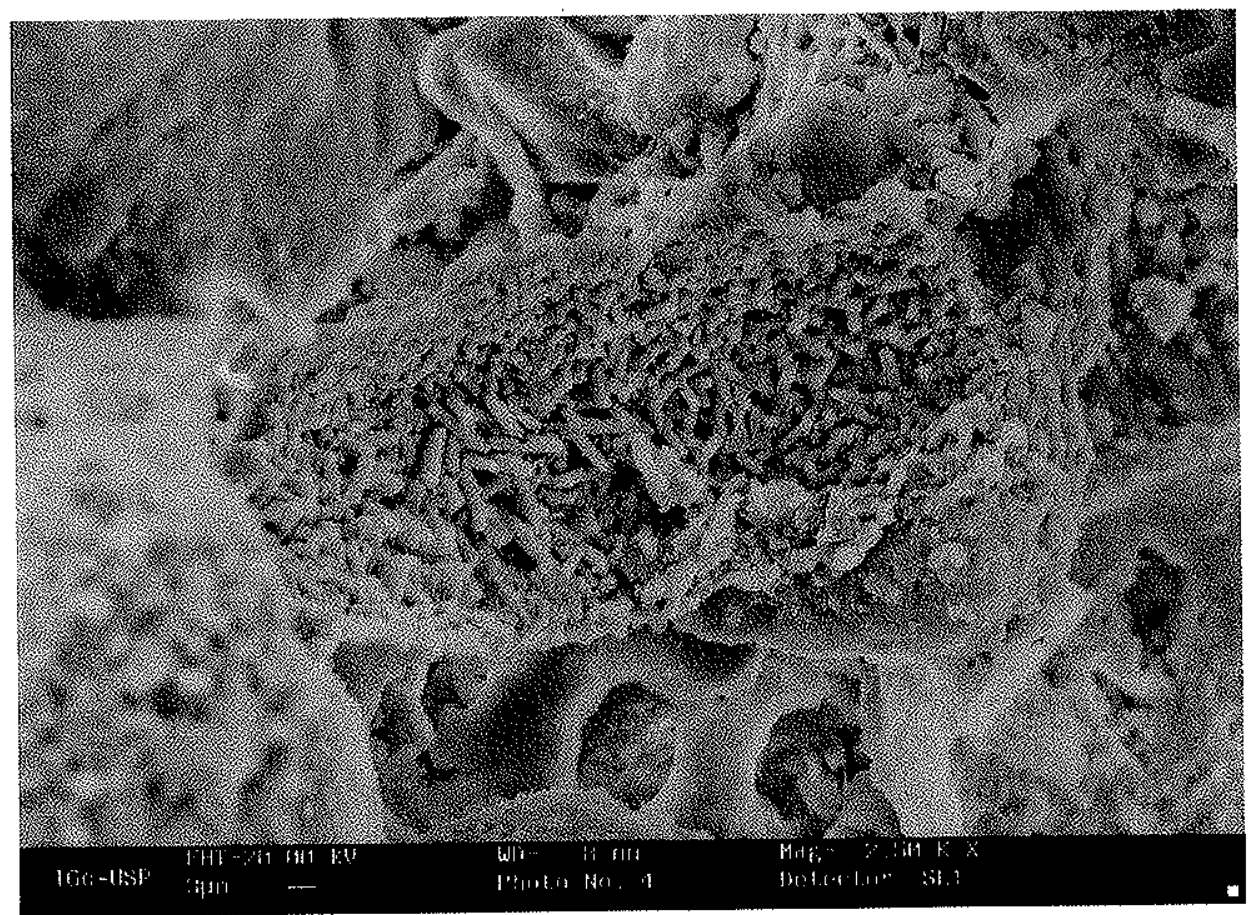

Figura 89 - Detalhe do cimento de silica impregnante dos grãos do arcabouço. Observa-se a presença de duas gerações de remobilização de sílica: uma representada pelos meniscos na porção inferior da imagem e outra pelos cristálitos alongados no centro da imagem (amostra IP.01hp do topo do Botucatu). Detector: SE1, MAG: $2.50 \mathrm{KX}$, (EHT): $20.00 \mathrm{kV}$.

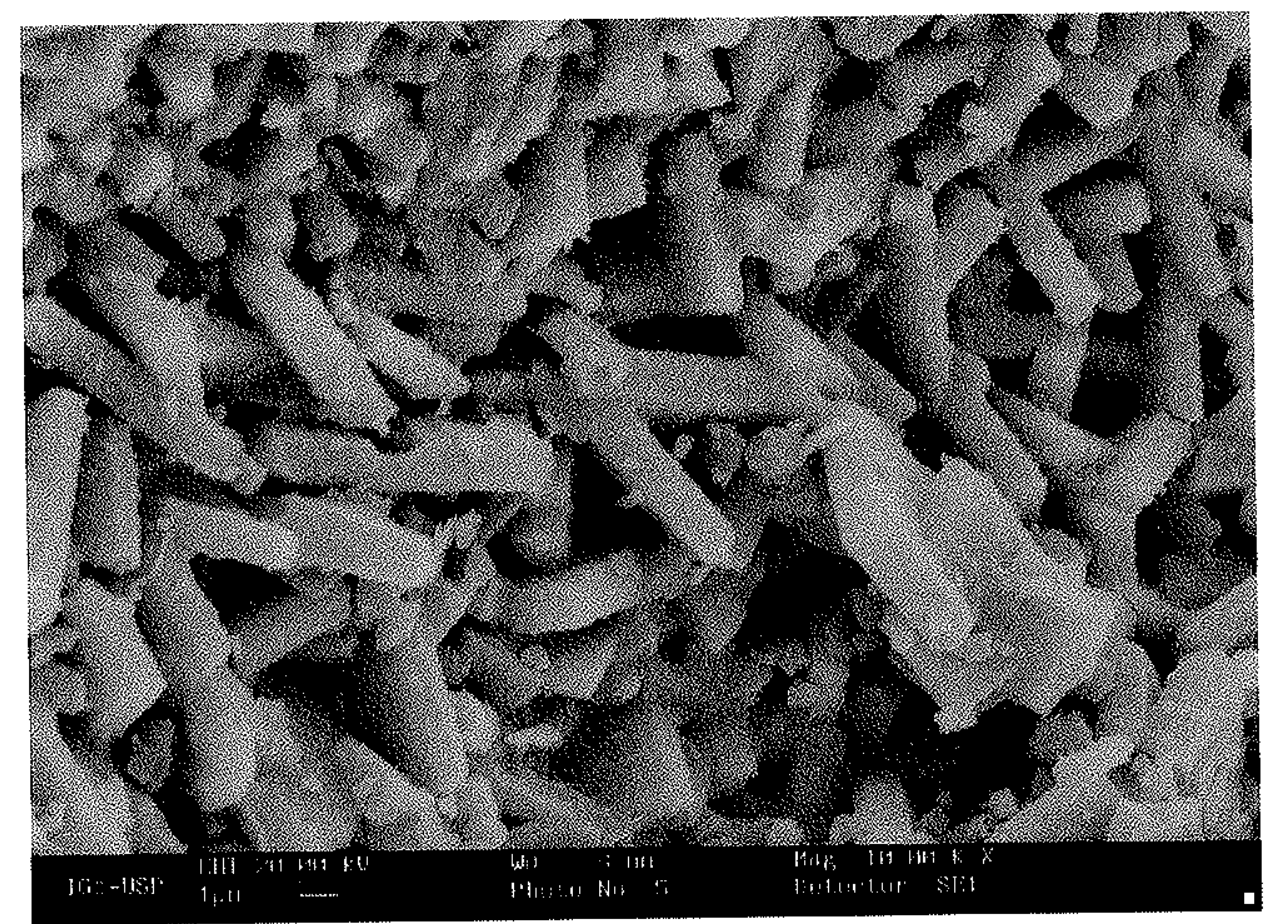

Figura 90 - Maior detalhe do cimento de silica impregnante. Notar forma e disposição caótica dos cristálitos de sílica, similar a pseudomorfos de gipso incipientes descritos em Welton (1984). Amostra IP.01hp, Botucatu superior). Detector: SE1, MAG: $10.00 \mathrm{~K} \mathrm{X}$, (EHT): $20.00 \mathrm{kV}$. 


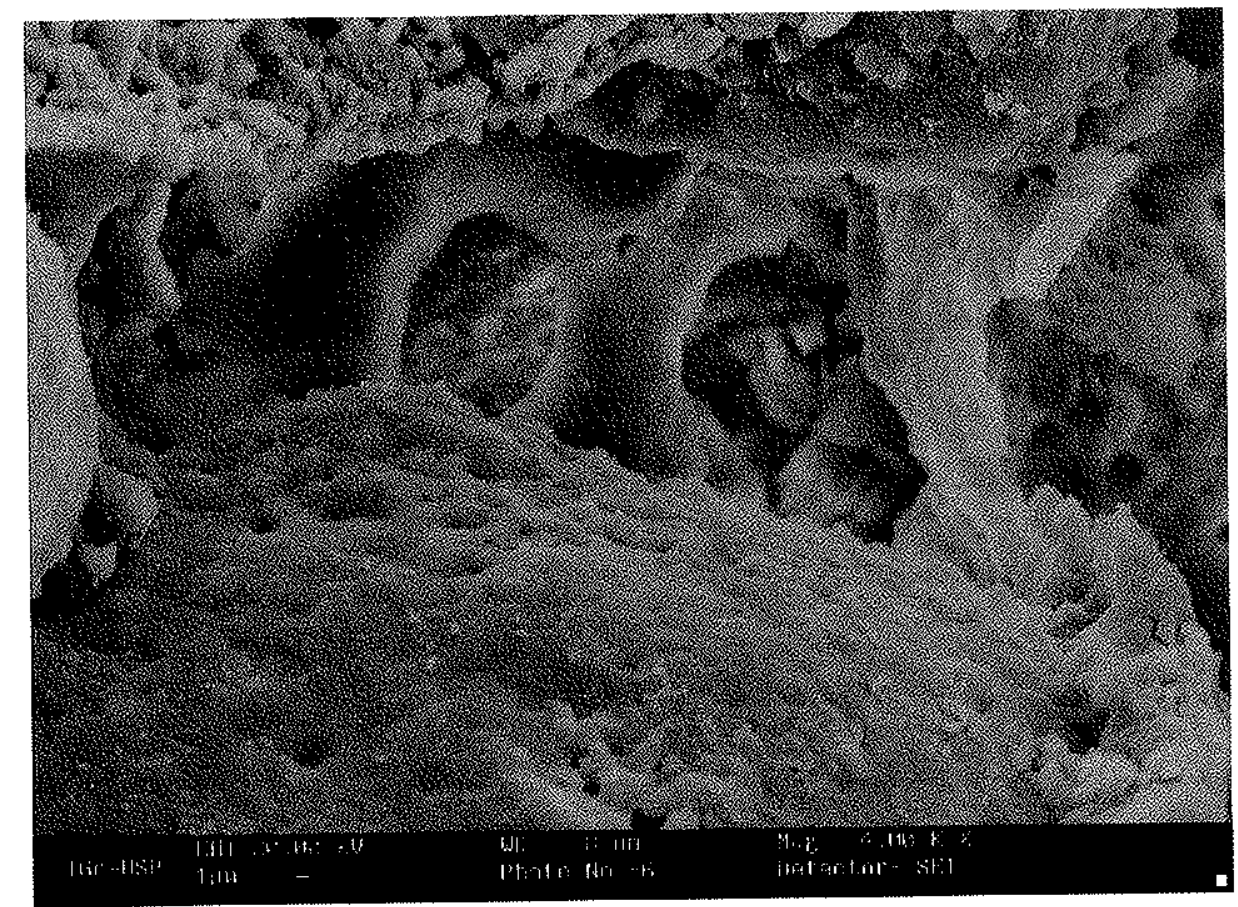

Figura 91 - Aspecto em maior detalhe dos meniscos de sílica da fotomicrografia anterior, atribuídos a processos de remobilização e reprecipitação de $\mathrm{SiO}_{2}$ durante a diagênese. Detector: $\mathrm{SE1}$, MAG: $4.00 \mathrm{KX}$, (EHT): $20.00 \mathrm{kV}$.

Um resultado significativo demonstrado pela análise ao MEV/EED está relacionada ao topo da Formação Pirambóia (amostra GR.11, centro-sul do Paraná, na serra da Esperança). Foram encontrados indícios da presença de paligorskita, argilomineral diagnóstico de condições evaporíticas (Figuras 92 e 93). A análise mais aprofundada desse material ao EED caracterizou a presença de $\mathrm{Mg}, \mathrm{O}, \mathrm{Si}, \mathrm{Al}$ e picos tênues de $\mathrm{Fe}$, cuja composição é plenamente compatível com a de paligorskita. Com base no hábito do mineral, cogitou-se de início, a possibilidade de tratar-se de erionita. Nesse caso, a hipótese mais segura seria a remobilização, por meso-telodiagênese, de zeólitas dos basaltos da Formação Serra Geral. As feições de erionita ilustradas no atlas de microscopia eletrônica de varredura (Welton 1984) são formas fibrosas e alongadas, dispostas como cimento intergranular. Entretanto, a erionita é uma zeólita de sódio, o que não condiz com o resultado de EED obtido ( $\mathrm{Mg}, \mathrm{O}, \mathrm{Si}$ e Al).

A amostra JC.07c (Botucatu) é representada essencialmente por grãos de quartzo subarredondados a arredondados, com presença subordinada de feldspato pouco alterado. Duas gerações de materiais interpretados como de origem diagenética (Figuras 94, 95 e 96) foram observadas: a primeira é representada por esmectita pé-de-couve, cujo crescimento constitui uma película que reveste os grãos de quartzo (Figura 95). A 
segunda geração pode ser relacionada a eventos diagenéticos da alteração e remobilização de elementos químicos provenientes dos feldspatos (Figura 97), definida por caulinita em hábito de acordeon que reveste as esmectitas (Figura 94 e 96).

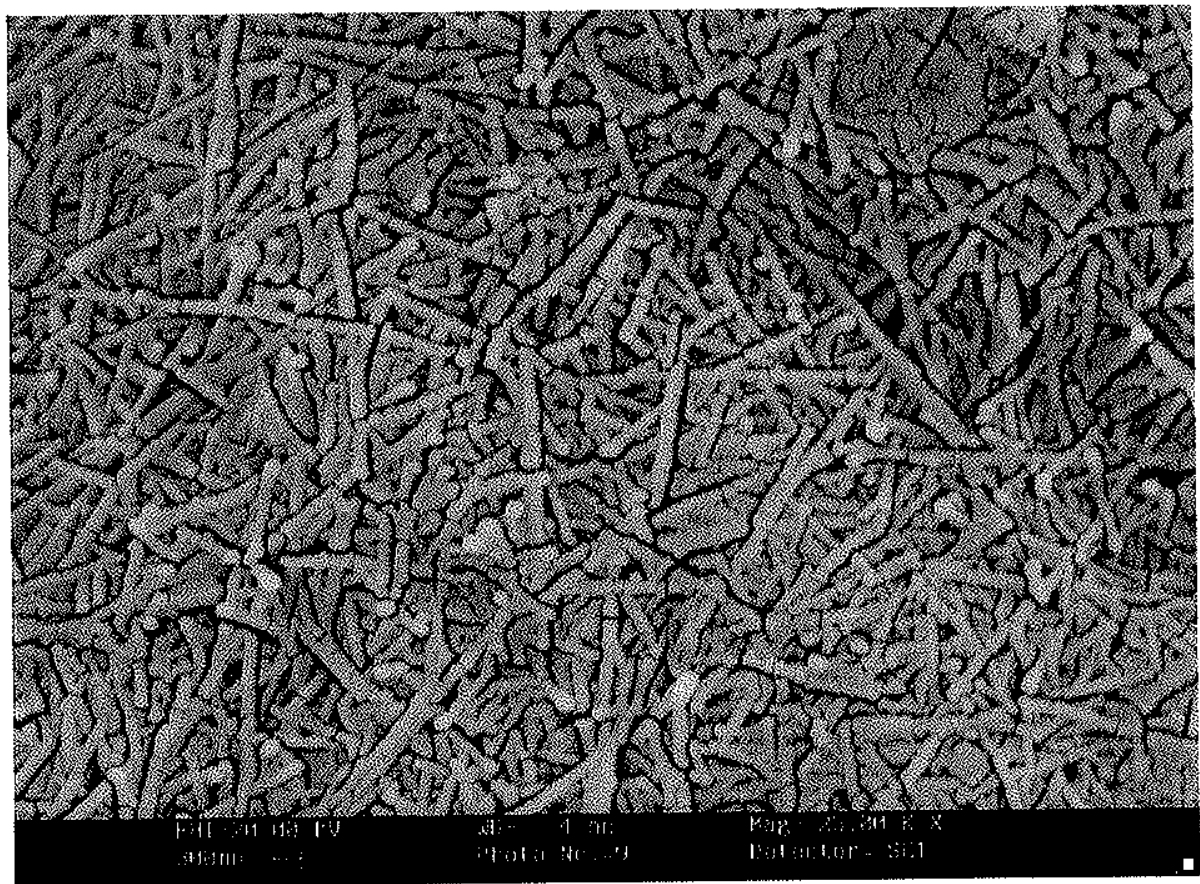

Figura 92 - Aspecto fibro-radiado de argilomineral (provável paligorskita). A análise por EED indicou presença de Al, Mg Si e $\mathrm{O}$ (amostra GR.11c do topo do Pirambóia na região centro-sul do Paraná). Detector: SE1, MAG: $25.00 \mathrm{~K} \mathrm{X}$, (EHT): $20.00 \mathrm{kV}$.

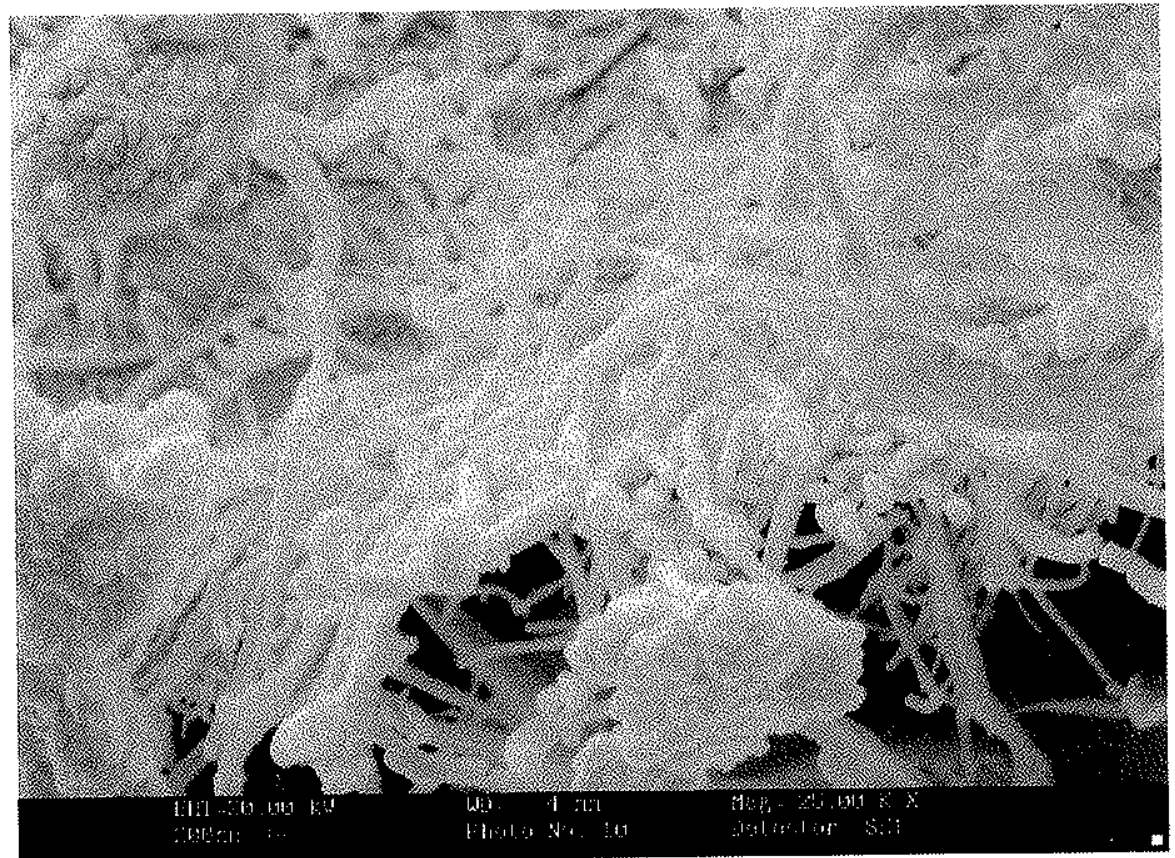

Figura 93 - Outro aspecto das fibras da foto anterior (amostra GR.11c do topo do Pirambóia na região centro-sul do Paraná). Detector: SE1, MAG: $25.00 \mathrm{KX}$, (EHT): $20.00 \mathrm{kV}$. 


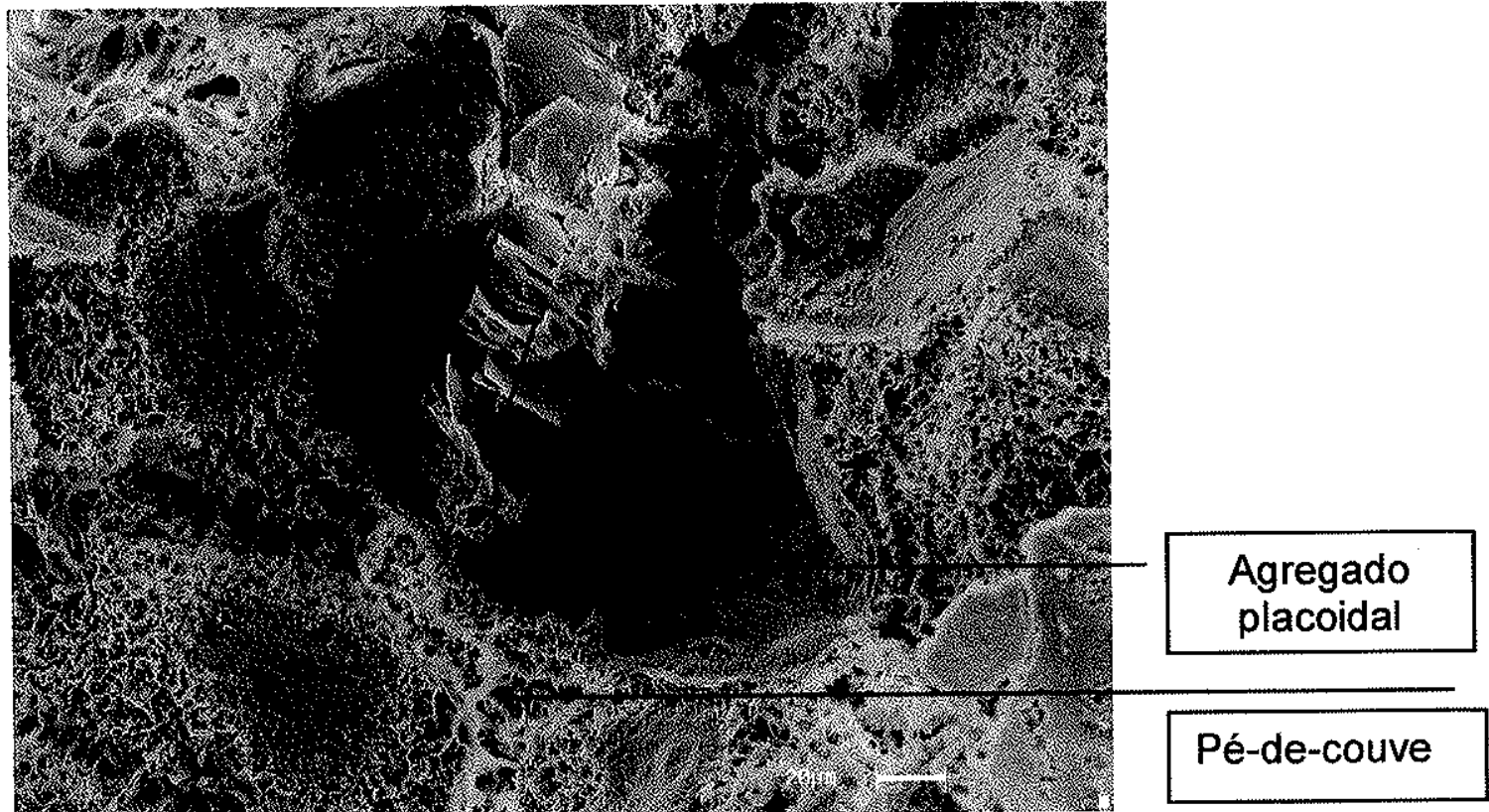

Figura 94 - Mineral interpretado como caulinita autigena, desmantelada por telodiagênese. Resultado de microanálise química ao EED indicou presença essencial de $\mathrm{Si}, \mathrm{O}$, Al e Fe (amostra JC.07c, topo do Botucatu, norte do Paraná). Detector: SE1, MAG: $2.50 \mathrm{~K} \mathrm{X}$, (EHT): $20.00 \mathrm{kV}$.

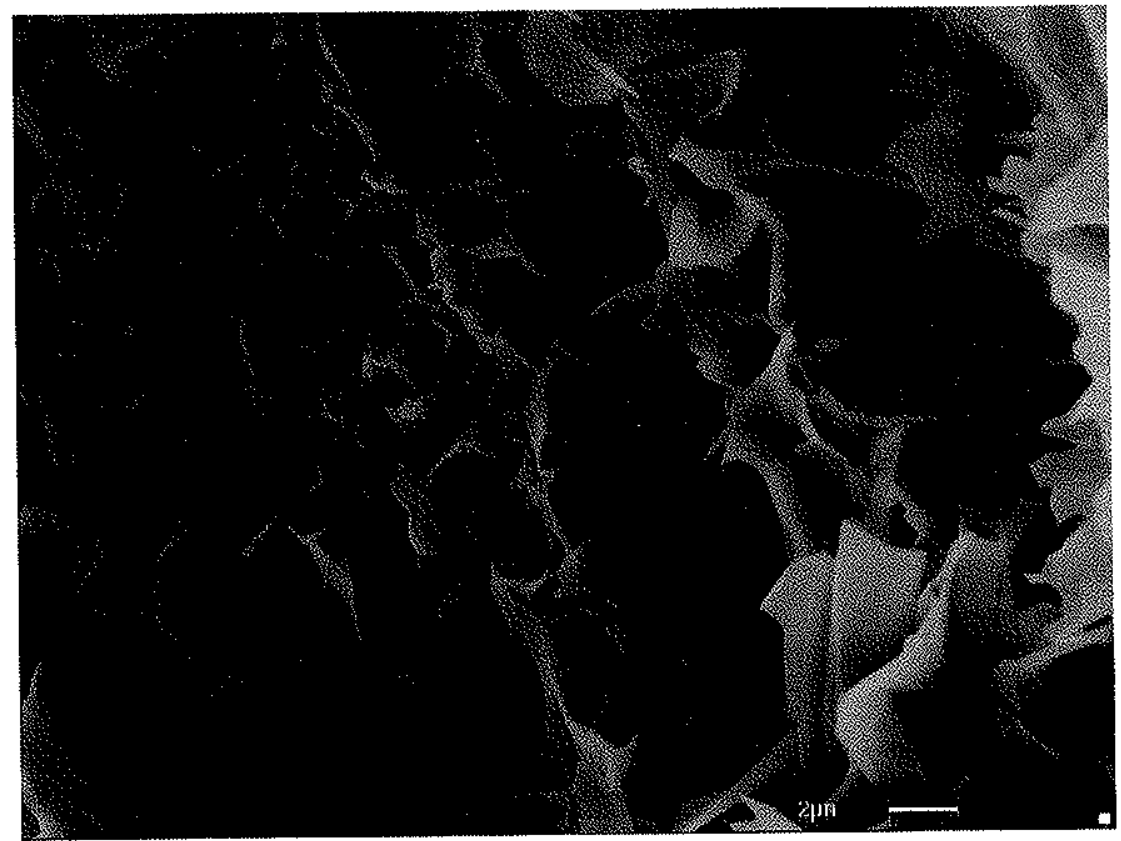

Figura 95 - Aspecto pé-de-couve de provável esmectita. Amostra amostra JC.07c, topo do Botucatu, regiăo norte do Paraná. Detector: SE1, MAG: $2.50 \mathrm{~K} \mathrm{X}$, (EHT): $20.00 \mathrm{kV}$. 


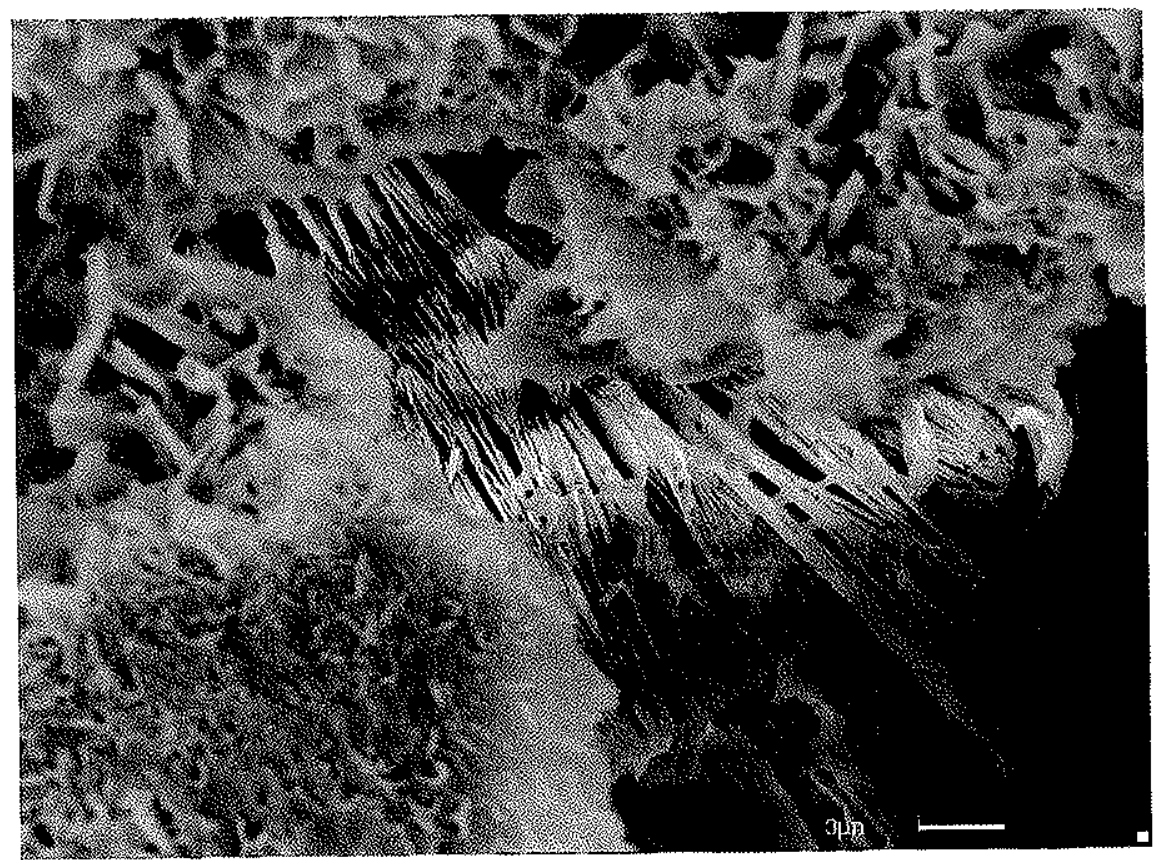

Figura 96 - Agregado placoidal, com aspecto típico de acordeon, de caulinita autígena em amostra do topo do Botucatu na região norte do Paraná (amostra JC.07c). Detector: SE1, MAG: $2.50 \mathrm{~K} \mathrm{X}$, (EHT): $20.00 \mathrm{kV}$.

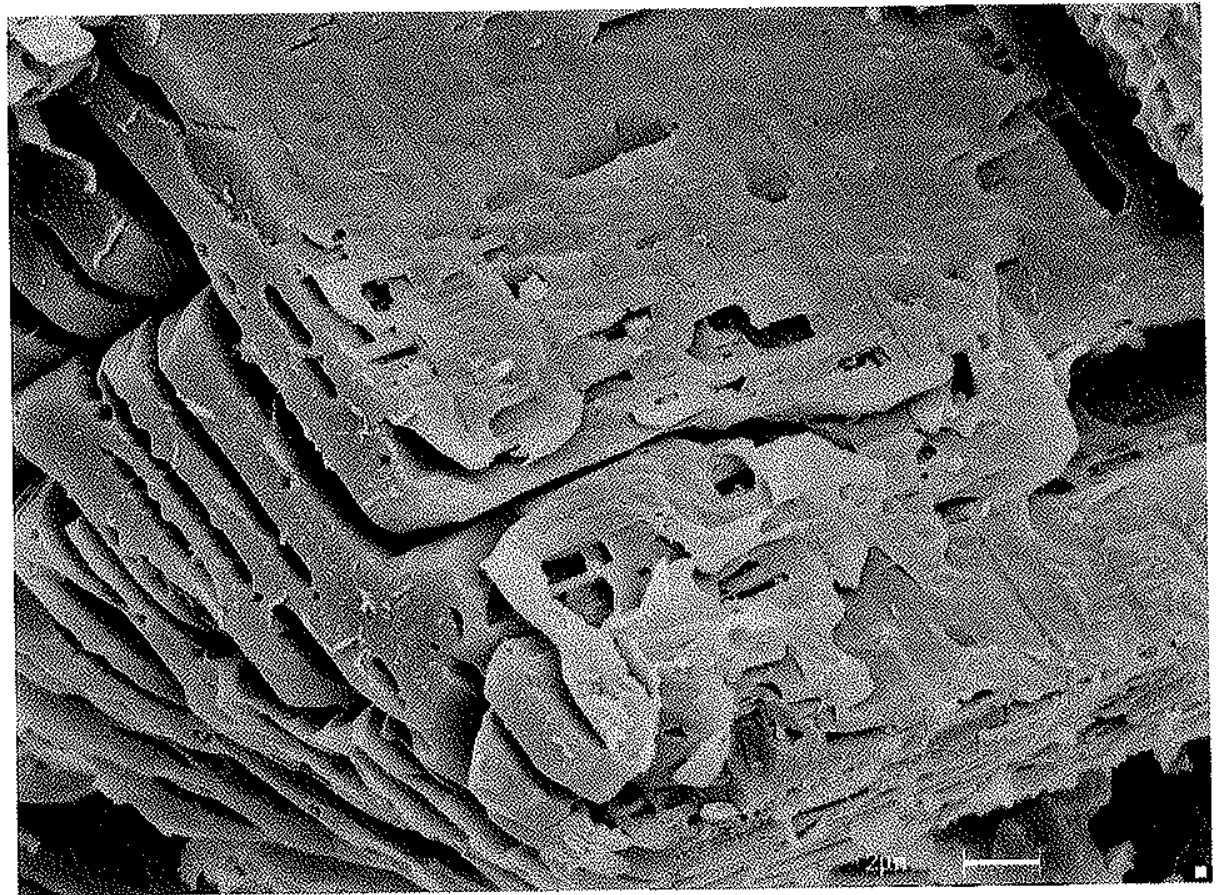

Figura 97 - Microfeiçöes de corrosão química em feldspato. Notar a porosidade intragranular gerada na parte centro-inferior da foto (amostra do topo do Botucatu, coletada no norte do Paraná, ponto JC.07c). Detector: SE1, MAG: $2.50 \mathrm{KX}$, (EHT): $20.00 \mathrm{kV}$. 
Os resultados de MEV-EED relativos aos cimentos de amostras dos sistemas Pirambóia e Botucatu no Estado do Paraná permitem enumerar as seguintes conclusões:

1. Pelo menos três tipos de cimentos filossilicáticos foram encontrados nos arenitos estudados: esmectita, paligorskita e caulinita.

2. Esmectita e caulinita são os cimentos mais freqüentes, podendo ocorrer associados ou não.

3. Quando associados, esmectita e caulinita exibem relações espaciais sugestivas de que a segunda é posterior à primeira.

4. O tamanho e a geometria dos cristálitos de caulinita é variável. Nas amostras mais friáveis, a caulinita, em placas diminutas e mal formadas, constitui o único argilomineral presente. Nos casos de arenitos menos alterados, caulinita bem formada e esmectita ocorrem juntas. Quando presente, a paligorskita ocorre aparentemente como único cimento da rocha.

5. Caulinita (mal formada) é o único argilomineral detectado ao MEV em presença de cimento de quartzo.

6. A esmectita encontrada nos arenitos do sistema eólico Botucatu apresenta-se localmente enriquecida em $\mathrm{Fe}$ e $\mathrm{K}$, em comparação com os teores destes elementos nos arenitos Pirambóia.

7. Existe suspeita quanto à presença de sílica pseudomorfa de gipso ao longo dos traços de polígonos em superfícies de baixo ângulo do arenito Botucatu. Caso seja confirmada, esta hipótese traria subsídios para interpretar condições eogenéticas evaporíticas em superficies interdunares secas. Esta seria portanto a primeira ocorrência de evidências de sal naquela unidade.

8. O argilomineral esbranquiçado encontrado no contato entre os arenitos Pirambóia e Botucatu na região de serra do Cadeado, centro-norte do Paraná, próximo ao município de Mauá da Serra, PR, é formado por caulinita com sinais de intensa lixiviação, possivelmente telodiagenética. Isto permite interpretar a existência de uma zona de circulação preferencial de percolação de água, ao longo do contato. Poderia representar uma extensa superfície de descontinuidade física, talvez com atributos de paraconformidade. 


\subsection{Apresentação das seções geológicas}

A partir da realização das jornadas de campo, foram confeccionadas seções geológico-estratigráficas tendo como base cartográfica as folhas topográficas do IBGE e do Serviço Geográfico do Ministério do Exército.

Após a definição dos critérios para diferenciar as formações Pirambóia e Botucatu, procedeu-se a confeç̧ão das seções, lançando-se mão das descrições de campo e dados parciais de laboratório, com o apoio de mapas geológicos publicados e de algumas fotos aéreas.

A falta de representatividade das estruturas tectônicas, somadas à escassez de medidas confiáveis de altitudes de alguns pontos descritos, de obtenção de medidas de acamamento e da dificuldade de correlacioná-las a feições tecto-sedimentares, foram algumas das dificuldades operacionais relacionadas à confecção das seçöes. Soma-se a isso o baixo valor dos ângulos de acamamento, em torno de $2^{\circ}$ a $3^{\circ}$, associadas a enxames de diques de rocha ígnea, o que torna questionáveis as medidas de mergulho obtidas. Cabe ressaltar, ainda, as dificuldades quanto à identificação dos contatos nos escassos afloramentos, quase sempre encobertos por vegetação e a freqüente presença de óxido de ferro e bioturbaçōes, que obliteram parte das feições primárias.

A geometria do contato basal do Pirambóia pôde ser definida em alguns pontos: ao norte do estado, regiōes de Jacarezinho e Mauá da Serra, ou no centro-sul, na seção de Guarapuava. Caracteriza-se pelo caráter transicional (gradual), como aventado por inúmeros autores (Almeida et al. 1984 e Riccomini 1995 por exemplo). As espessuras dos sistemas são relativamente constantes, quase sempre em torno de $100 \mathrm{~m}$ no Pirambóia e em torno de $50 \mathrm{~m}$ no Botucatu. Entretanto, próximo a divisa entre São Paulo e Paraná, esta característica muda, sendo o Botucatu mais espesso.

O caráter abrupto do contato entre os arenitos Pirambóia e Botucatu é nítido, localmente ressaltado pela presença de seixos e grânulos ou argilominerais esbranquiçados. Além destas características, degraus irregulares com poucos centímetros de espessura, podem ser encontrados junto no contato. Estas irregularidades apresentam-se associadas a certa gradação de cores, entre cinza claro e tons de vermelho, possivelmente de origem secundária, mas que podem estar refletindo alguma estrutura primária. A visualização de falhas e fraturas em arenito não foi tarefa fácil, embora fossem perfeitamente visíveis no contato entre as unidades na serra do Cadeado, centro-norte do estado, entre os pontos MS.05 e MS.08. Trata-se ai de falhas normais 
com blocos altos e baixos do tipo horst/graben, com rejeito decimétrico. Junto ao plano encontrou-se foliação salientada por resquícios de argilominerais e suave alinhamento de grãos de quartzo. A construção das seçōes 02 a 09 , anexas, sugere que deslocamentos seriam predominantemente do tipo normal e de pequeno rejeito. 


\section{CONCLUSÕES}

Nas conclusões que se seguem, procurou-se também apontar guias para investigações e questionamentos futuros.

1. A dificuldade prática de distinção entre os afloramentos das formações Pirambóia e Botucatu não justifica seu agrupamento em uma só unidade litoestratigráfica. Existem critérios litológicos e de posição estratigráfica para separação e mapeamento das duas unidades, mesmo em regiões onde as formações têm sido tradicionalmente agrupadas, como no Paraná e no norte de Santa Catarina.

2. Na definição original da Formação Pirambóia, a fácies com contribuição rudácea aqui referida pela sigla $\mathrm{ACg}$, ou pelo menos parte de suas ocorrências, foi incluida na porção basal da Formação Botucatu (Soares 1973, 1975, 1986, 1996). Do ponto de vista puramente litoestratigráfico, esta fácies poderia ser inserida tanto na base da Formação Botucatu como no topo da Formação Pirambóia. A decisão entre estas duas alternativas pressupõe o estudo da possibilidade de haver discordância acima ou abaixo do intervalo de recorrência desta fácies, o que, por sua vez, implica a necessidade de detalhar o seu padrão de associação de fácies.

3. Os resultados de análise de fácies obtidos neste projeto indicam que a fácies $\mathrm{ACg}$ ocorre acima e interdigitada com várias fácies de dunas e planícies interdunares, comuns desde a passagem entre os Grupos Passa Dois e São Bento. Acima dela, a associação de fácies muda drasticamente e torna-se monótona, sem fácies de planícies interdunares bem individualizadas. O intervalo vertical de recorrência da fácies $\mathrm{ACg}$ atinge mais de $50 \mathrm{~m}$ de espessura em algumas regiões, equivalendo aproximadamente à metade superior da fatia estratigráfica compreendida entre o seu topo e a passagem Passa Dois / São Bento.

4. Seguindo o raciocínio das três conclusões anteriores, optou-se aqui por incluir a fácies $\mathrm{ACg}$ na sedimentação Pirambóia. Sua presença seria o principal critério geológico para caracterizar a parte superior desta unidade. Esta opção contraria a acepção do termo Formação Pirambóia, quando do batismo da unidade litoestratigráfica. Torna-se conveniente portanto evitar $o$ enfoque $e$ a linguagem litoestratigráficas, em troca de uma abordagem voltada para a evolução de sistemas deposicionais.

5. Do ponto de vista da análise de associações faciológicas e sistemas deposicionais, os arenitos em estudo guardam o registro de um sistema eólico úmido (sensu 
Kocurek \& Havhlom 1993), o sistema Pirambóia, sucedido via discordância por um sistema eólico seco, o sistema Botucatu. Esta interpretação corresponde à identificação de quatro associações de fácies neste primeiro sistema, denominadas de $A, B, C$ e D, com posicionamento estratigráfico distinto. Da base para o topo, as associações interpretadas correspondem a: A - lençóis de areia em planície de maré mista; B - campo de dunas incipiente, costeiro, com alguma contribuição fluvial; C - planície aluvial com rios entrelaçados e D - campo de dunas essencialmente seco, com depressões interdunares secas.

6. A sucessão de fácies representa a instalação gradual de um sistema deposicional eólico úmido, marcado, em seu inicio pela interação costeira, cujo fetch praial seria potencialmente responsável por constante retrabalhamento de areias incoesas, até o desfecho do sistema, representado por interação flúvio-eólica ao topo, limitado por descontinuidade marcante na passagem de sua porção úmida (associações $A$, B, C do sistema Pirambóia) e seca (associação D do sistema Botucatu).

7. Os achados de icnogênero Muensteria contribuem para mais algumas considerações sobre o sistema Pirambóia. Aceita a interpretação paleobiogeográfica deste icnogênero, realizadas na Formação Sanga do Cabral no Rio Grande do Sul (Netto 2001), a ocorrência deste tipo de icnofóssil seria considerada tipicamente continental, porém necessariamente com contribuição de água. Estes icnogênero têm sido relacionado a depósitos de lâmina d'água delgada, em ambiente pouco estressante, o que permitiria o desenvolvimento dos organismos. O grande número, mais que 200, de tubos de Muensteria registrados no sistema Pirambóia, reforçaria a interpretação da contribuição de água na deposição do sistema eólico Pirambóia.

8. A única supersuperfície seguramente reconhecida no sistema eólico Botucatu é o seu topo, o qual representa a interrupção quase total do efluxo eólico do sistema, devido ao recobrimento da superfície deposicional arenosa pelos derrames Serra Geral.

9. Em relação ao sistema eólico úmido Pirambóia, a distribuição geográfica das fácies, o contato interdigitado com os depósitos de maré do Mar Passa Dois e com - Delta Morro Pelado e os rumos de paleoventos oriundos da paleocosta no Paraná convergem para a interpretação de um contexto de dunas costeiras, pelo menos no início da sedimentação.

10. De acordo com os dados de azimutes de paleoventos, o sistema Pirambóia nos estados de São Paulo e Paraná contaria com dois influxos eólicos convergentes, 
um continental, com fonte a NE, e outro possivelmente costeiro, com fonte a SW e SSW. O efluxo destes dois vetores de transporte eólico seria determinado pela perda de competência em função da distância à fonte e pela existência de paleoaltos transversais, possivelmente relacionados em posição e/ou orientação ao Arco de Ponta Grossa.

11. Durante a vigência do sistema eólico seco Botucatu, a redução das áreas inundadas teria favorecido o aumento do influxo, voltado em toda a área estudada para sul. As primeiras manifestações vulcânicas na parte oeste do Arco de Ponta Grossa teriam afetado o influxo no Paraná e determinado o padrão polimodal que caracteriza o topo da Formação Botucatu nesse estado. Entretanto, o desenvolvimento de draas estrelados constitui outro fator a ser considerado para o padrão polimodal observado no topo do sistema Botucatu.

12. De modo geral, as direções de ventos predominantes na sedimentação dos sistemas eólicos Pirambóia e Botucatu refletem o controle da morfologia da bacia, alongada segundo SSW-NNE. Direçōes anômalas em relação a esse padrão geral ou zonas de convergência e divergência de rumos estariam ligadas à borda da bacia ou à existência de arcos internos no âmbito regional.

13. Os resultados de granulometria caracterizam granocrescência ascendente nítida no sistema Pirambóia e granodecrescência sutil no sistema Botucatu. Os arenitos grossos $(\mathrm{ACg})$ da parte superior do registro do sistema Pirambóia constituem a fácies de padrão granulométrico mais diagnóstico, caracterizado por diâmetro médio mais grosso que $1,8 \varnothing$, relação fino/grosso menor que 0,15 e classe modal em areia média e/ou grossa.

14. A fácies $\mathrm{ACg}$ seria o registro da existência de rios entrelaçados, distais de leques aluviais, formados no contexto de recrudescimento tectônico que determinou o desfecho do sistema eólico Pirambóia.

15. No contexto tectônico acima, o topo dos depósitos do sistema Pirambóia foi submetido à erosão, antes da instalação do sistema Botucatu. A discordância resultante (contato Pirambóia-Botucatu) materializa a deposição de areias eólicas finas sobre arenitos médios a grossos com cascalho. Dada a impossibilidade de erosão pronunciada dos arenitos Pirambóia pelo agente deposicional do sistema Botucatu (vento), o caráter discordante do contato não pode ser facilmente evidenciado no campo, mas pode ser sugerido em estudos petrográficos e mineralógicos mais minuciosos. 
16. Os resultados de petrografia e mineralogia de pesados apontam para diferenças consideráveis entre os arenitos dos dois sistemas. $\mathrm{O}$ sistema Botucatu distingue-se do Pirambóia pelos teores de pesados localmente elevados, pelos maiores índices de maturidade mineralógica (ZTR e razão de quantidade quartzo/feldspato), pelo contexto tectônico menos efetivo (maior razão de tamanho quartzo/feldspato) e pelo maior volume médio de cimentação. A cimentação silicosa e/ou ferruginosa precoce dos arenitos Botucatu seria responsável pela maior proteção dos minerais à dissolução, daí as texturas de corrosão pós-deposicional aparentarem menor desenvolvimento que nos arenitos Pirambóia.

17. Esmectita é o argilomineral mais comum como cimento de arenitos pouco alterados, em ambos os sistemas. Se eodiagenética, ela pode indicar escassez de água em circulação no ambiente de sedimentação e soterramento.

18. Caulinita associa-se às vezes à esmectita, podendo ser interpretada nesses casos como seu produto de alteração. É encontrada com freqüência, impregnando os grãos do arcabouço ou, quando desmantelada, preenchendo os poros.

19. Haveria condições de canibalismo durante a deposição da Formação Pirambóia, cuja indicação é relacionada a estruturas do tipo armoured balls (bolas encouraçadas).

20. Condições evaporíticas, indicativas de paleoclima árido a semi-árido, devem ter persistido desde o final da sedimentação do Mar Passa Dois até o desfecho do sistema Pirambóia. Em relação ao Mar Passa Dois, as evidências de ambiente evaporítico citadas na bibliografia incluem oóides fibro-radiados com elevado teor de Sr (Coimbra \& Giannini 1989) e niveis de gipsita nodular silicificada a quartzina. Outros indícios de sedimentação evaporítica, encontrados no topo da Formação Terezina nos trabalhos de campo deste projeto, incluem sílica pseudomorfa de cristais centimétricos de gipso com hábito em espada, camadas de material silicificado gretado (Camada Porangaba de Matos 1995, em domínio paulista) e dobras enterolíticas e teepes embrionários na Formação Terezina, na região de Jacarezinho, PR e Santo Antônio da Platina, PR. Em relação ao sistema Pirambóia, destaca-se o registro de paligorskita, como cimento de arenitos da fácies $\mathrm{ACg}$, próximo ao contato com os arenitos finos do sistema Botucatu. Já neste último, destacam-se: observação, em lâmina delgada, de cimento de quartzina e pseudomorfos tabuliformes intercrescidos de gipso, encontrados na análise ao MEV/EED da amostra IP.01hp (sistema Botucatu superior) indicativos de alta taxa de evaporação. 
21. Admitido um paleoclima árido a semi-árido para o sistema Pirambóia, o caráter úmido deste sistema eólico (sensu Kocurek \& Havholm 1993) deve ser necessariamente atribuído à proximidade entre lençol freático e superfície deposicional, o que pode ser explicado pelo contexto costeiro proximal.

22.0 registro tectônico a ser observado em afloramento sugere falhas preponderantemente distensivas, com rejeitos decimétricos a métricos, com blocos rebatidos do tipo horst/graben exibindo rejeitos decimétricos a métricos. 


\section{REFERÊNCIAS BIBLIOGRÁFICAS}

ALMEIDA, F.F.M. 1950. Uma faunula de crustáceos bivalvos do arenito Botucatú no Estado de São Paulo. DNPM, Divisão de Geologia e Mineralogia. Boletim 134. Rio de Janeiro.

ALMEIDA, F.F.M. 1953. Botucatu, a triassic desert of South America. In: INTERNATIONAL GEOLOGICAL CONGRESS, 19, Alger. Conmpte Rendus... Alger, IGS, Séction VII, p. 9-24.

ALMEIDA, F.F.M. \& BARBOSA, O. 1953. Geologia das quadrículas de Piracicaba e Rio Claro, Estado de São Paulo, Brasil. Bol. DNPM / DGM, 143:96p.

ANDERTON, R. 1985. Clastic facies models and facies analysis. In: BRENCHLEY, P.J. \& WILLIAMS, B.P.J. eds. Recent Developments and Applied Aspects. Oxford, The Geol.Soc. - Blackwell Scientific Publ. p.31-47.

ASSINE, M.L. 1993. O eólico e o fluvial na Formação Pirambóia. In: V SIMPÓSIO SULBRASILEIRO DE GEOLOGIA, V, Curitiba, PR. Boletim de Resumos e Programas, p.53-54.

BERTALANFFY, L.V. 1972. Historia y desarrollo de la teoría general de sistemas. In: Perspectivas en la Teoría General de Sistemas. Madrid, Alianza Universidad Ed., 1 ed.cast.,1979. p.137-156.

BIGARELLA, J.J. 1948. Contribuição ao estudo dos arenitos da série São Bento. In: Folhetim do Instituto de Geologia da Universidade do Paraná, Curitiba, 4 p.

BIGARELLA, J.J. E SALAMUNI, R., 1967. Some paleogeographic and paleotectonic features of the Paraná Basin. In: J.J. Bigarella, R.D. Becker e I.D. Pinto (Eds.), Problems in Brazilian Gondwana Geology, Curitiba, p. 235-301.

BIGARELLLA \& BECKER 1975. Correlative deposits. In: INTERNATIONAL SYMPOSIUM ON THE QUATERNARY, Curitiba. Topics for Discussion, X... Bol. Paranaense de Geoc., 33:225-230.

BIGARELLA, J.J. \& VAN EEDEN, O.R. 1970. Mesozoic paleowind patterns and the problem of continental drift. Bol. Paranaense de Geociências, 28/29:115-144.

BÓSIO, N.J. 1973. Geologia da Área de São Pedro, SP. Rio Claro, SP, Fac. Filos. Ciências e Letras. Tese de Doutoramento (inéd.). 125 p.

BROOKFIELD, M.E. 1977. The origin of bounding surfaces in ancient Aeolian sandstones. Sedimentology; (24) 303-332.

BRUUN, P. 1962. Sea level rise as a cause of shore erosion. Am.Soc.Civil Engin.Proc., J.Waterways Harbors Div., 88:117-130.

CABRAL JR., M.; MOTTA, J.F.M.; TANNO, L.C.; HELLMEISTER, Z.; COIMBRA, A.M. 1992. Revisão estratigráfica do nordeste do Estado de São Paulo. In: SIMPÓSIO SOBRE AS BACIAS CRETÁCICAS BRASILEIRAS, 2, Rio Claro. Resumos Expandidos. Rio Claro, UNESP, p.134-136.

CAETANO-CHANG, M.R. 1997. A Formação Pirambóia no Centro-Leste do Estado de São Paulo. Rio Claro, SP, Inst. Geoc. e Ciências Exatas, UNESP. Tese de LivreDocência (inéd.). 196 p. 
CAMPBELL, C.V. 1967. Lamina, laminaset, bed and bedset. Sedimentology, 8:7-26.

CARNEIRO, C.D.R. \& ALMEIDA, F.F.M. 1998. Botucatu: o grande deserto brasileiro. Ciência Hoje, 24(143): 37-43.

CARVALHO, C.H.G. \& GIANNINI, P.C.F. 1998. Morfodinâmica de draas costeiros e superfícies de truncamento na região de Imbituba-Jaguaruna, SC. In: CONGR. BRAS. GEOL., 40, Belo Horizonte, MG. Anais... Belo Horizonte, SBG. p.258.

CARVER, R.E. 1971. Heavy mineral separation. In: CARVER, R.E. ed. Procedures in Sedimentary Petrology. New York, Wiley -Interscience. p.427-452.

CHOQUETTE, P.W. \& PRAY, L.C. 1970. Geological nomenclature and classification of porosity in sedimentary carbonates. Am. Assoc. Petroleum Geologists, Bull., v.54, p.207-250.

COIMBRA, A.M.; BRANDT NETO, M.; COUTINHO, J.M.V. 1981. Silicificação dos Arenitos da Formação Bauru no Estado de São Paulo. In: A FORMAÇẢo BAURU NO ESTADO DE SÃO PAULO E REGIÕES ADJASCENTES, São Paulo. Coletânea de trabalhos e debates. São Paulo, SBG, P.103-115.

COIMBRA, A.M. \& GIANNINI, P.C.F. 1989. Estruturas e Fácies Sedimentares na Bacia do Paraná, Regiões de Vila Velha - Ponta Grossa-Castro-Tibaji (PR) e de Piraju Fartura - Taguaí (SP). Curitiba, Univ. Federal Paraná. Roteiro de Aula de Campo (inéd.). $41 \mathrm{p}$.

COMPANHIA DE PESQUISA DE RECURSOS MINERAIS - CPRM. 1980. Geologia do Bloco SF-22-W (ACS-48). São Paulo, CPRM, 85 p.

CORDANI, U.G. \& VANDOROS, P. 1967. Basaltic rocks of the Paraná Basin. In: BIGARELLA, J.J.; BECKER, R.D.; PINTO, J.D. ed. Problems in Brazilian Gondwana Geology. Curitiba, UFPR. p.207-231.

COWIE, J.W. \& BASSET, M.G. 1989. IUGS Global stratigraphic chart. Episodes, 12(2).

DE ROS, L.F. \& MORAES, M.A.S. 1984. Seqüência diagenética em arenitos: uma discussão inicial. In: CONGRESSO BRASILEIRO DE GEOLOGIA, 33, Rio de Janeiro, 1984. Anais. SBG, v.2, p. 894-904.

DELLA FAVERA,J.C. 1990. Tempestitos na Bacia do Parnaiba. Porto Alegre, Univ.Federal Rio Grande do Sul. Tese de Doutoramento (inéd.). 2v., 280p.

DELLA FAVERA,J.C. 1991. Fundamentos da estratigrafia moderna. Rio de Janeiro, Instituto de Geociências, Universidade do Estado do Rio de Janeiro. Notas de aula, $65 p$.

DICKINSON, W.R. 1970. Interpreting detrital modes of graywacke and arkose. Jour. Sedim. Petrol., 40(1/2): 695-707.

DICKINSON, W.R. \& Suczek, C.A. 1979. Plate tectonics and sandstone composition. Bull. Am.Assoc. Petrol. Geol. 63: 2164-2182.

DONATTI, L.M.; SAWAKUCHI, A.O.; GIANNINI, P.C.F.; FERNANDES, L.A. 2001. The Pirambóia-Botucatu succession in São Paulo and Paraná States: different eolian systems in the Paraná Basin. Anais da Acad. Bras. Ciências, em revisão.

DOTT, R.H., Jr. 1964. Wacke, graywacke and matrix - what approach to immature sandstone classification? J. Sediment. Petrol.,34(3):625-632. 
ERNESTO, M. \& PACCA, I.G. 1988. Paleomagnetism of the Paraná basin flood volcanics, southern Brazil. In: PICCIRILLO, E.M. \& MELFI, A.J., eds., The Mesozoic flood volcanism of the Paraná Basin. São Paulo, IAG/USP, p. 229-255.

FERNANDES, A.C.S. \& CARVALHO, I.S. 1990. Icnofósseis de invertebrados da Formação Botucatu, São Paulo (Brasil). Anais da Acad. Brasileira de Ciências, 62(1):45-49.

FERNANDES, L.A. 1992. A Cobertura Cretácica Suprabasáltica no Paraná e Pontal do Paranapanema (SP): os Grupos Bauru e Caiuá. São Paulo, Inst. Geoc. Univ. S.Paulo, Dissertação de Mestrado (inéd.). 129 p.

FERNANDES, L.A. 1998. Estratigrafia e evolução geológica da parte oriental da Bacia Bauru (Ks, Brasil). São Paulo, Inst. Geoc. Univ. S.Paulo, Tese de Doutoramento (inéd.) $216 \mathrm{p}$.

FERREIRA, R.P.D. 1979. Geomorfologia da Região da Serra do Limoeiro SP. Inst. de Geog. Univ. de S. Paulo. Tese de doutoramento, 152p.

FICHTER, L.S. 1988. Process-response modeling and the scientific process. J. Geol. Education, 36: 72-78.

FISHER, W.L. 1983. Facies Analysis in Reservoir Geology. Ouro Preto, Univ.Federal Ouro Preto. Apostila de Curso (inéd.). 66p.

FOLK, R.L. 1974. Petrology of Sedimentary Rocks. Texas, Hemphill Publishing Co., 182 p.

FREYBERGER, B.V. 1927. Observaciones geologicas en la región de las agatas de la serra Geral; Rio Grande do Sul. Bol. de la Academia Nac. de Ciencias en Cordoba, 30:129-170.

FRYBERGER, S.G. 1993. A review of Aeolian bounding surfaces, with examples from the Permian Minnelusa Formation, USA. North, C.P. \& Prosser, D.J. eds. 1993. Characterization of fluvial and Aeolian reservoirs. (Geological Society Special Publication $\mathrm{n}^{\circ}$ 73) p. 167-197.

FRYBERGER, S.G. \& SCHENK, C. 1988. Pin stripe lamination: a distictive feature of modern and ancient eolian sediments. Sedimentary Geol., 55(1/2):1-15.

FÚLFARO, V.J. 1972. The Paraná Basin Upper Permian and Lower Mesozoic stratigraphic succession. Anais da Academia Brasileira de Ciências, 44 (suplemento): 147-148.

FÚLFARO, V.J. \& BÓSIO, N.J. 1968. Novas observações sobre a faciologia do Arenito Botucatu no Estado de São Paulo. In: CONG. BRAS. GEOL., 22, Bol. Resumos... Belo Horizonte, SBG, p.57-59.

FÚLFARO, V.J. \& LANDIM, P.M.B. 1976. Stratigraphic sequences of the intracratonic Paraná Basin. Berlin-Stuttgart. Newsl. Stratigr., 4(3):150-168.

GALEHOUSE, J.S. 1971b. Sedimentation analysis. In: CARVER, R.E. ed. Procedures in Sedimentary Petrology. New York, Wiley-Interscience. p.69-94.

GIANNINI, P.C.F. 1993. Sistemas Deposicionais no Quaternário Costeiro entre Jaguaruna e Imbituba, SC. São Paulo, Inst. Geoc. Univ. S. Paulo. Tese de Doutoramento (inéd.) $2 v, 2$ mapas, 439p.

GIANNINI, P.C.F. 1998. Associações de fácies eólicas ativas na costa centro-sul de Santa Catarina. Anais da Acad. Bras. Ciências, 70(3): 696. 
GIANNINI, P.C.F. 2001. As formações Pirambóia e Botucatu nos estados de São Paulo e Paraná. São Paulo, Inst. Geoc. Univ. S.Paulo. Relatório final de pesquisa 143 p.

GIANNINI, P.C.F.; FERNANDES, L.A.; DONATTI, L.M.; SAWAKUCHI, A.O.; MORI, E.K.; COIMBRA, A.M. 2000. Paleowinds in the Pirambóia Formation, Perm-Triassic of the Paraná Basin. In: INTERNATIONAL GEOLOGICAL CONGRESS, 31 (aceito).

GIANNINI, P.C.F.; DONATTI, L.M.; FERNANDES, L.A.; FONSECA, P. L..; SAWAKUCHI, A. O.; RODRIGUES, S.O.; MORI, E. K. 1999a. Confronto entre o sistema eólico da costa sul-catarinense e as formações Pirambóia e Botucatu: correlações processoproduto do Quaternário no estudo de rochas mesozóicas. In: CONGR. ASSOC. BRASIL. DE ESTUDOS DO QUATERNÁRIO, 7, Porto Seguro, BA. Anais...disponível em meio digital (cd). Salvador, Abequa. $3 p$.

GIANNINI, P.C.F.; FERNANDES, L.A.; DONATTI, L.M; SAWAKUCHI, A.O.; MORI, E.K.; COIMBRA, A.M. 1999b. Rumos de paleoventos na Formação Pirambóia nos Estados de São Paulo e Paraná. In: SIMPÓSIO DE GEOLOGIA DO SUDESTE, 6, São Pedro, SP. Boletim de Resumos... São Pedro, SBG-SP/RJ/ES. p.72.

GIANNINI, P.C.F. \& SANTOS, E.R. 1994. Padrões de variação espacial e temporal na morfologia de dunas de orla costeira no centro-sul catarinense. Bol. Paranaense de Geoc. 42:73-95.

GIUSTI, D.; ROSA FILHO, E.F.; BITTENCOURT, A.V.L. 1996. Aqüífero Botucatu: a maior potencialidade hidrotermal dos países do Mercosul. In: CONGR. BRAS. TERMALISMO, 3, Gravatal, SC. Sessões Técnicas... Florianópolis, Soc. Bras. Termalismo, p.21-27.

GUIMARÃES NETTO, R. 2001. Icnologia e Estratigrafia de Seqüências. In: H.J.P.S. RIBEIRO (org.), Estratigrafia de Seqüências: Fundamentos e aplicações, 219-259.

HAVHOLM, K.G. \& KOCUREK, G. 1994. Factors controlling aeolian sequence stratigraphy: clues from super bounding surface features in the Middle Jurassic Page Sandstone. Sedimentology, 41(5): 913-934.

HUBERT, J.F. 1962. A zicon-tourmaline-rutile maturity index and the dependence of the composition of heavy mineral assemblages with the gross composition and texture of sandstones. Journal of Sedimentary Petrology. 32(3): 440-450.

INSTITUTO DE PESQUISAS TECNOLOGICAS DO ESTADO DE SÃO PAULO SIA. 1981. Mapeamento Geológico do Bloco SF-22-U (ACS-74). São Paulo. Relatório IPT, 15377. v.1.

KOCUREK,G. 1981. Significance of interdune deposits and bounding surfaces in eolian dune sands. Sedimentology, 28(6):753-780.

KOCUREK,G. 1988. First-order and super bounding surfaces in eolian sequences Bounding surfaces revisited. Sediment.Geol., 56(1/4):193-206.

KOCUREK, G. A. 1996. Deserts aeolian systems. In: READING, H.G. (ed.) Sedimentary Enviroments: Processes, Facies and Stratigraphy. Oxford, Blackwell Science, Cap. 5, $688 \mathrm{p}$.

KOCUREK, G. \& HAVHOLM, K.G. 1993. Eolian Sequence Stratigraphy - A Conceptual Framework. In: Siliciclastic Sequence Stratigraphy. AAPG Memoir 58, cap.16. p.393409. 
KRYNINE, P.D. 1948. Petrology and genesis of the Third Bradford sand. Bull. Pennsylvania State College, 29: 134p.

LAVINA, E.L. 1991. Geologia sedimentar e paleogeografia do Neopermiano e Eotriássico (Intervalo Kazaniano-Scythiano) da Bacia do Paraná. Porto Alegre. 332p., 2v. (Tese de Doutorado, IG-UFRGS).

LEINZ, V. 1938. A silicificação nos sedimentos gondwânicos no sul do Brasil e sua origem. Dep. Nac. da Prod. Mineral, publ. especial. Anais da Academia Brasileira de Ciênc., 10(3).

LEONARDI, G. \& SARGEANT, W.A.S. 1986. Footprints representing a new Mesozoic vertebrate fauna from Brazil. Modern Geology, 10(1):73-84.

LEONARDI, G. 1994. Annotated atlas of South America tetrapod footprints (Devonian to Holocene). Brasilia, Companhia de Pesquisa de Recursos Minerais, $246 \mathrm{p}$.

MAACK, R. 1947. Breves notícias sobre a geologia dos estados do Paraná e Santa Catarina. In: Arq. Biol. Tecn., Curitiba, 2:63-154.

MAACK, R. 1953. Mapa geológico do Estado do Paraná. 1:750.000. Inst. Biol. Pesq. Tec., Curitiba.

MANGE, M.A. \& MAURER, H.F.W. 1992. Heavy minerals in colour. London, Chapman \& Hall, $147 \mathrm{p}$.

MARTINI, J.E.J. 1982. Karst in Back Reef and Wolkberg Group quartzite of the eastern Transvaal escarpment. South Africa Bol. Soc. Venezolana Espel., 10(19): 99-114.

MATOS, S.L.F. 1995. O Contato entre o Grupo Passa Dois e a Formação Pirambóia na borda Leste da Bacia do Paraná no Estado de São Paulo. São Paulo. 110p. (Dissertação de Mestrado, IG-USP).

McKEE, E.D. \& WEIR,G.W. 1953. Terminology for stratification and cross stratification in sedimentary rocks. Bull.Geol.Soc.Am., 63(4):381-390.

MENDES, J.C. 1961. Algumas considerações sobre a estratigrafia da Bacia do Paraná. Bol.Paran.Geogr., 415:3-33.

MENDES, J.C. 1971. As camadas gonduânicas do Brasil e seus problemas. An. Acad. Bras. Ciências, 43:187-196.

MILANI, E.J. 1997. Evolução Tectono-Estratigráfica da Bacia do Paraná e seu Relacionamento com a Geodinâmica Fanerozóica do Gondwana Sul-Ocidental. Porto Alegre, RS. 2v. (Tese de Doutoramento, UFRGS).

MILANI, E.J. \& RAMOS, V. A. 1998. Orogenias paleozóicas no domínio sul-ocidental do Gondwana e os ciclos de subsidência da Bacia do Paraná. Rev. Bras. Geociênc, 28:473-484.

MINERAIS DO PARANÁ S/A-MINEROPAR. 1986. Mapa geológico do Estado do Paraná (escala 1:1.400.000). Governo do Estado do Paraná-Secretaria de Estado da Indústria e do Comércio, Curitiba.

MONTANHEIRO, T.J. 1999. Prospecção e Caracterização de Pozolanas na Bacia do Paraná, Estado de São Paulo. São Paulo, Inst. Geoc. Univ. S. Paulo. Tese de Doutoramento (inéd.), 226p. 
MORAES REGO, L.F. 1930. A geologia do petróleo no Estado de São Paulo. Bol. Serv. Geol. Mineralógico do Brasil, 46.

MORAES REGO, L.F. 1932. A Geologia do Estado de São Paulo. São Paulo, 153p. (separata do Boletim D.E.R.)

NISHIMURA, L. \& ZUQUETTE, L.V. 1994. A importância da cartografia geotécnica para caracterização de áreas de aqǘferos livres; exemplo do Aqüífero Botucatu na quadrícula de São Carlos, SP. Geociências, 13(2):345-357.

PARAGUASSU, A.B. 1968. Contribuição ao Estudo da Formação Botucatu - Sedimentos Aquosos, Estruturas Sedimentares e Silicificação. São Carlos, SP, Esc. Eng. Univ. S.Paulo. Tese de Doutoramento (inéd.), 131p.

PARAGUASSU, A. B. 1972. Experimental silicification of sandstone. Geol. Soc. Am. Bull. 83 (9):2853-2858.

PARFENOFF, A.; POMEROL, C.; TOURENQ, J. 1970. Les Minéraux en Grains : Methods d'etude et determination. Paris, Masson. 571p.

PETTIJOHN, F.J. 1957. Sedimentary Rocks. New York, Harper \& Row, Publ. 3ed., 1975. $628 \mathrm{p}$.

PETTIJOHN, F.J.; POTTER, P.E.; SIEVER, R. 1972. Sand and sandstone. Heidelberg, Springer-Verlag. $618 \mathrm{p}$.

POPPER, K.R. 1968. A lógica da pesquisa científica. São Paulo, Cultrix, 567p.

POPPER, K.R. 1972. Conjecturas e refutações. Brasília, Editora Universidade de Brasília, 450p.

POPPER, K.R. 1975. Conhecimento objetivo. São Paulo, Editora Itatiaia, 394p.

POWERS, M.C. 1953. A new roundness scale for sedimentary particles. Jour. Sedim.Petrol., 23:117-119.

PROMON ENGENHARIA S.A. 1980. Geologia do Bloco SG-22-C (ACF-76). Relatório Interno. São Paulo, Dezembro/1980.

RENNE, P.R. 1997. Geochronology of the Paraná-Etendeka Igneous Province. In: SouthAmerican Symposium on Isotope Geology, 1; São Paulo, 1997. Extend Abstracts. São Paulo, Brazil, p.20-23.

RICCOMINI, C.; GIMENEZ FILHO, A.; ALMEIDA, F.F.M. 1984. Consideraçōes sobre a estratigrafia do Permo-Triássico na região da Serra do Cadeado, Paraná. In: CONGRESSO BRASILEIRO DE GEOLOGIA, 33, 1984, Rio de Janeiro. Anais... Rio de Janeiro, SBG, v.2, p.754-763.

RICCOMINI,C. 1995. Tectonismo Gerador e Deformador dos Depósitos Sedimentares Pós-Gondvânicos da Porção Centro-Oriental do Estado de São Paulo e Áreas Vizinhas. São Paulo, Inst. Geoc. Univ. S.Paulo. Tese de Livre-Docência (inéd.), 100 p.

ROHN, R. 1994. Evolução Ambiental da Bacia do Paraná Durante o Neopermiano no Leste de Santa Catarina e do Paraná. São Paulo, Inst. Geoc. Univ. S.Paulo. Tese de Doutoramento (inéd.). 2v, 386p. 
ROSA F', E.F.; MONTANO, J.X.; AINCHIL, J.; GIUSTI, D.A.; MONASTIER, M.S.; FORLIN, M.; PAEGLE, J.. 1996. Projeto Sostenible del Acuifero Botucatu, Brasil. Curitiba, Intern. Devel. Research Center, UFPR, PR, Relatório Final (inédito). 37p.

SALAMUNI, R. \& BIGARELLA, J.J. 1967. The Botucatu Formation. In: BIGARELLA, J.J.; BECKER, R.D.; PINTO, J.D. eds. Problems in Brazilian Gondwana Geology. Curitiba, UFPR. p. 197-206.

SANFORD, R.M. \& LANGE, F.W. 1960. Basin study approach to evolution of Parana miogeosynclines of South Brazil. Bull.Am. Assoc. Petrol. Geologists, 44(8):1316-1370.

SAWAKUCHI, A.O. 2000. Dinâmica e contexto paleogeográfico do sistema deposicional eólico Pirambóia no Estado de São Paulo. São Paulo, Inst. Geoc. Univ. S. Paulo. Trabalho de Formatura, 38p., 11 anexos, 14 fotos.

SCHNEIDER, R.L.; MÜHLMANN, H.; TOMMASI, ; MEDEIROS, R.A.; DAEMON, R.F. \& NOGUEIRA, A.A. 1974. Revisão estratigráfica da Bacia do Paraná. In: CONG. BRAS. GEOL., 28, Porto Alegre, SBG, 1974. Anais..., v.1, p.41-64.

SGARBI, G.N.C. 1997. Aspectos Paleogeográficos e Sedimentológicos do Mesozóico no Oeste do Estado de Minas Gerais. Instituto de Geociências, Universidade de Brasilia, Brasilia, Tese de Doutoramento, 224p. (inédito).

SOARES, P.C. 1973. O Mesozóico Gondwânico no Estado de São Paulo. Rio Claro, SP Fac.Filos.Ciências e Letras. Tese de Doutoramento (inéd.). $153 \mathrm{p}$.

SOARES, P.C. 1975. Divisão estratigráfica do Mesozóico do Estado de São Paulo. Rev.Bras.Geociências, 5:229-251.

SOARES, P.C. 1987. Seqüências tecto-sedimentares e tectônica deformadora no centroleste do Escudo Paranaense. Anais do III Simp. Sul-Brasileiro de Geologia. Curitiba, v. 2: 743-771.

SOARES, P.C. 1992. Tectônica Sinsedimentar Cíclica na Bacia do Paraná - Controles. Curitiba, Dpto.Geologia Univ. Fed. Paraná. Tese Prof.Titular (inéd.).131p.

SOARES, P.C. \& ASSINE, M.L. 1992. A seqüência Triássico-Jurássica da Bacia do Paraná. Acta Geologica Leopoldensia 36 (Estudos Tecnológicos 15):137-139.

SOARES, P.C. \& LANDIM, P.M.B. 1973. Aspectos regionais da estratigrafia da Bacia do Paraná no seu flanco nordeste. In: CONGRESSO BRASILEIRO DE GEOLOGIA, 27, Aracajú. Anais. Aracajú, SBG, v.1, p.243-256.

SOUZA, A.; SINELLI, O.; GONÇALUS, M.M. 1971. Nova ocorrência fossilifera na Formação Botucatu. In: CONGRESSO BRASILEIRO DE GEOLOGIA, 25, 1971, São Paulo. Anais... São Paulo, SBG, 1971, v.2, p. 281-295.

SUGUIO, K. \& COIMBRA, A.M. 1972. Madeira silicificada na Formação Botucatu. Ciência e Cultura, 24(11): 1049-1055.

SUGUIO, K.; COIMBRA, A.M.; GUARDADO, L.R. 1974. Correlação sedimentológica de arenitos da Bacia do Paraná. Bol. IG-USP, 5:85-116.

TURNER, S; REGELOUS, M; KELLEY, S; HAWKSWORTH, C; MANTOVANI, M. 1994. Magmatism and continental break-upin the South Atlantic: high precision ${ }^{40} \mathrm{Ar}-{ }^{39} \mathrm{Ar}$ geochronology. Earth Planet. Sci. Lett., 124:333-348.

VIEIRA, A.J. 1973. Geologia do centro e nordeste do Paraná e Centro-Sul de São Paulo. In: CONG. BRAS. GEOL., 27, Aracaju, SBG, 1973. Anais..., v.3, p.259-277. 
VIEIRA, A. J. \& MAINGUÉ, E. 1973. Geologia de Semi-Detalhe do Centro e Nordeste do Paraná e Centro-Sul de São Paulo. Ponta Grossa, Petrobras/Desul, 49p (Relatório Petrobras/Desul, 425).

WALKER, R.G. 1976. Facies and facies models. General introduction. In: WALKER, R.G. ed. Facies Models. Toronto, Geoc. Canada,1979, p.17. (Reprint Series, 1).

WALKER, R.G. \& MIDDLETON, G.V. 1977. Eolian sands. In: WALKER, R.G. ed. Facies Models. Toronto, Geosc. Canada, 1979, p.33-41. (Reprint Series,1).

WASHBURNE, C.W. 1930. Geologia do petróleo no Estado de São Paulo. Bol.Com.Geogr.Geol.Est.S.Paulo, 22:1-282.

WELTON, J.E. 1984. SEM Petrology Atlas. Tulsa, Oklahoma, AAPG. 237 p. (Methods in Exploration Series).

WERNICK, E. 1966. A silicificação do Arenito Botucatu na quadrícula de Rio Claro. Bol. Soc. Bras. Geologia, 15(1): 49-57.

WU, F.T. 1981. Minerais Pesados das Sequêencias Arenosas Paleozóica e Mesozóica no Centro-Leste do Estado de São Paulo. São Paulo, Inst. Geoc. Univ. S.Paulo. Dissertação de Mestrado, $79 \mathrm{p}$.

WU, F.T. \& CAETANO-CHANG, M.R. 1992. Estudo mineralógico dos arenitos das formações Pirambóia e Botucatu no centro-leste do Estado de São Paulo. Revista do Instituto Geológico, 13(1):56-68.

WU, F.T. \& SOARES, P.C. 1974. Minerais Pesados nas Formações Pirambóia e Botucatu. . In: CONG. BRAS. GEOL., 28, Porto Alegre, SBG, 1974. Anais..., v.1, p. 119-127.

ZALÁN, P.V.; WOLF, S.; CONCEIÇÃO, J.C.; ASTOLFI, A.M.; VIEIRA, I.S.; APPI, V.T.; ZANOTTO, O.A.; MARQUES, A. 1991. Tectonics and sedimentation of the Paraná Basin. In: ULBRICH, H.H.G.J. \& ROCHA-CAMPOS, A.C. eds. Gondwana Seven. São Paulo, Inst. Geoc. Univ. S. Paulo, p.83-117. 


$$
\text { ANEXOS }
$$




\begin{tabular}{|c|c|c|c|}
\hline PT.02 & 7290099 & 444326 & PT.02c \\
\hline PT.03 & 7290219 & 443346 & PT.03c \\
\hline RP.01 & 7406966 & 575662 & -- \\
\hline RP.02 & 7407390 & 573558 & - \\
\hline RP.03 & 7408242 & 573106 & -- \\
\hline RP.04 & 7407962 & 570884 & -- \\
\hline RP.05 & 7408491 & 568052 & -- \\
\hline RP.06 & 7408547 & 567684 & -- \\
\hline RP.07 & 7408729 & 567558 & -- \\
\hline RP.08 & 7411099 & 568324 & -- \\
\hline RP.09 & 7410882 & 568413 & -- \\
\hline SA.01 & 7422512 & 595131 & -- \\
\hline SA.02 & 7418423 & 586055 & SA.02c \\
\hline SA.02 & 7418423 & 586055 & SA.02h \\
\hline SA.03 & 7416273 & 577763 & SA.03ct \\
\hline SA.03 & 7416273 & 577763 & SA.03c \\
\hline SA.03 & 7416273 & 577763 & SA.03h \\
\hline SA.03 & 7416273 & 577763 & SA.03cb \\
\hline SA.04 & 7417163 & 580399 & SA.04 \\
\hline SA.04 & 7417163 & 580399 & SA.04ct \\
\hline SA.05 & 7424440 & 595215 & -- \\
\hline SA.06 & 7421984 & 592554 & -- \\
\hline SA.07 & 7426062 & 585577 & -- \\
\hline SA.08 & 7426232 & 582820 & -- \\
\hline SA.09 & 7424519 & 586239 & -- \\
\hline SA.10 & 7421716 & 589448 & SA.10t \\
\hline
\end{tabular}

\begin{tabular}{|c|c|c|c|}
\hline SA.11 & 7420220 & 586989 & - \\
\hline SA.12 & 7419739 & 586109 & -- \\
\hline SA.13 & 7419472 & 586167 & SA.13c \\
\hline SA.14 & próximo pto. & cerca de & SA.14c \\
\hline SA.15 & 7425128 & 594633 & SA.15c \\
\hline SA.15 & 7425128 & 594633 & SA.15h \\
\hline SA.16 & 7424160 & 594029 & SA.16h \\
\hline SA.17 & 7424326 & 593659 & -- \\
\hline SA.18 & 7422526 & 592868 & -- \\
\hline SA.19 & 7423119 & 591343 & SA.19c \\
\hline SA.20 & 7422333 & 591778 & - \\
\hline SA.21 & 7421356 & 601566 & SA.21t \\
\hline SA.22 & 7421652 & 601509 & SA.22t \\
\hline SA.23 & 7423420 & 601517 & - \\
\hline UV.01 & 7096658 & 489224 & SC.01b \\
\hline UV.01 & 7096658 & 489224 & SC.01c \\
\hline UV.02 & 7097251 & 485552 & PR.02r1 \\
\hline UV.02 & 7097251 & 485552 & PR.02r2 \\
\hline UV.02 & 7097251 & 485552 & PR.02r2 \\
\hline UV.02 & 7097251 & 485552 & PR.02c \\
\hline UV.02 & 7097251 & 485552 & PR.021 \\
\hline UV.03 & 7098928 & 487168 &.-- \\
\hline UV.04 & 7098822 & 485881 & -- \\
\hline UV.05 & 7102313 & 490733 & --- \\
\hline UV.06 & 7103553 & 502677 & -- \\
\hline & & & \\
\hline
\end{tabular}

Tabela 01 - Localização, em coordenadas UTM, dos pontos de afloramento descritos e a nomenclatura atribuída às amostras.

T3628

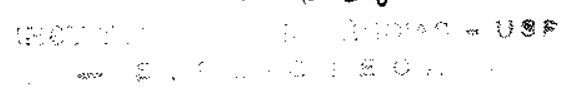




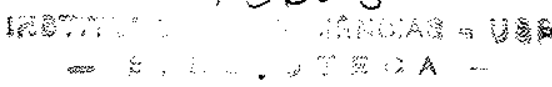

\begin{tabular}{|c|c|c|c|}
\hline Ponto & $\begin{array}{c}\text { Latitude } \\
\text { (UTM) }\end{array}$ & $\begin{array}{c}\text { Longitude } \\
\text { (UTM) }\end{array}$ & $\begin{array}{c}\begin{array}{c}\text { Amostras } \\
\text { (cód. campo) }\end{array} \\
\end{array}$ \\
\hline CA. 01 & 7430284 & 598530 & --- \\
\hline CB. 01 & 7287483 & 456715 & CB.01 \\
\hline CB. 02 & 7288450 & 451659 & CB. 02 \\
\hline GR.08 & 7200361 & 481203 & $\cdots$ \\
\hline GR.09 & 7199157 & 480535 & PR-09c \\
\hline GR.09 & 7199157 & 480535 & PR-09h \\
\hline GR.10 & 7199582 & 480407 & PR-10 \\
\hline GR.11 & 7199836 & 480392 & PR-11c \\
\hline GR.11 & 7199836 & 480392 & PR-11h \\
\hline GR.12 & 7199157 & 481097 & $\cdots$ \\
\hline GR.13 & 7200037 & 480076 & PR-13c \\
\hline GR.14 & 7200282 & 479641 & PR-14ct \\
\hline GR.14 & 7200282 & 479641 & PR-14cB \\
\hline IP. 01 & 7433332 & 631378 & IP.01he \\
\hline IP.01 & 7433332 & 631378 & IP. $01 \mathrm{hp}$ \\
\hline IR.07 & 7202840 & 487077 & -- \\
\hline IV.01 & 7290486 & 445919 & IV.01cs \\
\hline IV.02 & 7292164 & 447656 & $\cdots$ \\
\hline IV.11 & 7290307 & 445762 & PT.01c \\
\hline IV.03 & 7291396 & 447240 & IV. $03 \mathrm{c}$ \\
\hline IV.03 & 7291396 & 447240 & IV. $03 \mathrm{~h}$ \\
\hline IV.04 & 7292197 & 447518 & - \\
\hline IV.05 & 7292264 & 447104 & IV.05h \\
\hline IV. 05 & 7292264 & 447104 & IV.05c \\
\hline IV.06 & 7292504 & 447241 & -- \\
\hline IV. 07 & 7293552 & 447628 & - \\
\hline IV.08 & 7293876 & 448301 & -- \\
\hline IV.09 & 7291645 & 446938 & IV. $09^{\prime}$ \\
\hline IV.09 & 7291645 & 446938 & IV.09 \\
\hline IV. 10 & 7290488 & 444764 & $=$ \\
\hline $\mathrm{JC} .01$ & 7453272 & 611252 & JC.01h \\
\hline JC. 02 & 7439569 & 607143 & $-\cdots$ \\
\hline JC.03 & 7433906 & 624496 & IC. $.03 \mathrm{~V}$ \\
\hline JC.03 & 7433906 & 624496 & $\mathrm{JC} .03 \mathrm{~b}$ \\
\hline JC. 04 & 7436411 & 604649 & -- \\
\hline
\end{tabular}

\begin{tabular}{|c|c|c|c|}
\hline JC.05 & 7437459 & 606252 & JC.05 \\
\hline JC.06 & 7436023 & 617650 & JC.06h \\
\hline JC.06b & 7444913 & 628771 &.-- \\
\hline JC.07 & $300 \mathrm{~m}$ JC.06b & $300 \mathrm{~m}$ & JC.07 \\
\hline JC.07 & $300 \mathrm{~m}$ JC.06b & $300 \mathrm{~m}$ & JC.07c \\
\hline JC. 08 & 7442997 & 627872 & JC.08 \\
\hline JC.09 & 7442098 & 627878 & -- \\
\hline JC.09b & 7439022 & 626198 & \\
\hline JC.10 & 7433784 & 624069 & JC.10en \\
\hline JC.10 & 7433784 & 624069 & JC.10vi \\
\hline JC. 11 & 7434435 & 623407 & JC.11h \\
\hline JC.11 & 7434435 & 623407 & JC.11en \\
\hline JC.12 & 7435671 & 618983 & JC.12a \\
\hline JC.12 & 7435671 & 618983 & JC.12b \\
\hline JT.01 & 7423626 & 602399 & -- \\
\hline JT.02 & $1 \mathrm{~km}$ do pto & ant. por & -- \\
\hline JT.03 & 7424375 & 602480 & JT.03s \\
\hline JT.03 & 7424375 & 602480 & JT.03 \\
\hline JT.04 & 7424046 & 602389 & JT.04 \\
\hline MS.01 & 7354822 & 478552 & MS.01c \\
\hline MS.02 & 7354732 & 481967 & -- \\
\hline MS.03 & 7353189 & 483034 & MS.03c \\
\hline MS.04 & 7352807 & 483388 & MS.04c \\
\hline MS.05 & 7353140 & 483822 & MS.05c1 \\
\hline MS.05 & 7353140 & 483822 & MS.05c2 \\
\hline MS.06 & 7352736 & 485359 & MS.06c \\
\hline MS.06 & 7352736 & 485359 & MS.06h \\
\hline MS.06 & 7352736 & 485359 & MS.06h2 \\
\hline MS.07 & 7353091 & 484063 & MS.07ca \\
\hline MS.07 & 7353091 & 484063 & MS.07cf \\
\hline MS.07 & 7353091 & 484063 & MS.07c \\
\hline MS.08 & 7352371 & 487720 & -- \\
\hline MS.09 & 7347149 & 486736 & MS.09c \\
\hline MS.10 & 7346817 & 487096 & MS.10 \\
\hline MS.11 & 7346699 & 487382 & MS.11c \\
\hline MS.12 & 7347855 & 488798 & MS.12a \\
\hline MS.12 & 7347855 & 488798 & MS.12h \\
\hline MS.12 & 7347855 & 488798 & MS.12c \\
\hline
\end{tabular}


ANEXO 2

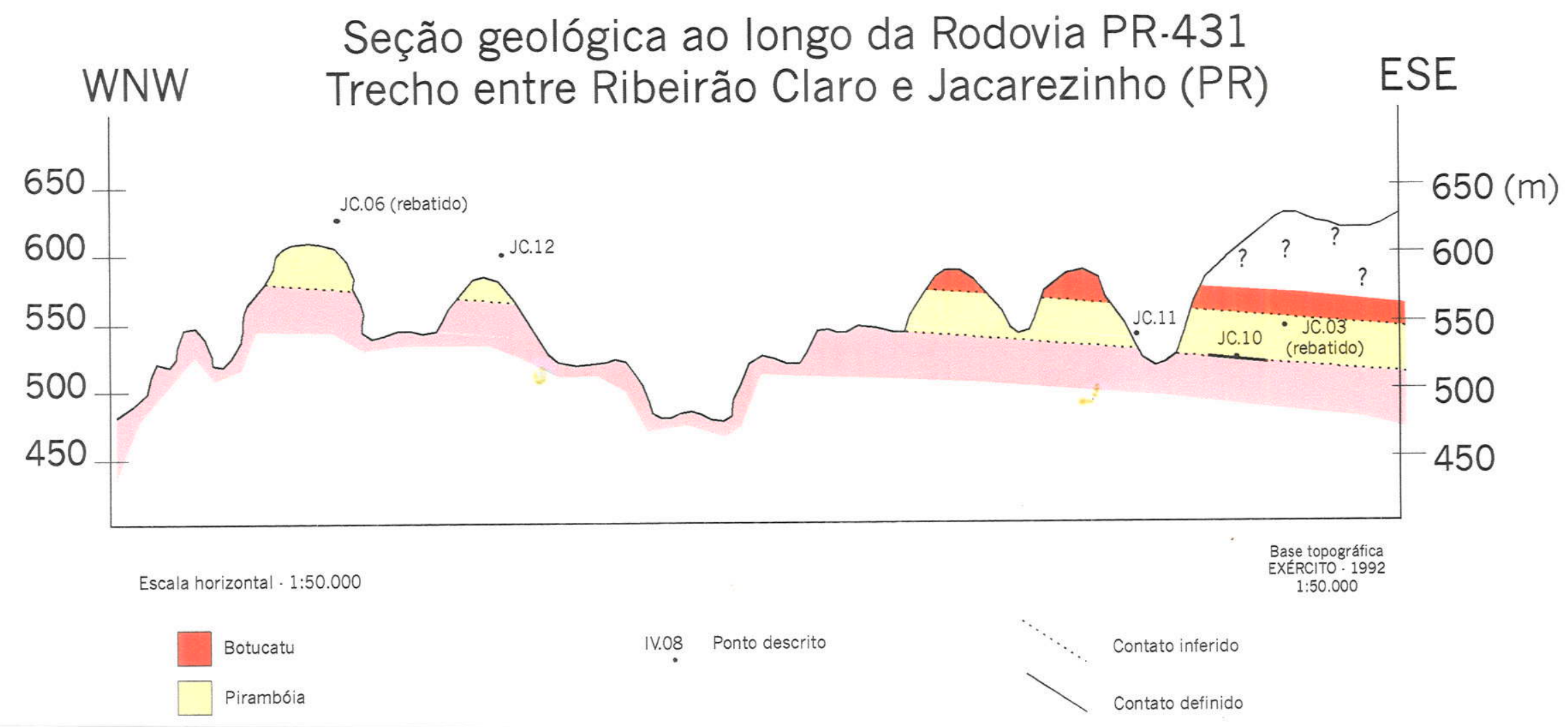


ANEXO 3

Seção geológica ao longo da Rodovia BR-153 Trecho sul das folhas topográficas Cambará e Jacarezinho (PR)

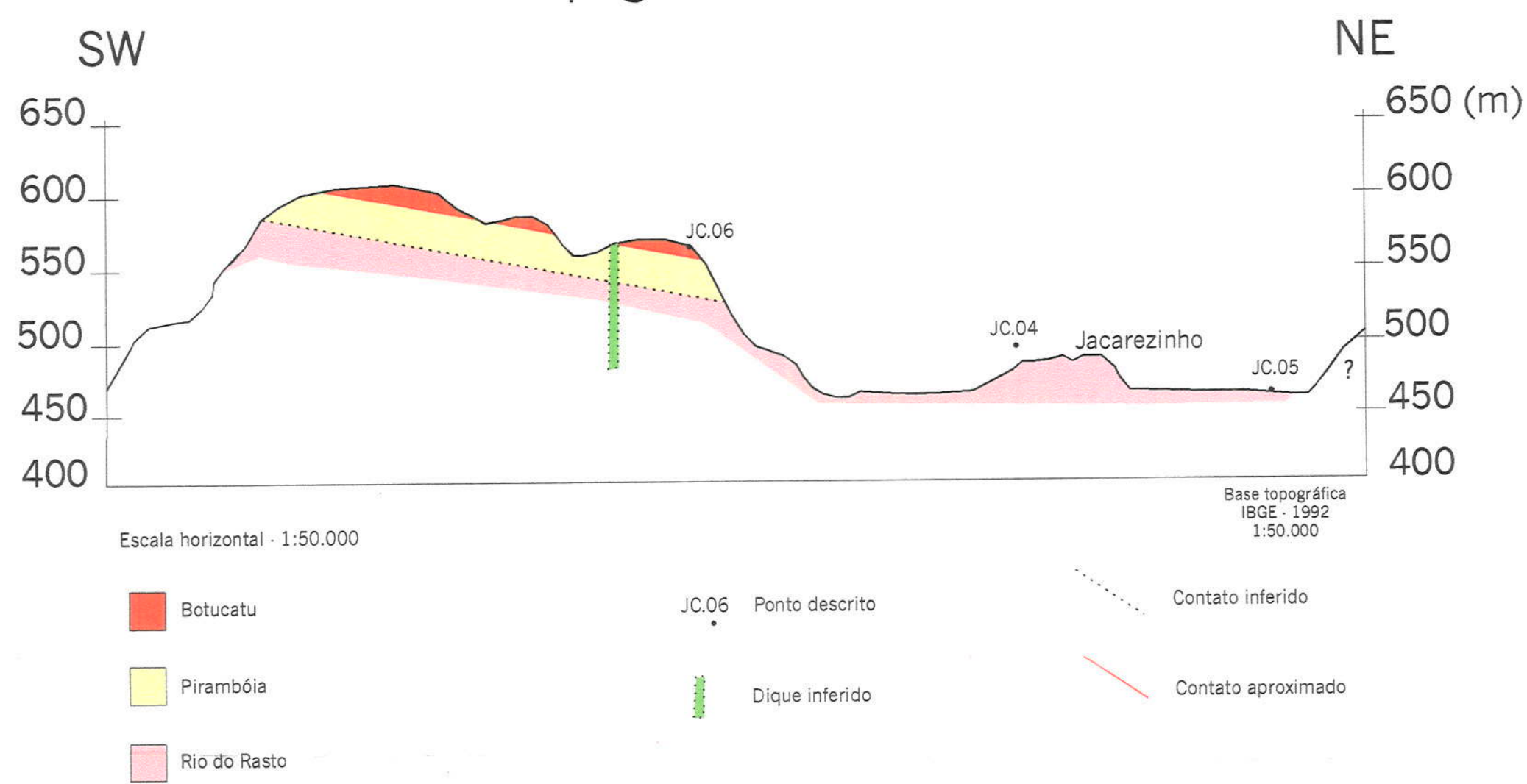




\section{ANEXO 4}

Seção geológica ao longo das Rodovias BR-153 e PR-439

Trecho entre Ribeirão do Pinhal e Santo Antônio da Platina (PR)

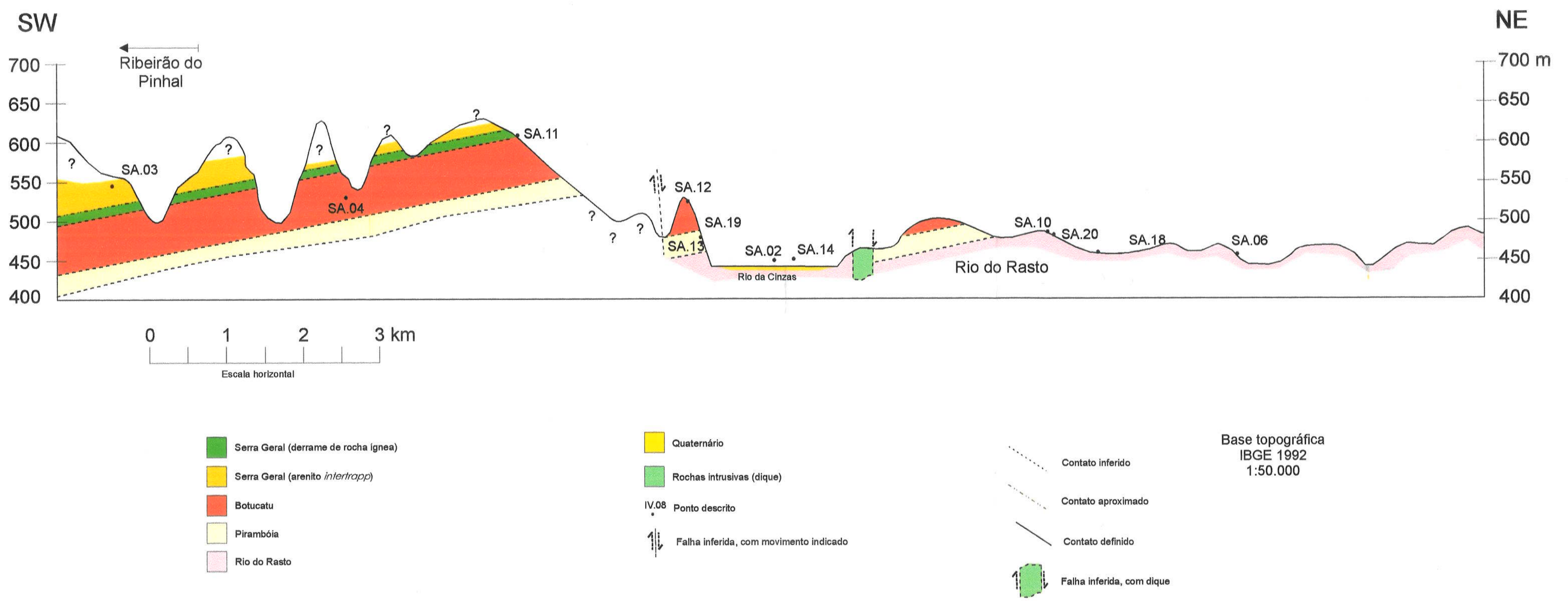


ANEXO 5

Seção geológica ao longo da Rodovia BR-376 Trecho entre Mauá da Serra e Ortigueira (PR)

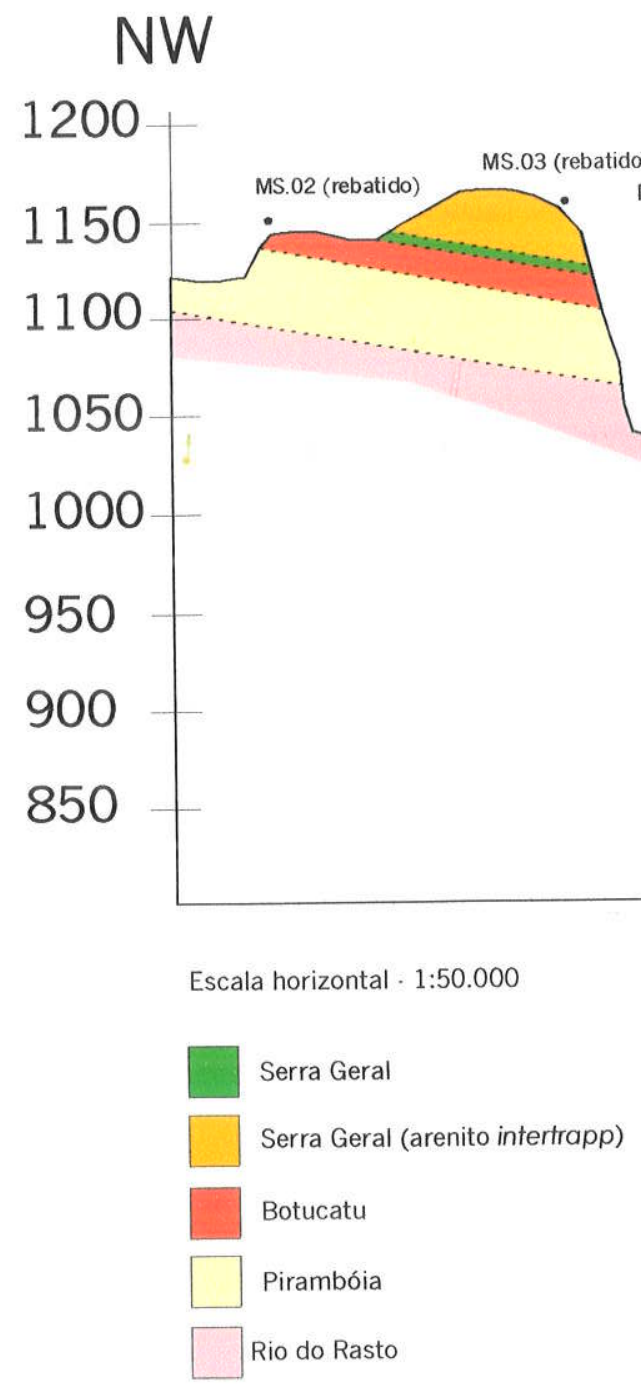

MS.10 Ponto descrito

Contato inferido

$\sqrt{1} 1 \mathrm{~V}$ Horst de pequeno rejeito

SE

$1200(n$ 
ANEXO 6

Seção geológica ao longo da Rodovia BR-466 $\mathrm{SW}^{\text {Trecho entre Pitanga e Ivaiporã (PR) }}{ }_{\mathrm{NE}}$

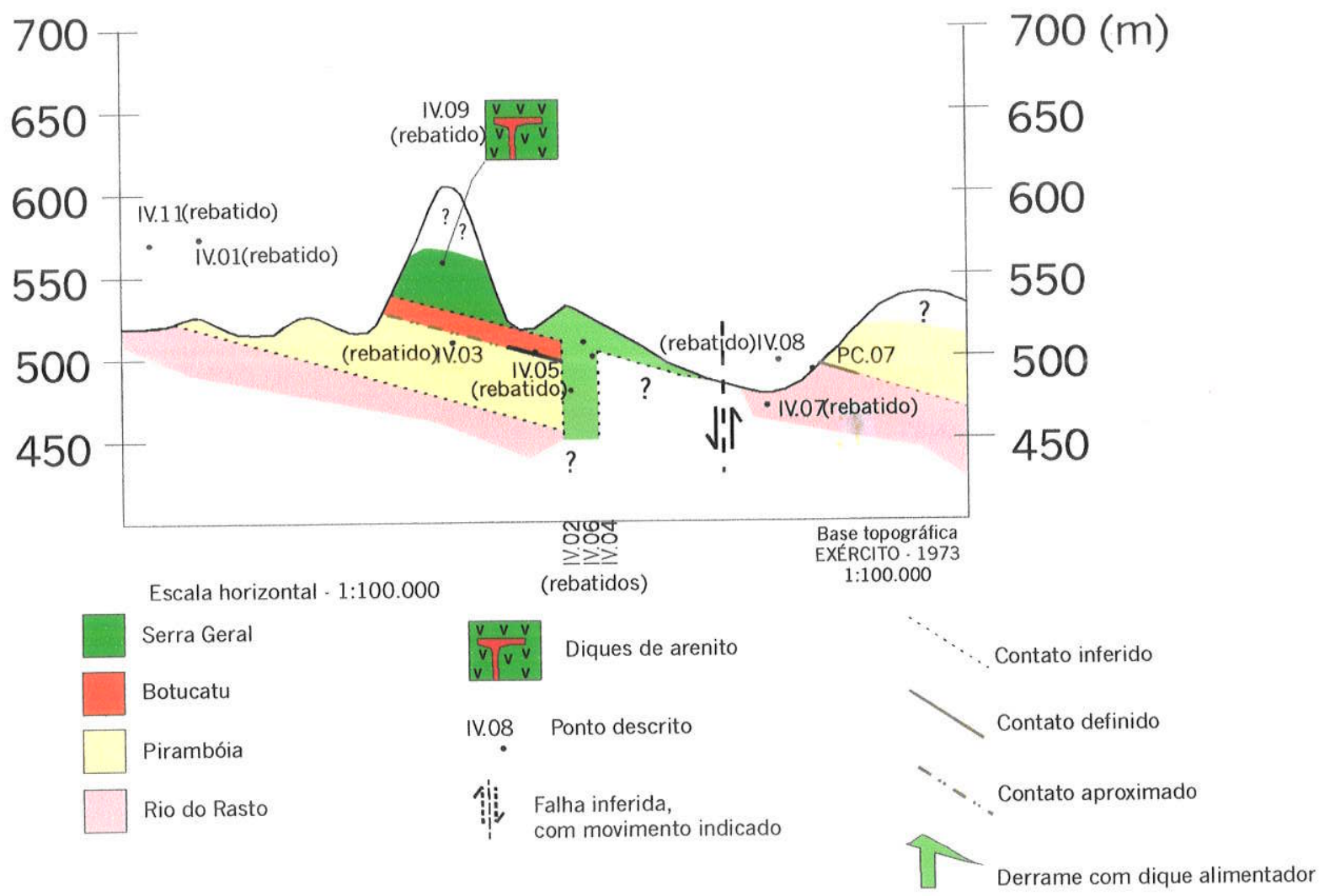




\section{ANEXO 7}

Seção geológica ao longo da rodovia entre Manuel Ribas e Cândido de Abreu (PR)

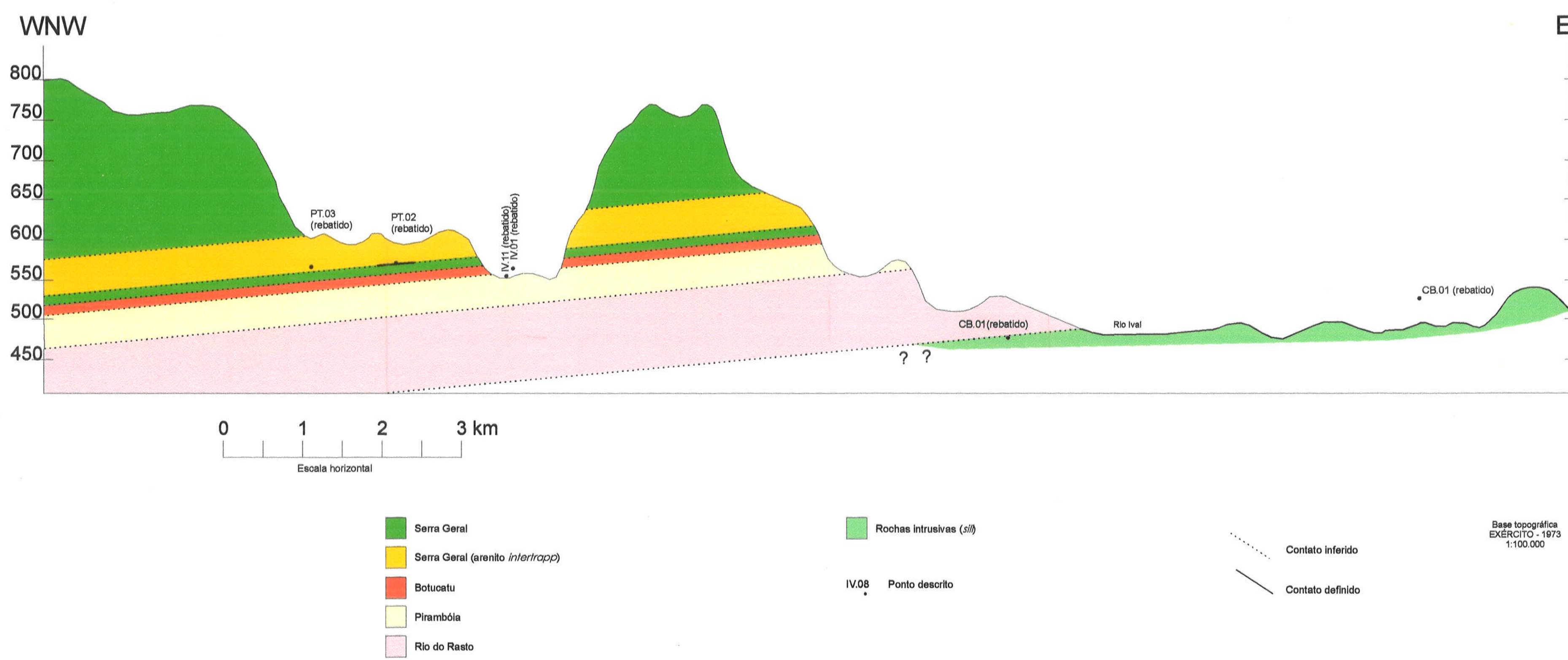




\section{ANEXO 8}

Seção geológica ao longo das Rodovias BR-373 e BR-277 Trecho entre Guarapuava e Relógio (PR)

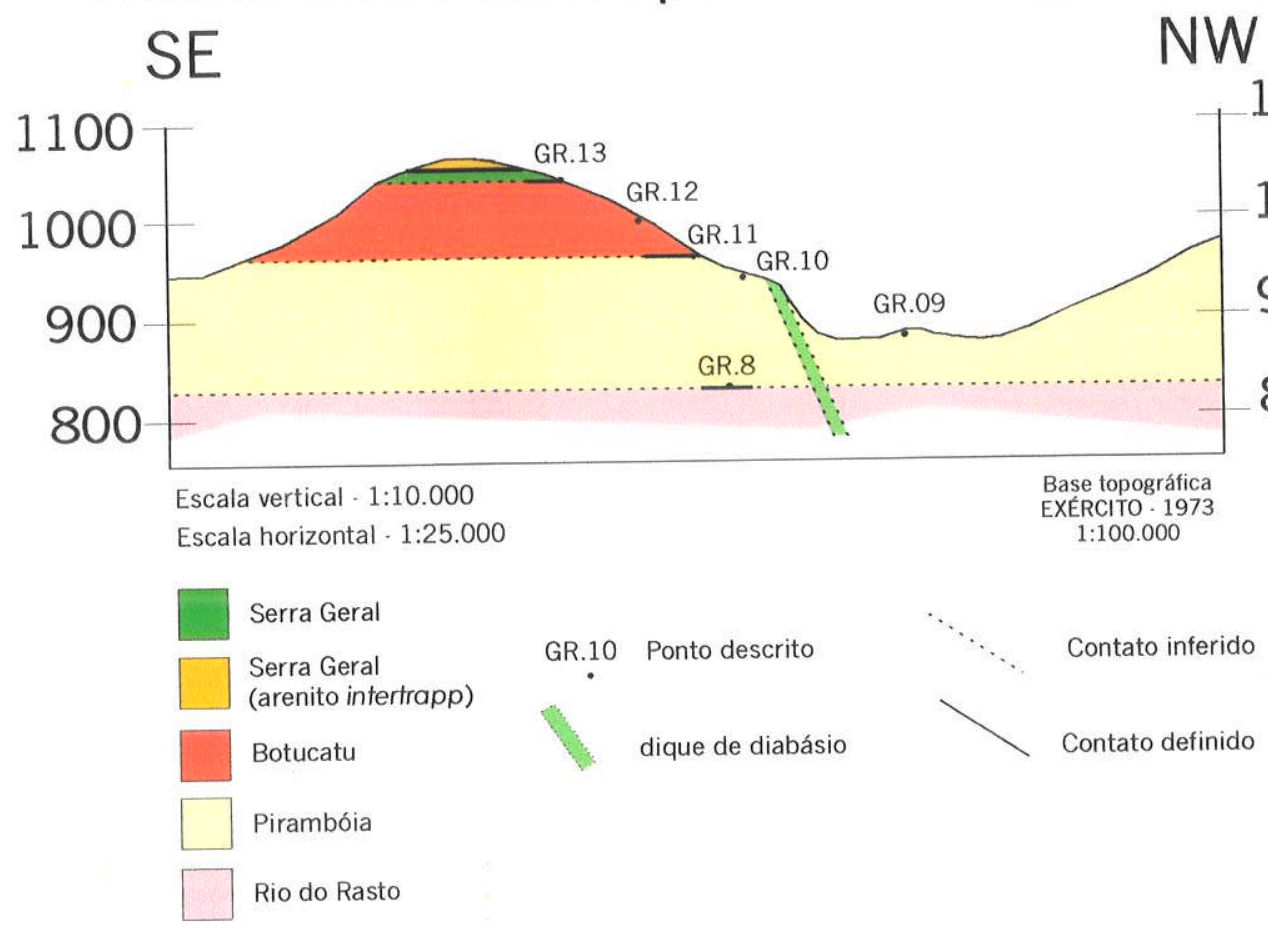

$1100(\mathrm{~m})$

1000

900

800 
ANEXO 9

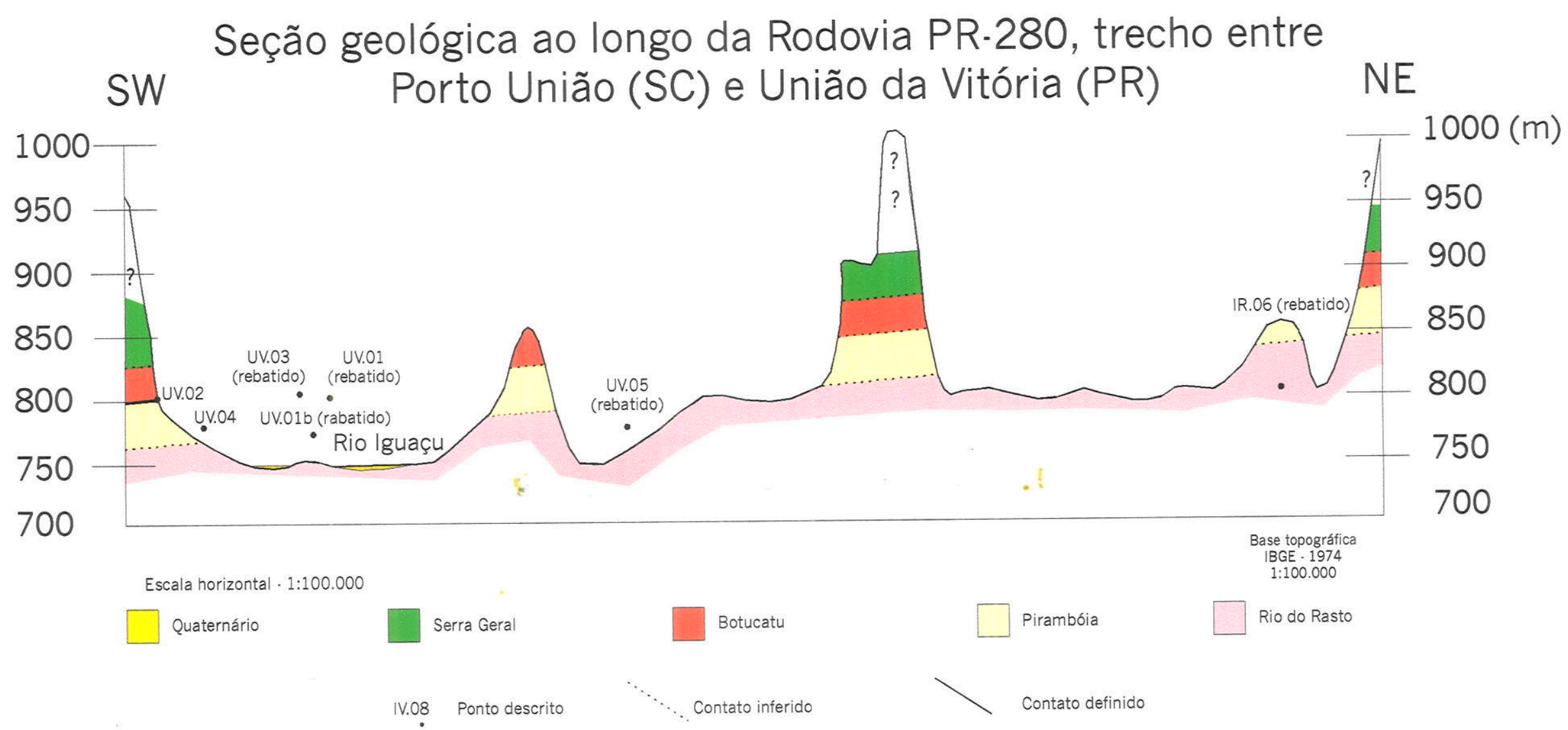




\section{Estruturas sedimentares}

Laminação cruzada com truncamento côncavo-convexo

Estratificação plano paralela

Estratos com deformação hidroplástica

Séries submétricas de estratificação cruzada acanalada

$\underline{-}=\quad$ Lentes centimétricas de silte

$\approx \approx \approx$

Laminação heterolítica do tipo wavy

Séries submétricas de estratificação cruzada acanalada com seixos nas superfícies migrantes (slipfaces)

$\therefore \therefore \quad$ Acamamento de aspecto maciço

Séries submétricas de estratificação cruzada acanalada

Acamamento intensamente bioturbado

(Provavelmente bioturbado)

Camada de argila com estrutura em chama

${ }_{\Delta}^{\Delta} \Delta \Delta \Delta \quad$ Intraclastos centimétricos de silexito

$\approx \quad$ Lâminas de argila contorcidas

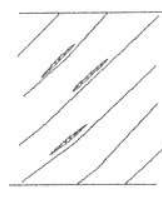

Séries métricas de estratificação cruzada acanalada com laminação transladante subcrítica

Icnofósseis do gênero Muensteria

Nível de grânulos (lag)

" \|\|$_{\|} \| \quad$ Icnofósseis sem gênero identificado

\section{Contatos entre fácies}

Contato planar, concordante

Contato erosivo

Contato irregular concordante - sobrecarga
Parâmetros estatísticos das rosáceas

$\mathrm{N}$ - Número de medidas

$\mathrm{PMx}$ - Percentagem máxima

PMd - Percentagem média

DV - Desvio padrão 


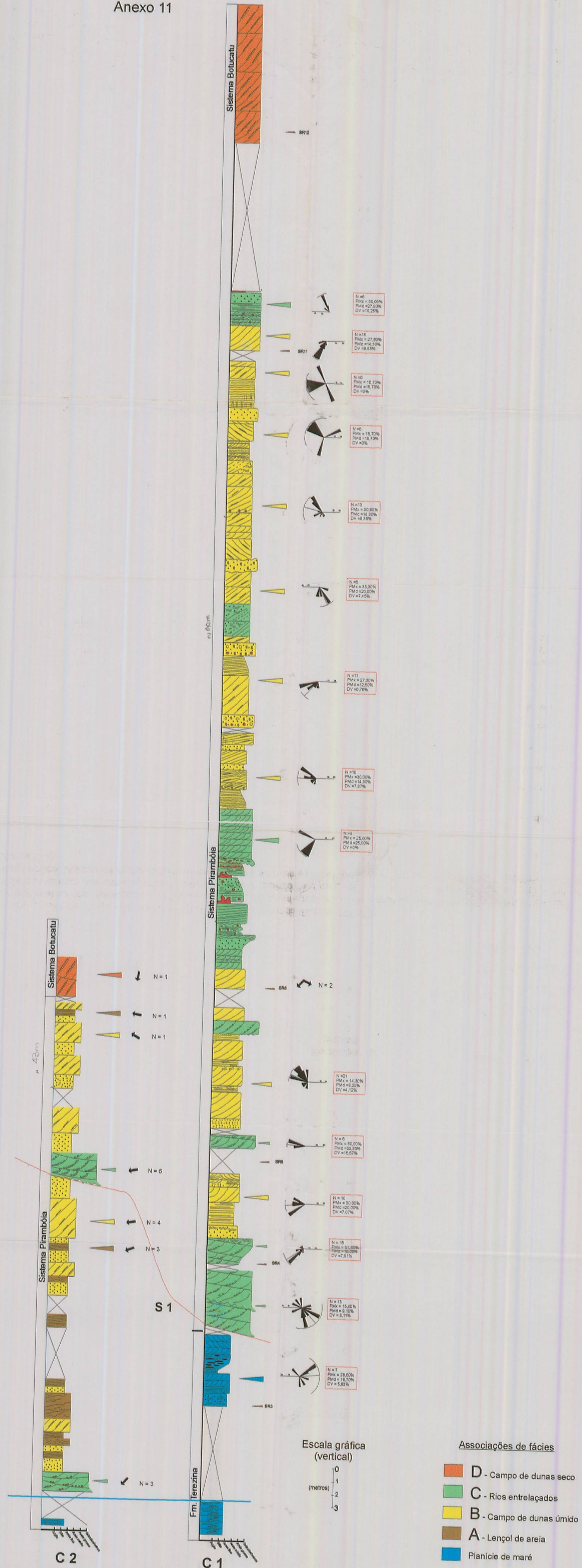

As seções apresentam o postas, elaboradas nas regiōes de Piraju - Sarutaiá, SP, (C1), Santo Antônio da Platina, PR (C2)

planícies interdunares inundadas, C) planície aluvial com rios entrelaçados e dunas eóliças de areia em planície de maré, B) campo de dunas incipientes com 